\title{
Condomínio Vanguarda: luta e resistência no centro de
}

\section{Santos-SP}

Versão Corrigida

\section{Bruna Garcia Eskinazi}

Dissertação apresentada ao Programa de Pós-Graduação em Geografia Humana do Departamento de Geografia da

Faculdade de Filosofia, Letras e Ciências Humanas da Universidade de São Paulo para a obtenção do título de Mestre em Geografia

Linha de Pesquisa: Geografia da Cidade e do Urbano

Orientadora: Prof ${ }^{a}$ Dra. Silvana Maria Pintaudi

São Paulo 
Autorizo a reprodução e divulgação total ou parcial deste trabalho, por qualquer meio convencional ou eletrônico, para fins de estudo e pesquisa, desde que citada a fonte.

Catalogação na Publicação Serviço de Biblioteca e Documentação

Faculdade de Filosofia, Letras e Ciências Humanas da Universidade de São Paulo

\begin{tabular}{|c|c|}
\hline \multirow[t]{3}{*}{ Ec } & $\begin{array}{l}\text { Eskinazi, Bruna Garcia } \\
\text { Condominio Vanguarda: luta e resistência no centro } \\
\text { de Santos-SP / Bruna Garcia Eskinazi ; orientadora } \\
\text { Silvana Maria Pintaudi. - Săo Paulo, 2018. } \\
\quad 160 \mathrm{f} \text {. }\end{array}$ \\
\hline & $\begin{array}{l}\text { Dissertaçăo (Mestrado) - Faculdade de Filosofia, } \\
\text { Letras e Ciências Humanas da Universidade de São } \\
\text { Paulo. Departamento de Geografia. Area de } \\
\text { concentraçăo: Geografia Humana. }\end{array}$ \\
\hline & $\begin{array}{l}\text { 1. cortiço. 2. habitaçăo de interesse social. } 3 \text {. } \\
\text { patrimônio histórico. } 4 \text {. gentrificaçăo. } 5 \text {. resistểncia. } \\
\text { I. Pintaudi, Silvana Maria, orient. II. Título. }\end{array}$ \\
\hline
\end{tabular}


Nome: Bruna Garcia Eskinazi

Título: Condomínio Vanguarda: luta e resistência no centro de Santos-SP

Dissertação apresentada ao Programa de PósGraduação em Geografia Humana do Departamento de Geografia da Faculdade de Filosofia, Letras e Ciências Humanas da Universidade de São Paulo para a obtenção do título de Mestre em Geografia 
Dedico este trabalho a todas e todos que lutam pelo direito à moradia e pelo direito à cidade.

À Josepha Gonçales Garcia. 


\section{AGRADECIMENTOS}

Muito obrigada a todos os membros da Associação dos Moradores dos Cortiços do Centro por abrirem suas portas e compartilharem as suas histórias comigo e possibilitarem este trabalho. Obrigada à Nay, Samara, Maria de Lourdes e Joaquina pelos depoimentos e pela receptividade. Obrigada aos moradores dos cortiços por abrerirem suas casas e responderem às questões.

Agradeço a minha mãe por todo apoio e incentivo durante o mestrado. A Francisco, pelo companherismo, mesmo que à distância.

Obrigada a prof ${ }^{a}$ Dra. Silvana Pintaudi pelas leituras, discussões e ensinamentos tão fundamentais para a construção deste trabalho e para meu aprendizado pessoal. Meus agradecimentos às professoras Dra. Ana Fani Alessandri Carlos, Dra. Isabel Alvarez e Dra. Simone Scifoni, em cujas disciplinas, as leituras e os debates com os colegas do PPGH foram importantíssimas e instigantes.

Agradeço a Lílian pela revisão deste trabalho. A Lia Ferreira do PAC da CDHU, a Daniela Lima do Escritório Técnico do Alegra Centro, a Eduardo Vianna Junior e Deborah Okida da ACMD, a Thaís Polydoro do Instituto Elos, a Dra. Tathianni Cristini Silva e a Cadu de Castro do SESC, pelas informações e materiais compartilhados.

O presente trabalho foi realizado com apoio da Coordenação de Aperfeiçoamento de Pessoal de Nível Superior (CAPES). 
Quando estou na cidade tenho a impressão que estou na sala de visita com seus lustres de cristais, seus tapetes de veludos, almofadas de cetim. E quando estou na favela tenho a impressão de que sou um objeto fora de uso, digno de estar num quarto de despejo.

Carolina Maria de Jesus 


\section{RESUMO}

Os cortiços são habitações bastante precárias utilizadas pelos trabalhadores de baixos redimentos em Santos-SP desde o século XIX. Apesar dos empreendimentos de habitação social a partir dos anos 1930 dos Institutos de Aposentadorias e Pensões até o Minha Casa Minha Vida na atualidade, o deficit habitacional do município é de 12 mil unidades habitacionais. As contradições, em uma cidade em que mais de um décimo das residências são de uso ocasional, se ampliam quando o bairro Paquetá, com grande concentração de cortiços, passa a ser reconhecido como patrimônio histórico pelo Programa Alegra Centro. Com a ameaça de gentrificação em seu bairro e apesar de inúmeros obstáculos, moradores de cortiços, organizados pela Associação dos Moradores de Cortiços do Centro constróem, por meio de autogestão, com recursos do Programa Crédito Solidário e do Minha Casa Minha Vida - Entidades, os Condomínios Vanguarda I e II (totalizando 113 apartamentos), localizados no Paquetá, resistindo à segregação socioespacial que tende a expulsar os trabalhadores mais pobres para as periferias.

Palavras-chave:cortiço; habitação de interesse social; patrimônio histórico; gentrificação; resistência. 


\begin{abstract}
The tenements are rather precarious housing used by low-income workers in Santos-SP since the 19th century. In spite of the social housing developments from the 1930s of the Institutos de Aposentadorias e Pensões to the Minha Casa Minha Vida nowadays, the housing deficit of the municipality is 12 thousand housing units. The contradictions, in a city in which more than a tenth of the residences are of occasional use, are amplified when the neighborhood Paquetá, with a great concentration of tenements, is now recognized as historical patrimony by the Alegra Centro Program. With the threat of gentrification in his neighborhood, and despite innumerable obstacles, tenants living in tenements organized by the Associação dos Moradores de Cortços do Centro built, through self-management, with resources from the Programa Crédito Solidário and Minha Casa Minha Vida - Entidades, condominiums Vanguarda I and II (totaling 113 apartments), located in Paquetá, resisting the socio-spatial segregation that tends to expel the poorer workers to the peripheries.
\end{abstract}

Key words: tenements; social housing; historical patrimony; gentrification; resistance. 


\section{LISTA DE FIGURAS}

Figura 1: Divisão dos bairros insulares no município de Santos ....................................18

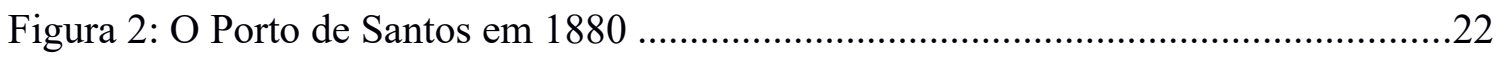

Figura 3: Trabalhadores do Porto de Santos transportam café para um navio. ..............23

Figura 4: Projeto de urbanismo de Saturnino de Brito. ..................................................28

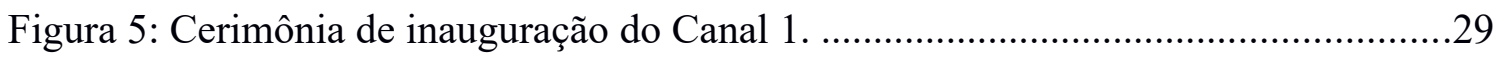

Figura 6: Cortiços existentes em Santos em 1889......................................................29

Figura 7: Primeiro palacete na Praia José Menino, antes de sua demolição em 1963. .. 34

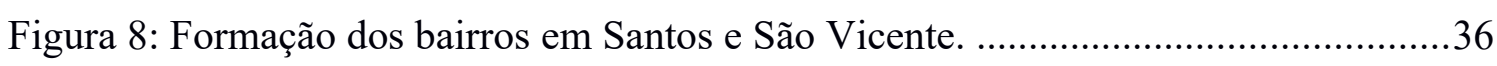

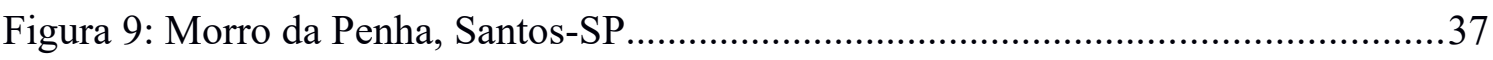

Figura 10: Evolução de domicílios encortiçados nos bairros centrais de Santos-S...........38

Figura 11: Zonas de Especial Interesse Social - Santos-SP........................................45

Figura 12: Áreas de Proteção Cultural do Programa Alegra Centro. ...............................48

Figura 13: Bens tombados no município de Santos-SP ...................................................49

Figura 14: Detalhe das muretas pintadas, em concurso artístico da Sec. de Cultura.......58

Figura 15: Muretas na Ponta da Praia - Santos-SP........................................................58

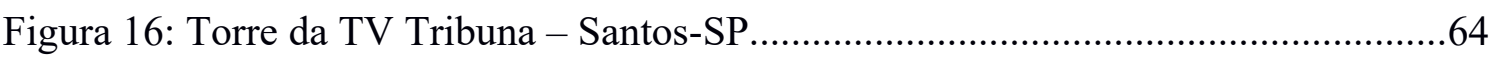

Figura 17: Imóveis da Rua Amador Bueno - Santos-SP ...........................................65

Figura 18: Fotografia aérea do Conjunto Residencial Enguaguaçu, Santos-SP, 1970 ...71

Figura 19: Vista geral do Conjunto Residencial Enguaguaçu, Santos-SP......................72

Figura 20: Planta da casa da Vila dos Portuários, Santos-SP........................................ 72

Figura 21: Vista de remanescente da Vila dos Portuários, Santos-SP.............................73

Figura 22: Casa do Conjunto Residencial do IAPB, Santos-SP......................................73

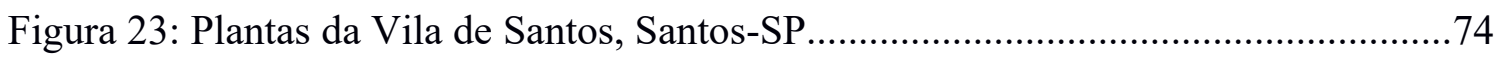

Figura 24: Plantas dos Núcleos Residenciais de Santos, Santos-SP..............................74

Figura 25: Planta do Núcleo Residencial Bacia do Macuco, Santos-SP...........................75

Figura 26: Planta da casa do Núcleo Residencial Bacia do Macuco, Santos-SP.............76

Figura 27: Vista de rua interna do Núcleo Residencial Bacia do Macuco, Santos-SP.....76

Figura 28: Fotografia aérea dos conjuntos do IAPI e do BNH, Santos-SP, 1970 ..........78

Figura 29: Conjunto do IAPI na sua inauguração, Santos-SP........................................79

Figura 30: Vista dos conjuntos do IAPI e do BNH, Santos-SP, década de 1990. ...........79 


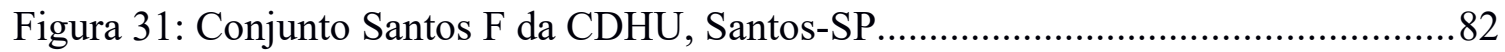

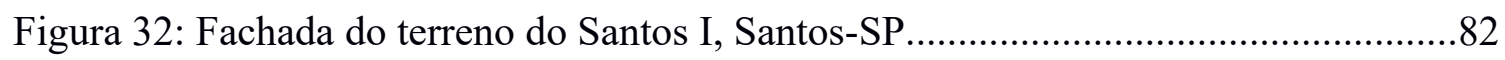

Figura 33: República de Idosos, bairro Encruzilhada, Santos-SP................................... 88

Figura 34: A Capela da Graça, tela de Benedito Calixto................................................... 96

Figura 35: Igreja da Matriz de Santos, tela de Benedito Calixto. .....................................97

Figura 36: Tapumes no envoltório da Casa de Câmara e Cadeia, Santos-SP - 2015. .. 105

Figura 37: Praça Nagasaki, Santos-SP....................................... 118

Figura 38: Padaria "Um Só Coração" e sede da ACC em sua inauguração............. 120

Figura 39: Turistas, membros da ACC e do Movimento Hip-hop do Mercado..............122

Figura 40: Exterior e interior de cortiços, Santos-SP .................................................. 123

Figura 41: Quintal e quartos ao fundo de um cortiço, em Paquetá, Santos-SP..............124

Figura 42: Interior de um quarto nos fundos de um cortiço em Paquetá, Santos-SP.....125

Figura 43: Projeto dos condomínios Vanguarda I e II em Santos-SP...........................131

Figura 44: Obras do condomínio Vanguarda I em Santos-SP......................................131

\section{LISTA DE TABELAS, QUADROS, GRÁFICOS E ORGANOGRAMAS}

Tabela 1: Promoção de unidades habitacionais por entidades públicas no Brasil .........71

Tabela 2: Unidades Habitacionais produzidas pela CDHU na Baixada Santista ............83

Tabela 3: Empreendimentos para a faixa de renda 1 do MCMV na Baixada Santista ...87

Tabela 4: Bens tombados pelo Condephaat em Santos-SP ...........................................103

Quadro 1: Dados do Censo dos Moradores de Cortiços - 2003 .....................................43

Gráfico 1: Imóveis desocupados e em ruínas e terrenos vazios nas APCs ......................59

Gráfico 2: Evolução da população no município de Santos-SP, de 1790 a 2010 ...........69

Organograma 1: Processo de Reabilitação de Cortiços ......................................................62 


\section{LISTA DE ABREVIATURAS}

ACC - Associação dos Moradores dos Cortiços do Centro (Santos)

ACMD - Associação Comunidade de Mãos Dadas (Santos)

APC - Área de Proteção Cultural

AGEM - Agência Metropolitana da Baixada Santista

AHVS - Associação Habitacional Vila Sapo (Santos)

BID - Banco Interamericano de Desenvolvimento

BNH - Banco Nacional de Habitação

CDHU - Companhia de Desenvolvimento Habitacional e Urbano do Estado de São Paulo

CHS - Centro Histórico de Salvador

CMP - Central de Movimentos Populares

CONDEPASA - Conselho de Defesa do Patrimônio Cultural de Santos

CONDEPHAAT - Conselho de Defesa do Patrimônio Histórico, Arqueológico, Artístico e

Turístico do Estado de São Paulo

CONPRESP - Conselho Municipal de Preservação do Patrimônio Histórico, Cultural e Ambiental da Cidade de São Paulo

COHAB-ST - Companhia de Habitação da Baixada Santista

CPC - Corredores de Proteção Cultural

DHP - Departamento de Habitação Popular

FCP - Fundação Casa Popular

FDS - Fundo de Desenvolvimento Social

FGTS - Fundo de Garantia do Tempo de Serviço

FONSAL - Fundo de Salvamento do Patrimônio Cultural (Quito, Equador)

GIDUR - Gerência de Desenvolvimento Urbano (da Caixa Econômica Federal)

HIS - Habitação de Interesse Social

IAPs - Institutos de Aposentadorias e Pensões

IAPB - Instituto de Aposentadoria e Pensões dos Bancários

IAPC - Instituto de Aposentadoria e Pensões dos Comerciários

IAPFESP - Instituto de Aposentadoria e Pensões dos Ferroviários e Empregados em Serviços Públicos

IAPI - Instituto de Aposentadoria e Pensões dos Industriários 
IAPM - Instituto de Aposentadoria e Pensões dos Marítimos

IAPETC - Instituto de Aposentadoria e Pensões dos Empregados em Transportes e Cargas

IHG - Instituto Histórico e Geográfico

IPAC - Instituto do Patrimônio Artístico e Cultural da Bahia

IPASE - Instituto de Previdência e Assistência dos Servidores do Estado

IBGE - Instituto Brasileiro de Geografia e Estatística

IPHAN - Instituto do Patrimônio Histórico e Artístico Nacional

IPTU - Imposto Predial e Territorial Urbano

IPVS - Índice Paulista de Vulnerabilidade Social

ISSQN - Imposto sobre Serviços de Qualquer Natureza

ITBI - Imposto de Transmissão de Bens Intervivos

NP - Nível de Proteção

MNLM - Movimento Nacional de Luta por Moradia

MPM - Movimento Popular por Moradia

MCMV - Minha Casa Minha Vida

MCMV-E - Minha Casa Minha Vida - Entidades

ONU - Organização das Nações Unidas

PAC - Programa de Atuação em Cortiços (CDHU)

PCB - Partido Comunista Brasileiro

PCS - Programa Crédito Solidário

PP - Partido Progressista

PPP - Parceria Público-Privada

PRNH - Programa de Recuperação e Revitalização de Núcleos Históricos

PROURB - Programa de Animação Urbana da Baixada Santista

PSDB - Partido da Social-Democracia Brasileira

PT - Partido dos Trabalhadores

SEADE - Fundação Sistema Estadual de Análise de Dados

SEDURB - Secretaria de Desenvolvimento Urbano (Prefeitura de Santos-SP)

SEPLAN - Secretaria de Planejamento (Prefeitura de Santos-SP)

SESC - Serviço Social do Comércio

SETAC - Seção Escritório Técnico Alegra Centro (Prefeitura de Santos-SP)

SPHAN - Serviço do Patrimônio Histórico e Artístico Nacional 
UH - Unidade Habitacional

UNESCO - Organização das Nações Unidas para a Educação, a Ciência e a Cultura UNMM - União Nacional de Movimentos de Moradia

UNMP - União Nacional por Moradia Popular

VLT - Veículo Leve sobre Trilhos

ZERUS - Zonas Especiais de Renovação Urbana

ZEIS - Zona Especial de Interesse Social 


\section{SUMÁRIO}

Introdução.

Capítulo 1: De cortiço a patrimônio arquitetônico.

1.1 Alegra Centro Habitação 60

Capítulo 2: Políticas públicas de habitação em Santos-SP 69

Capítulo 3: Direito à Memória e Políticas de Preservação do Patrimônio em Santos-SP 91

3.1 As políticas de preservação em Santos-SP .95

$3.2 \mathrm{O}$ patrimônio habitado. 107

Capítulo 4: Mudar sem se mudar: a resistência da Associação dos Moradores dos Cortiços do Centro de Santos-SP. 115

Considerações Finais 137

Referências Bibliográficas. 146

Anexo I: Cortiços nos bairros centrais de Santos-Prefeitura de Santos - 2010 161

Anexo II: Projeto da creche da ACC - Instituto Elos 162 


\section{Introdução}

O deficit habitacional urbano brasileiro (em 2014) é superior a 5 milhões de unidades habitacionais, segundo a Fundação João Pinheiro (2016). Na cidade portuária de Santos-SP, a questão habitacional é um grave problema social; de acordo com o Censo de 2010, 38.159 pessoas habitavam 10.767 moradias em aglomerados subnormais ${ }^{1}$ na cidade e o deficit habitacional era de 12.115 unidades, ainda que o município tivesse quase 17 mil unidades vagas. Dos 144 mil domicílios na cidade, $11,3 \%$ são de uso ocasional, utilizados como segunda residência.

Na década de 1980, principalmente durante o processo de redemocratização do país, os movimentos sociais por direitos se fortaleceram, dentre eles os movimentos por moradia. Organizações de nível nacional, como o Movimento Popular por Moradia (MPM), ou a União Nacional por Moradia Popular (UNMP), e de nível local pressionaram os governos, em todas as esferas, pela concretização do direito constitucional à moradia. Muitos desses movimentos se engajaram na autoconstrução de moradias e na autogestão.

Em Santos também surgiram reivindicações e movimentos populares, dentre eles a Associação dos Moradores dos Cortiços do Centro (ACC), criada na década de 1990 a partir das reivindicações da população encortiçada por habitação de qualidade e emprego. As lutas da associação começaram pela reforma de uma praça, mobilizando moradores, organizações não governamentais (ONGs) e poder público para tornar esse espaço público mais adequado às necessidades dos usuários, com a criação um parquinho para as crianças, a recuperação do paisagismo e a instalação de novos bancos.

A ACC montou, com auxílio da assessoria técnica da ONG Instituto Elos, dois projetos de geração de rendimentos para a comunidade: 1) a padaria "Um só coração", localizada no bairro Paquetá, ${ }^{2}$ com alvará de funcionamento desde setembro de 2010, e gerida por doze

1 O IBGE conceitua como aglomerado subnormal um conjunto com 51 ou mais unidades habitacionais caracterizadas por ausência de título de propriedade e pelo menos uma das seguintes características: irregularidade de vias de circulação ou do tamanho dos lotes; carência de rede de esgoto ou de água, energia elétrica, coleta de lixo ou iluminação pública (IBGE, 2010). Ou seja, o que coloquialmente é chamado de favela é padronizado conceitualmente pelo instituto e, embora esse conceito não inclua os cortiços, é importante para determinar o deficit habitacional. De acordo com Censo de 2010, 17,93\% da população (297.191 pessoas) da Região Metropolitana da Baixada Santista moravam em aglomerados subnormais. A proporção cai para 9,13\% (38.159 pessoas) quando se considera somente o município de Santos (IBGE, 2011).

2 Bairro da porção insular do município de Santos-SP, vizinho ao centro. Na figura 1 apresentamos os bairros santistas da Ilha de São Vicente, pois os bairros continentais abrigam a minoria da população do município. 
mulheres moradoras de cortiços com base em princípios da economia solidária; e 2) o ateliê "Raízes Corticeiras", que confecciona bijuterias feitas com tecido de chita. Graças à assessoria técnica, o ateliê conseguiu comercializar seus produtos no exterior, mantendo inclusive um ponto de venda em Boston. Isso melhorou não somente a situação financeira das trabalhadoras envolvidas - fato importantíssimo, considerando que mais da metade da população encortiçada vive com até um salário-mínimo per capita -, mas também sua autoestima, com a formação de relações de trabalho solidárias. Esses dois projetos têm importante protagonismo feminino, essencial para uma população com grande quantidade de mulheres jovens chefes de família e com baixa escolaridade.

Em 2007, a ACC tornou-se a primeira entidade a conseguir a doação de um imóvel da União com a finalidade de produção de habitação de interesse social (HIS), ao receber um terreno (um antigo armazém de café) no bairro Paquetá. Em seguida foi criada a Lei n ${ }^{\circ} 11.481$, de 31 de maio de 2007, que regulamenta a doação de imóveis da União para HIS. No ano seguinte, a associação obteve um financiamento de $\mathrm{R} \$$ 4,515 milhões ${ }^{3}$ do Programa Crédito Solidário para a construção do conjunto habitacional "Vanguarda I", com 113 unidades.

O projeto deste condomínio define quatro tipologias para os apartamentos: sala living, um dormitório, dois dormitórios e três dormitórios. O financiamento de cada apartamento será pago em parcelas mensais R $\$ 125,00$ ao longo de 20 anos. A construção do condomínio é realizada com apoio de mutirão dos futuros moradores, que com isso conseguem abater grande parte do valor do imóvel por meio de trabalhos como auxiliar de pedreiro e outras funções, respeitando as capacidades de cada um. As horas de mutirão são proporcionais ao tamanho do apartamento (e, consequentemente, ao número médio de moradores por apartamento), sendo que os futuros moradores de apartamentos sala living, de um quarto, de dois quartos e de três quartos devem trabalhar, respectivamente, 8, 11, 13,5 e 16 horas semanais como contribuição. A execução do projeto é autogestionária, e todas as decisões são tomadas em assembleias realizadas quinzenalmente.

Já o "Vanguarda II", com previsão de 68 unidades habitacionais, foi o primeiro empreendimento financiado pelo programa do governo federal Minha Casa Minha Vida Entidades, em janeiro de 2010. O valor total é de R $\$ 4,143$ milhões, ${ }^{4}$ sendo que os moradores terão que pagar $10 \%$ de seu salário, ao longo de 10 anos. O projeto arquitetônico conta com:

3 US\$ 2.134.449,09. Valor convertido segundo taxa de câmbio de 01 nov. 2008. (R\$ 7.342.750,46 em março de 2018). Todas as correções e conversões de valores foram feitas a partir de dados do Banco Central do Brasil. 4 US\$ 2.379.393,67. Valor convertido segundo taxa de câmbio de 01 jan. 2010. (R\$ 6.837.932,43 em março de 2018). 
3 edifícios de 4 pavimentos, e terão 3 tipologias distintas: 1, 2 e 3 dormitórios. Nesta segunda etapa, não foram previstas unidades do tipo sala living. As áreas comuns contarão com mais 2 salas institucionais, Centro Comunitário, áreas de lazer para crianças e idosos, e estacionamentos para carros e motos. Todos os apartamentos do pavimento térreo foram projetados para serem acessíveis aos portadores de necessidades especiais e com dificuldades de locomoção (UNMP, 2010).

O grande diferencial do projeto é o fato de o terreno estar próximo ao centro da cidade, pois a maioria dos empreendimentos nas grandes cidades, tanto do Programa Crédito Solidário (PCS) quanto do Minha Casa Minha Vida - Entidades (MCMV-E), está localizada nas periferias ou até mesmo em outras cidades da região metropolitana. A doação de imóveis abandonados ou subutilizados da União para projetos de habitação social é o que possibilita que alguns poucos movimentos conquistem a moradia sem sair do centro da cidade, indo na contramão da tendência de segregação socioespacial da maioria dos empreendimentos de habitação social, desde a criação do Banco Nacional de Habitação (BNH), porque a construção (ou o financiamento) desses projetos não está aliada a uma política fundiária que possibilite que uma habitação de interesse social (HIS) seja construída em áreas centrais das cidades.

A maior parte dos cortiços dos bairros centrais de Santos está em imóveis do final do século XIX e começo do século XX que tiveram seu valor histórico reconhecido em um programa da Prefeitura Municipal de Santos $^{5}$ chamado Alegra Centro, iniciado em 2003, que concedia incentivos fiscais aos proprietários de imóveis históricos que restaurassem as suas fachadas. Sem levar em consideração que muitos desses imóveis abrigavam famílias em situações de moradia muito precárias. O programa, que será detalhado no capítulo 1, impulsiona uma tendência a maiores investimentos nos bairros centrais e seu entorno e pode, com o passar do tempo, consolidar um processo de gentrificação desses bairros.

Durante o decorrer da investigação, nos deparamos com uma pergunta fundamental para o caso dos bairros centrais santistas: como conciliar a preservação do patrimônio cultural e políticas públicas para habitação social? Existem experiências bem-sucedidas em vários centros históricos no mundo, mas poucas no Brasil, em que os imóveis históricos podem manter (ou iniciar) sua função de moradia, como em Bolonha, Porto, Quito e Olinda, em que se aliou a restauração do patrimônio com o uso habitacional.

5 Gestões da Prefeitura Municipal de Santos desde a redemocratização: Oswaldo Justo (PMDB), 1984-1988; Telma de Souza (PT), 1989-1992; David Capistriano Filho (PT), 1993-1996; Beto Mansur (PPB e PP), 1997-2004; João Paulo Tavares Papa (PSDB), 2005-2012; Paulo Alexandre Barbosa (PSDB) 2012- 
Figura 1: Divisão dos bairros insulares no município de Santos.

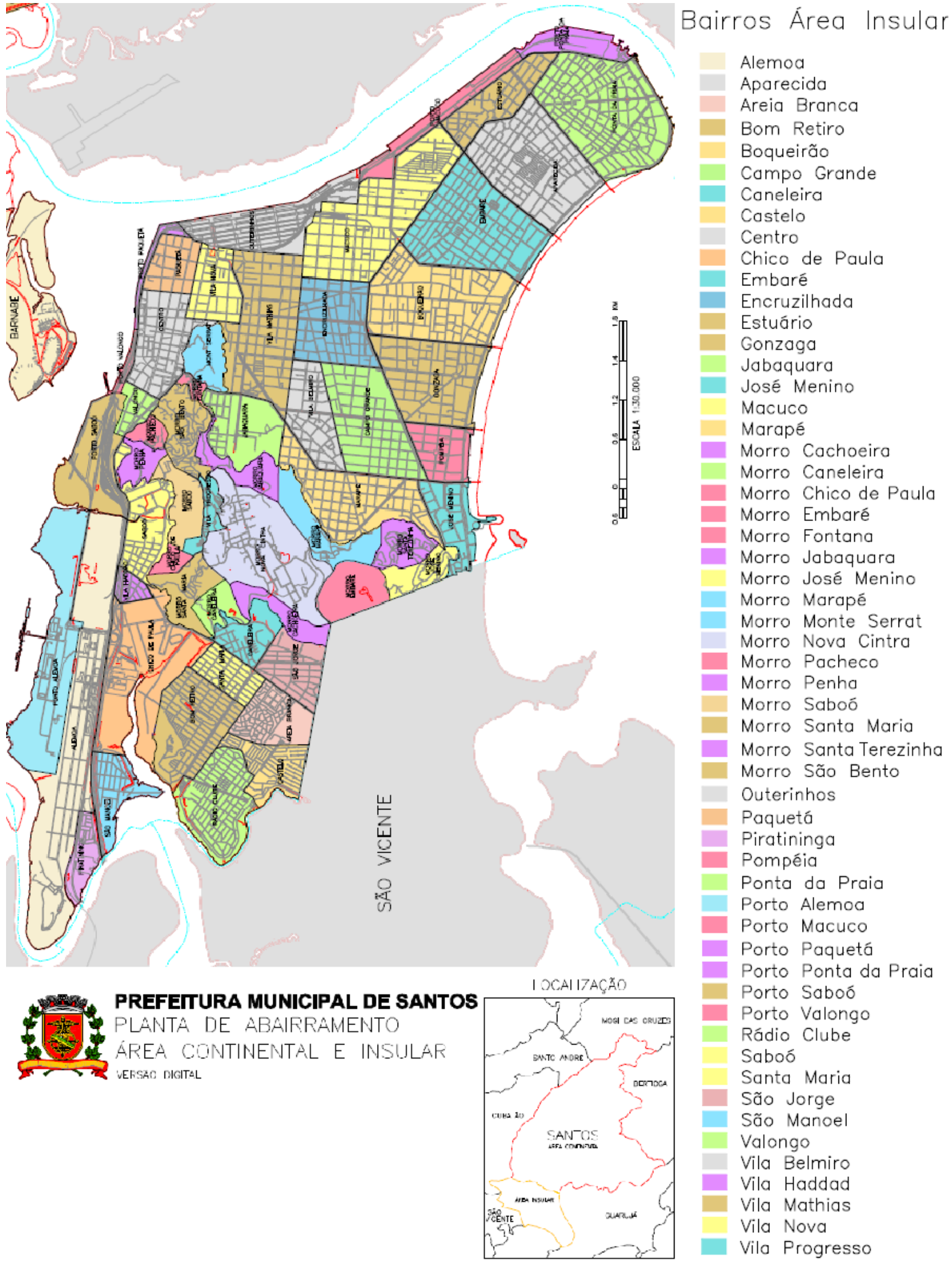

Fonte: Prefeitura Municipal de Santos-SP (adaptado). 
Para entender a realidade da questão habitacional na qual a ACC está inserida, no capítulo 2 abordaremos as políticas de habitação social em Santos, como os conjuntos habitacionais dos Institutos de Aposentadorias e Pensões (IAPs), da Fundação Casa Popular (FCP), do Banco Nacional de Habitação (BNH) e da Companhia de Desenvolvimento Habitacional e Urbano (CDHU) e, mais recentemente, o Programa Crédito Solidário e o Minha Casa Minha Vida, principalmente a sua modalidade Entidades, que concedeu financiamentos a movimentos sociais e associações para construção de moradias.

No terceiro capítulo são apresentadas as políticas públicas de preservação do patrimônio em Santos desde a década de 1930, o envolvimento de parcela da população nos pedidos de tombamento a partir da década de 1970 e o questionamento dos usos e funções do patrimônio tombado na atualidade. São apresentadas também experiências bem sucedidas que aliaram preservação do patrimônio e habitação.

Por fim, no quarto capítulo ${ }^{6}$, veremos as relações da ACC com o poder público a nível federal, estadual e municipal, com a Caixa Econômica e as assessorias técnicas (as ONGs Instituto Elos, Associação Comunidade de Mãos Dadas e Peabiru), bem como suas relações internas de organização, na luta para conquistar melhores condições de vida, sobretudo no que tange à habitação. Foi utilizada a metodologia de trabalho de Gohn (2007) para análise de movimentos sociais, levando em consideração a composição do movimento, a origem social dos integrantes e seu princípio articulatório, as demandas e repertórios da ação coletiva, as bases, lideranças e assessorias participantes do movimento. Também propõe a averiguação de alianças externas, relações com outros movimentos sociais, ideologia do movimento, formas de organização e suas práticas (desde discursos até ações diretas), a formação de sua identidade, o cenário sociopolítico no qual está inserido bem como as questões de ordem mais prática, os opositores, os aliados, as conquistas e as derrotas. Além disso, apresenta uma perspectiva de entender os movimentos sociais em duas escalas, a micro, cujos aspectos foram acima expostos, e a macro, o contexto maior de ação do movimento.

Para a realização desta pesquisa, além da revisão de literatura, foram realizadas entrevistas com representantes das ONGs acima mencionadas, com servidores públicos do escritório técnico do Alegra Centro e da CDHU, com membros da ACC e com outros moradores de cortiços, além de análise de leis referentes ao direito à moradia e suas políticas públicas e ao planejamento urbano de Santos, planos de habitação municipal, e diversos materiais

6 Por uma questão de redação o Condomínio Vanguarda e a ACC serão analisados no último capítulo, pois se considerou necessária a contextualização da realidade em que estes estão inseridos. 
produzidos pela Prefeitura e pela CDHU.

Embora o primeiro contato com a ACC tenha sido em 2010, em um trabalho de campo da disciplina de "Geografia Urbana" no curso de Geografia da Universidade Estadual Paulista "Júlio de Mesquita Filho" campus Rio Claro, o contato foi retomado durante a elaboração do projeto de pesquisa do mestrado, com visitas pontuais e posteriormente com o apoio na organização da biblioteca comunitária da associação e a participação nas suas atividades de turismo social, nestes momentos foram coletados informações e depoimentos com os membros da ACC e moradores do Paquetá.

Durante esta investigação pretendemos responder como um movimento de luta por moradia pode construir um projeto de resistência às tendências de segregação socioespacial, diminuição dos espaços públicos e subjugação da moradia ao seu valor de troca. Entender de que formas a autogestão habitacional, por meio do exemplo da ACC, com suas possibilidades e desafios, pode criar espaços distintos na cidade, que fogem da lógica hegemônica da moradia como uma mercadoria qualquer.

Entendemos que o esforço em pesquisar movimentos sociais que trabalham no sentido da ampliação de direitos e da construção de uma cidade diferente e mais justa é importante principalmente para socializar essas histórias e talvez contribuir para que outros movimentos trilhem caminhos similares de resistência. "Transformar o mundo é interpretá-lo para transformá-lo. É também transformá-lo ao interpretá-lo" (BENSAID, 2001, p. 225, tradução nossa). ${ }^{7}$

7 “Changer le monde, c'est l'interpréter pour le changer. C'est aussi le changer en l'interprétant.” (BENSAID, 2001. p. 225). 


\section{Capítulo 1: De cortiço a patrimônio arquitetônico}

Oh senhor cidadão, eu quero saber, eu quero saber com quantos quilos de medo, com quantos quilos de medo se faz uma tradição? Tom Zé

Na Ilha de São Vicente, no século XVI, se instalou um povoado que teria grande importância no Brasil Colonial para a metrópole portuguesa, com a centralidade no tráfico de escravos: o Porto dos Escravos. ${ }^{8} \mathrm{Na}$ década de 30 daquele século instalaram-se três engenhos de açúcar, ${ }^{9}$ dois deles na própria Ilha de São Vicente e um no que viria a ser a área continental do município de Santos. Também nessa década, a chegada de Martim Afonso, enviado de Portugal para administrar a Capitania Real de São Paulo, reforçou a importância do povoado, pois este oficializou uma estrutura político-administrativa - câmara de vereadores, igreja, pelourinho, cadeia - e, além disso, distribuiu as terras em sesmarias.

As funções portuária e comercial foram as principais da Vila de Santos por séculos, ainda que durante o século XVIII a Vila tenha sofrido uma certa decadência econômica, causada pelo Ciclo do Ouro, com a consequente internalização da economia colonial, e pela concorrência do açúcar pernambucano. Assim, no final daquele século, o governador tomou duas providências: decretou o fechamento dos outros portos da Capitania, tornando o Porto de Santos o único, e a construção da Calçada do Lorena, caminho que passou a ligar o Planalto Paulista a Santos pela Serra do Mar, facilitando as viagens e o escoamento de mercadorias. Moraes (1999, p. 33-4) relata que durante o período colonial a polarização de Santos e São Vicente com sua conexão com o Planalto Paulista

Destaca-se exatamente mais pela extensão dessa área de circulação (cujos fluxos chegam a atingir o Peru) que pela magnitude de seus assentamentos em si, no período colonial. Constitui-se de um rosário de núcleos litorâneos que se tornam mais distanciados conforme se avança no sentido meridional (o limite sul deste sistema estaria, na época considerada, na ilha de Santa Catarina).

8 O povoado fazia parte da área controlada pelo Bacharel de Cananeia, que comercializava produtos diversos, além de ser o maior traficante de escravos daquela região (seu controle territorial chegava até o atual Estado de Santa Catarina), quase 30 anos antes de Martim Afonso desembarcar na ilha e batizá-la de São Vicente, em 1532 .

9 Engenho da Madre de Deus, Engenho São João (posteriormente conhecido como Engenho São Jorge dos Erasmos, cujas ruínas estão abertas a visitação até hoje) e Engenho do Trato. 
Apesar dessas medidas tomadas pelo governador, Santos só voltou a ter uma expansão significativa no século XIX, quando o café se tornou o principal produto de exportação do Estado de São Paulo. Em 1854, o Porto de Santos foi responsável por 80\% da exportação deste produto. Em 1857, iniciou-se a construção da primeira ponte flutuante da Alfândega, na tentativa de criar um porto organizado para substituir o simples ancoradouro existente. Dois anos depois essa ponte foi inaugurada, e em 1870 já existiam nove pontes e trapiches construídos pela iniciativa privada (LOPES, 1975). As atividades urbanas da economia cafeeira se dividiam entre São Paulo e Santos, que aumentaram sua conexão com o abandono do Caminho do Mar $^{10}$ e sua substituição pela linha de ferro São Paulo Railway, instalada em 1867 com capital inglês, que ligava São Paulo à estação de trem situada no Valongo, área próxima ao Porto de Santos.

Figura 2: O Porto de Santos em 1880.

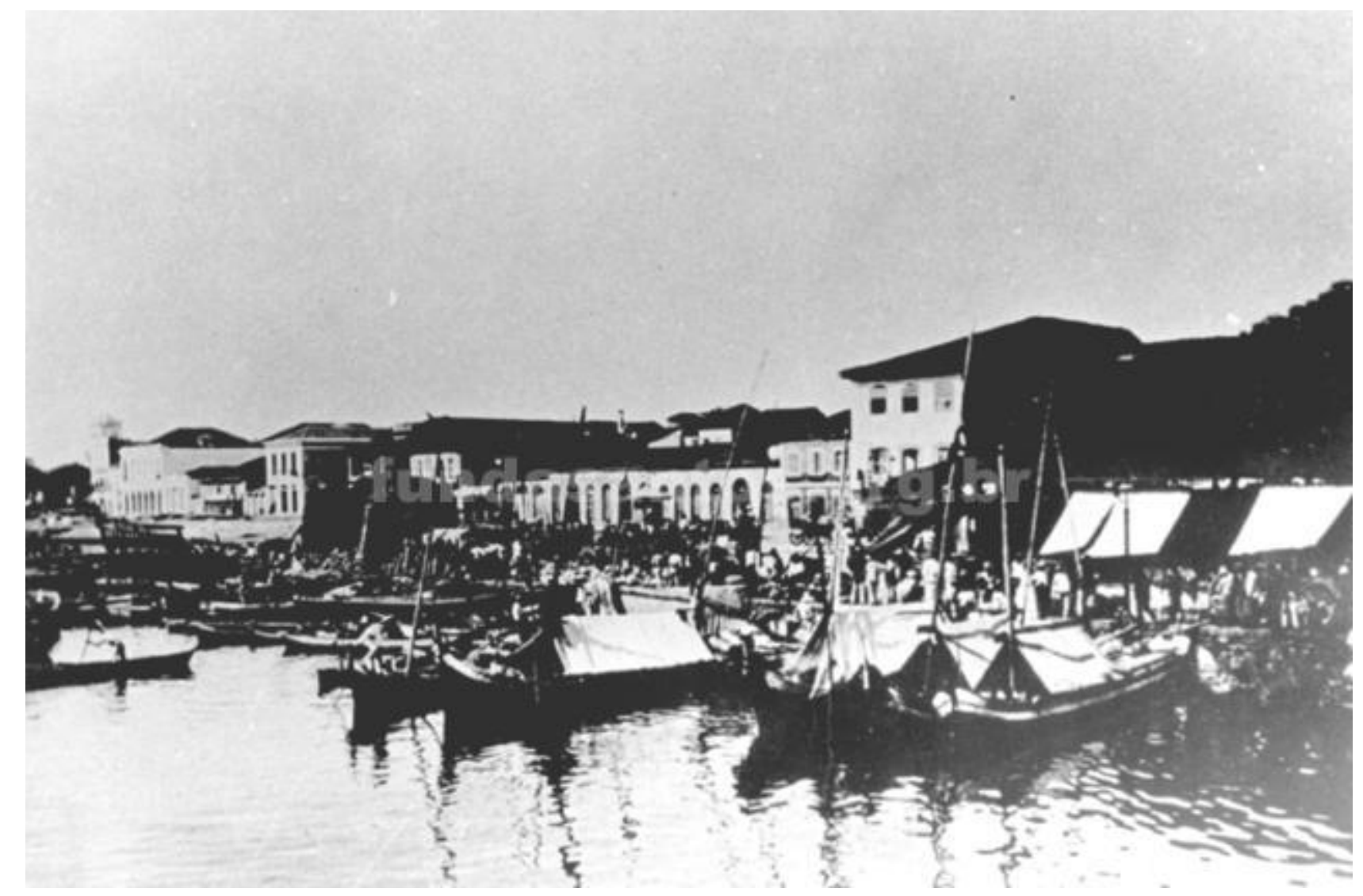

Fonte: Fotografia de Marc Ferrez, Fundação Arquivo e Memória de Santos-SP.

"Ferrovia e porto redefiniram a região do Valongo, tornando-a uma área de habitação de

10 O Caminho do Mar, ou Estrada Velha de Santos, foi construído pelos jesuítas em meados do século XVI. Era a principal rota entre Santos e o interior . No fim do século XVIII, a parte da serra foi pavimentada e rebatizada de Calçada do Lorena. 
trabalhadores vinculados aos serviços portuários (doqueiros, estivadores, carroceiros, ferroviários e ensacadores de café)" (BARBOSA, 2000, p. 36). Essas mudanças foram acompanhadas por significativo crescimento populacional: entre 1822 e 1854 a cidade passou de 4.781 habitantes para 7.855. Nesse período algumas poucas famílias já optavam por morar próximas à orla marítima e afastadas do centro, da ferrovia e do porto. Formou-se também o bairro Vila Nova, no qual muitas famílias mais abastadas se estabeleceram, saindo do centro e do Valongo.

O Porto de Santos passou por transformações no final do século XIX. O aumento do fluxo de mercadorias mostrou a necessidade de instalações maiores, o que levou a Companhia Docas de Santos a iniciar uma expansão. O primeiro trecho do cais ampliado, com mais de dois quilômetros, e o primeiro armazém foram inaugurados em 1892; essa reforma também conectou o cais do porto com a ferrovia.

O contrato inicial da construção do porto previa: uma faixa de 20 metros de largura para depósito de mercadorias; galpões para armazenamento; e substituição dos guindastes a vapor por hidráulicos. Como houve constante necessidade de ampliação do cais, novos contratos foram sendo firmados e alterados com a Cia. Docas (LOPES, 1975).

Figura 3: Trabalhadores do Porto de Santos transportam café para um navio.

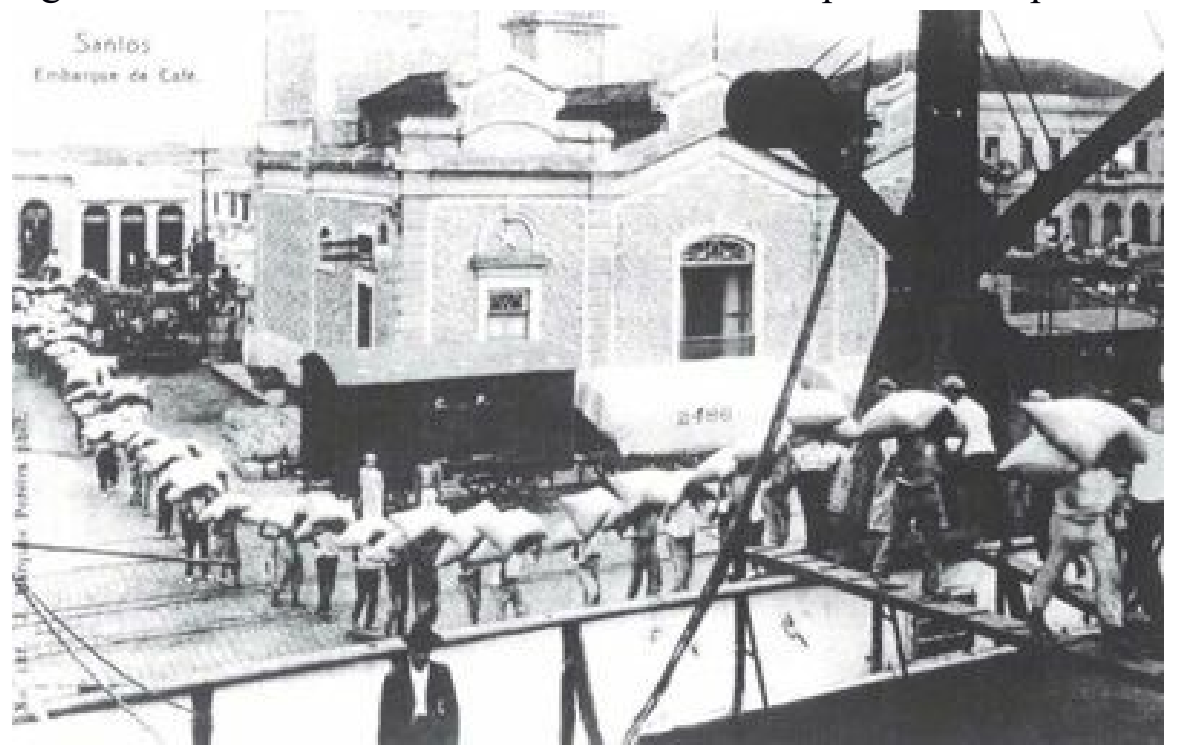

Fonte: Acervo da Fundação Arquivo e Memória de Santos apud Barbosa, 2000.

O crescimento do movimento portuário provocou novo e expressivo aumento populacional na cidade, que passou de 15.505 habitantes em 1886 para 50.389 em 1900. No entanto, não havia moradias adequadas para comportar tal aumento populacional e, assim, grande parcela da 
população vivia em condições insalubres.

Já no final do século XIX, os habitantes dos segmentos sociais de baixos rendimentos muitos dos quais imigrantes - viviam em cortiços no centro da cidade, pela facilidade de acesso ao trabalho, ao comércio e aos diversos serviços da cidade. Essa população era desde essa época vítima de leis sanitárias autoritárias, que permitiam a fiscalização forçada dos cortiços, considerados focos de epidemias. Frequentemente, as ações com base nessas leis se traduziam em repressão violenta aos moradores (BERNARDINI, 2006).

Essa situação não era exclusiva de Santos: outras grandes cidades brasileiras também tinham graves problemas de habitação e muitos cortiços, como durante a República Velha (entre 1894 e 1930), quando o Estado deixava a questão da construção de moradias para a iniciativa privada e mantinha somente ações de repressão em situações graves de insalubridade e epidemias, por meio de leis e ação policial (BONDUKI, 1994).

Os primeiros casos de febre amarela em Santos ocorreram em 1850, com a chegada de um navio de New Orleans cuja tripulação sofria da moléstia. O problema cresceu até que em 1889 a cidade passou por surtos concomitantes de febre amarela, malária, peste bubônica, varíola e tuberculose. Entre 1895 e 1902, mais de um quarto dos 7.497 óbitos ${ }^{11}$ em Santos foram decorrentes da febre amarela. A própria imigração diminuiu durante o período das graves epidemias, numa fase em que grande parte dos imigrantes entrava no país pelo Porto de Santos para trabalhar na cafeicultura: a Itália chegou mesmo a restringir as imigrações por este porto e, posteriormente, para o Brasil (LOPES, 1975).

Como consequência das epidemias, algumas ações foram tomadas: construção do Lazareto em 1881 (e sua ampliação em 1892), para a desinfecção de passageiros e de cargas; reforma da Santa Casa de Misericórdia; criação da Junta de Higiene Municipal em 1890 e da Vigilância Sanitária Estadual nove anos depois; e a criação de laboratórios bacteriológicos de análise química e farmacêutica em 1895.

Alguns relatos do período nos auxiliam a compreender que não somente as características climáticas (calor e umidade praticamente constantes ao longo do ano) propiciaram a propagação dessa e de outras doenças, mas também as características das edificações e da

11 Os dados encontrados sobre a mortalidade da febre amarela são conflitantes. Gitahy (1992) informa que no mesmo período foram 2.186 óbitos pela doença, de um total de 12.738 . No entanto, no período entre $1891 \mathrm{e}$ 1902 ele relata uma proporção de óbitos por essa doença similar à levantada por Lopes, 27\% dos 24 mil óbitos. Outras epidemias no período: tuberculose (7,6\% dos óbitos) e malária (5,1\% dos óbitos). Considerando a população da cidade nos anos mais graves das epidemias, a febre amarela sozinha era responsável pela morte de $5 \%$ dos habitantes. Como Lopes pesquisou especificamente a relação entre a febre amarela e o Porto de Santos, provavelmente seus dados são mais precisos. 
higiene:

As condições hygiênicas desta cidade são as piores possíveis e muito, senão tudo há a fazer para torná-la apta a repelir inimigos traiçoeiros que aparecendo entre nós aniquila milhares de vidas preciosas trazendo ao mesmo tempo o terror e com elle avultado prejuiso ao Commercio. (...) $\mathrm{O}$ grande número de cortiços no mais deplorável estado, tornando quasi todos completamente inhabitáveis, foi o principal factor da medonha epidemia que desenvolveo-se ultimamente (...) cubículos feitos de tábuas, baixos cobertos de zinco; composto de um só commodo, acanhadíssimos, onde habitam famílias numerosas, servindo elle só de cozinha, dormitório, sala de jantar e ao mesmo tempo de lactrina e terá uma idea muito palida do que o Cortiço n'esta Cidade.

Não estando elles em condições de ser melhorados, mas somente de serem demolidos não é possível obrigar seus proprietários a fazerem-no pois tais habitações numerosas e o seu abandono importa a atirar na rua um número considerável de indivíduos que não encontrarão moradia por falta absoluta de casas para recebê-los.

Assim pois, torna-se indispensável a edificação de cazinhas onde o trabalhador encontre por um preço modico moradia que trazendo-lhe certo bem estar seja ao mesmo tempo uma garantia de saude de toda população. (Barão de Jaguara, ofício de 17 de maio de 1889 da Comissão de Vigilância Sanitária de Santos ao presidente da Província. Arquivo do Estado de São Paulo - Documentos do Barão de Jaguara, caixa 5553, manuscrito. Apud LOPES, 1975, p. 158) ${ }^{12}$.

Este ofício também relatava a existência de áreas alagadiças na cidade, das quais a mais preocupante era o cemitério do Paquetá, que no período mais chuvoso podia ser encontrado alagado, com enxurradas tão fortes que podiam desenterrar vários corpos.

A falta de esgoto e de pavimentação e as consequentes áreas alagadiças formam ambientes favoráveis para a reprodução dos mosquitos que transmitem o vírus causador da febre amarela, segundo as descobertas dos médicos Emílio Ribas e Adolfo Lutz, que em 1903 confirmaram a teoria ${ }^{13}$ de que a enfermidade era transmitida por mosquitos, em especial pelo Aedes aegypti. ${ }^{14}$ A partir dessas descobertas começaram as ações das comissões sanitárias para impedir a procriação dos mosquitos nas cidades afetadas pela epidemia. Como os pacientes contagiados pela febre amarela podem ser picados por outro mosquito e este pode

12 Os trechos de documentos antigos estão reproduzidos conforme a ortografia da época.

13 Existiam, no final do século XIX, duas teorias conflitantes sobre o contágio da febre amarela. Alguns cientistas acreditavam que ela era transmitida por microrganismos presentes em bolores ou através do ar contaminado pelos enfermos; já o médico cubano Carlos Finlay defendia a tese de que o microrganismo causador da doença era transmitido por mosquitos. Adolfo Lutz e Emílio Ribas conduziram experimentos baseados na teoria de Finlay e a confirmaram. Emílio Ribas escreveu recomendações para combater a epidemia, como não manter água parada, adicionar querosene nas águas para matar as larvas e colocar telas em janelas e portas para impedir a entrada do mosquito nas casas (FRANCO, 1969).

14 O mosquito na época era conhecido pelos nomes Stegomyia fasciata e Culex taeniatus, rebatizado em 1926 como Aedes aegypti (MARCOLIN, 2009). É o principal transmissor da febre amarela em ambientes urbanos. 
infectar outras pessoas entre 12 e 14 dias após os primeiros pacientes contraírem a doença, a cidade tem que ser examinada pelas comissões sanitárias em busca de focos do mosquito em até seis dias. Em Santos dividiu-se a cidade em distritos e em seções para as inspeções sanitárias.

Além das epidemias, a população também sofria com o precário abastecimento de água. Em 1870, a The City of Santos Improvements Company Limited iniciou o abastecimento de água potável aos domicílios; ${ }^{15}$ no entanto, dez anos depois a empresa entrou em conflito com a população pelo não pagamento das contas. Em 1884, o corte no fornecimento de água provocou uma grande revolta. Em 1891, a escassez de água levou ao racionamento e muitas casas passaram a armazenar água em recipientes, o que contribuiu para a proliferação de mosquitos transmissores da febre amarela.

No final do século XIX, com a necessidade de expansão da área construída da cidade e com o problema dos alagamentos e das epidemias, começou-se a pensar em um planejamento urbanístico para a cidade. Os alagamentos ocorriam porque a maior parte da área urbana de Santos estava (e ainda está) localizada na porção oriental da Ilha de São Vicente. As áreas mais centrais da ilha têm morros (como o Monte Serrat e o Saboó) que chegam a 200 metros de altitude, enquanto o restante é constituído por cotas baixas, de cerca de 2 metros acima do nível do mar, com um lençol freático bastante superficial, de profundidade de cerca de 1,5 metro. Essas características, somadas a um clima úmido a superúmido (SANTOS, 1976) e às influências das marés provocava alagamentos em vários bairros, como Paquetá e Valongo, e nas áreas que viriam a formar os bairros da orla oceânica: Gonzaga, Boqueirão, José Menino e Ponta da Praia.

Em 1896, o governo do Estado de São Paulo autorizou obras de saneamento em São Paulo, Campinas e Santos, assim como em outras cidades em que havia epidemias de febre amarela. O engenheiro sanitarista Saturnino de Brito foi escolhido para encabeçar o planejamento urbanístico; ele tinha ideias e técnicas sanitaristas inovadoras, direcionadas para uma cidade com qualidade da água e do ar e boa circulação viária.

A grande intervenção urbanística acompanhava a tendência de reformas de outras cidades, como Rio de Janeiro e Belo Horizonte, em que se contemplavam tanto as questões sanitárias quanto a estética moderna - muito inspirada na Paris de Haussman -, com novas construções,

15 Anteriormente as pessoas buscavam água em córregos ou em poços (muitos contaminados pela ausência de canalização de esgoto) e, a partir de 1846, em chafarizes. Neste ano o primeiro chafariz foi inaugurado por D. Pedro II e na virada do século havia mais de 20 na cidade. 
jardins e grandes avenidas que possibilitassem a utilização do automóvel. Saturnino de Brito planejou os canais para escoamento das águas pluviais - que até hoje servem como marco para deslocamento e localização na cidade -, destinados a impedir os alagamentos; grande expansão na rede de água e esgoto; jardins nos subúrbios - para quebrar correntes de vento, possibilitar infiltração da água e contribuir para o conforto urbano, embora não tenham sido todos concluídos $^{16}$-; o grande jardim na orla da praia, com mais de 5 quilômetros de extensão, e o combate às epidemias. A cidade ganhou quase 200 hectares de áreas verdes após a reforma e a drenagem dos bairros antes alagadiços permitiram sua ocupação (NASCIMENTO; BERTRAND-KRAJEWSKI; BRITTO, 2013). O primeiro canal, que em parte corresponde à retificação do Rio do Soldado, foi inaugurado em agosto de $1907,{ }^{17}$ como ilustra a figura 5. A inovação deste projeto foi a separação total da rede de escoamento de águas pluviais e marés da rede de esgoto. Além de um sistema domiciliar de esgotos, todas as novas construções (a partir de 1907) deviam se adequar às normas da Comissão de Saneamento. Mesmo com as dificuldades da proximidade do lençol freático da superfície e a baixa declividade da Ilha de São Vicente, o projeto foi concluído e levou ao desaparecimento da epidemia em 1906.

Paralelamente à reforma, novos edifícios foram construídos na cidade: o novo prédio da Alfândega e o Teatro Guarany, ainda no final do século XIX, o mercado municipal, o novo prédio da Bolsa do Café, hotéis e cassinos na praia, como o Hotel Atlântico e o Parque Balneário, além da Ponte Pênsil, marcando uma nova arquitetura na cidade já modernizada, agora mais convidativa para os empresários e também para os turistas.

Foram também feitos loteamentos em antigas chácaras, como o bairro do Gonzaga, em que o próprio loteador, Mathias Costa, instalou uma linha de bonde que conectava o bairro ao centro da cidade. No início do século XX, até foi dada isenção de impostos para quem construísse ao longo das Avenidas Ana Costa e Conselheiro Nébias - que ligam o centro à orla -, demonstrando o interesse do Estado em incentivar a ocupação de novas áreas da cidade (SANTOS, 2008).

16 O jardim linear ao longo das Avenidas General Francisco Glicério e Afonso Pena nunca foi realizado.

17 O último canal foi inaugurado em 1927. 
Figura 4: Projeto de urbanismo de Saturnino de Brito.

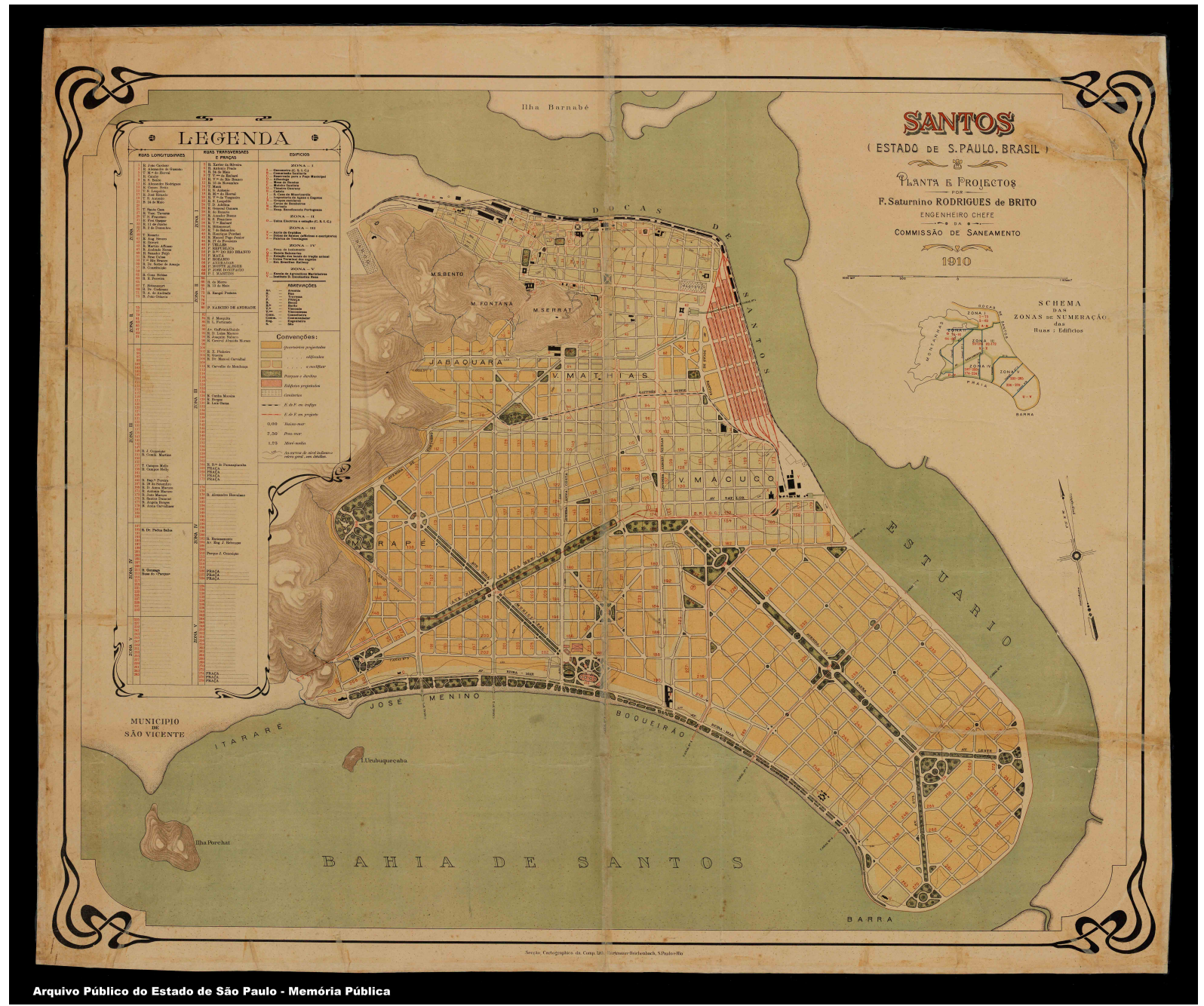

Fonte: Arquivo Público do Estado de São Paulo. 
Figura 5: Cerimônia de inauguração do Canal 1.

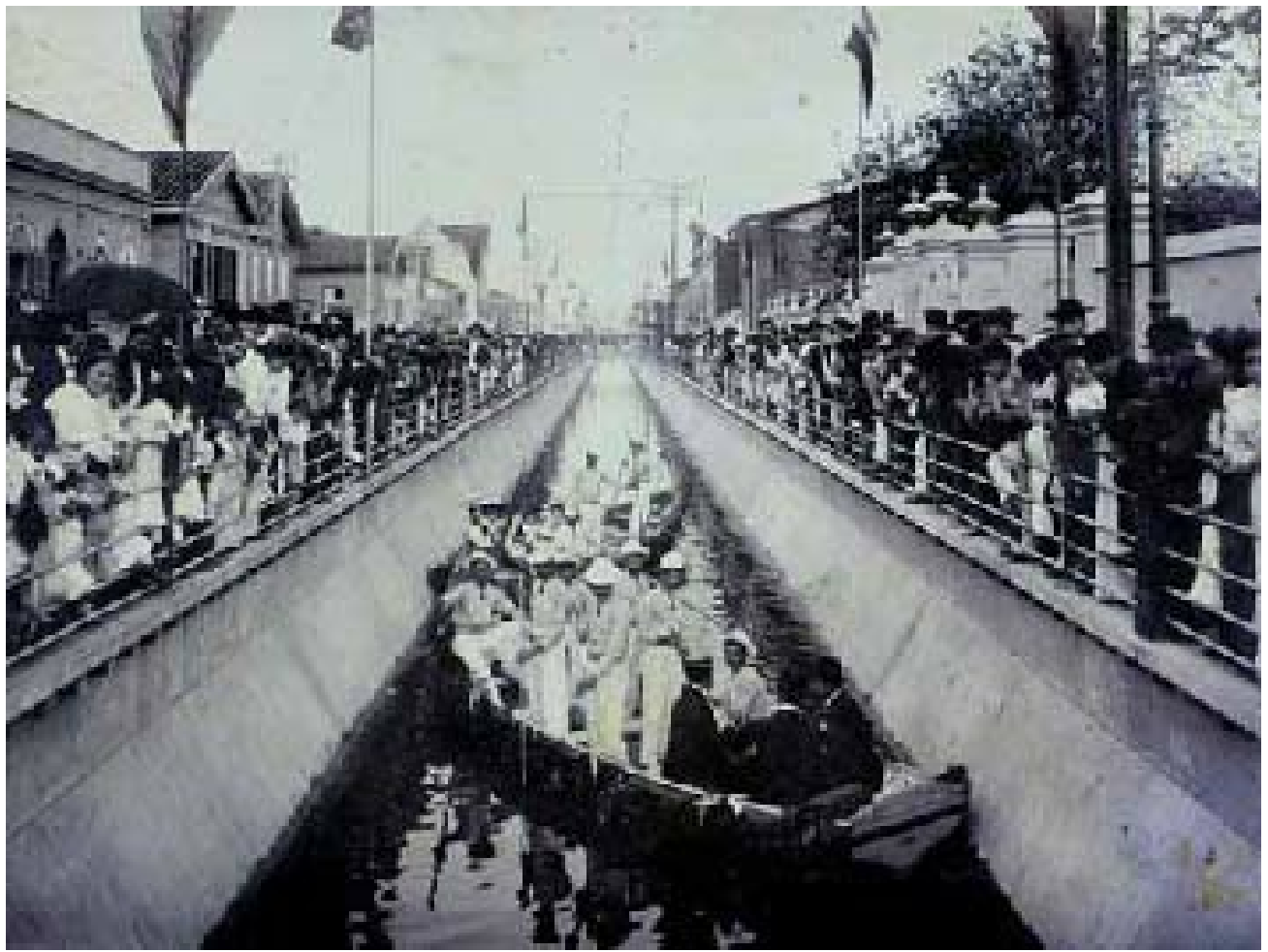

Fonte: Acervo da Fundação Arquivo e Memória de Santos apud Barbosa, 2000.

Figura 6: Cortiços existentes em Santos em 1889.

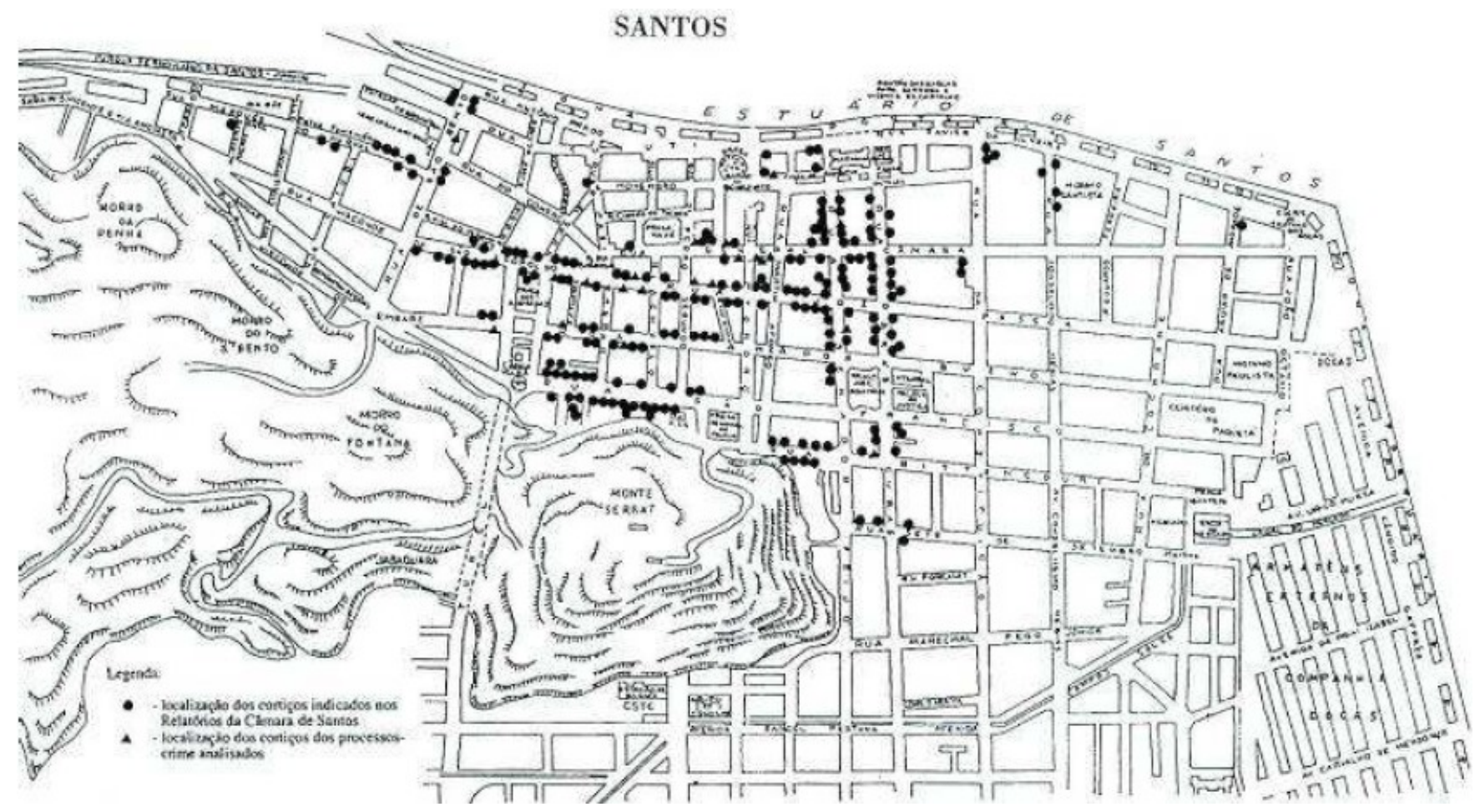

Fonte: Araújo Filho, J. R. 1969. 
Com isso, muitas famílias se juntaram àquelas que já haviam abandonado o centro e os bairros Valongo e Paquetá - por conta da alta incidência de doenças, como febre amarela e tuberculose - para residir nos novos bairros junto à orla. Assim sendo, os casarões desocupados foram transformados em habitações coletivas (figura 6): repartidas em cubículos, passaram a abrigar dezenas de famílias. "Em 1890, foram contados, pela municipalidade, 771 cortiços numa cidade que não tinha mais de 3.000 prédios no total, ou seja, pode-se estimar que pouco menos da metade de toda a população morava em cortiços." (SANTOS, 2008. p. 552). ${ }^{18}$ Contribuiu para acelerar esse processo um grande crescimento populacional: a cidade passou de 13 mil habitantes em 1890 para 50,4 mil em 1900 e quase 90 mil em 1913, sendo que mais de 40\% deles eram imigrantes (SANTOS, 2008). Como não havia disponibilidade de moradias em boas condições voltadas para os segmentos sociais de baixos rendimentos, não restavam muitas opções além dos cortiços, especialmente para os trabalhadores do porto. O crescimento do Porto de Santos, decorrente do aumento da exportação cafeeira, modificou a dinâmica do centro da cidade, com a abertura de muitos estabelecimentos ligados à produção e à comercialização de café e com a expansão do setor de comércio e serviços para atender aos novos habitantes.

É incontestável o rápido desenvolvimento que vai tendo esse importante Município, sua população cresce, e a cada dia mais se ressente da falta de casas; a cidade tende a estender-se necessariamente para o bairro do Quartel e em direção à barra. (Relatório apresentado à Câmara Municipal, em 30 de agosto de 1873. Arquivo Câmara Municipal de Santos, livro no 11. Apud LOPES, 1975, p. 43, grifo nosso). ${ }^{19}$

Em 1891, a Resolução Municipal no 37 proibiu a construção de cortiços e um relatório da Comissão de Serviço Sanitário de Santos, de 1898, descreveu a interdição de alguns cortiços:

Tomei interdictas varias habitações (...) Fiz evacuar alguns cortiços por cuja agglomeração de pessoas nelles existentes e suas más condições muito haveria a receiar. Procedi as devidas visitas domiciliares. Podero-vos que encontrei embaraços à minha acção. Tive necessidade de applicar a 2 indivíduos as penas da lei. Tive necessidade de requisitar praças para a garantia do serviço sanitário. (Relatório da Comissão de Serviço Sanitário de Santos, 1898. Arquivo do Estado de São Paulo, caixa 6820, manuscrito. Apud LOPES, 1975, p. 156).

18 Lanna (1995) aponta que esse levantamento realizado pela Prefeitura está incompleto, pois encontrou documentos sobre cortiços (em inquéritos policiais) que não constam dele e incluíam endereço, quantidade de residentes, estado de conservação do imóvel e nome do proprietário. Segundo o levantamento, destes 771 cortiços, 478 estavam em mau estado de conservação. Quanto aos proprietários, encontram-se no levantamento nomes de banqueiros, fazendeiros e comerciantes; muitos são proprietários de várias casas, processo que revela uma forma de manter a propriedade rentável enquanto realizam especulação imobiliária.

19 O Bairro dos Quartéis corresponde à área mais antiga do centro de Santos, e a barra aos bairros da orla, especialmente Gonzaga e Boqueirão nesse período. 
$\mathrm{Na}$ imprensa da época (tanto os jornais controlados pela Associação Comercial quanto os das associações operárias) apontava-se a necessidade de saneamento básico, guias para a população combater a febre amarela e também se encontram registros da gravidade do problema habitacional:

Queres hygiene, e ao mesmo tempo embellezamento da cidade? Mandai construir casas decentes para operários, por conta própria ou por meio de emprezas, e acabai com os cortiços, base de exploração, focos de epidemias, covil de immoralidades. (Jornal "O Operário" de 30 de outubro de 1892, p. 3. Apud LOPES, 1975, p. 124).

Nas duas primeiras décadas do século XX, com a melhoria da comunicação com os bairros da orla (abertura de amplas avenidas e da linha de bonde), muitas famílias mais abastadas deixaram o bairro do Paquetá e do Vila Nova para se instalar no Gonzaga e no Boqueirão, ou ao longo das Avenidas Ana Costa e Conselheiro Nébias. Os velhos casarões deixados para trás passaram a ser ocupados por famílias de classe média ou divididos em cômodos, formando cortiços: “(...) destaca-se nessa área o tipo de residência com porão alto e habitável, de maneira a alojar duas ou mais famílias ao mesmo tempo; muitas vezes, porém, este porão é utilizado para pequenas oficinas, ou mesmo bazares" (ARAÚJO FILHO, 1965, p. 62).

Um viajante hospedado em Santos relatou a vista de um cortiço que tinha de sua janela, aos fundos de uma padaria e uma refinadora de açúcar:

Nesse terreno um lodaçal negro e infecto, onde partiam lenha para o consumo do estabelecimento, havia um cortiço baixo de meia água, coberto com telha de zinco, igual a muitos outros espalhados pela podridão da urbe. Ali naquela área viviam em camaradagem (os habitantes eram em sua maioria estivadores), ou antes suportando-se, ... comendo no mesmo prato imundos restos de cozinha, o gato da padaria e grandes ratazanas... Da janela víamos serem retirados dos telheiros de zinco, que não passava disso o miserável e apertado cortiço, os doentes de febre amarela... que seus piedosos companheiros para ali carregavam para que tomassem um pouco de ar e que ali mesmo víamos morrer alguns momentos depois e que ficavam se decompondo a espera do carro fúnebre. (CASTAN, Scenas da abolição. São Paulo, 1924, p. 99-100, apud LANNA, 1995, p. 116)

Outro relatório da Comissão do Serviço Sanitário afirmava que a comissão contatava os proprietários dos cortiços para que fossem feitas melhorias e adaptações nos imóveis - para que cada cômodo tivesse ao menos uma fonte de ventilação e luz solar, ainda que somente uma claraboia -, e, no entanto, os proprietários não costumavam seguir suas orientações:

Se as casas são geralmente más, os proprietários e principais locatários as tornam ainda piores, pela gananciosa especulação a que se entregam. Assim é que, os armazéns, simplesmente cimentados e sem forro, o espaço entre o forro e o telhado, os corredores, os vãos das escadas, os porões subterrâneos 
enfim, qualquer espaço onde se possa colocar uma pequena cama ou esteira, tudo serve de moradia ou dormitório aos pobres jornaleiros com suas mulheres e filhos, sempre depauperados por outras privações ainda mais dolorosas... Os antros já descritos e os cortiços feitos à base de tábuas e cobertos de zinco têm sido interditados ou demolidos, mas têm também ocasionado a maior aglomeração em outras habitações que vão se transformando em casas de alugar cômodos sem possuir as condições exigidas. A maioria dos proprietários e arrendatários mostra-se refratária aos melhoramentos exigidos nas intimações... os proprietários desejando subtrair-se com sua família aos perigos das epidemias de febre amarela e varíola mudam-se para outras cidades e deixam suas propriedades alugadas a intermediários que as sublocam pelo maior preço possível, transformando casas em "cômodos para alugar" e onde as paredes de madeira ontem destruídas são, findas a inspeção, reconstruídas (Relatório da Comissão do Serviço Sanitário em Santos 1895, apud LANNA, 1995, p. 117-118).

Os relatos sobre os cortiços no final do século XIX mostram condições bastante similares às encontradas hoje: pouca ventilação, pouca iluminação, ambientes quentes e úmidos.

Houve, no final do século XIX, uma tentativa do poder público de resolver a questão habitacional; no entanto a empreitada não foi bem-sucedida e só ocorreu outra tentativa mais de 20 anos depois:

Tanto os inspetores da Comissão Sanitária quanto Saturnino de Brito apontavam, de forma recorrente a necessidade de construção de habitações operárias que eles chamavam de familistérios e/ou vilas operárias. Eram relativamente cuidadosos na solicitação de demolição dos cortiços alegando que a ausência de locais adequados para a remoção de seus habitantes era o grande problema. Acusavam a municipalidade de ineficiente por não providenciar a construção de habitações operárias. A Prefeitura celebrou um contrato, no início dos anos de 1890 para que fossem construídas pela Companhia Industrial de Santos, num espaço de três anos, 2.000 habitações higiênicas para proletários. Em contrapartida, a municipalidade seria obrigada a proibir a construção de cortiços e evitar a continuação dos que não tivessem condições satisfatórias de higiene. Entretanto alegando baixa lucratividade do investimento o contrato não foi cumprido (LANNA, 1995, p. 113-114).

Levando em consideração que em 1890 havia na cidade de Santos ao menos 2.654 edificações registradas em levantamento municipal, a construção de 2.000 casas certamente resolveria grande parte da questão habitacional. Elas seriam construídas na Rua São Francisco, a partir do sopé do Monte Serrat, em direção à Avenida Conselheiro Nébias, área próxima ao porto que até hoje concentra cortiços. Em 1914, a Companhia Santista de Habitações Econômicas realizou um projeto para construir 500 moradias na Vila Belmiro, voltadas para operários; no entanto, alegando baixa remuneração para o investimento, o projeto não se concretizou e apenas oito casas foram construídas.

Na década seguinte, com a crise do café a partir de 1929, a cidade passou por grande 
empobrecimento, seu centro sofreu modificações e algumas pequenas indústrias ligadas ao café fecharam ou reduziram sua produção, como as de confecção de sacas e de moagem dos grãos.

$\mathrm{Na}$ orla, muitos dos casarões, que na maioria pertenciam a comissários e fazendeiros, foram vendidos e transformados em pensões que hospedavam as famílias do planalto nos fins de semana e nas férias. Mas a crise econômica da década de 1930 na cidade não durou muito: a industrialização, com destaque para o polo industrial de Cubatão, atraiu migrantes de outras regiões do país, que se instalaram em favelas nos morros e nas áreas de mangue e restinga ou em cortiços no centro.

Por outro lado, com as grandes avenidas abertas pelo projeto urbanístico de Saturnino Brito no início do século XX e o desprendimento da locomoção dos antigos rígidos trilhos de bondes com sua substituição pelos ônibus, teve início o processo de formação de novos bairros e de subcentros na cidade. Com a abertura da Rodovia Anchieta em 1947, aumentou o número de turistas e de atividades econômicas voltadas para o atendimento a esse público, crescendo o comércio e os serviços próximos às praias. $\mathrm{O}$ surgimento de centros comerciais, galerias e - mais tardiamente - shopping centers atraíram ainda mais os estratos de rendimentos médios e altos para bairros como Aparecida, Gonzaga, Ponta da Praia e Boqueirão.

Assim, a área central deixou de receber atividades geradoras de maior fluxo e consumidores de alta renda e, entre outras coisas, por conta da diminuição na arrecadação de impostos na área, não houve a adequação necessária desse espaço que passou a ter atuação do poder público reduzida em detrimento de outros lugares da cidade (SANTOS, 2008, p.17).

Nas décadas de 1950 e 1960 foram construídos vários prédios próximos à orla da praia, destinados à venda como segundas residências, o que causou a redução da ocupação de pequenos hotéis e pensões nesses bairros (SEABRA, 1979). Isto resultou em uma enorme desigualdade na cidade: de um lado, várias famílias morando em espaços pequenos, compartilhando com outras famílias o uso do sanitário e do quintal, e, de outro, apartamentos que ficavam vazios na maior parte do ano.

[o] fenômeno da "segunda residência", altamente disseminado em longos espaços dos entornos das capitais estaduais e das grandes aglomerações do litoral brasileiro. Tais residências de veraneio podem ser apontadas como o fator numericamente mais expressivo da urbanização litorânea, pois ocorrem ao longo de toda a costa, revelando um dinamismo que se mantém (obviamente em ritmo menor) mesmo em períodos de crise acentuada do setor da construção civil no país. O caráter impactante da atividade de 
veraneio é, em termos ambientais, diretamente relacionado à capacidade dos poderes públicos de ordenarem o uso do solo. Em termos sociais, tal atividade desorganiza em muito a sociabilidade dos locais onde se instala, ao inaugurar um mercado de terras ascensional e ávido, gerando uma situação fundiária tensa e conflitiva. (MORAES, 1999, p. 38-39).

$\mathrm{Na}$ figura 7 vemos o primeiro palacete na Praia José Menino, construído em 1900 por Belmiro

Ribeiro e derrubado em 1963 para a construção de um edifício; pode-se observar no canto direito a placa de divulgação do empreendimento que seria construído.

Paralelamente à construção dos prédios de segunda residência, a situação dos cortiços e de outras moradias precárias permanecia grave, pressionada pelo aumento populacional. Entre 1920 e 1965, Santos passou de pouco mais de 100 mil habitantes para 280 mil; assim, novos bairros foram formados, e a cidade, que já tinha crescido em direção ao sul (a orla), passou a se expandir em direção ao oeste, mas de forma pouco ordenada:

Enquanto na parte oriental, a expansão foi-se fazendo dentro de certa diretriz administrativa, onde tanto a Prefeitura como a Comissão do Saneamento iam seguindo de perto as áreas em crescimento, na parte ocidental houve como que um tumultuamento na ampliação do sítio urbano, onde os loteamentos e as formações das "vilas" não obedeceram às posturas municipais. Por outro lado, os poderes públicos de São Vicente e de Santos não se fizeram presentes nessa expansão, a não ser para a cobrança dos impostos (ARAÚJO FILHO, 1965, p. 22).

Figura 7: Primeiro palacete na Praia José Menino, antes de sua demolição em 1963.

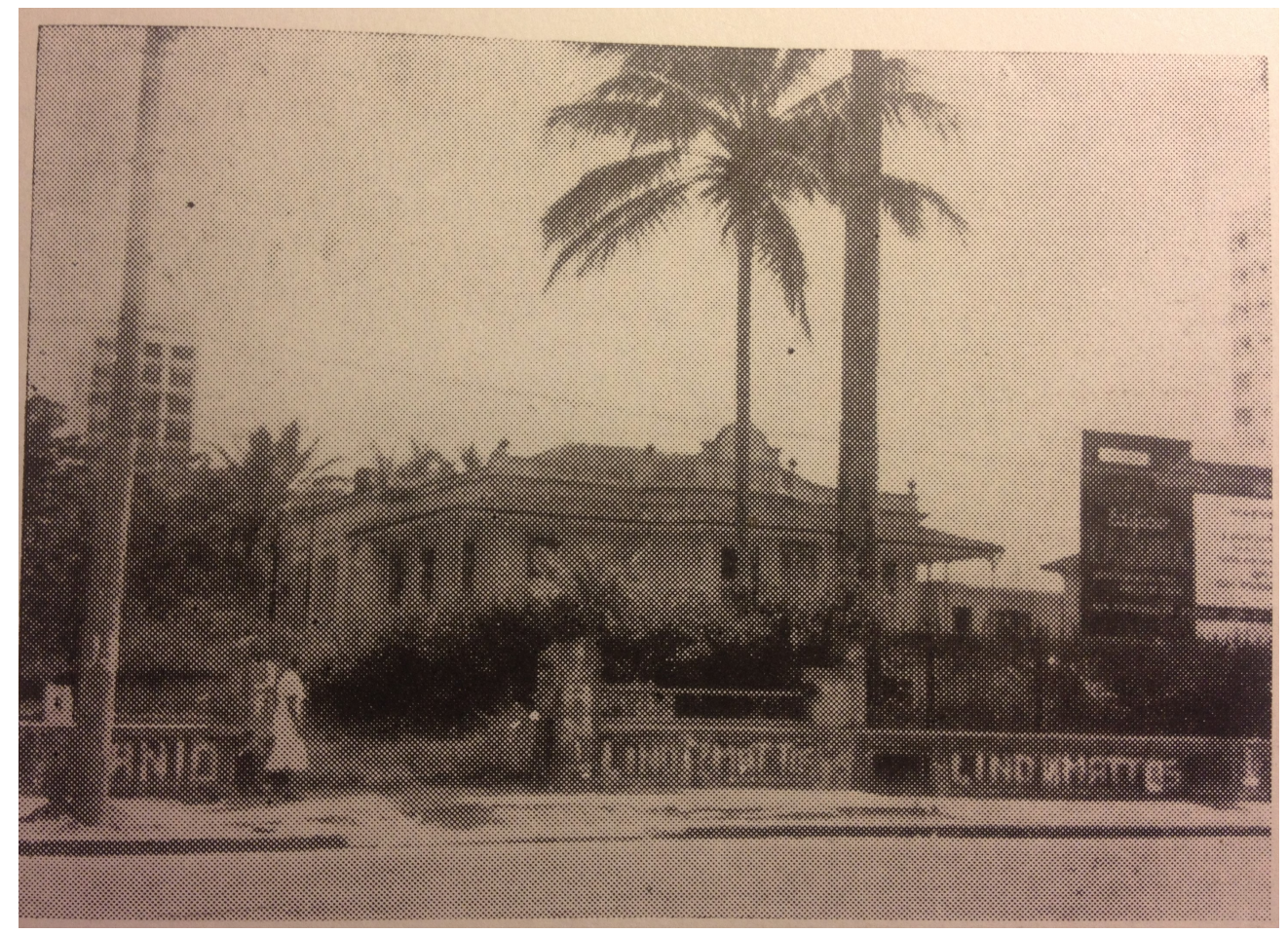

Fonte: Araújo Filho, 1965. 
Outras áreas de habitações precárias são os morros próximos ao centro: Morro da Penha, Morro de São Bento, Morro do Fontana e Monte Serrat. A construção de casas nos morros teve início no final do século XIX, realizada principalmente por imigrantes italianos; mas, como essa população era proveniente de regiões montanhosas, tinha técnicas construtivas adaptadas a esse tipo de terreno. As construções mais precárias surgiram a partir da década de 1940, quando migrantes de outras regiões brasileiras foram atraídos pelos empregos na indústria. Esses bairros são sujeitos a deslizamentos durante períodos de alta pluviosidade: o primeiro verão com casos graves foi em 1928, no qual parte da Santa Casa de Misericórdia, situada ao sopé do Monte Serrat, foi destruída, além de várias casas. Em 1953 foi fundada a primeira Sociedade de Melhoramentos dos Morros, no Morro São Bento, reivindicando melhorias, ações de saúde pública (a população dos bairros sofria com esquistossomose). Uma década depois já havia 11 sociedades organizadas pressionando o poder público. No entanto, Araújo Filho (1965) aponta que a situação dos morros ainda era melhor do que a dos bairros a oeste, que frequentemente estavam em áreas de mangues, pois os morros possuíam serviços de água, esgoto e iluminação e escolas primárias. As maiores dificuldades eram de circulação e ausência de equipamentos de saúde, pois possuíam comércio e alguns artigos eram trazidos por ambulantes do centro diariamente, como o pão. A população desses bairros em 1963 era estimada em 30 mil pessoas. 
Figura 8: Formação dos bairros em Santos e São Vicente.

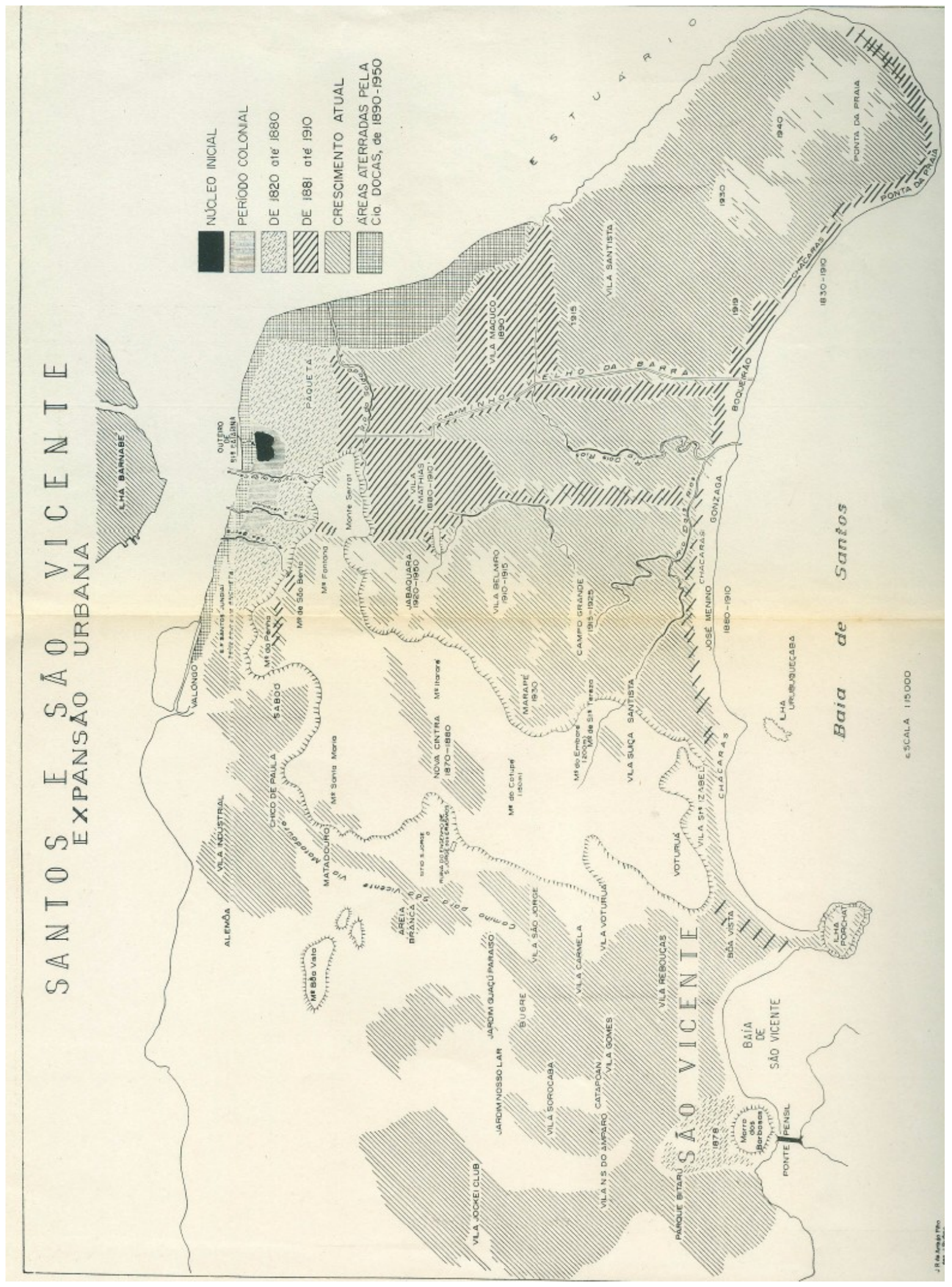

Fonte: Araújo Filho, 1965. 
Figura 9: Morro da Penha, Santos-SP.

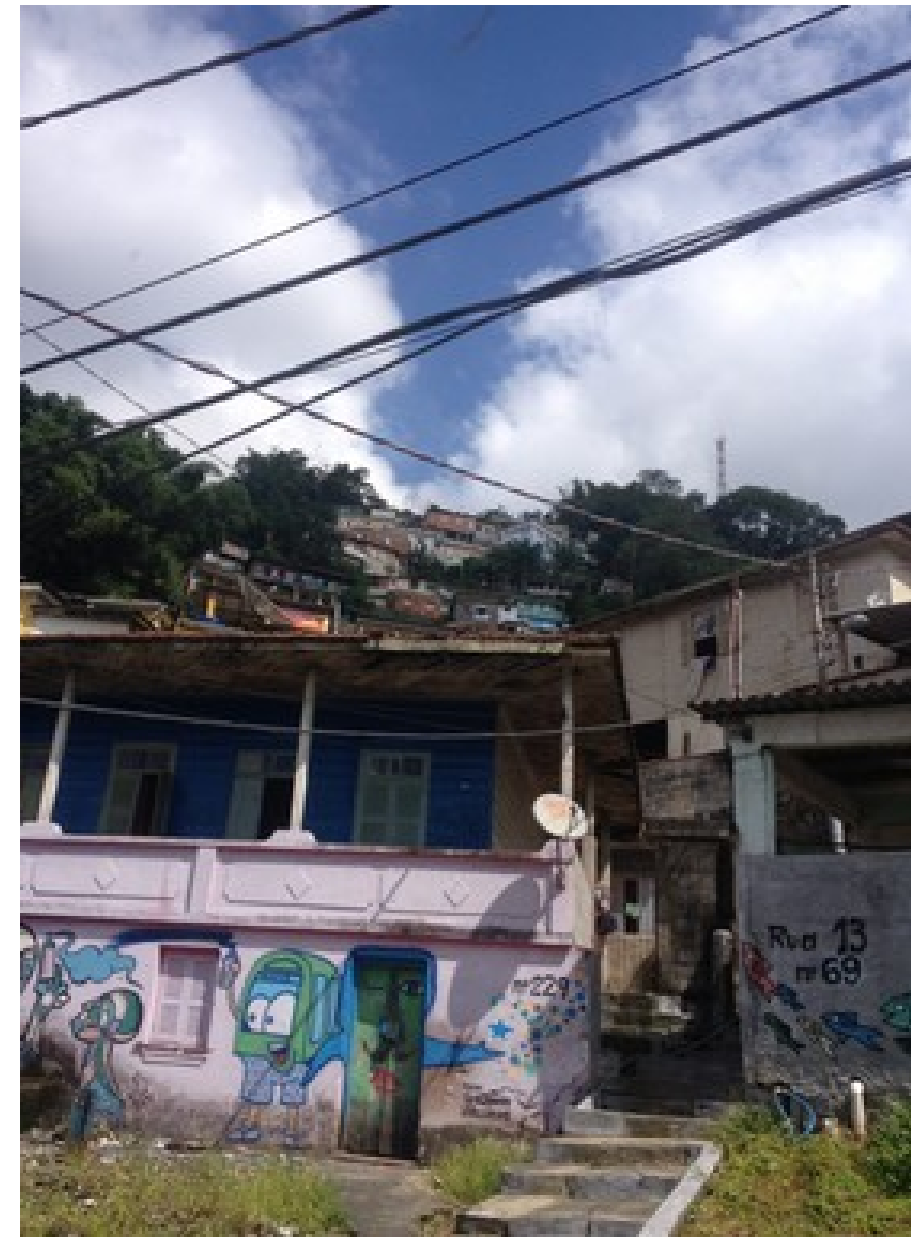

Fonte: Bruna G. Eskinazi - abril de 2017.

Na década de 1970, apesar do grande crescimento econômico, industrial e portuário do país, houve um crescimento da pobreza com grande arrocho econômico. Em Santos, a população passou de 280 mil em 1965 para 345 mil em 1970, aumentado o deficit habitacional e também a informalidade dos aluguéis, já que o Plano Diretor de 1968 não permitia o uso residencial nos bairros centrais.

A crise econômica das décadas de 1980 e 1990 trouxe desemprego e informalidade, a taxas que chegaram a, respectivamente, $22,1 \%$ e $29,2 \%$ no final dos anos 1990. Com isso, aumentou a população que morava em habitações precárias. De acordo com estimativas realizadas pela Prefeitura, em 1990 existiam 840 habitações coletivas de aluguel precárias na cidade (SANTOS, 2008).

Os cortiços que se concentravam no centro no final do século XIX se deslocaram nos anos 1950 para o bairro Valongo, e nos anos 1970 para o Paquetá, chegando até o Vila Nova nos anos 2000 . 
Figura 10: Evolução de domicílios encortiçados nos bairros centrais de Santos-SP.

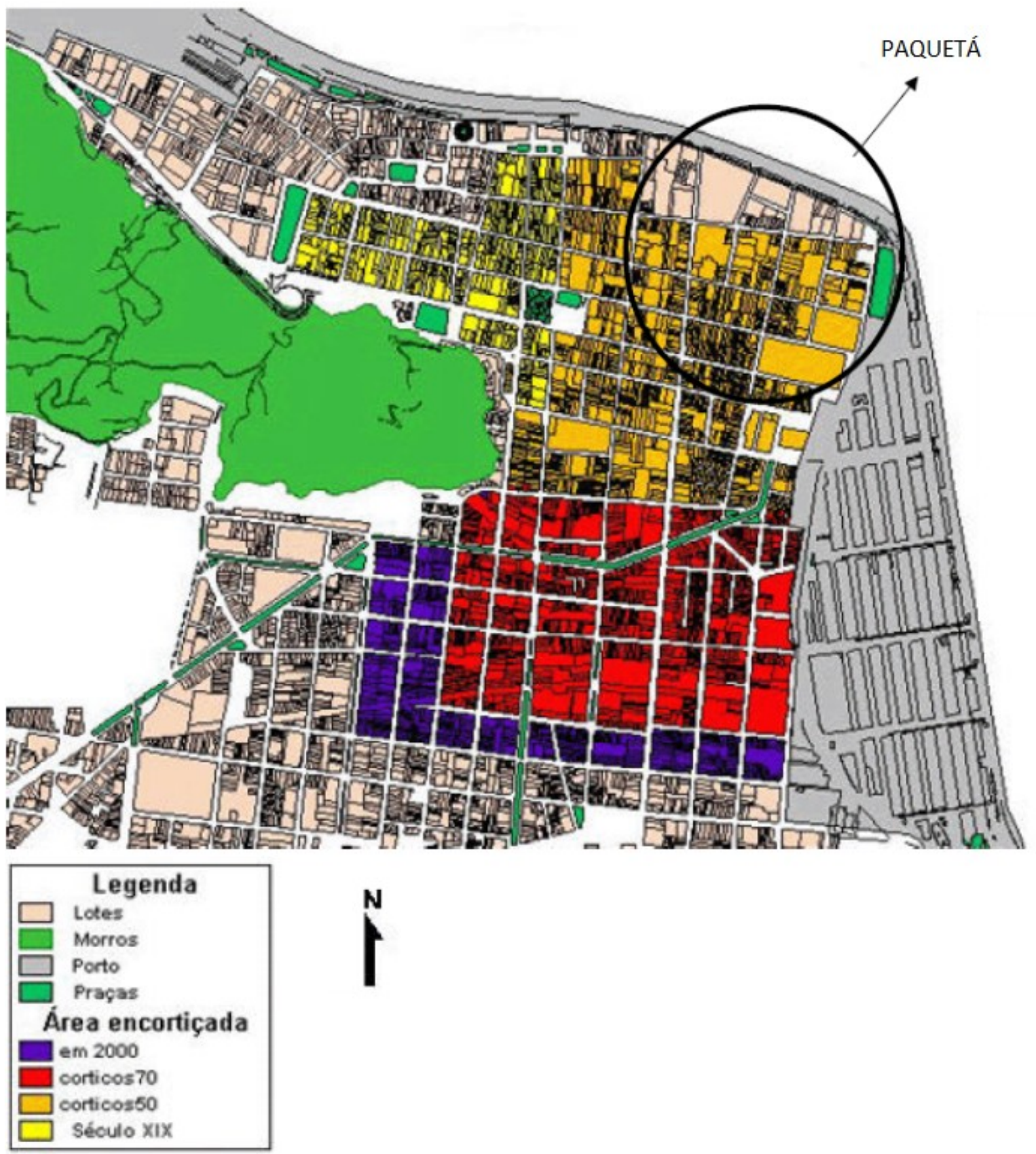

Fonte: Material cedido pelo Escritório Alegra Centro.

Atualmente a situação dos cortiços continua preocupante. Um acidente ocorrido em 2016 atesta a má condição das construções: parte da parede de duas casas geminadas caiu em cima da fiação elétrica e de um carro no bairro Vila Nova, nas proximidades da APC 2. Conforme depoimento de um agente da defesa civil, "a condição é bem precária e insalubre, como são nos cortiços. Eles dizem que pagavam aluguel e a responsabilidade (pela manutenção da 
estrutura do imóvel) é do proprietário. Existem outras casas na rua em situações ruins, mas essas realmente estão em pior estado" (MÜLLER, 2016). Nenhum dos moradores, dentre as sete famílias, ficou ferido, no entanto fica evidente o descaso do proprietário do cortiço com as condições das casas, ignorando até mesmo intimação anterior da Prefeitura para a reforma da área. Dois casos similares aconteceram em 2011: uma marquise caiu, acarretando a morte de um pedestre, e a fachada de um sobrado desabou sobre carros estacionados. Em 2017, uma laje de um imóvel interditado caiu sobre um trabalhador que iniciava a limpeza dos entulhos para a posterior demolição (MARTINEZ, 2017b). Em fevereiro de 2018, parte da parede de um casarão caiu sobre a calçada.

Estes foram casos extremos, porém não são isolados, pois são recorrentes as queixas de moradores por falta de manutenção e problemas diversos, como goteiras. Segundo relato de uma trabalhadora da padaria da ACC, o quarto que aluga tem goteiras durante as chuvas fortes, e ela já chegou a perder objetos por causa da água, além de ter que se hospedar com parentes durante alguns dias; isso apesar do alto valor do aluguel, que chega a quase um salário-mínimo. ${ }^{20}$

Os quartinhos com telha de zinco comumente encontrados nos quintais dos cortiços para aumentar o número de moradores são alojamentos mais baratos (de R \$ 350 a R \$ 400) do que os que ficam dentro da casa. São também mais quentes, menos ventilados e sofrem mais riscos, como de incêndios por causa da fiação improvisada. ${ }^{21}$

O Índice Paulista de Vulnerabilidade Social (IPVS), ${ }^{22}$ compilado pela Fundação Seade, com base nos dados do Censo de 2010, mapeia a enorme desigualdade espacial na cidade de Santos e mostra como nos bairros centrais predomina a população em situações de vulnerabilidade. O IPVS divide os domicílios urbanos em seis grupos, de baixíssima vulnerabilidade a vulnerabilidade muito alta. ${ }^{23}$

20 O salário-mínimo no Brasil em 2017 era de R\$ 937,00.

21 A figura 39, no capítulo 4, mostra um desses quartos após a saída da inquilina, com grandes marcas de umidade na parede.

22 Este índice analisa a renda domiciliar per capita, o rendimento médio da mulher responsável pelo domicílio, a porcentagem de domicílios com renda domiciliar per capita de até $1 / 2$ salário-mínimo, a porcentagem de domicílios com renda domiciliar per capita de até 1/4 salário-mínimo, a porcentagem de pessoas responsáveis pelo domicílio que são alfabetizadas, a porcentagem de pessoas responsáveis de 10 a 29 anos, a porcentagem de mulheres responsáveis de 10 a 29 anos, a idade média das pessoas responsáveis e a porcentagem de crianças entre 0 e 5 anos (SEADE, 2013).

$23 \mathrm{O}$ Grupo 4 (vulnerabilidade média - setores urbanos) soma 36.366 pessoas (8,7\% do total). No espaço ocupado por esses setores censitários, o rendimento nominal médio dos domicílios era de R\$ 1.760 e em $20 \%$ deles a renda não ultrapassava meio salário-mínimo per capita. Com relação aos indicadores demográficos, a idade média dos responsáveis pelos domicílios era de 48 anos e aqueles com menos de 30 anos representavam 
Os grupos com vulnerabilidade média, alta e muito alta representam $16,5 \%$ da população total de Santos, e estão distribuídas principalmente nas regiões centrais e noroeste da cidade, como se pode observar na figura 10.

Figura 10: Distribuição do Índice Paulista de Vulnerabilidade Social - Santos, 2010.

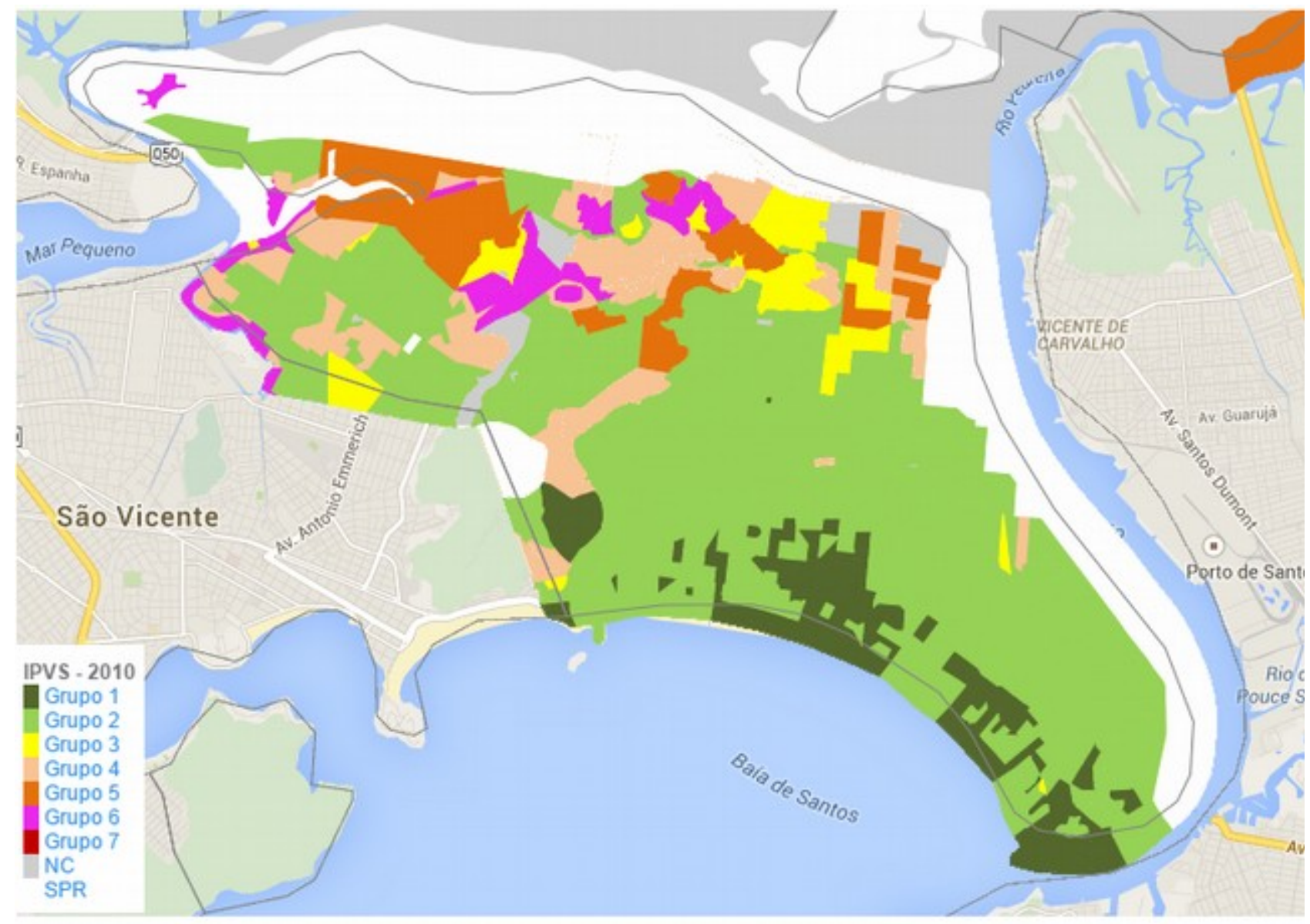

Fonte: Fundação Seade.

Ainda que a população em situação de vulnerabilidade seja bastante expressiva, é importante ressaltar que houve um esvaziamento de população residente nos bairros centrais de Santos

10,6\%. Dentre as mulheres chefes de domicílios 9,8\% tinham até 30 anos, e a parcela de crianças com menos de seis anos equivalia a 8,5\% do total da população desse grupo. O Grupo 5 (vulnerabilidade alta - setores urbanos) reúne 9.855 pessoas (2,4\% do total). No espaço ocupado por esses setores censitários, o rendimento nominal médio dos domicílios era de R $\$ 1.512$ e em 23,3\% deles a renda não ultrapassava meio salário-mínimo per capita. Com relação aos indicadores demográficos, a idade média dos responsáveis pelos domicílios era de 43 anos e aqueles com menos de 30 anos representavam 20,8\%. Dentre as mulheres chefes de domicílios 21,2\% tinham até 30 anos, e a parcela de crianças com menos de seis anos equivalia a $11 \%$ do total da população desse grupo. O Grupo 6 (vulnerabilidade muito alta - aglomerados subnormais) inclui 22.433 pessoas (5,4\% do total). No espaço ocupado por esses setores censitários, o rendimento nominal médio dos domicílios era de R\$1.185 e em 34,4\% deles a renda não ultrapassava meio salário-mínimo per capita. Com relação aos indicadores demográficos, a idade média dos responsáveis pelos domicílios era de 41 anos e aqueles com menos de 30 anos representavam 23\%. Dentre as mulheres chefes de domicílios 24,5\% tinham até 30 anos, e a parcela de crianças com menos de seis anos equivalia a $12,1 \%$ do total da população desse grupo (SEADE, s/d). 
(incluindo Centro, Valongo, Paquetá, Vila Nova e Monte Serrat), que passaram de 44 mil habitantes em 1950 para 4,3 mil em 2010, ${ }^{24}$ enquanto, de forma geral, a população da cidade mais que dobrou no período. Uma das possíveis causas para essa mudança foi a proibição, no Plano Diretor de 1968, de residências no centro da cidade. ${ }^{25}$ Além disso, a falta de investimentos públicos no centro contribuiu para que somente aqueles que não tinham opções melhores de moradia e os que precisavam ficar perto de seus locais de trabalho na região permanecessem nos bairros centrais. Uma quantidade muito grande dessa população reside em cortiços.

As políticas do Estado em relação à habitação iniciaram-se em Santos com as Caixas de Pensão e Aposentadoria (criadas em 1926 pela Lei Elói Chaves) e com os conjuntos habitacionais dos Institutos de Aposentadorias e Pensões (IAPs) na década de 1940. Na década de 1960 iniciou-se a construção do primeiro conjunto habitacional do Banco Nacional de Habitação (BNH), no bairro Aparecida, cujos primeiros moradores chegaram em 1970.

A Companhia de Desenvolvimento Habitacional e Urbano (CDHU) também realizou empreendimentos na cidade, alguns ligados a seu Programa de Atuação em Cortiços, no centro, com 113 unidades habitacionais. Esses projetos serão vistos com mais detalhes no próximo capítulo.

Em 1992, pela precariedade das moradias no centro e pelos baixos indicadores sociais - além dos problemas habitacionais nas periferias -, elaborou-se um Plano Diretor que definiu Zonas Especiais de Interesse Social. Foi o primeiro em Santos a utilizar-se do zoneamento para inverter a alocação de recursos para minimizar as desigualdades sociais e a criar conselhos municipais, para que a população tivesse uma participação mais efetiva nas políticas urbanas.

Este zoneamento é chamado de "inversão de prioridades":

A preocupação central de um zoneamento de prioridades e "includente", em contraste com a técnica tradicional de zoneamento de uso do solo, não é a separação de funções e usos, mas sim a identificação dos espaços residenciais dos pobres urbanos e sua classificação de acordo com a natureza do assentamento (favela ou loteamento irregular) e, adicionalmente, conforme o grau de carência de infra-estrutura apresentado. Convencionouse chamar esses espaços de Áreas de Especial Interesse Social (AEIS) ou Zonas Especiais de Interesse Social (ZEIS) (SOUZA, 2002, p. 263).

Esse Plano Diretor, elaborado no governo municipal de Telma de Souza (do Partido dos

24 Levantamento realizado pela Seção Escritório Técnico Alegra Centro (Setac) com base em dados do Censo do IBGE.

25 Este Plano Diretor estabelece um zoneamento que não permite habitações nos bairros Centro, Valongo e Paquetá, e nas porções leste dos bairros Vila Nova e Vila Mathias. 
Trabalhadores, cuja gestão foi de 1989 a 1992), determinou o zoneamento de prioridades de três tipos: a Zeis 1, que correspondia a áreas ocupadas irregularmente; a Zeis 2, de áreas não ocupadas; e a Zeis 3, de áreas de concentração de cortiços nos bairros centrais deteriorados. Estruturando, assim, a intervenção pública de acordo com as necessidades de moradia de interesse social, normatizando a questão fundiária, a partilha do solo urbano e mecanismos financeiros próprios para o acesso à moradia popular (SANTOS, 2008).

De acordo com levantamento realizado pela Cohab-ST (Companhia de Habitação da Baixada Santista) em 1996, em 19 das 24 quadras que compunham a Zeis 3 no Paquetá na época, ${ }^{26}$ foram pesquisados 466 imóveis, dos quais 142 foram classificados como cortiços. ${ }^{27}$ Em cada imóvel habitavam em média 22,52 pessoas, chegando ao total de 3.154 pessoas (BRAGA, 2004). Em 2000, a CDHU encomendou a uma empresa de consultoria uma pesquisa no perímetro da Zeis 3 e foram localizados 328 cortiços (CDHU, 2006). O levantamento feito pela Prefeitura de Santos em 2010, que consta na lei do Alegra Centro Habitação (será detalhado mais adiante, no anexo I), localizou 221 cortiços, dos quais 71 se encontram fora do perímetro de Zeis 3. Segundo levantamento da Secretaria de Desenvolvimento Urbano (Sedurb) da Prefeitura, entre 1985 e 2014 o número de residências regulares nas Áreas de Proteção Cultural caiu de 1.538 para 835, mas os cortiços aumentaram, de 51 para 183. Os censos realizados pelo IBGE não contabilizam o número de imóveis que funcionam como cortiços, e sim o número de domicílios nas habitações coletivas. No Censo de 2000 foram contabilizados 2.590 cômodos; já no Censo de 2010 a cifra caiu para 1.692. Podemos traçar algumas hipóteses sobre a disparidade entre os dados: 1) existe uma dificuldade muito grande para os técnicos que realizam as pesquisas averiguarem com precisão o número de famílias que moram em cada cortiço, e quais imóveis estão sendo ocupados dessa forma, e as metodologias das pesquisas são diferentes; 2) há um aumento do número de cortiços em bairros que não têm esse tipo de moradia como predominante e as pesquisas, portanto, não têm essas áreas como foco; 3) há uma migração de famílias moradoras de cortiços para outros bairros (zona noroeste, morros, zona continental) e outros municípios da Baixada Santista (São Vicente, Guarujá, Cubatão). Foram vistas em trabalhos de campo placas de "Aluga-se Quartos" em imóveis que não estão mapeados como cortiços nem no relatório da CDHU nem no anexo da legislação de 2010 da Prefeitura.

26 A Zeis 3 teve seu perímetro aumentado na Lei Complementar nº 646, de 30 de dezembro de 2008.

27 A Prefeitura de Santos utilizou o mesmo conceito de cortiço da Lei n ${ }^{\circ} 10.928$, de 08/01/1991, da Prefeitura Municipal de São Paulo, conhecida como Lei Moura. 
Em 2003, a Prefeitura de Santos realizou em parceria com a Cohab-ST um Censo dos moradores de cortiços, tendo entrevistado na ocasião 1.238 moradores de cortiços dos bairros Vila Nova e Paquetá, o que representava uma amostra de 8,53\% dos 14.500 moradores de cortiços estimados naquela época. O Quadro 1 apresenta alguns dos dados coletados por esta pesquisa.

$68 \%$ das famílias tem até 3 pessoas, por este motivo os empreedimentos de HIS voltados para moradores de cortiços têm apartamentos com um dormitório. Essa população é bastante jovem (60\% com até 29 anos) e com maior proporção de mulheres $(54,7 \%)$. Apenas 23\% concluíram o ensino fundamental e $10 \%$ não são alfabetizados, por um lado a baixa escolaridade desta população pode ser relacionada com a alta taxa de informalidade no trabalho e a dificuldade de comprovar renda, portanto a informalidade dos contratos de locação típicos dos cortiços. De outro lado, a própria condição de moradia precária influi negativamente no desempenho escolar das crianças e aumenta a evasão escolar. A pesquisa realizada por Kohara (2009) com crianças moradoras de cortiços no bairro do Glicério em São Paulo, concluiu que elas têm índices de reprovação e de evasão quase três vezes maior que a média do município. Como motivos aponta o número menor de camas no domicílio do que o número de moradores, prejudicando a qualidade do sono, falta de mobiliário (como mesa e cadeira), falta de janela e frequente mudança de domicílio.

Quadro 1: Dados do Censo dos Moradores de Cortiços - 2003

\begin{tabular}{|c|c|c|c|c|c|c|c|}
\hline \multicolumn{8}{|c|}{ Dados do Censo dos Moradores de Cortiços - 2003} \\
\hline \multirow{2}{*}{ População por faixa etária } & 0 a 9 anos & 10 a 19 anos & 20 a 29 anos & 30 a 39 anos & 40 a 49 anos & 50 a 59 anos & acima de 60 anos \\
\hline & $24 \%$ & $17 \%$ & $19 \%$ & $14 \%$ & $11 \%$ & $8 \%$ & $7 \%$ \\
\hline \multirow{2}{*}{ Número de pessoas por família } & 1 pessoa & 2 pessoas & 3 pessoas & 4 pessoas & 5 pessoas & 6 pessoas & acima de 7 pessoas \\
\hline & $23 \%$ & $24 \%$ & $21 \%$ & $14 \%$ & $8 \%$ & $5 \%$ & $5 \%$ \\
\hline \multirow{2}{*}{ Escolaridade do chefe da família } & analfabeto & EF incompleto & EF completo & EM incompleto & EM completo & Ensino Superior & \\
\hline & $10 \%$ & $67 \%$ & $13 \%$ & $3 \%$ & $6 \%$ & $1 \%$ & \\
\hline \multirow{2}{*}{$\begin{array}{l}\text { Vínculo empregatício do chefe da } \\
\text { família }\end{array}$} & $\begin{array}{l}\text { assalariado } \\
\text { com registro }\end{array}$ & $\begin{array}{l}\text { trabalho } \\
\text { informal }\end{array}$ & aposentado & autônomo & sem renda & & \\
\hline & $47 \%$ & $46 \%$ & $3 \%$ & $2 \%$ & 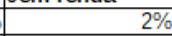 & & \\
\hline \multirow{2}{*}{ Renda por família } & até $\mathrm{R} \$ 50$ & $R \$ 51$ a $R \$ 100$ & $R \$ 101$ a $R \$ 150$ & $\mathrm{R} \$ 151$ a $\mathrm{R} \$ 200$ & $R \$ 201$ a $R \$ 300$ & $\mathrm{R} \$ 301$ a $\mathrm{R} \$ 400$ & acima de $\mathrm{R} \$ 400$ \\
\hline & $7 \%$ & $6 \%$ & $9 \%$ & $18 \%$ & $17 \%$ & $16 \%$ & $27 \%$ \\
\hline \multirow{2}{*}{ Renda per capita das famílias } & $\mathrm{R} \$ 51$ a $\mathrm{R} \$ 100$ & $\mathrm{R} \$ 101$ a $\mathrm{R} \$ 150$ & $\mathrm{R} \$ 151$ a $\mathrm{R} \$ 200$ & $\mathrm{R} \$ 201$ a $\mathrm{R} \$ 300$ & $\mathrm{R} \$ 301$ a $\mathrm{R} \$ 400$ & $\mathrm{R} \$ 401$ a R\$500 & \\
\hline & $4 \%$ & $8 \%$ & $16 \%$ & $22 \%$ & $21 \%$ & $29 \%$ & \\
\hline \multirow{2}{*}{ Despesa com aluguel por família } & sem aluguel & $\mathrm{R} \$ 10$ a $\mathrm{R} \$ 100$ & $\mathrm{R} \$ 101$ a $\mathrm{R} \$ 150$ & $\mathrm{R} \$ 151$ a $\mathrm{R} \$ 200$ & $\mathrm{R} \$ 201$ a $\mathrm{R} \$ 300$ & $\mathrm{R} \$ 301$ a $\mathrm{R} \$ 400$ & acima de $\mathrm{R} \$ 400$ \\
\hline & $23 \%$ & $7 \%$ & $19 \%$ & $25 \%$ & $17 \%$ & $3 \%$ & $6 \%$ \\
\hline \multirow{2}{*}{ Número de famílias por cortiço } & 1 a 3 famílias & 4 a 6 famílias & 7 a 9 famílias & 10 a 12 famílias & 13 a 15 famílias & 16 a 24 famílias & \\
\hline & $17 \%$ & $34 \%$ & $19 \%$ & $15 \%$ & $6 \%$ & $9 \%$ & \\
\hline
\end{tabular}

Fonte: cedido pela CDHU, organização nossa.

Considerando que em 2003 o salário-mínimo era de $\mathrm{R} \$ 240,00$, vemos que ao menos 40\% das famílias recebia menos que o salário-mínimo e que as despesas com aluguel eram bastante significativas. Outros dados relevantes apontados pela pesquisa: 43\% dos entrevistados morava há apenas um ano naquele domicílio, mas 35\% morava no mesmo bairro há mais de 
10 anos, indicando a grande rotatividade entre cortiços, mas a permanência nos bairros. 30\% dos moradores eram migrantes nordestinos. A profissão mais comum era em serviços de limpeza (25\%), seguido de trabalhos na construção civil (11\%) e no comércio (10\%). 56\% responderam que iam ao trabalho a pé, $26 \%$ de ônibus e $16 \%$ de bicicleta, um indicador muito importante da preferência e resistência desses moradores em se manter morando no centro, $72 \%$ não tem despesas com transporte.

Na Zeis 1, a regularização jurídica e urbanística foi bem-sucedida e as famílias moradoras das áreas irregulares tiveram concessão de uso (caso o terreno fosse público) e apoio técnico para aquisição do terreno (caso fosse de particulares). Na segunda Zeis foram criados empreendimentos habitacionais e divisão de lotes em terrenos não ocupados, com a determinação de que ao menos $50 \%$ das unidades habitacionais a serem produzidas deveriam ser destinadas a famílias cuja renda fosse inferior a 5 salários-mínimos. Nas Zeis 2, durante o período de 1989 (quando se iniciou a elaboração do Plano Diretor) a 1998, a Cohab-ST produziu 242 unidades habitacionais e financiou a aquisição de 1.113 lotes urbanizados; também houve um empreendimento financiado pela CDHU, de 504 apartamentos. Os detalhes dessa produção habitacional serão discutidos no próximo capítulo.

Já as ações para a terceira Zeis não tiveram grandes resultados. Foi feito um grande levantamento sobre a situação das áreas encortiçadas do centro da cidade, mas as intervenções públicas mostraram-se muito difíceis de serem realizadas sem a colaboração dos proprietários dos cortiços. A legislação determina os objetivos para a Zeis 3, mas não especifica como serão cumpridos:

Art. 39. A criação da Zona Especial de Interesse Social 3 - ZEIS 3 tem por objetivos

I - fixar os moradores da área delimitada como Zona Especial de Interesse Social 3 - ZEIS 3 através de mecanismos que impeçam processos de expulsão;

II - melhorar as condições sanitárias e de segurança das habitações coletivas precárias de aluguel (cortiços), através de incentivos para obras de recuperação;

III - incentivar a produção de unidades habitacionais destinadas à população de baixa renda com a introdução de mecanismos de compensação;

IV - revitalizar áreas degradadas através de recuperação ou renovação do conjunto arquitetônico existente na Zona Especial de Interesse Social 3 Zeis 3. (Prefeitura Municipal de Santos, Lei Complementar $n^{\circ}$ 53, de 15 de maio de 1992).

É importante notar que a legislação não especifica quais são os mecanismos que permitiriam impedir processos de expulsão nem quais os incentivos para a recuperação de habitações ou 
para a construção de novas. Além disso, o inciso IV aponta a importância do conjunto arquitetônico da zona.

No entanto, a legislação ${ }^{28}$ e o mapeamento das Zeis 3 foram fundamentais para futuros projetos destinados a mitigar o problema das populações encortiçadas, tanto do poder público - o Alegra Centro Habitação e o Programa de Atuação em Cortiços da CDHU - quanto das organizações populares - o projeto da ACC.

Figura 11: Zonas de Especial Interesse Social - Santos-SP.

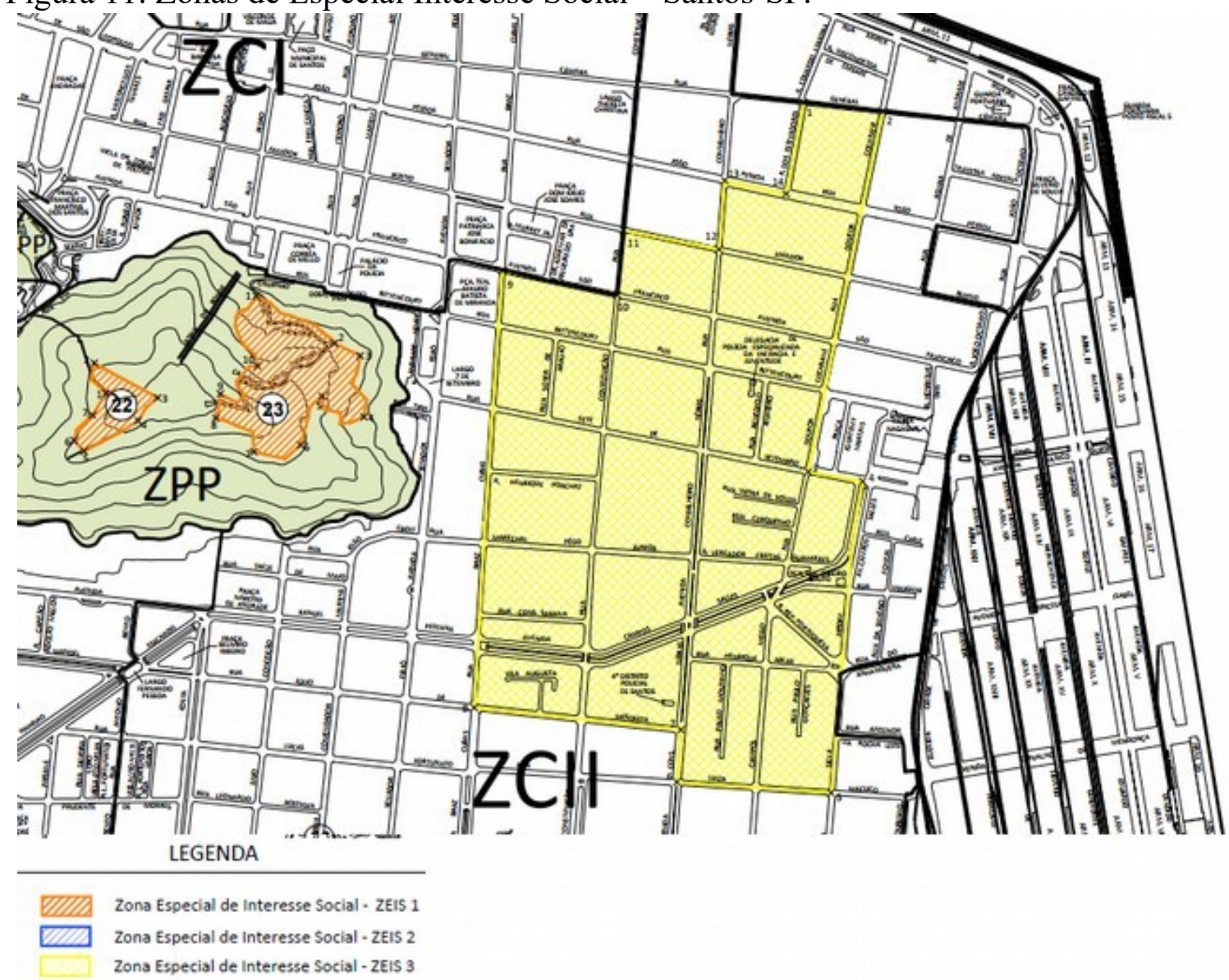

Fonte: Prefeitura de Santos.

28 Algumas modificações no texto legislativo sobre ZEIS no Plano Diretor de 2013, ainda que sua área permaneça a mesma desde 2008: “Art. 42. As ZEIS 3 de Interesse Social - ZEIS são determinadas porções de território com destinação específica e que atendem às normas próprias de uso e ocupação do solo, destinadas à regularização fundiária e urbanística, produção e manutenção de Habitação de Interesse Social - HIS e de Habitação de Mercado Popular - HMP, obedecendo àseguinte classificação: [...]

III - Zona Especial de Interesse Social 3 - ZEIS 3, que são áreas com concentração de edificações de uso residencial pluri-habitacional precário, nas quais serão desenvolvidos programas e projetos habitacionais destinados, prioritariamente, ao atendimento da população de baixa renda familiar moradora na respectiva ZEIS, conforme cadastro existente no órgão de planejamento ou de habitação do Município. [...] $\S 3^{\circ}$ As disposições citadas no inciso III deste artigo poderão ocorrer nos casos de melhoria de condições de habitabilidade em edificações de uso residencial pluri-habitacional precário e de remanejamento de moradores cadastrados para novas unidades habitacionais, preferencialmente na mesma ZEIS 3." (Prefeitura Municipal de Santos, Lei Complementar nº 821, de 27 de dezembro de 2013). 
De 1997 a 2000, na primeira gestão municipal de Beto Mansur (do então Partido Progressista Brasileiro, que passou a se denominar Partido Progressista em 2003), a legislação de Zeis se manteve, mas apenas por forte pressão popular. O Executivo propôs que a lei fosse revogada, mas a mobilização de segmentos populares contribuiu para que a Câmara Municipal mantivesse a Zeis no Plano Diretor de 1998 (SANTOS, 2008).

Este novo plano diretor estabeleceu os Corredores de Proteção Cultural (CPC): Zonas Centrais I e II e Zona Portuária, para facilitar a intervenção do poder público em imóveis de importante valor histórico.

Em 2001, com a reeleição de Beto Mansur (gestão finalizada em 2004), foi criada a Secretaria de Planejamento (Seplan) e, com ela, o Programa Alegra Centro começou a ser desenvolvido. Este programa foi responsável por delimitar áreas de proteção cultural (ampliando os antigos corredores de proteção cultural) e por enquadrar cada imóvel das áreas em um nível de proteção:

Art. $4^{\circ}-[\ldots]$

I - Nível de Proteção 1 (NP1) - Proteção total, atinge imóveis a serem preservados integralmente, toda a edificação, os seus elementos construtivos e decorativos, interna e externamente;

II - Nível de Proteção 2 (NP2) - Proteção parcial, atinge os imóveis a serem preservados parcialmente, incluindo apenas as fachadas, a volumetria e o telhado;

III - Nível de Proteção 3a (NP3a) - Livre opção de projeto, mantendo-se porém, o gabarito predominante dos imóveis NP1 e NP2 existentes na testada da quadra em que estiver inserido e quando da inexistência destes na mesma quadra, nas testadas das quadras subsequentes e alinhadas a esta.

IV - Nível de Proteção 3b (NP3b) - Livre opção de projeto para os edifícios, porém respeitando-se o gabarito máximo de 35 metros de altura contados a partir da calçada fronteiriça ao imóvel. [...]

V - Nível de Proteção 4 (NP4) - Livre opção de projeto, respeitados os índices urbanísticos da zona em que o imóvel se encontrar conforme a Lei Complementar $n^{\circ} 312 / 98$ e suas alterações (Prefeitura Municipal de Santos, Lei Complementar $\mathrm{n}^{\circ} 470$, de 5 de fevereiro de 2003).

Nos imóveis enquadrados como NP1 e NP2 é oferecida isenção do Imposto Predial e Territorial Urbano (IPTU) e do Imposto sobre Serviços de Qualquer Natureza (ISSQN) para a reforma e restauro, do Imposto de Transmissão de Bens Intervivos (ITBI) no caso de compra e venda do imóvel, e isenção da Taxa de Licença de Localização e Funcionamento (devendo ser renovada anualmente, por até 5 anos) aos proprietários que os restaurarem. Para a restauração, a Prefeitura disponibiliza um serviço de consultoria gratuita, realizada pela Seção Escritório Técnico Alegra Centro (Setac) ${ }^{29}$ da Seplan e também determina uma série de regras

29 Ressaltamos que quando foi criada, em 2003, a Setac contava com cinco funcionários, e em 2016 somente 
técnicas para a interferência nas fachadas. $\mathrm{O}$ projeto inclui ainda a previsão de embutir a fiação elétrica e os cabos de fibra ótica e de melhorar a iluminação e as calçadas (ALEGRA CENTRO, 2015). O projeto definiu sua área de abrangência de acordo com a área envoltória de bens já protegidos pelos órgãos de patrimônio - tentando assim, evitar conflitos maiores com o mercado imobiliário e o setor da construção civil -, mas muitos dos imóveis protegidos em algum nível pelo Alegra Centro não são tombados pelos órgãos de preservação do patrimônio municipal, estadual ou federal. Comparando as figuras 11 e 12, pode-se perceber que 10 quarteirões se sobrepõem como APC e como Zeis 3, especialmente perto do Mercado Municipal, ao longo da Rua Dr. Cochrane.

O centro de Santos mantém um patrimônio cultural tombado expressivo, com imóveis coloniais, como a Casa de Câmara e Cadeia e o Mosteiro São Bento, e de arquitetura eclética, como a Bolsa do Café (atual Museu do Café), a Casa da Frontaria Azulejada e o Teatro Coliseu. Apesar destes imóveis citados estarem em bom estado de conservação, esse não é o caso de todo o patrimônio arquitetônico protegido de Santos: muitos prédios estão em ruínas, como a antiga hospedaria dos imigrantes.

dois funcionários trabalhavam nessa repartição. 
Figura 12: Áreas de Proteção Cultural do Programa Alegra Centro.

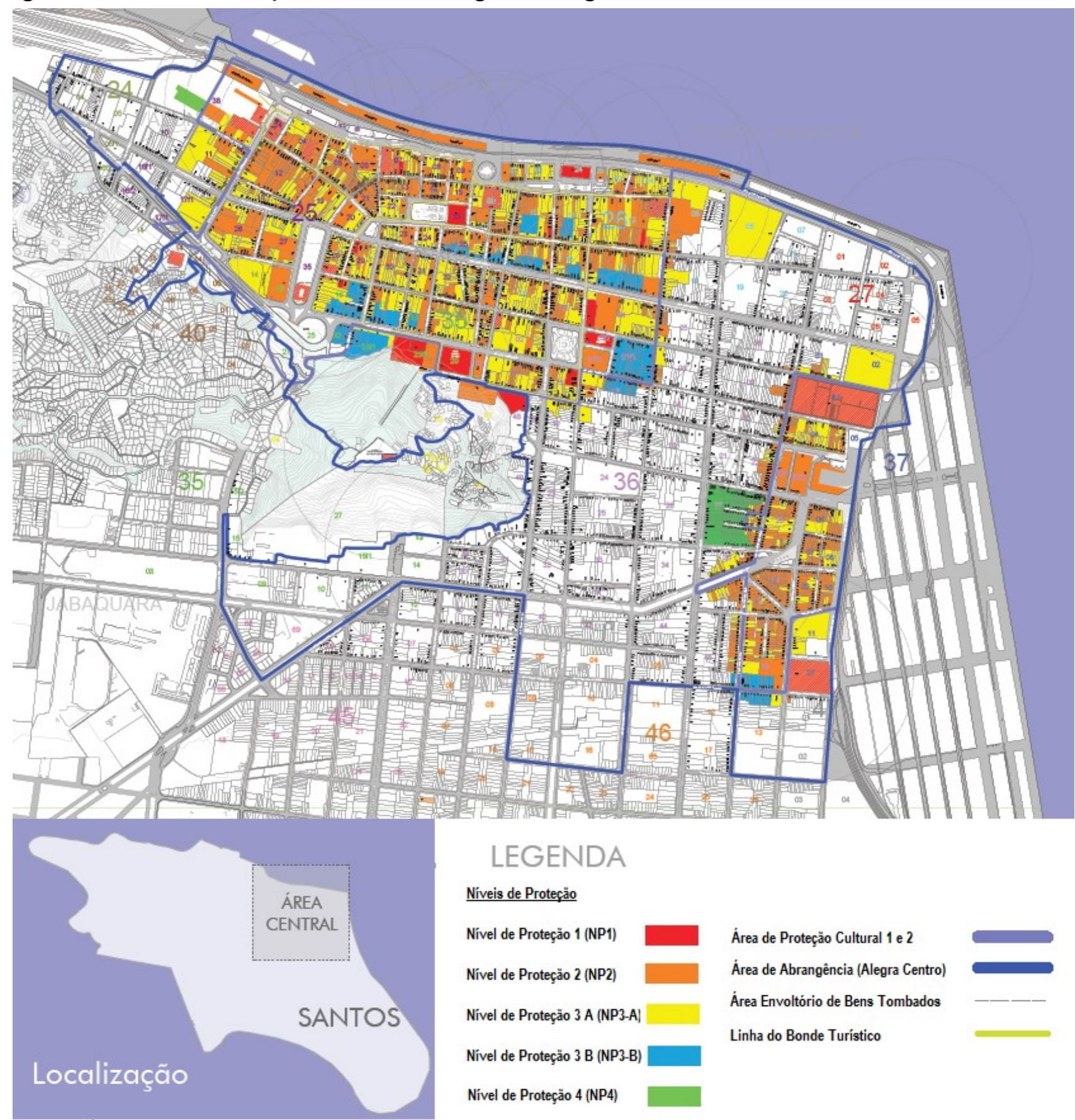

Fonte: Escritório Técnico do Alegra Centro. 
Figura 13: Bens tombados no município de Santos-SP

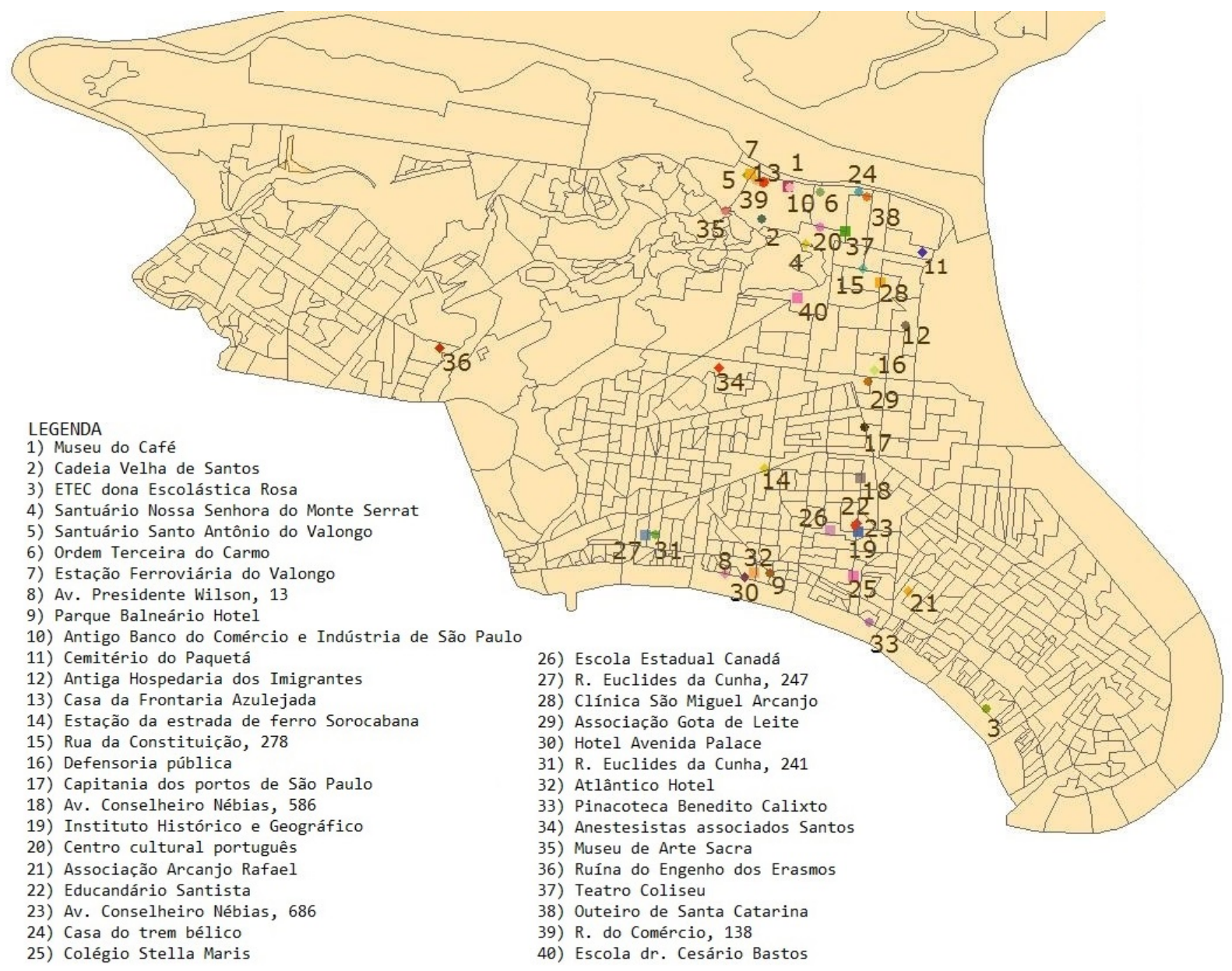

Fonte: Condepasa, elaboração: Bruna G. Eskinazi.

Somente em 2008, após pressão popular, foram incluídos na legislação itens relativos aos cortiços e à habitação popular:

Art. $4^{\circ} \mathrm{A}$ - III A provisão habitacional visando a atração de novas habitações e a solução para os cortiços visando a permanência e a inclusão social da população $[\ldots]$

Art. $9^{\circ}$ - II Incentivar o uso habitacional na Área de Proteção Cultural e na periferia dela (Prefeitura Municipal de Santos, Lei Complementar $n^{\circ} 640$, de 18 de novembro de 2008).

Um projeto de reforma urbanística que por mais de cinco anos ignora as 1.692 famílias moradoras de cortiços existentes na cidade (IBGE, 2010), em situações de insalubridade, instabilidade e desconforto, é um projeto que não está interessado nas necessidades básicas da população mais pobre, e sim no crescimento econômico e nas potencialidades turísticas do município. Frequentemente esse tipo de reforma não prevê equipamentos públicos, planos de habitação social, ou até mesmo a inserção da população moradora do centro no projeto. Seria possível, por exemplo, pensar em capacitação profissional para incluir a população dos 
bairros centrais na geração de empregos esperada pela reforma urbanística.

Outra característica importante desse tipo de planejamento é a ênfase em projetos de embelezamento e de "revitalização" de determinados espaços que tenham apelo comercial e turístico, como uma decadente zona portuária. Nada contra a recuperação de espaços desvalorizados e meio abandonados, nem contra a criação de "corredores culturais" com restaurantes, cinemas e teatros para serem desfrutados pela classe média e atraírem turistas; o problema é como isso tem sido proposto e feito (principalmente, com que custos), sendo que os pobres acabam de várias maneiras, sendo excluídos dos benefícios (SOUZA, 2004, p. 55).

A ideia principal do programa, inspirada em modelos de Recife e Salvador, era estimular atividades noturnas de entretenimento, tais como cafés, bares, boates e casas de show, objetivo que foi cumprido nestes 13 anos de programa, principalmente na rua XV de Novembro, onde se concentram tais empreendimentos. "A produção dos espaços de turismo e de lazer se realiza como consequência do mundo da mercadoria (...) produzem o espaço enquanto mercadoria de consumo 'em si', utilizando-se de suas características particulares" (CARLOS, 1999, p. 119).

Um dado significativo é o crescimento do número de empresas instaladas no centro: quase 4 mil foram abertas entre 2003 e 2011 nas áreas de proteção cultural.

[O centro antigo] sobrevive graças ao seu duplo papel: lugar de consumo e consumo do lugar. Assim os centros antigos entram mais completamente na troca e no valor de troca, não sem continuar valor de uso em razão dos espaços oferecidos às atividades específicas. Eles se tornam centros de consumo (LEFEBVRE, 1968, p. 21, tradução nossa). ${ }^{30}$

Assim pode ocorrer nos próximos anos o chamado processo de gentrificação, ou seja, o retorno das camadas da população com alto poder aquisitivo, que tinham abandonado o centro da cidade, acarretando uma menor valorização da terra no local, em comparação a outras regiões de Santos. Seria uma mudança muito bem recebida pelo mercado imobiliário.

O conceito de gentrificação foi cunhado por Ruth Glass em Londres, em 1964:

Um por um, muitos dos bairros da classe trabalhadora de Londres foram invadidos pelas classes médias - superiores e inferiores. Velhos sobrados e casas geminadas - com dois quartos em cima e dois em baixo - foram retomados pelo proprietário, quando seus contratos de aluguel expiraram, e tornaram-se residências elegantes e caras. Grandes casas vitorianas, rebaixadas em um período anterior ou recente - que eram usadas como casas de pensão ou habitações multifamiliares - voltaram a ser valorizadas... Uma vez que este processo de "gentrificação" começa em um distrito, ele continua rapidamente até que todos ou a maioria dos ocupantes originais da

30 "[Le centre ancien] survit grâce à ce double role: lieu de consommation et consommation du lieu. Ainsi les centres anciens entrent plus complètement dans l'échange et la valeur d'échange, non sans rester valeur d'usage em raison d'espaces offerts à des activités spécifiques. Ils deviennent centres de consommation" (LEFEBVRE, 1968, p. 21). 
classe trabalhadora sejam deslocados e todo o caráter social do distrito seja alterado (GLASS, R. 1964, p. vxiii apud SMITH, N., 1996, p. 31, tradução nossa). ${ }^{31}$

O conceito, que tem na sua raiz a palavra gentry, explicita o seu caráter de classe e é utilizado para explicar a mudança das classes sociais de determinados bairros. Em um período anterior à gentrificação, a ocupação de novos bairros cria uma elevação do valor da terra nos novos lugares e uma queda relativa do valor da terra nos bairros ao redor do centro urbano, causando o que Smith descreveu como rent-gap "entre a atual renda da terra capitalizada pelo uso presente (deteriorado) e a renda da terra potencial que poderia ser capitalizada pelo 'mais elevado e melhor' uso da terra" (2007, p. 21). Ou seja, a desvalorização do capital investido no ambiente construído pode ser utilizada em um futuro para criar oportunidades de reestruturação urbana e de ampliação da renda da terra. Essa estratégia, muito bem recebida pelo capital imobiliário, especialmente ligada a economia de serviços e a sede de empresas, ocorre junto ao processo de gentrificação: o fortalecimento da segregação socioespacial com o retorno das camadas mais abastadas para o centro revalorizado (renovado e "revitalizado", como se diz habitualmente) e a expulsão das famílias pobres que lá vivem.

A "apropriação da renda é a forma econômica na qual se realiza a propriedade da terra" (CARLOS, 2015, p. 93); nesse caso a renda da terra ${ }^{32}$ é expressa pelo aluguel que cada família paga por seu cômodo, e tem com a gentrificação a possibilidade de ser expandida com a mudança de público-alvo a se apropriar do centro. Concordamos com Martins (1981) quando afirma que a tendência do capital é subordinar todos os setores da produção e a terra pode se colocar como um obstáculo a seus objetivos. No caso dos centros urbanos, a própria moradia de trabalhadores de baixos rendimentos pode ser um entrave ao mercado imobiliário que quer "modernizar" e expandir a extração de renda de certos lugares da cidade que já contam com infraestrutura.

Por enquanto esse processo não se concretizou no centro de Santos, não houve um aumento de população residente no centro, muito menos de classes de rendimentos médios. Até mesmo

31 "One by one, many of the working-class quarters of London have been invaded by the middle classes upper and lower. Shabby, modest mews and cottages - two rooms up and two down - have been taken over, when their leases have expired, and have become elegant, expensive residences. Larger Victorian houses, downgraded in an earlier or recent period - which were used as lodging houses or were otherwise in multiple occupation - have been upgraded once again... Once this process of 'gentrification' starts in a district it goes on rapidly until all or most of the original working-class occupiers are displaced and the whole social character of the district is changed (GLASS, R. 1964: vxiii apud SMITH, N., 1996, p. 31).

32 Há uma diferença entre o juro das edificações (do capital fixo incorporado ao solo) e a renda da terra. O primeiro normalmente é pago de forma agregada com o segundo, e permite a sua valorização (CARLOS, 2015). 
os empreendimentos imobiliários para escritórios que foram construídos nos últimos anos no entorno das APCs não foram totalmente ocupados. Mas é um processo em andamento, que apresenta características em comum com outros processos de gentrificação no mundo, que levam de duas a quatro décadas para se concretizarem. O próprio Smith (1996) coloca que estes processos, por mais que ocorram em cidades em todas as partes do globo, possuem sempre elementos particulares: a conformação anterior das cidades, as regulações locais do uso do solo urbano, o funcionamento do mercado imobiliário local (por mais que este esteja cada vez mais sendo financiado por fundos internacionais).

Nos estudos de Smith (1996; 2007), centrados nos Estados Unidos, onde o processo de suburbanização no pós-guerra foi predominante, observou-se um nível muito inferior nos valores dos aluguéis nos bairros localizados entre o centro e os subúrbios. No entanto, no Brasil, por mais que em muitas cidades exista a autossegregação das classes de rendimentos médios em condomínios fechados, este processo não é o predominante. A tendência é que grande parte dessa população resida em bairros mais próximos ao centro; segundo Villaça (2001), isso tende a ocorrer em um quadrante do círculo em torno do centro, onde a infraestrutura urbana é melhor - ainda que esses padrões de moradia venham se modificando nas últimas duas décadas. Ou, como acontece em muitas cidades litorâneas, na orla da praia e em bairros bem servidos de transporte e boas vias de comunicação com o centro.

Desde a década de 1950, com a expansão imobiliária na orla, tanto residencial como para veraneio, subcentros se formaram em Santos, em especial no bairro Gonzaga. Não que o centro deixe de concentrar comércio, serviços e empregos, mas passa a ser menos frequentado pelas classes de rendimentos médios e altos e pelos turistas, que passam a utilizar cada vez mais os subcentros e os shopping centers.

É importante frisar que "foi o abandono que fez com que os edifícios se deteriorassem. Não foi a deterioração que provocou o abandono" (VILLAÇA, 2001, p. 282). Smith (1996) explica este padrão de desinversão de capitais em determinadas localidades da cidade. $\mathrm{O}$ capital investido no espaço construído é de longo retorno, e a análise da relação entre valor do solo e dos edifícios é explicada a partir da desagregação em quatro categorias: valor da construção, preço de venda, renda capitalizada do solo e renda potencial do solo. O valor da construção está relacionado a sua taxa de desvalorização pelo uso ao longo do tempo, e o preço inclui o valor da construção e a renda capitalizada do solo, além de estar relacionado às condições de oferta e demanda. Quanto maior a desinversão de capitais em um determinado 
local, maior se torna a diferença entre a renda capitalizada do solo e a renda potencial do solo. A desinversão de capitais acontece em um extenso período de tempo e é comum que a manutenção dos edifícios seja menor quando estes são alugados.

A subdivisão das estruturas para produzir mais unidades de aluguel é comum nesta fase. Ao subdividir, o proprietário espera intensificar o uso do edifício (e sua rentabilidade) em seus últimos anos. Mas, eventualmente, os proprietários desinvestirão totalmente, recusando-se a fazer reparos e pagando apenas os custos necessários - e, muitas vezes, apenas esporadicamente - para que o prédio gere renda (SMITH, 1996, p. 64, tradução nossa). ${ }^{33}$

Em Santos é bastante comum que os cortiços não sejam administrados por seus proprietários, mas por um locatário que subloca as unidades e é conhecido pelos moradores como "o dono da chave". Este locatário raramente realiza reformas nas casas, com exceção de construções de quartos nos quintais para ampliar o número de moradores.

Dessa forma, os padrões desiguais de inversão e desinversão de capitais na cidade criam ao longo do tempo oportunidades para o mercado imobiliário reinvestir capitais, especialmente em momentos que combinam incentivos do Estado e uma queda na taxa de lucro em outros setores da economia. "O sucessivo desenvolvimento, subdesenvolvimento e redesenvolvimento de áreas específicas, conforme o capital salta de um lugar para outro, e enfim retorna, criando e destruindo suas próprias oportunidades de desenvolvimento" (SMITH, 1996, p. 84, tradução nossa). ${ }^{34}$

Este processo ocorre nas escalas globais e regionais, a gentrificação é a expressão do desenvolvimento desigual na escala urbana. Em que o próprio desinvestimento em determinadas áreas da cidade cria, no futuro, oportunidades de maior rentabilidade para o capital imobiliário.

“A valorização do capital refere-se mais ao conjunto dos lugares da cidade, do que à inversão de capital numa determinada parcela da cidade - o terreno em si - além de depender quase exclusivamente da força produtiva social do que das condições naturais" (CARLOS, 2015, p. 100). Por esse padrão de valorização, que não pode ser isolado nos terrenos da cidade, é que os processos de gentrificação se realizam na escala de bairros, com um conjunto de

33 Subdivision of structures to yield more rental units is common at this stage. By subdividing, the landlord hopes to intensify the building's use (and profitability) in its last few years. But eventually landlords will disinvest totally, refusing to make repairs and paying only the necessary costs - and then often only sporadically - for the building to yield rent (SMITH, 1996, p. 64).

34 "The successive development, underdevelopment and redevelopment of given areas as capital jumps from one place to another, then back again, both creating and destroying its own opportunities for development" (SMITH, 1996, p. 84). 
promotores imobiliários e com o apoio e regulação do Estado, para garantir o processo de valorização na área determinada.

Bidou-Zachariasen aponta que "a gentrificação não concerne, segundo os que a definiram, à simples revitalização de antigos bairros da elite, mas sobretudo, à mudança funcional dos antigos bairros que eram industriais, ou operários, e sua transformação sociológica" (2006, p. 28). Além da reabilitação residencial, a gentrificação

agora oferece um tipo de espaço urbano que integra ao mesmo tempo
trabalho, residência e lazer. Ela representa uma conquista classista da cidade.
Ela produz também o espaço urbano falsamente democratizado, passível de
ser "consumido" parcialmente por outras camadas sociais (BIDOU-
ZACHARIASEN, 2006, p. 34). Smith (1996) identificou três ciclos do processo: o primeiro, entre as décadas de 1950 e 1960, era espontâneo, de famílias que compravam e reformavam casas (o processo observado por Glass em Londres), e pode ser identificado em outros países europeus e nos Estados Unidos. No segundo ciclo, dos anos 1970 e 1980, o processo se intensifica, tanto na área que abrange quanto no volume de investimentos. No terceiro ciclo, a partir de 1994, a expansão do processo em Nova York, onde o autor baseia a maior parte de seus estudos, é sem precedentes, atingindo bairros bastante periféricos e até mesmo municípios da região metropolitana. Neste último ciclo, o processo atinge países subdesenvolvidos e apresenta "o novo papel do Estado; a penetração do capital financeiro; a dispersão geográfica; e a generalização da gentrificação setorial” (SMITH, 1996, p. 75, tradução nossa).

$\mathrm{O}$ autor define a gentrificação setorial como um grande aumento no financiamento privado das iniciativas de reformas e mudanças de usos de determinados bairros centrais. Nesta última fase, que atinge as cidades brasileiras, temos uma parceria entre os poderes locais, financiadores privados nacionais e internacionais e promotores imobiliários grandes e médios. Alvarez descreve o movimento de desvalorização-revalorização na cidade de São Paulo e os seus impactos sociais:

[...] é possível dimensionar a importância da produção do espaço, que se converte em um setor econômico de suma importância à reprodução capitalista, como amortecedor da crise de acumulação e, ao mesmo tempo, como produtor de um novo urbano, cujo sentido hegemônico é o da viabilização da reprodução do valor e/ou simplesmente da renda - se levarmos em consideração a relação intrínseca entre a produção do espaço e a financeirização -, destituindo, cada vez mais, as cidades de seu conteúdo histórico, suas referências e espaços públicos de sociabilidade para elevar ao sentido mais profundo o próprio espaço como mercadoria. Mas, diferentemente das outras mercadorias, a produção do espaço diz respeito à 
produção das condições de reprodução da vida, o que recoloca a dimensão do uso e da apropriação, aprofundando as lutas pelo espaço. Nesse contexto, ganha ainda maior importância o papel do Estado, seja para regulamentar as alianças entre os setores fundiário, imobiliário e financeiro, seja na definição de projetos urbanísticos de renovação/reestruturação urbana, ou ainda no uso do poder da violência para definir o lugar que cabe a cada um na cidade, como ocorre nos processos violentos de reintegração de posse em terrenos ou edifícios ocupados (ALVAREZ, 2015, p. 71).

Para Carlos (2015), o acirramento dos conflitos entre o valor de uso e o valor de troca das parcelas do espaço urbano explicitam, primeiramente, a forma como se realizou a ocupação do espaço, baseado na propriedade privada do solo e, portanto, em um processo de fragmentação e segregação; em segundo lugar, a atração de capitais de outros setores da economia para a reprodução do espaço, que é condição da reprodução ampliada do capital. Dessa forma o valor de uso é subjugado pelo valor de troca e, consequentemente, o espaço como condição da realização da vida é subjugado pelo espaço como condição da acumulação.

Hiernaux-Nicolas (2006) faz um estudo na Cidade do México que apresenta algumas semelhanças com o caso de Santos. Desde a década de 1980, quando o centro da capital mexicana foi declarado Patrimônio da Humanidade pela Unesco, projetos de restauro e instalação de restaurantes e lojas para classes de rendimentos mais altos têm pressionado as "vecindades" - nome dado aos cortiços existentes nas antigas mansões do final do século XIX. Ainda que a quantidade de famílias das classes de rendimentos mais elevados voltando a morar no centro seja reduzida, estas já voltaram a frequentar esses bairros à noite e nos fins de semana. O autor avalia que "não se trata, sem nenhuma dúvida, de uma tendência sem volta, porque é possível que os revezes econômicos ou a força dos setores populares ponham freio a esta retomada. Mas ela também pode ter a chance de se impor como modelo dominante na Cidade do México" (HIERNAUX-NICOLAS, 2006, p. 259).

Para Patrice Melé, que também estuda estes processos nas cidades mexicanas,

a atribuição de um valor histórico às "vecindades" tem vários impactos contraditórios. Para muitos, a referência a uma grandeza passada, dos palácios e mansões particulares, leva a perceber os usos populares como pressões incompatíveis com a qualidade do patrimônio. Em algumas cidades, as autoridades locais reivindicam abertamente a restituição dos usos tradicionais das casas históricas ao uso de mansão particular (MELÉ, 2006, p. 207).

O projeto de reabilitação de imóveis de interesse histórico em Santos, o Alegra Centro, não colocou como proposta inicial (em 2003) reabilitações residenciais - na primeira versão da legislação a questão habitacional nem ao menos estava pautada. A centralidade do programa é a preservação das fachadas e o estímulo à instalação de comércio de varejo e serviços de 
qualquer natureza.

Está inspirado nos projetos de "revitalização" dos centros históricos de Salvador e Recife, em que se estimula a instalação de bares, cafés e restaurantes, e os governos locais patrocinam atividades culturais, como apresentações musicais, para atrair turistas e consumidores locais das classes de rendimentos médios. Ambos projetos, que serão apresentados com mais detalhes no capítulo 3, não previam a manutenção da população residente ou novos empreendimentos habitacionais e acarretaram a expulsão da maioria dos moradores para outros bairros.

Decorrente da pressão da população dos bairros centrais, descontente com o projeto Alegra Centro, em 2005 o artigo 9 - inciso II foi acrescentado: "Incentivar o uso habitacional na Área de Proteção Cultural e na periferia dela" (Prefeitura Municipal de Santos, Lei Complementar $\mathrm{n}^{\circ}$ 526, de 17 de março de 2005). No entanto, na lei complementar de 2005 não há nenhuma menção à forma de concretizar esse incentivo. Em 2008, a Lei Complementar 640 incluiu o artigo 4A, cujo inciso III aponta uma das estratégias do programa: “A provisão habitacional visando atração de novas habitações e a solução para os cortiços, visando a permanência e a inclusão social da população, na área de abrangência descrita no artigo $3^{\circ}$ desta lei, conforme dispuser lei específica" (Prefeitura Municipal de Santos, Lei Complementar nº 640, de 18 de novembro de 2018). Somente em 2010 a Prefeitura organizou um programa voltado para a questão habitacional, como será visto adiante.

O Alegra Centro até 2012 investiu R\$ 173,29 milhões ${ }^{35}$ por meio de isenções fiscais para 490 obras de restauro de imóveis, e realizou parcerias para obras de restauração de alguns edifícios. Captou recursos pela Lei Rouanet para a reforma do Teatro Guarany (desapropriado pela Prefeitura em 2003) e da Casa do Trem Bélico (R\$ 1,5 milhão ${ }^{36}$ em 2009), obteve financiamento do BNDES para a reforma do Casarão do Valongo, para a instalação do Museu Pelé (R\$ 50 milhões ${ }^{37}$ em 2014), e promoveu a reforma da Estação Ferroviária do Valongo

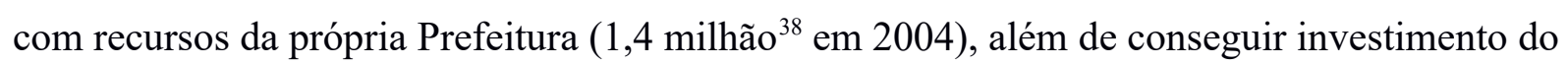
governo do Estado de São Paulo para a reforma de um antigo armazém para instalação do

35 US\$ 92.381.921,41. Valor convertido segundo taxa de câmbio de 01 jan. 2012. (R\$ 242.906.016,98 em março de 2018).

36 US\$ 641.848,50. Valor convertido segundo taxa de câmbio de 01 jan. 2009. (R $\$ 2.445 .676,20$ em março de 2018).

37 US\$ 21.343.805,00. Valor convertido segundo taxa de câmbio de 01 jan. 2014. (R\$ 60.132.130,00 em março de 2018).

38 US\$ 484.563,24. Valor convertido segundo taxa de câmbio de 01 jan 2004. (R\$ 2.954.044,80 em março de 2018). 
Poupatempo (R\$ 56,2 milhões ${ }^{39}$ em 2009) e a reforma do Teatro Coliseu (R\$ 16 milhões ${ }^{40}$ em 2004).

Frequentemente, os processos de gentrificação se dão com base em projetos culturais, de recuperação do patrimônio histórico. Otília Arantes (2000, p. 33) demonstra como o processo de gentrificação ocorre mundialmente, ${ }^{41}$ permeado pela comercialização da cultura:

À medida que a cultura passava a ser o principal negócio das cidades em vias de gentrificação, ficava cada vez mais evidente para os agentes envolvidos na operação que era ela, a cultura, um dos mais poderosos meios de controle urbano no atual momento de reestruturação da dominação mundial.

Trata-se da apropriação da cultura para negociar espaços urbanos de interesse para a reprodução do capital. O mundial se realiza no local, e estes processos se dão com especificidades nos diferentes contextos, é importante frisar que no Brasil esta apropriação da cultura não ocorre como nos países centrais.

Segundo Harvey $(2005,2014)$, o capital frequentemente cria rendas de monopólio, formas de controlar individualmente determinada mercadoria, ou até mesmo tornar uma mercadoria única, irreplicável. Esse processo também se dá com os lugares, muitas vezes utilizando o discurso da cultura. $\mathrm{O}$ autor afirma que

há lutas contínuas acerca da definição dos poderes de monopólio que poderiam ser concedidas ao lugar e às localidades, e que a ideia de "cultura" está cada vez mais ligada às tentativas de reafirmar esses poderes de monopólio, exatamente porque as afirmações de singularidade e autenticidade podem ser mais bem articuladas como reivindicações distintas e irreproduzíveis (HARVEY, 2014, p. 182).

É nesse sentido que os projetos de "revitalização" urbana frequentemente operam: por meio da cultura, com sua esfera de unicidade e autenticidade, que impulsiona o city marketing. Os projetos de gentrificação, especialmente quando promovidos pelas esferas estatais, não ocorrem sem toda uma linguagem para vendê-los como algo positivo, renouvellement no francês, regeneration no inglês, no Brasil o termo mais utilizado é "revitalização", como se nesses espaços sujeitos a reformas e mudanças de uso não houvesse anteriormente vida, como bem coloca Smith: "A classe trabalhadora urbana é considerada como menos que social,

39 US\$ 24.047.923,80. Valor convertido segundo taxa de câmbio de 01 jan. 2009. (R\$ 91.723.058,98 em março de 2018).

40 US\$ 5.537.865,60 Valor convertido segundo taxa de câmbio de 01 jan 2004. (R \$ 33.760.512,00 em março de 2018).

41 Fernanda Sanchez (2003) demonstra, com o caso de Curitiba-PR, como os espaços das relações de produção capitalista são incorporados ao novo planejamento urbano, podendo ser modificados para ampliar o consumo da cidade por obras de infraestrutura, otimização dos fluxos, modernização tecnológica, operações imobiliárias e por operações vinculadas ao turismo também no Brasil. 
como uma parte do ambiente físico" (1996, p.XVI) ${ }^{42}$

A reforma urbanística de Saturnino de Brito também fez parte do simbolismo criado para valorizar a imagem da cidade, para impulsionar o city marketing. Como o detalhe das muretas dos canais de água pluvial que se transformaram em símbolo da cidade, virando até suporte para um projeto artístico da Secretaria de Turismo de Santos, com um concurso de pintura.

Figura 14: Detalhe das muretas pintadas, em concurso artístico da Secretaria de Cultura.

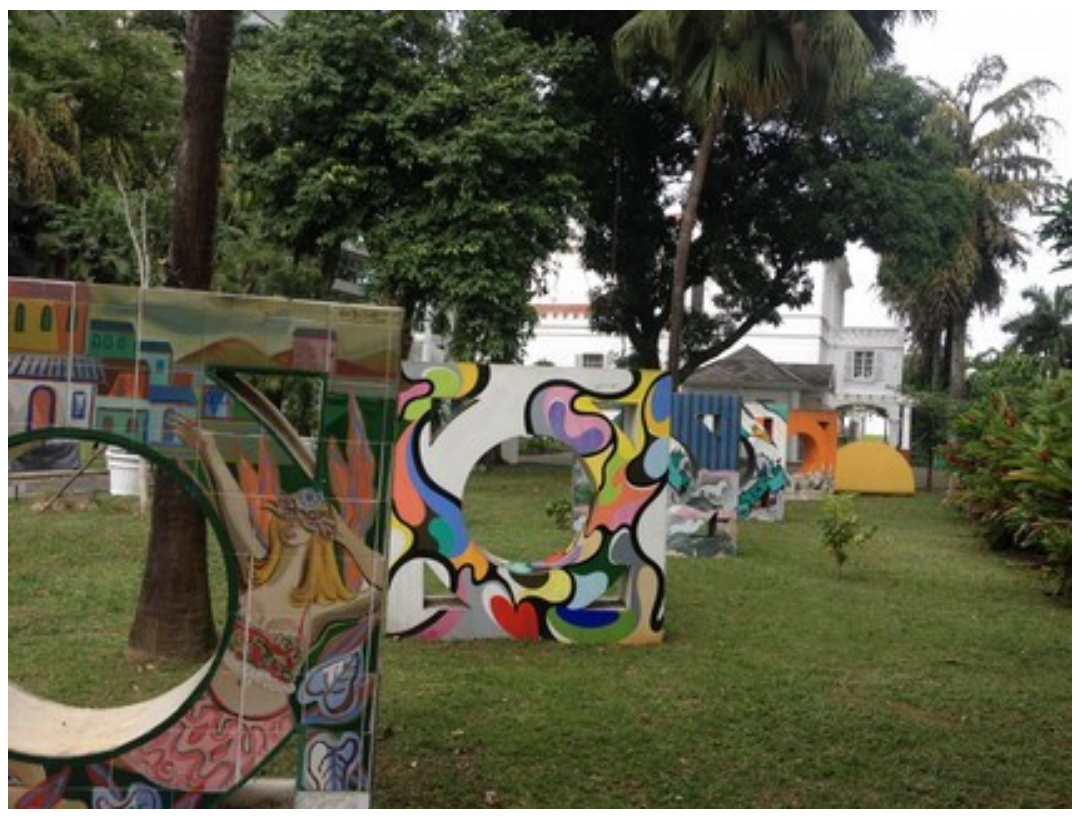

Fonte: Bruna G. Eskinazi - maio de 2017.

Figura 15: Muretas na Ponta da Praia - Santos-SP.

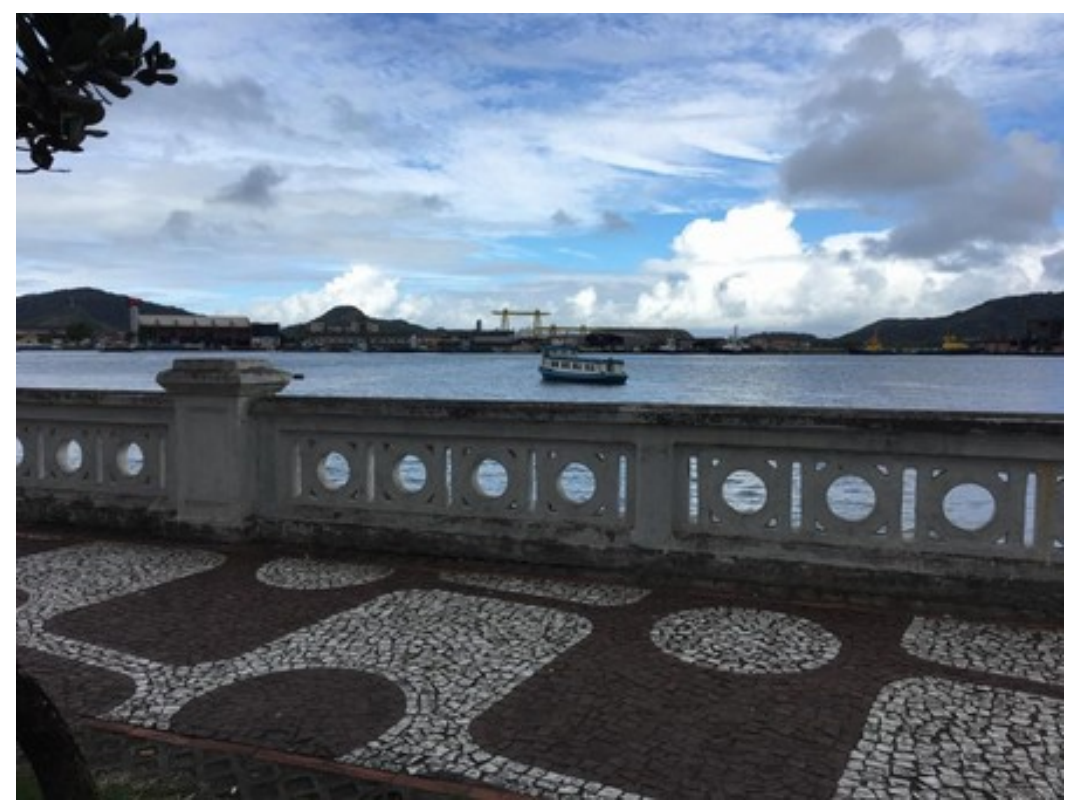

Fonte: Gabriela Everett - outubro de 2016.

42 "The urban working class is seen as less than social, a part of the physical environment." (1996, p. XVI). 
Esses projetos de "revitalização" urbana não consideram o valor de uso desses espaços para as pessoas que lá vivem: "O valor de troca ganha uma amplitude expandida, o que pode ser constatado pela produção dos simulacros espaciais como decorrência de revitalizações urbanas ou por meio das exigências do desenvolvimento do turismo" (CARLOS, 2015, p. 67$68)$.

A transferência de capitais de outros setores econômicos para o setor da construção civil transforma a cidade no grande negócio da acumulação capitalista atual. Conforme afirma Santos, esta transferência

ocorre com um alto teor de violência, separando na prática aquilo que aparece separado no conceito, a saber: o espaço e seu conteúdo social. A remoção de moradias, de elementos da história e da memória, das marcas do tempo e de uma sociabilidade outra que não a mais ajustada aos propósitos da acumulação atual aparece como "revitalização", ordenamento ou até mesmo como organização do espaço, quando, de fato, representam a aniquilação de espaços pretéritos, revelando a força destrutiva das estratégias de acumulação que têm na reprodução do espaço urbano seu material primordial e objeto essencial (SANTOS, 2015, p. 34).

Apesar do grande número de reformas nas Áreas de Proteção Cultural houve um aumento, dos imóveis desocupados e em ruínas, como demonstra o gráfico 1:

Gráfico 1: Imóveis desocupados e em ruínas e terrenos vazios nas APCsFonte: Material cedido

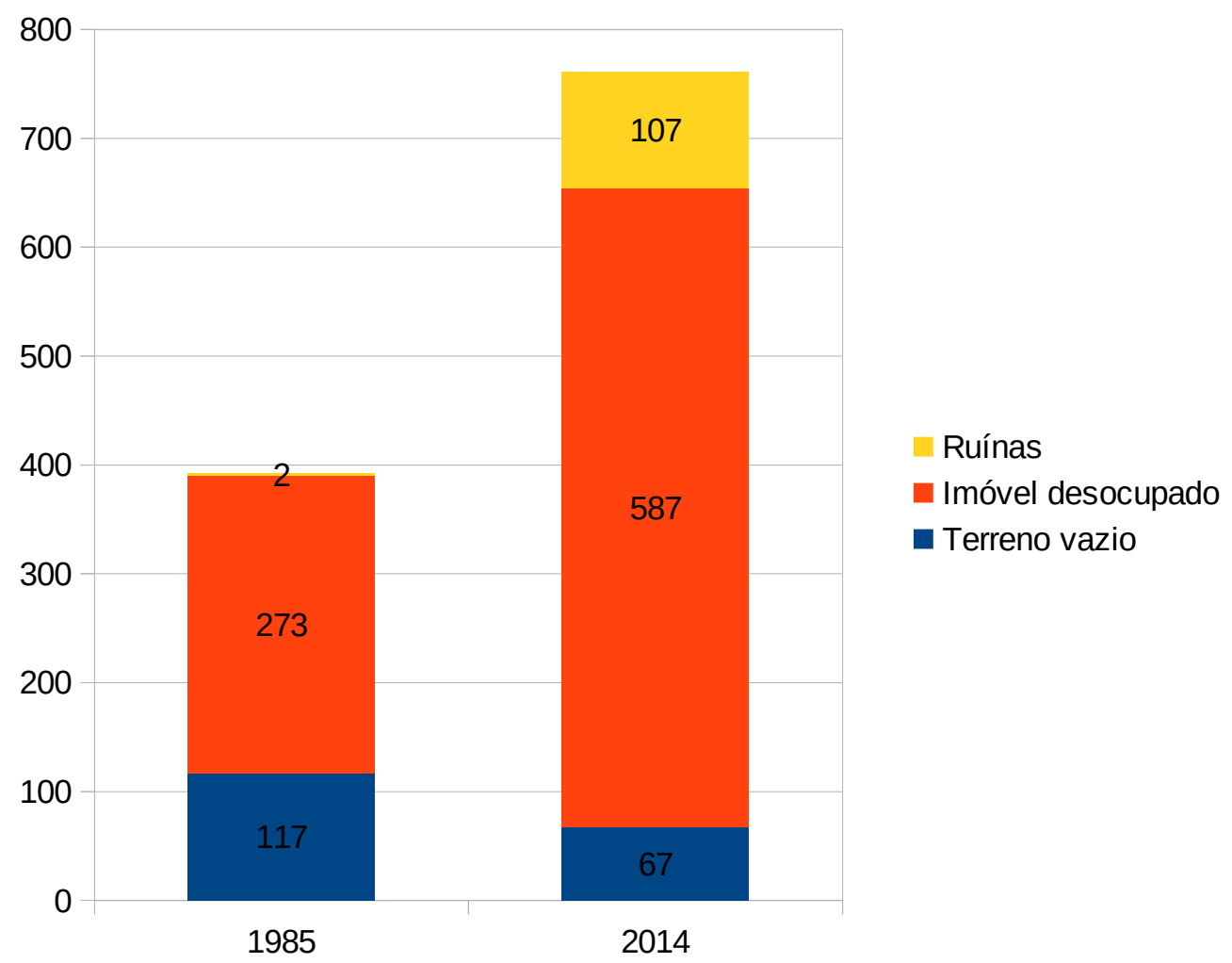

pelo Escritório Técnico do Alegra Centro (adaptado). 
Outro fato digno de nota é a situação dos imóveis NP3B do Alegra Centro: essa categoria tem livre opção de projeto, ou seja, pode ser construído qualquer imóvel que esteja na faixa de gabarito até 35 metros. No entanto, dentro das APCs, nenhum imóvel NP3B foi modificado. Alguns são estacionamentos ou armazéns sem valor arquitetônico significativo. São cerca de 120 imóveis somente na APC 1.

Cabe também apontar a grande diferença existente entre os usos da APC 1 e da APC 2. A APC 2 possui apenas dois imóveis tombados pelo Condepasa, e, portanto, no nível de proteção 1: o Cemitério do Paquetá e o Mercado Municipal. O Mercado tem menos bancas do que há algumas décadas, mas no seu entorno existem diversos armazéns de alimentos perecíveis e não perecíveis que abastecem os supermercados e quitandas de Santos e de outros municípios da Baixada Santista. Dentro do Mercado ainda há uma área destinada a cursos, "Vila Criativa", instalada pela Prefeitura em 2016. ${ }^{43}$ Alguns armazéns, como o "Prabar" e o "Transcontainer", eram anteriormente cortiços que foram demolidos. A creche municipal Irmã Maria Dolores foi instalada em 2009 em um imóvel que era antes um cortiço. A APC2 tem também em sua área algumas oficinas mecânicas, imóveis em ruínas, bares, uma floricultura (em frente ao cemitério) e o Moinho Paulista. Por ser vizinha ao porto e por causa dos armazéns, a área tem intenso fluxo de caminhões.

Já a APC 1 abrange o centro da cidade: tem 30 imóveis classificados como NP1, e vários destes são tombados. É a parte mais antiga da cidade e concentra muitos comércios e serviços (com destaque para a Rua João Pessoa, que foi alargada na década de 1970), vários edifícios do poder público municipal, estadual e federal, terminal rodoviário e terminal de ônibus urbano.

\subsection{Alegra Centro Habitação}

Em 2008, após pressões da população moradora do centro, que estava bastante descontente com tantos recursos destinados à reforma de fachadas, sem trazer melhorias para a questão da moradia, a Prefeitura criou o projeto Alegra Centro Habitação que surgiu baseado na lei de Zeis 3, de 1992, que identificou as áreas de concentração de cortiços nos bairros centrais deteriorados. A Zeis 3 se sobrepõe parcialmente à APC 2. Essas áreas encortiçadas receberam

43 São oferecidos cursos profissionalizantes de marcenaria, artesanato com fibra de bananeira, bordado, costura, pintura em tecido, etc. Os cursos são exclusivos para pessoas atendidas pela Secretaria de Assistência Social e está prevista a construção de um espaço anexo para sediar cursos de cabeleireiro, manicure, barbeiro e maquiagem. 
então nova proposta de reabilitação. Os imóveis deveriam ser adaptados para se adequarem aos parâmetros mínimos de habitabilidade previstos pela nova Lei de Habitação. Com ventilação, instalação elétrica e iluminação adequadas e pé direito mínimo de 2,5 metros.

A legislação diferencia três tipos de imóvel residencial pluri-habitacional reabilitado: $1^{\text {o }}$ : unidades de até $20 \mathrm{~m}^{2}$, tendo como parâmetro mínimo $5 \mathrm{~m}^{2}$ por pessoa mais o sanitário, dispõem de área de serviço coletiva e terão como finalidade locação. $2^{\circ}$ : unidades de 20 a 40 $\mathrm{m}^{2}$ que poderão ser alugadas ou vendidas, e devem conter ao menos quarto, sala, cozinha e banheiro. $3^{\circ}$ : unidades entre 40 e $60 \mathrm{~m}^{2}$ (sendo que moradias com mais de $60 \mathrm{~m}^{2}$ não se enquadram, pela lei, no padrão de moradia de interesse social), com área de serviço interna e banheiro mínimo de $2 \mathrm{~m}^{2}$, também podem ser alugadas ou vendidas.

O projeto tinha os seguintes objetivos:

I - Promover a melhoria da qualidade de vida da comunidade por meio de:

a) viabilização da requalificação das condições de moradia dos imóveis de uso residencial precário da Região Central Histórica de Santos;

b) incentivo à reabilitação dos imóveis de uso residencial pluri-habitacional subnormal aos parâmetros mínimos de habitabilidade contidos nesta lei complementar, a partir de um plano de ação que vise à permanência da população local e melhoria de sua qualidade de vida;

c) incentivo à implementação de novas unidades para imóveis com uso residencial uni-habitacional e residencial pluri-habitacional;

d) promoção da preservação e recuperação do meio urbano e das relações de cidadania;

e) incentivo à geração de trabalho e renda priorizando ao recrutamento de mão de obra local.

II - fomentar o fortalecimento do comércio e a prestação de serviços de extensão natural das residências;

III - propor a ampliação e a melhoria de rede de serviços públicos na área de abrangência do programa, especialmente os de caráter social - educação, saúde, cultura, esportes, transportes públicos e assistência social;

(Material cedido pelo projeto Alegra Centro Habitação - Secretaria de Planejamento - Prefeitura de Santos).

O processo de reabilitação dos cortiços proposto pelo Alegra Centro Habitação está esquematizado no organograma abaixo, com as fases de orientação técnica, elaboração do projeto e fiscalização realizadas pelo Escritório Técnico da Prefeitura. 


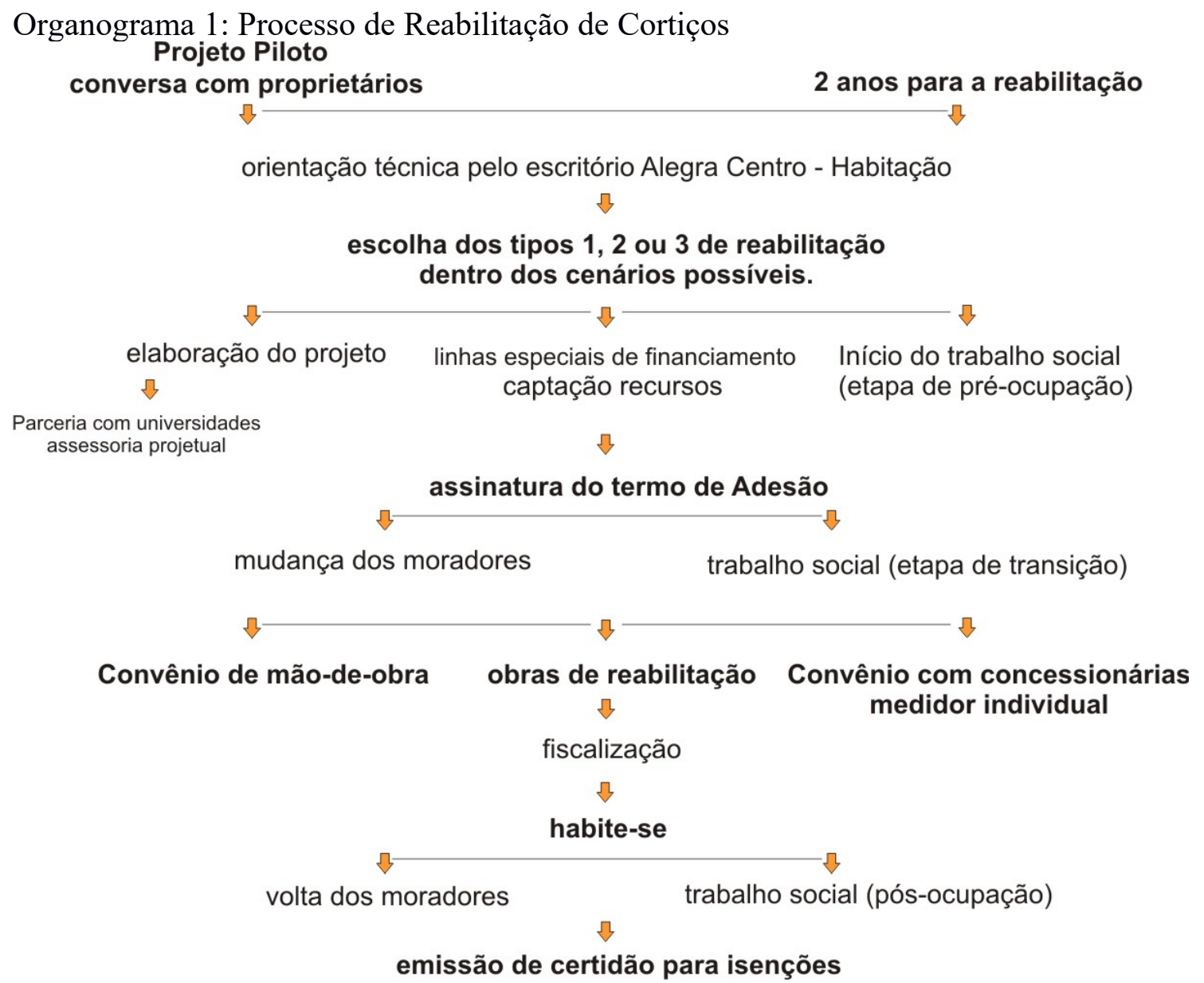

Fonte: Material cedido pelo Escritório Técnico do Alegra Centro Habitação.

Os donos e locatários desses imóveis contam com o suporte do Escritório Técnico, assim como no projeto Alegra Centro, mas poderão sofrer sanções, caso não cumpram o que foi estabelecido, cabendo ao poder público fiscalizar esses imóveis:

Empresários que construírem residências na região e donos de imóveis que recuperarem as moradias receberão até oito incentivos fiscais, com isenção parcial ou total de impostos (ITBI, ISS, IPTU, entre outros) e de taxas municipais. Os proprietários de moradias precárias que não cumprirem as exigências estarão sujeitos à multa de $\mathrm{R} \$ 2$ mil até $\mathrm{R} \$ 8$ mil, ${ }^{44}$ que pode chegar até $50 \%$ do valor venal do imóvel para quem não aderir ao programa (http://www.portal.santos.sp.gov.br/alegra, 2013).

No entanto, as ações desse programa não foram muito bem-sucedidas. De acordo com a Seção Escritório Técnico Alegra Centro, alguns proprietários, após serem pressionados para reformar seus imóveis, optaram por desocupá-los, resultando no despejo de várias famílias. Como essa não era a intenção da Prefeitura, o programa foi interrompido. Atualmente não há um espaço nem técnicos responsáveis pelo projeto dentro da Prefeitura. A legislação do

44 De $\mathrm{R} \$ 4.786,42$ a R $\$ 19.145,68$, em valores corrigidos para março de 2018. 
Alegra Centro e do Alegra Centro Habitação estão sendo revistas conjuntamente. Os técnicos estão juntando dados sobre os programas e estão sendo realizadas audiências públicas para a revisão da lei. Infelizmente, as expectativas deste programa não foram cumpridas. Ainda que seja insuficiente para resolver o problema do deficit habitacional, garantir padrões de salubridade e de segurança nessas moradias é muitíssimo importante.

O então secretário de Desenvolvimento Urbano, Nélson Gonçalves de Lima Júnior, fez uma declaração sobre as intenções da Prefeitura em fazer modificações no Alegra Centro:

Queremos fazer uma revisão geral do Alegra Centro. Achamos que ele tem um potencial muito maior do que foi desenvolvido até o momento. E o Alegra Centro Habitação não aconteceu. Por isso, é necessária uma revisão absolutamente completa, para que os empresários da construção civil possam olhar o centro com mais atenção. É preciso que haja entusiasmo do empresariado para que se desenvolva a habitação no centro (PREFEITURA MUNICIPAL DE SANTOS, 2013).

Desde 2013 se discute na Prefeitura a reformulação das Leis do Alegra Centro e do Alegra Centro Habitação, articulando-as em uma legislação única, definida após a revisão da Lei de Uso e Ocupação do Solo. Essas mudanças ainda não foram realizadas, mas a Câmara Municipal realizou em novembro de 2017 consultas públicas para discutir a implementação de Zonas Especiais de Renovação Urbana (Zerus) no Paquetá e no Valongo, adjacentes às APCs. O secretário adjunto de Desenvolvimento Urbano, Glaucus Farinello, explicou as metas da Prefeitura:

Todo o trabalho desenvolvido pelos técnicos foi com o objetivo de recuperar áreas degradadas entre esses dois polos. Flexibilizando a legislação urbanística, queremos atrair o mercado imobiliário. A construção de novos empreendimentos habitacionais, e a segunda fase do VLT, somada à requalificação dessa área vai trazer mais moradores para o Centro (PREFEITURA MUNICIPAL DE SANTOS, 2017).

Uma das possíveis flexibilizações da legislação é permitir o adicional de coeficiente de aproveitamento sem a exigência de outorga onerosa; outra é estabelecer parcerias públicoprivadas (PPPs) para a produção de moradias. Para o ex-secretário Nélson Gonçalves, a implantação do Veículo Leve sobre Trilhos (VLT) no centro pode estimular a construção de edifícios com menos vagas de garagem, reduzindo os preços. "A ideia é fazer com que o valor chegue perto do disponível na linha de financiamento e que as famílias que ganham entre 7 e 10 salários-mínimos possam arcar com os custos” (MARTINEZ, 2017). A declaração demonstra o interesse em atrair empreendimento de mercado popular para os bairros centrais. Mesmo que o programa Alegra Centro não tenha tido como resultado o retorno das 
residências de classes de rendimentos médios para os bairros centrais, ele modificou a configuração desses bairros, com o aumento do número de empresas, a mudança de determinados pontos comerciais e a criação de estabelecimentos de entretenimento noturno. $\mathrm{E}$ a discussão para as futuras mudanças das legislações aponta na direção de incentivos ao mercado imobiliário residencial para os próximos anos.

No entorno das Áreas de Proteção Cultural foram construídos na última década o Tribuna Square (figura 16), torre de escritórios da TV Tribuna (filiada da Rede Globo), com 55 mil $\mathrm{m}^{2}$; um prédio de escritórios da Cyrela e também o Valongo Brasil, empreendimento da Odebrecht com 329 escritórios, os três próximos à APC 1. Além destas torres, foi inaugurado em 2016 um hotel Ibis no Valongo, com 15 andares e 240 quartos. Esses empreendimentos indicam uma valorização dos terrenos nos bairros centrais.

Essas novas e envidraçadas torres produzem um enorme contraste com o entorno de prédios baixos e antigos, a maioria malcuidados, pois os inquilinos de cortiços fazem alguns pequenos reparos, mas não têm recursos para realizar reformas mais estruturais e há descaso da maioria dos proprietários; alguns estão abandonados e em ruínas, como podemos ver na figura 16, num trecho da Rua Amador Bueno a cerca de 150 metros do Tribuna Square.

Figura 16: Torre da TV Tribuna - Santos-SP.

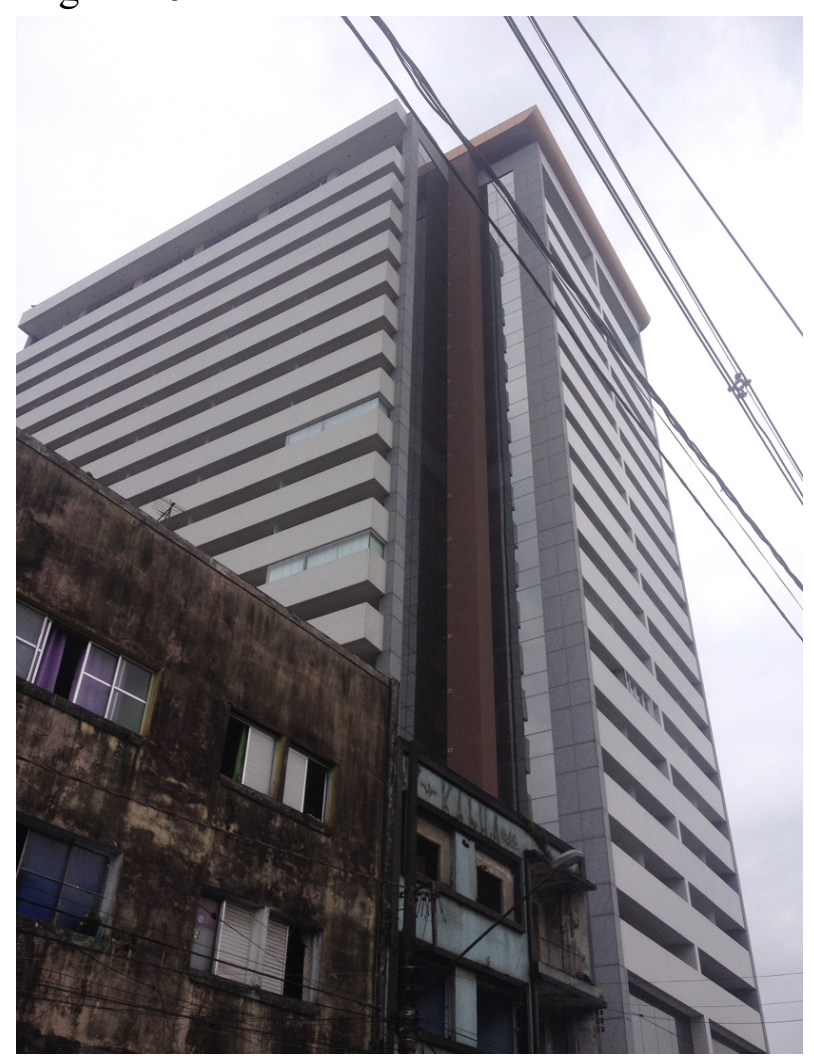

Fonte: Bruna G. Eskinazi - novembro de 2016. 
Figura 17: Imóveis da Rua Amador Bueno - Santos-SP.

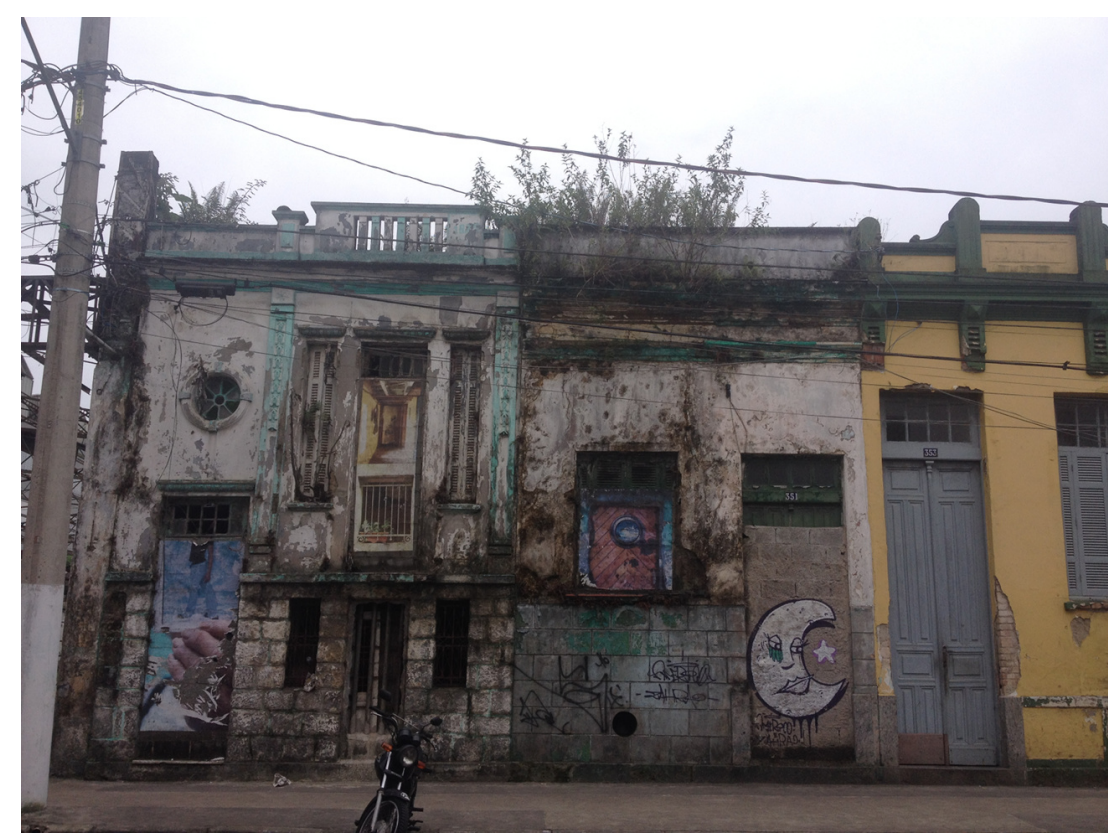

Fonte: Bruna G. Eskinazi - novembro de 2016.

Apesar da grande expansão de imóveis comerciais no centro de Santos, a procura está aquém do esperado. A ociosidade de muitas unidades levou a uma queda de $27 \%$ no preço do metro quadrado desde o lançamento (REIS, 2015). Edifícios comerciais e residenciais foram lançados em várias regiões da cidade em um momento de expansão do mercado imobiliário em Santos e de expectativas de um grande crescimento econômico da cidade com a descoberta do pré-sal ${ }^{45}$ em 2006. Esse crescimento não ocorreu como esperado e a crise econômica a partir de meados de 2014 frustrou as perspectivas do mercado imobiliário. Entre março de 2009 e março de 2012 foram lançadas 7.707 unidades residenciais, acentuando a contradição entre a quantidade de imóveis vagos e a grande parcela da população que vive em moradias precárias. Apesar das perspectivas da Prefeitura de incentivar a construção de residências voltadas para o mercado popular nos bairros centrais, a dificuldade de arcar com longos financiamentos em épocas de crise, e mesmo o risco de perda do imóvel em caso de desemprego, é uma realidade também para famílias de rendimentos médios, que muitas vezes comprometem uma parcela relevante de seus salários com o financiamento da casa própria.

Em 2014, a Petrobras entrou com processo no Conselho de Defesa do Patrimônio Histórico, Arqueológico, Artístico e Turístico (Condephaat) para revogar o tombamento de um

45 Reservas petrolíferas em profundidades de 1.000 a 2.000 metros abaixo da lâmina d'água, com importante reservatório na Bacia de Santos. 
armazém do século XIX. O processo foi aprovado (com irregularidades nos procedimentos) e dois terços do armazém foram demolidos. O projeto para a nova sede da estatal contava com três torres, mas somente uma foi construída, tendo suas atividades iniciadas em outubro de 2014.

Este processo de destombamento pode ser interpretado como o que Scifoni (2015) denomina de "ajuste do patrimônio": alterações integrais ou pontuais no corpus legal de preservação, ou até mesmo intervenções no patrimônio que ignoram requisitos fundamentais da sua proteção. Dessa forma, o patrimônio que se tornou um obstáculo para a produção desse empreendimento foi ajustado para que este pudesse se concretizar. É interessante notar que em um mesmo contexto o patrimônio pode servir de meio e motivação para intervenções urbanas, mas também pode ser obstáculo a determinados interesses.

As modificações nos bairros causadas por estes empreendimentos podem ter influenciado o valor dos aluguéis dos cômodos nos cortiços, que atualmente podem chegar a um saláriomínimo. O que torna difícil a manutenção das famílias nesses bairros, que gastam uma parcela significativa de seus rendimentos no aluguel de habitações tão precárias.

O espaço aparece e é vivido de forma distinta quando a habitação torna-se uma mercadoria, quando o ato de habitar passa a ser destituído de sentido, decorrente do fato de que os homens se tornaram instrumentos no processo de reprodução espacial, e suas casas se reduzem à mercadoria, passíveis de ser trocadas ou derrubadas (em função das necessidades do crescimento econômico) (CARLOS, 1999, p. 65).

Quando a casa torna-se uma mercadoria, como aponta Carlos, a permanência dos moradores em seus domicílios se torna mais instável, sobretudo com as populações em maior vulnerabilidade social como no caso dos moradores de cortiços em que apenas 15\% (segundo Censo dos moradores de cortiços) das famílias tem contrato de locação. A estabilidade da residência no cortiço não é garantida, muito pelo contrário: o medo do despejo é uma constante, e os preços crescentes dos aluguéis e a possibilidade de os proprietários darem outro destino aos seus imóveis (transformando-os talvez em cafés, restaurantes ou lojas, com apoio fiscal da Prefeitura) aumentam a insegurança dessas famílias. Apesar de suas habitações serem precárias, há a facilidade de viver no centro, próximo às ofertas de trabalho (economizando assim no transporte) e aos equipamentos públicos, como escola e postos de saúde. A saída dessas moradias, seja por despejo ou por impossibilidade de pagar os aluguéis crescentes, afastaria essas famílias dos bairros centrais, empurrando-as para as periferias, 
diminuindo seu acesso ao trabalho e aos equipamentos sociais. ${ }^{46}$

Cabe apontar que, de acordo com o indicador FipeZap, que analisa preços de locação e venda de imóveis em 15 cidades brasileiras, em Santos se encontra a maior rentabilidade de locação residencial (6,4\% em 2017: razão entre o preço do aluguel e o preço de venda do imóvel em $\mathrm{R} \$ / \mathrm{m}^{2}$, multiplicada por 12) do Brasil, e o quarto maior preço de aluguel por $\mathrm{m}^{2}$, atrás somente de São Paulo, Rio de Janeiro e do Distrito Federal. Por mais que esse indicador verifique somente o mercado formal de aluguéis, excluindo assim os cortiços, o fato de o aluguel formal ser alto em Santos pressiona para cima o valor dos aluguéis de cortiços.

O enfoque do programa Alegra Centro não é a questão habitacional, e quando a Prefeitura foi pressionada para incluir essa questão na agenda do programa, não o fez de maneira bemsucedida. A população moradora do centro, que apelidou o programa de "entristece centro" não estava satisfeita com a contradição de uma lei que propunha a restauração da fachada, enquanto do lado de dentro se continuava a morar precariamente. O Alegra Centro Habitação teve a realização de seus objetivos impedida pela falta de interesse em investir dos proprietários dos cortiços e pelo fato de que não buscou praticar em imóveis subaproveitados ou abandonados o IPTU progressivo no tempo e as possíveis desapropriações para disponibilizar terrenos para Habitação de Interesse Social (HIS).

Há uma contradição no reconhecimento do valor histórico de um conjunto de edificações que são subdivididas para multiplicar a sua rentabilidade ao mesmo tempo em que recebem o mínimo de investimentos na sua manutenção, das quais a fachada (objeto da política de preservação) é apenas indicativo da situação de habitabilidade bastante precária. A Prefeitura, ao oferecer isenção de impostos para incentivar o restauro da fachada sem questionar as condições internas das moradias, coloca o objetivo de atrair turistas e estimular atividades de lazer acima dos direitos básicos dos moradores dos cortiços. A APC 2 se sobrepõe em alguns quarteirões à Zeis 3, delimitada 11 anos antes e sem políticas públicas que melhorassem a condição das habitações. A delimitação da APC 2 em nenhum momento considerou que o objetivo primeiro daquela área deveria ser - como determinado na legislação - a habitação de interesse social.

Apresentaremos mais adiante algumas políticas públicas que têm o objetivo de conciliar a preservação e as políticas de habitação. Infelizmente são poucos os casos no Brasil.

46 Lembrando que nas áreas encortiçadas, como indica a figura 9, predominam os índices de vulnerabilidade social média e alta, grupos que têm rendimento médio por domicílio, respectivamente, de R\$1.760,00 e R\$ $1.512,00$ 
A seguir, discutiremos os conjuntos habitacionais populares na cidade de Santos, para poder analisar de forma mais abrangente as políticas públicas para habitação lá realizadas. 


\section{Capítulo 2: Políticas públicas de habitação em Santos-SP}

Quando o oficial de justiça chegou

Lá na favela

E contra seu desejo

Entregou pra seu Narciso

Um aviso, uma ordem de despejo

- Assinada, seu doutor, Assim dizia a petição:

"Dentro de dez dias

Quero a favela vazia

E os barracos todos no chão"

Adoniran Barbosa

O deficit habitacional em Santos é um problema desde o final do século XIX, quando a população da cidade começou a crescer, sem haver uma disponibilidade de casas compatível. A única possibilidade de moradia para grande parte dos trabalhadores (em especial os portuários) era os cortiços. Essa situação era agravada pelas já mencionadas crises de abastecimento de água e pelas epidemias, que vitimaram mais de 20 mil pessoas na última década do século XIX.

Gráfico 2: Evolução da população no município de Santos-SP, ${ }^{47}$ de 1790 a 2010

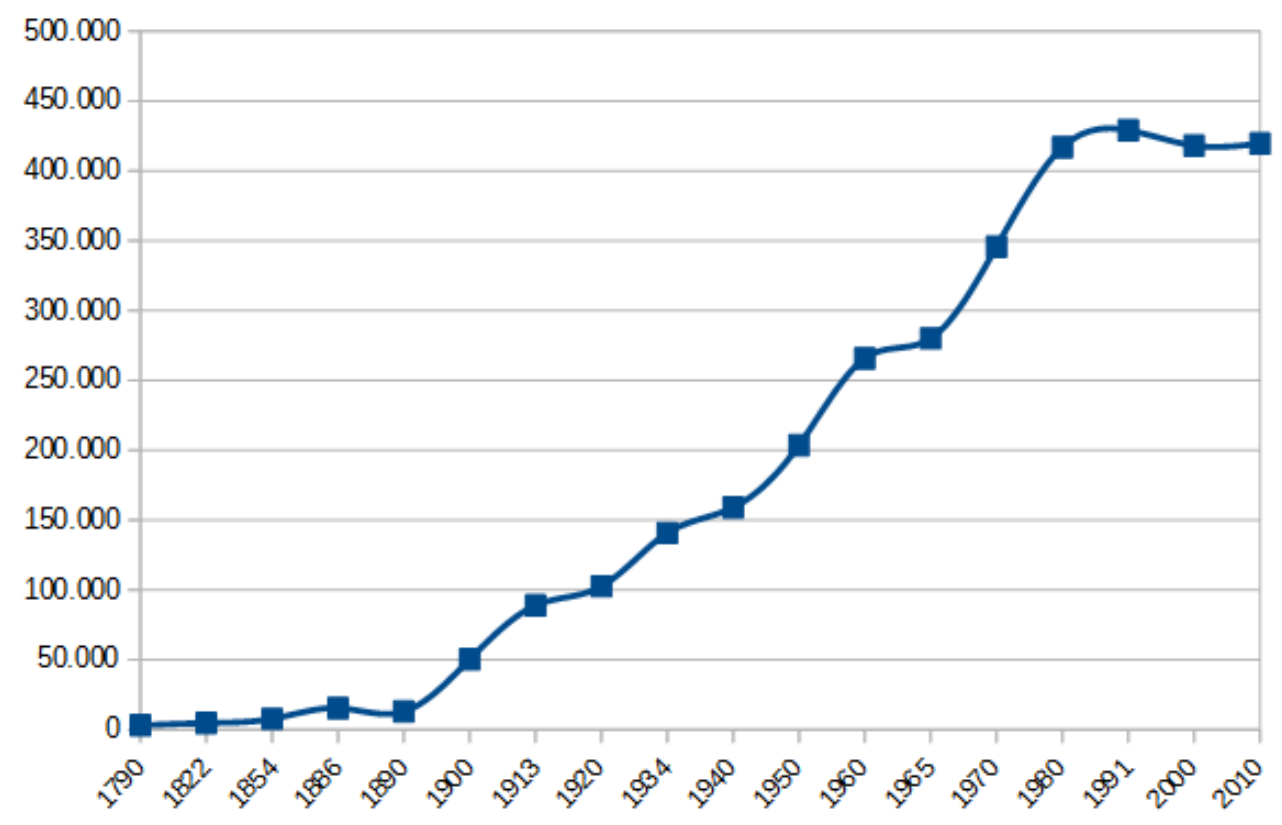

Fonte: Elaborado com dados do Censo e de Araújo Filho, Barbosa, Gitahy e Lopes.

47 Apontamos que o distrito de Bertioga desmembrou-se como município em 1993, e possuía nos anos de 2000 e 2010 uma população de, respectivamente, 30.039 e 47.645 habitantes. 
Os cortiços seguem sendo uma realidade em Santos (ainda que tenham mudado os bairros de sua maior concentração, como demonstra o mapa 4 no capítulo 1).

Os Institutos de Aposentadorias e Pensões (IAPs) foram criados a partir de 1933 pelo governo Getúlio Vargas, ${ }^{48}$ com as mesmas funções das Caixas de Aposentadoria e Pensões, mas com um número ampliado de beneficiários. Foram criados como autarquias e estavam ligados a determinadas categorias profissionais, para organizar o sistema previdenciário.

Esses institutos tinham como objetivos: garantir a aposentadoria e pensões dos beneficiários, atendimento à saúde, e, por fim, a produção habitacional. Eram autorizados a utilizar até metade de suas reservas financeiras para inversões imobiliárias, dando condições mais favoráveis de financiamento, com prazos de pagamentos longos e juros mais baixos. Os financiamentos eram concedidos em vários planos diferentes, podendo ser para compra de terreno, construção ou reforma de casa, ou para a compra de apartamentos ou casas dos conjuntos habitacionais. Muitos desses imóveis eram alugados pelos institutos para os associados que não tinham condições financeiras de arcar com o financiamento. Cada instituto era ligado a uma determinada categoria profissional e os trabalhadores que não pertenciam a essas categorias ou não tivessem emprego formal não podiam se beneficiar de suas ações. Os projetos dos IAPs deviam garantir moradia digna e aluguel reduzido, ainda que rentável ${ }^{49}$ para os fundos do instituto. Dessa forma, o cuidado com materiais de construção e processos de qualidade era muito grande por parte dos técnicos, e os projetos eram desenhados pensando na durabilidade e na facilidade de manutenção. Assim, os institutos formaram um patrimônio imobiliário significativo, além de um banco de terras para a construção de novos empreendimentos.

Ainda que a produção habitacional dos institutos seja heterogênea, de forma geral eles adotaram uma visão bastante moderna das moradias: "formulação do projeto de uma unidade habitacional racional e econômica, que viabilizava a ideia da habitação mínima, onde a cozinha, por exemplo, devia ter uma área exígua. Nessa perspectiva, os arquitetos militavam por uma nova cultura do morar, relacionada com o desenvolvimento e modernização do país" (BONDUKI, 2012, v.1, p. 53).

Os seis IAPs juntos foram responsáveis pela construção de mais de 47 mil unidades habitacionais (UH) em conjuntos habitacionais e mais de 76 mil UH espalhadas por todo o

48 Alguns institutos, como o dos comerciários e o dos bancários, foram criados antes do Estado Novo, e outros durante o regime ditatorial, como o Instituto de Previdência e Assistência dos Servidores do Estado (Ipase) e o Instituto de Aposentadoria e Pensões dos Empregados em Transportes e Cargas (IAPETC).

49 O congelamento dos aluguéis em 1942 dificultou esse retorno financeiro. Na prática, em tempos de inflação alta, a falta dos reajustes acabou por subsidiar os custos de moradia dos beneficiários e onerar os institutos. 
país, como demonstra a tabela 1 .

Tabela 1: Promoção de unidades habitacionais por entidades públicas no Brasil (1930-1964)

\begin{tabular}{|c|r|r|r|}
\hline Órgão Promotor & $\begin{array}{c}\text { UHs em conjuntos } \\
\text { residenciais }\end{array}$ & $\begin{array}{l}\text { Financiamento para } \\
\text { construção ou } \\
\text { aquisição }\end{array}$ & $\begin{array}{c}\text { UHs financiadas e } \\
\text { construídlas }\end{array}$ \\
\hline IAPI - Industriários & 19.779 & 17.219 & 36.998 \\
\hline IAPC - Comerciários & 12.917 & 16.219 & 29.136 \\
\hline IAPB - Bancários & 5.511 & 12.347 & 17.858 \\
\hline IPASE - Servidores Públicos & 6.361 & $\mathbf{s} / \mathrm{i}$ & 6.361 \\
\hline IAPETC - Transportes e Cargas & 3.473 & 2.917 & 6.390 \\
\hline IAPM - Marítimos & 1.345 & 2.451 & 3.796 \\
\hline IAPFESP - Serviços públicos & 1.603 & 25.053 & 26.656 \\
\hline Total IAPs & $\mathbf{5 0 . 9 8 9}$ & $\mathbf{7 6 . 2 0 6}$ & $\mathbf{1 2 7 . 1 9 5}$ \\
\hline FCP - Fundação Casa Popular & 19.156 & & 19.156 \\
\hline DHP - Departamento de Habitação Popular & 755 & & 755 \\
\hline Outros órgãos regionais & 5.954 & & 5.954 \\
\hline Áreas residenciais das cidades novas & 22.000 & & $\mathbf{1 7 5 . 0 6 0}$ \\
\hline Total Geral & $\mathbf{9 8 . 8 5 4}$ & $\mathbf{7 6 . 2 0 6}$ & \\
\hline
\end{tabular}

Fonte: BONDUKI, 2012, v.1, p. 50 (adaptado).

Figura 18: Fotografia aérea do Conjunto Residencial Enguaguaçu, Santos-SP, 1970.

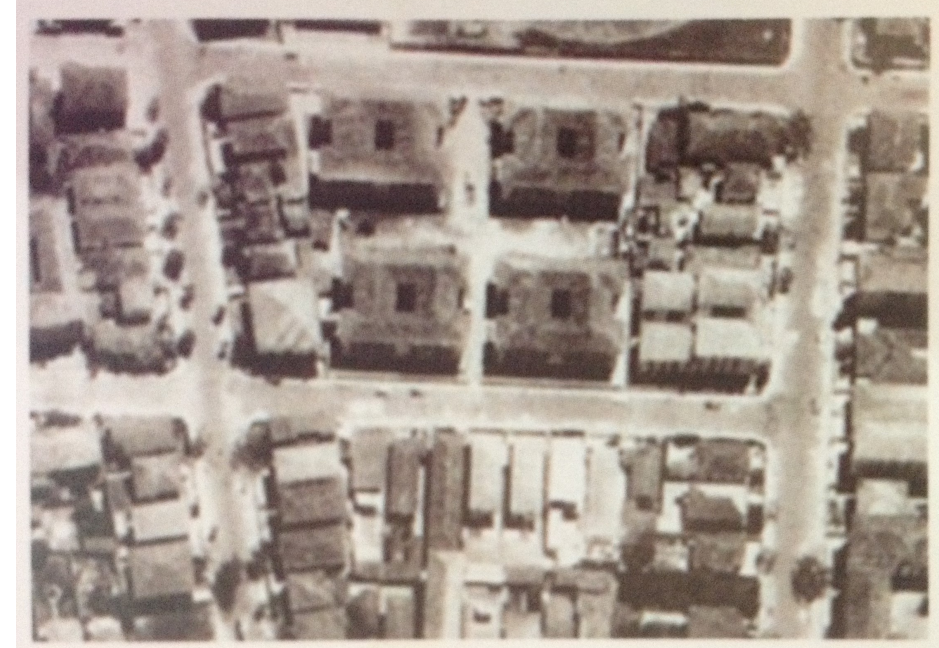

Fonte: BONDUKI, N.; KOURY, A. P., 2012, v.2, p. 280.

Os IAPs iniciaram a construção de conjuntos habitacionais em Santos a partir dos anos 1940.

O Conjunto Residencial Enguaguaçu, no bairro Aparecida, foi construído na década de 1940 pelo Instituto de Aposentadoria e Pensões dos Empregados em Transportes e Cargas (IAPETC). Compreende quatro blocos de três pavimentos cada, com 96 apartamentos de 61 $\mathrm{m}^{2}$. O bairro na época era pouco habitado, muito afastado do centro, e as ruas não possuíam pavimentação; após a construção, o conjunto ficou fechado por dez anos à espera da instalação da rede de esgoto, normalmente a infraestrutura é responsabilidade das municipalidades, o atraso denota uma falta de coordenação entre as ações dos diferentes poderes públicos. 
Figura 19: Vista geral do Conjunto Residencial Enguaguaçu, Santos-SP.

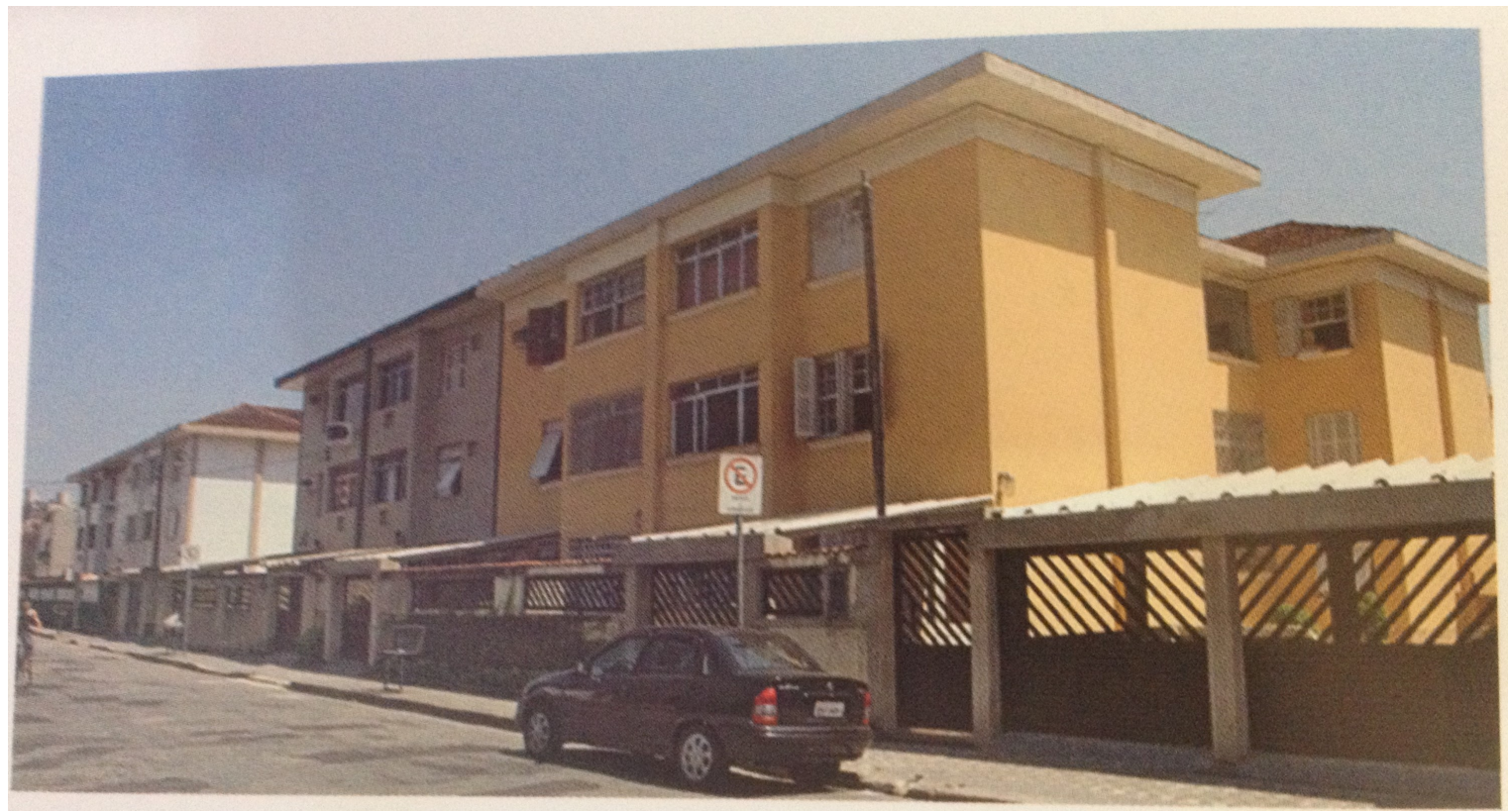

Fonte: HAYAKAWA, R. M. apud BONDUKI, N.; KOURY, A. P., 2012, v.2, p. 280.

A Vila dos Portuários foi construída, também na década de 1940, no bairro Embaré. Financiadas pela Caixa de Aposentadoria e Pensões dos Portuários, eram 22 casas em fileira de um dormitório, com $31 \mathrm{~m}^{2}$.

Figura 20: Planta da casa da Vila dos Portuários, Santos-SP.

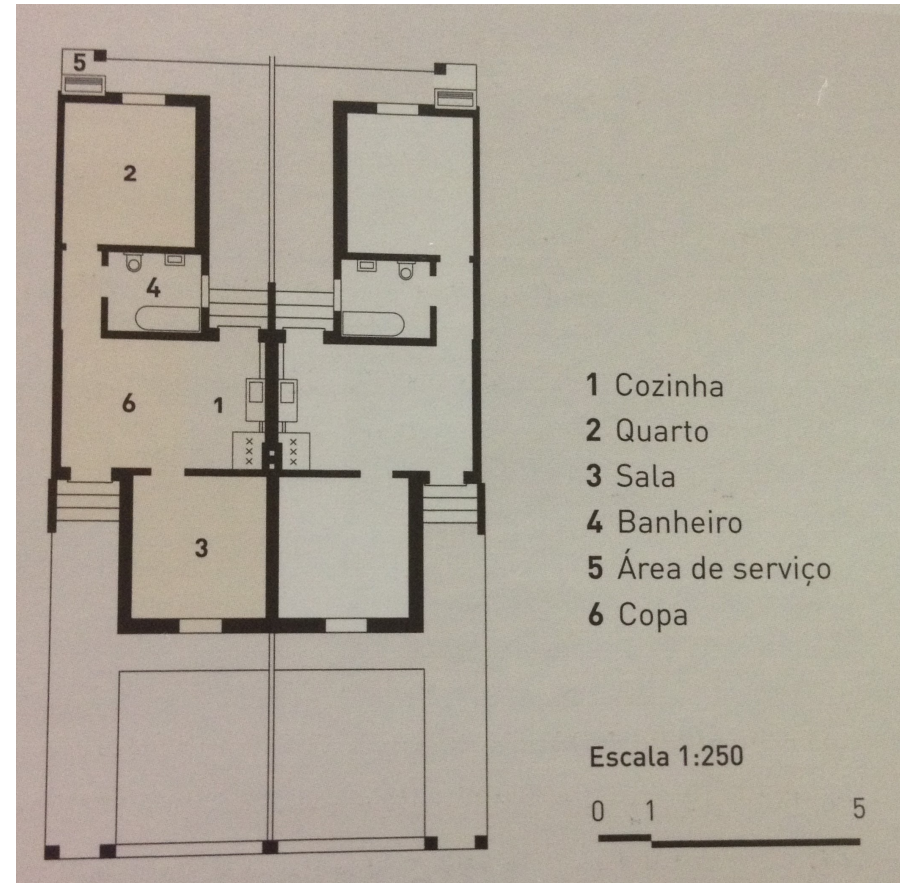

Fonte: Acrópole, ano III, n 28, agosto, 1940 apud BONDUKI, N.; KOURY, A. P., 2012, v.2, p. 315. 
Figura 21: Vista de remanescente da Vila dos Portuários, Santos-SP.

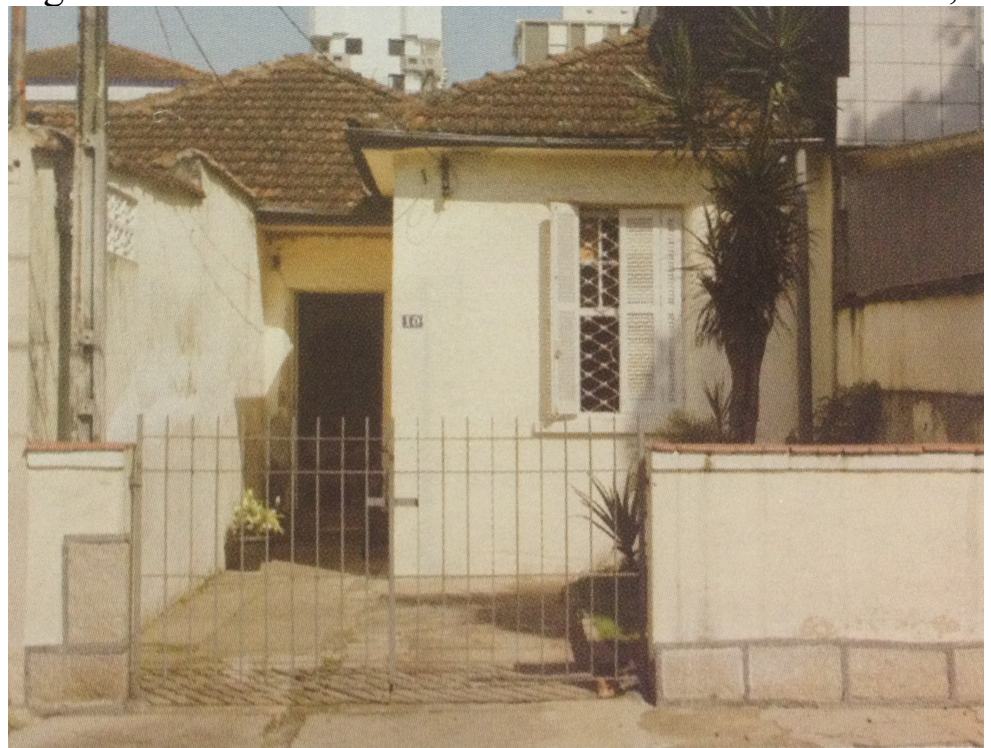

Fonte: HAYAKAWA, R. M., 2006 apud BONDUKI, N.; KOURY, A. P., 2012, v.2, p. 315.

Em 1943 foi entregue o Conjunto Residencial do Instituto de Aposentadorias e Pensões dos Bancários (IAPB). Era o instituto de aposentadorias com maior verba por associado e isso se refletia na qualidade e no tamanho das casas. As casas que foram construídas em Santos possuíam as mesmas plantas dos conjuntos do IAPB em São Paulo, de 2, 3 ou 4 dormitórios, com até $87 \mathrm{~m}^{2}$. Mais da metade da produção do Instituto dos Bancários foi realizada no Estado de São Paulo.

No mesmo ano foi entregue a Vila de Santos, de dimensões mais modestas, com plantas de 40, 55 e $56 \mathrm{~m}^{2}$, financiada pelo IAPETC. Foram construídas 84 unidades, mas os levantamentos de campo realizados nas décadas de 1990 e 2000 não localizaram o conjunto (BONDUKI; KOURY, 2012).

Figura 22: Casa do Conjunto Residencial do IAPB, Santos-SP.

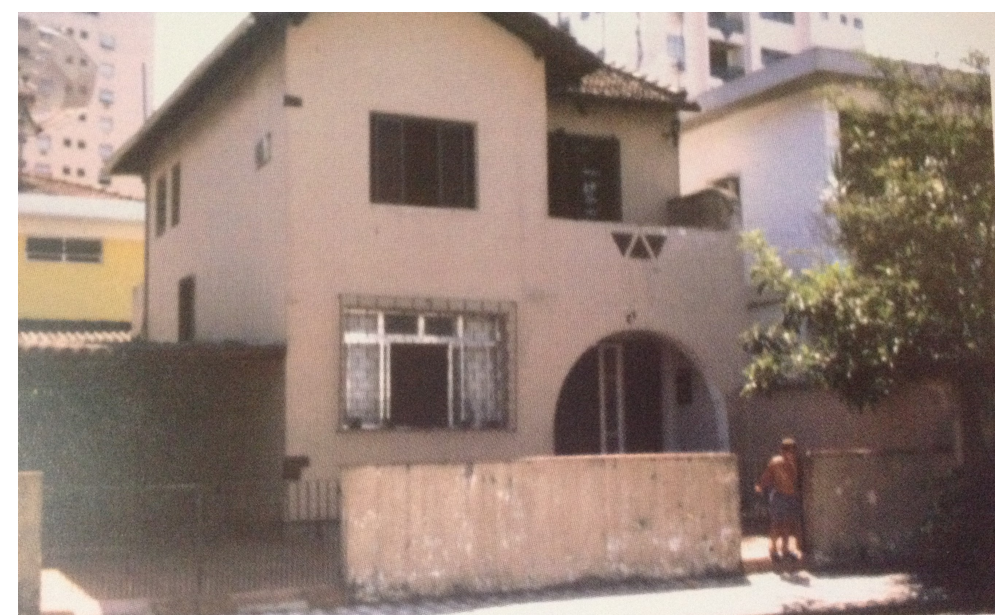

Fonte: BONDUKI, N.; KOURY, A. P., 2012, v.2, p. 182. 
Figura 23: Plantas da Vila de Santos, Santos-SP.

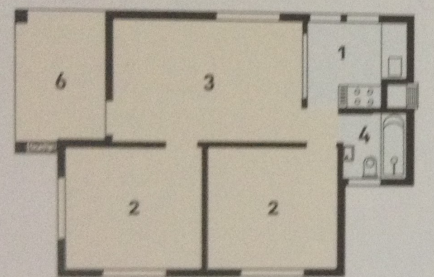

Tipo $\mathrm{Cl1}$

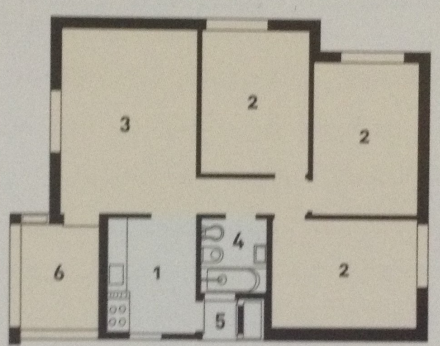

Tipo $\mathrm{Cl} 2$

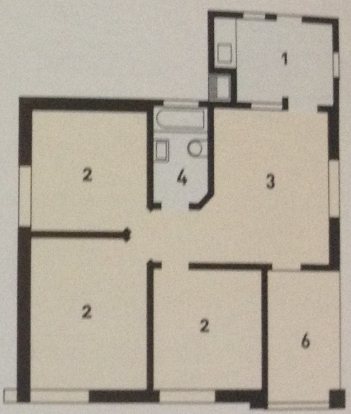

Tipo $\mathrm{Cl} 3$

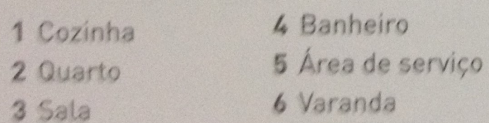

Escala 1:250

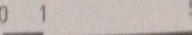

Fonte: Acrópole, ano V, nº 57, 1943 apud BONDUKI, N.; KOURY, A. P., 2012, v.2, p. 284.

Os Núcleos Residenciais de Santos foram fruto de uma parceria entre a Fundação Casa Popular (FCP) e a Prefeitura de Santos, que desapropriou terrenos próximos à zona portuária e ficaria responsável pela urbanização da área, enquanto a FCP se responsabilizava pela construção de 343 casas, divididas em 5 núcleos. No entanto, só foram construídas 200 unidades, com três tipologias distintas, de 42, 47 e $48 \mathrm{~m}^{2}$. As primeiras unidades foram inauguradas em maio de 1948. Os núcleos estão localizados nos bairros Embaré, Boqueirão e Estuário.

Figura 24: Plantas dos Núcleos Residenciais de Santos, Santos-SP.

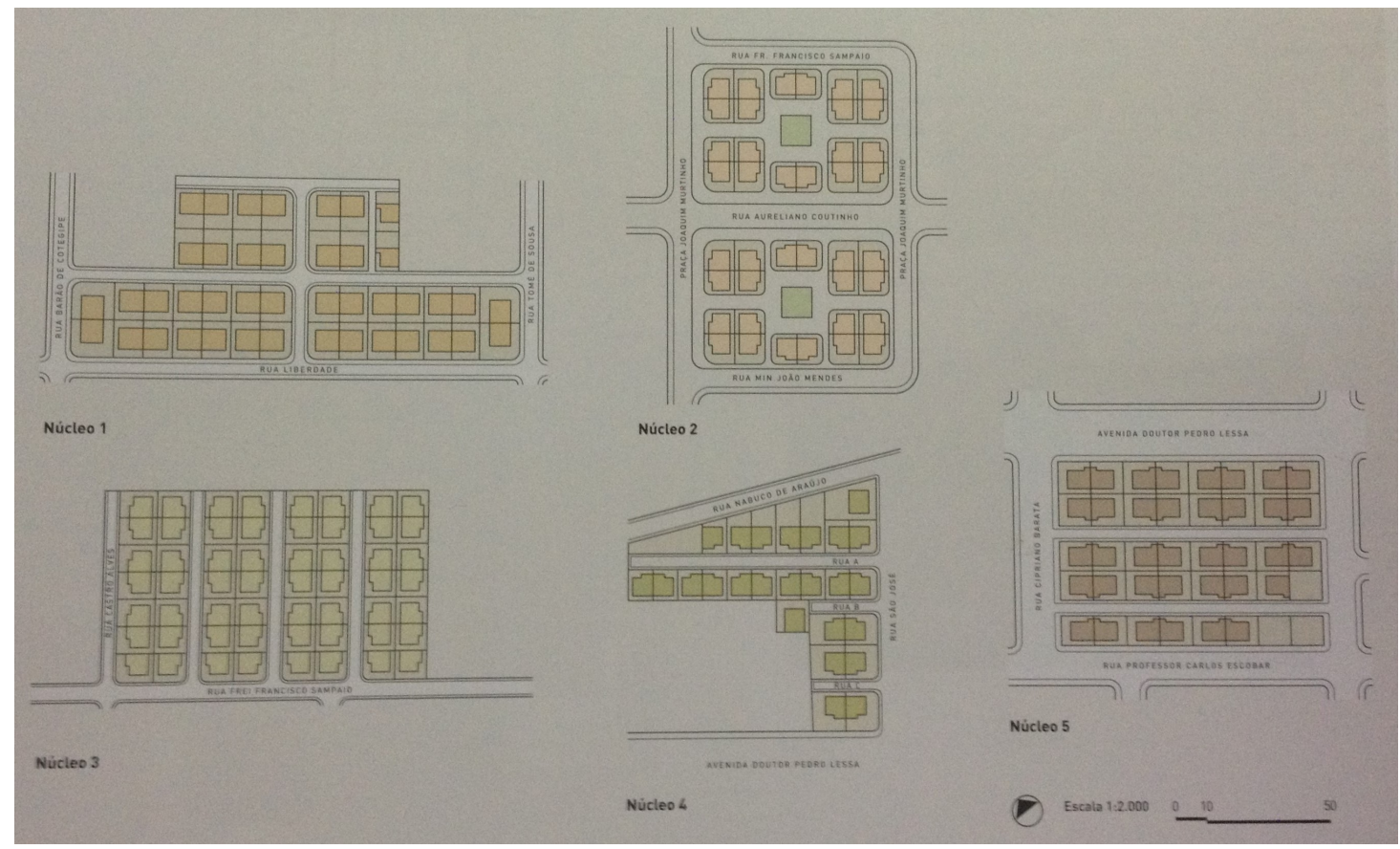

Fonte: MANOEL, S. K. apud BONDUKI, N.; KOURY, A. P., 2012, v.2, p. 327. 
O Núcleo Residencial Bacia do Macuco foi o primeiro empreendimento da FCP, anunciado logo após a sua criação pelo presidente Eurico Gaspar Dutra e por ele inaugurado em 1949. A construção das 536 casas geminadas deste conjunto habitacional foi uma resposta à mobilização dos trabalhadores portuários.

Como a maior parte dos empreendimentos da FCP, o terreno foi desapropriado pela Prefeitura para ser doado ao órgão, localizando-se, não por acaso, no Macuco, bairro portuário que foi palco de grandes agitações sociais no período. A região não dispunha de saneamento, era precariamente urbanizada e fortemente ocupada por trabalhadores de baixa renda, que viviam em casas construídas por eles próprios ou em moradias de aluguel de propriedade de particulares. (...) Antigos moradores ainda hoje reclamam da dimensão dos cômodos e das portas. O banheiro equipado apenas com vaso sanitário demonstra a falta de físcalização ou o baixo padrão adotado. Como os demais conjuntos da FCP, as casas apresentam-se muito modificadas, sendo difícil identificar unidades originais (BONDUKI, N.; KOURY, A. P. 2012, v.2, p. 325).

Segundo Bonduki e Koury, este conjunto residencial, dentre outros do mesmo período, teve uma forte relação com as movimentações dos trabalhadores portuários, categoria muito influenciada pelo Partido Comunista Brasileiro (PCB); assim a casa própria servia como um contraponto às mobilizações no porto.

Figura 25: Planta do Núcleo Residencial Bacia do Macuco, Santos-SP.

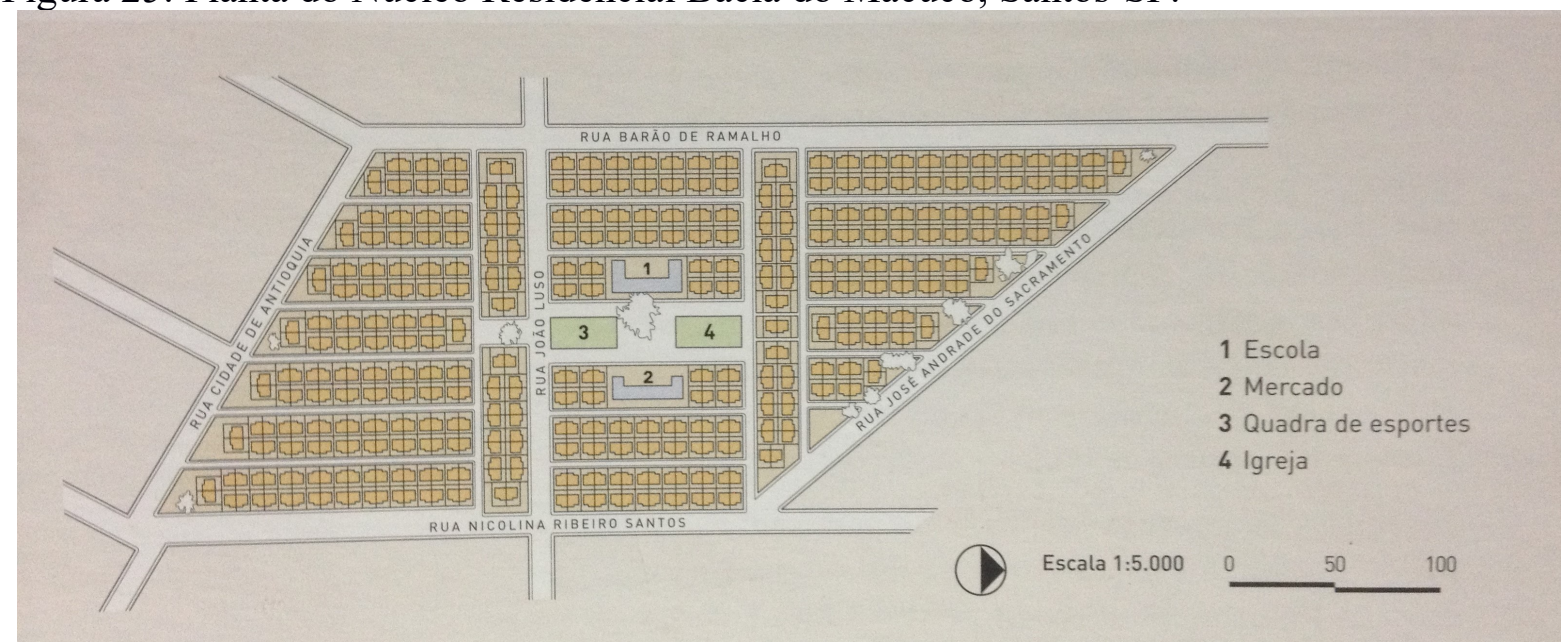

Fonte: MANOEL, S. K. apud BONDUKI, N.; KOURY, A. P., 2012, v.2, p. 325. 
Figura 26: Planta da casa do Núcleo Residencial Bacia do Macuco, Santos-SP.

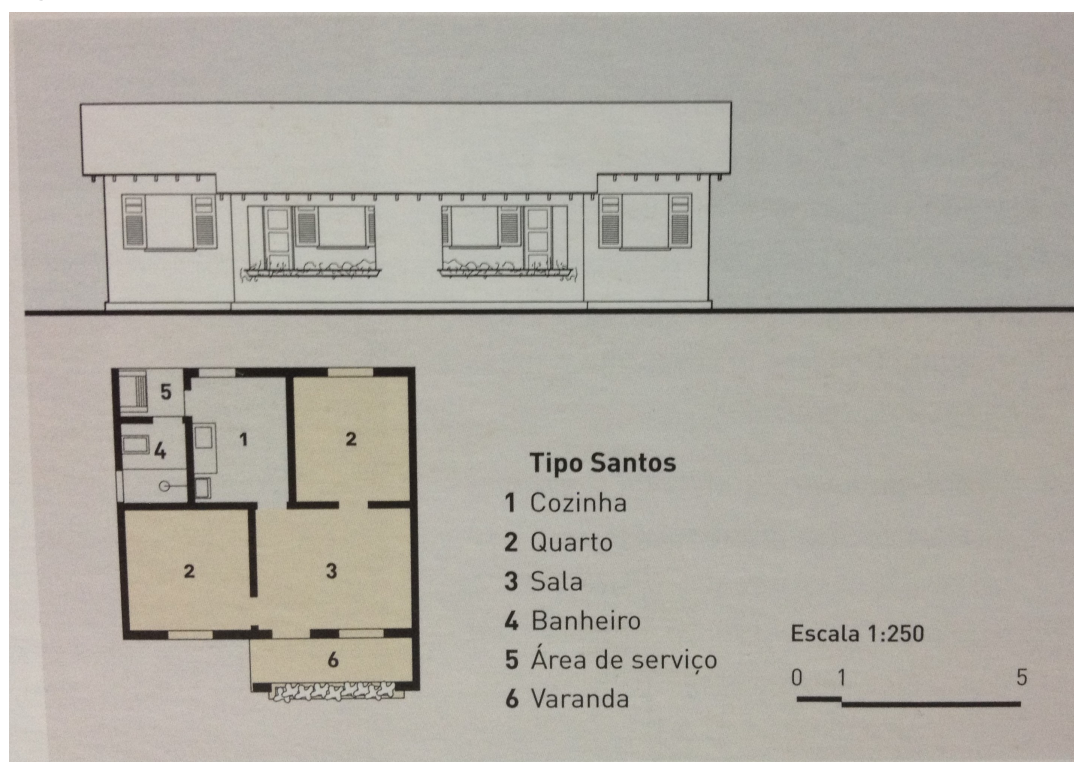

Fonte: MANOEL, S. K. apud BONDUKI, N.; KOURY, A. P., 2012, v.2, p. 325.

Figura 27: Vista de rua interna do Núcleo Residencial Bacia do Macuco, Santos-SP.

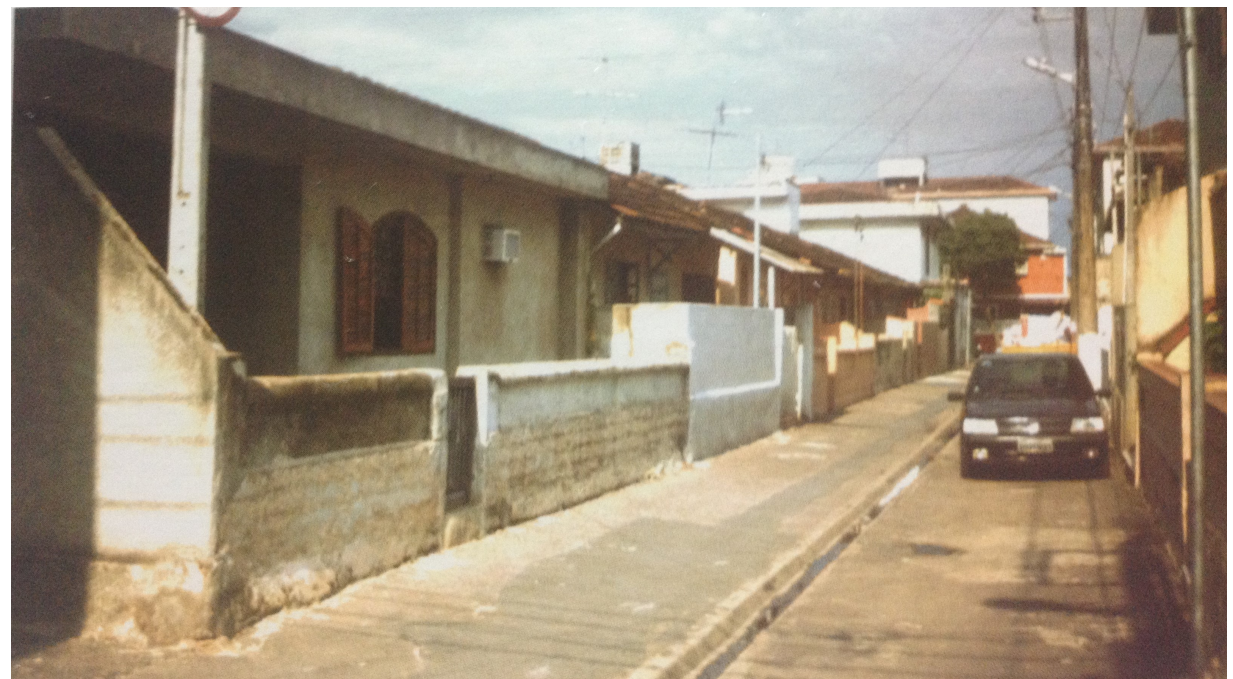

Fonte: MANOEL, S. K. apud BONDUKI, N.; KOURY, A. P., 2012, v.2, p. 325.

A FCP foi pensada inicialmente para realizar a política habitacional para a população de baixos rendimentos (independentemente da categoria profissional, ao contrário dos IAPs). No entanto, alguns meses depois de sua criação, ela se tornou um órgão de política urbana, sendo de sua responsabilidade a infraestrutura urbana em geral e ainda o financiamento da indústria da construção civil. Mas tais objetivos se mostraram inatingíveis por diversos motivos, dentre eles a incapacidade da fundação para captar recursos, pois uma série de dispositivos para arrecadação falhou. Assim a responsabilidade pela infraestrutura ficou a cargo das municipalidades, e também, frequentemente, a doação do terreno. A produção da FCP foi relativamente pequena, até 1960 foram construídas quase 17 mil casas em todo o 
país (AZEVEDO; ANDRADE, 2011).

O Conjunto do Instituto de Aposentadorias e Pensões dos Industriários (IAPI) na Aparecida foi inaugurado em 1957, com 200 apartamentos de 2 e 3 dormitórios, com, respectivamente, 46 e $57 \mathrm{~m}^{2}$. O conjunto

previa originalmente 35 blocos de 4 pavimentos sobre pilotis, mas foram implantados apenas 5. Trata-se de um relevante exemplo da presença moderna na produção habitacional do IAPI na década de 1950, contemporânea à construção de Brasília, e que inova em relação aos projetos dos anos 1940. Os blocos foram organizados como lâminas paralelas, numa área pública aberta, com um generoso afastamento que permitia sua utilização para lazer e recreação dos moradores. A elevação dos blocos sobre pilotis cria uma continuidade do espaço público, colocando em prática a concepção corbusiana de cidade. (...) O conjunto sofreu muitas modificações, como o revestimento em ladrilho cerâmico, a eliminação dos cobogós, o cerramento dos blocos e a implantação de garagens nos espaços públicos, mudanças que subverteram estruturalmente as propostas originais (BONDUKI, N.; KOURY, A. P., 2012, v.2, p. 78)

$\mathrm{Na}$ área que não foi utilizada pelo conjunto do IAPI no bairro Aparecida, na década seguinte foi construído o conjunto habitacional do Banco Nacional de Habitação (BNH), como pode ser visualizado nas figuras 28 e 30 .

O Banco Nacional de Habitação foi criado em 1964, no início do regime militar, substituindo a Fundação Casa Popular, e inaugurando uma nova política habitacional. A criação do banco teve um duplo objetivo, apaziguar as tensões sociais urbanas, em especial daqueles que viviam em situações precárias, e impulsionar a economia com as construções, ampliar a oferta de trabalhos pouco qualificados e dar oportunidades para escritórios de engenharia, construtoras e indústrias de materiais de construção. O principal recurso do BNH foi o Fundo de Garantia do Tempo de Serviço (FGTS). Nos primeiros cinco anos, o banco financiou mais de 400 mil unidades em todo o país, totalizando 2,8 milhões até 1980. Destas, 1 milhão de unidades habitacionais foram destinadas ao mercado popular, pessoas que recebiam até cinco salários-mínimos.

Embora o atendimento à baixa renda não tenha sido irrisório, a ausência de um subsídio direto e as regras para obtenção de financiamento, restrito aos trabalhadores formais que pudessem comprovar um rendimento estável compatível com as condições de acesso ao crédito, limitaram enormemente o acesso aos recursos do Sistema Financeiro de Habitação (BONDUKI, 2012, v. 1, p. 65) 
Figura 28: Fotografia aérea dos conjuntos do IAPI e do BNH, Santos-SP, década de 1970.

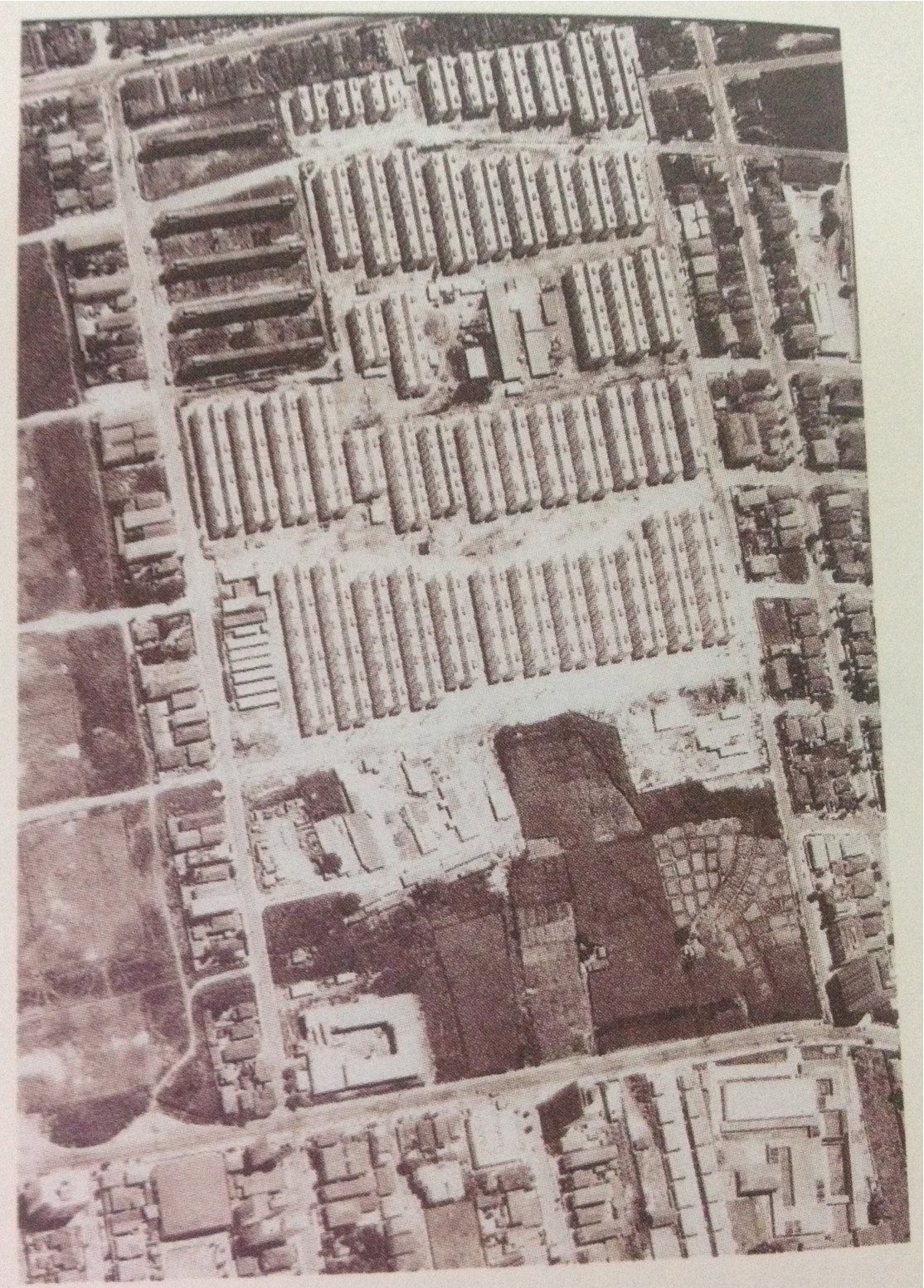

Fonte: Rev. dos Industriários, nº 60, dez. 1957, apud BONDUKI, N.; KOURY, A. P., 2012, v.2, p. 78. 
Figura 29: Conjunto do IAPI na sua inauguração, Santos-SP.

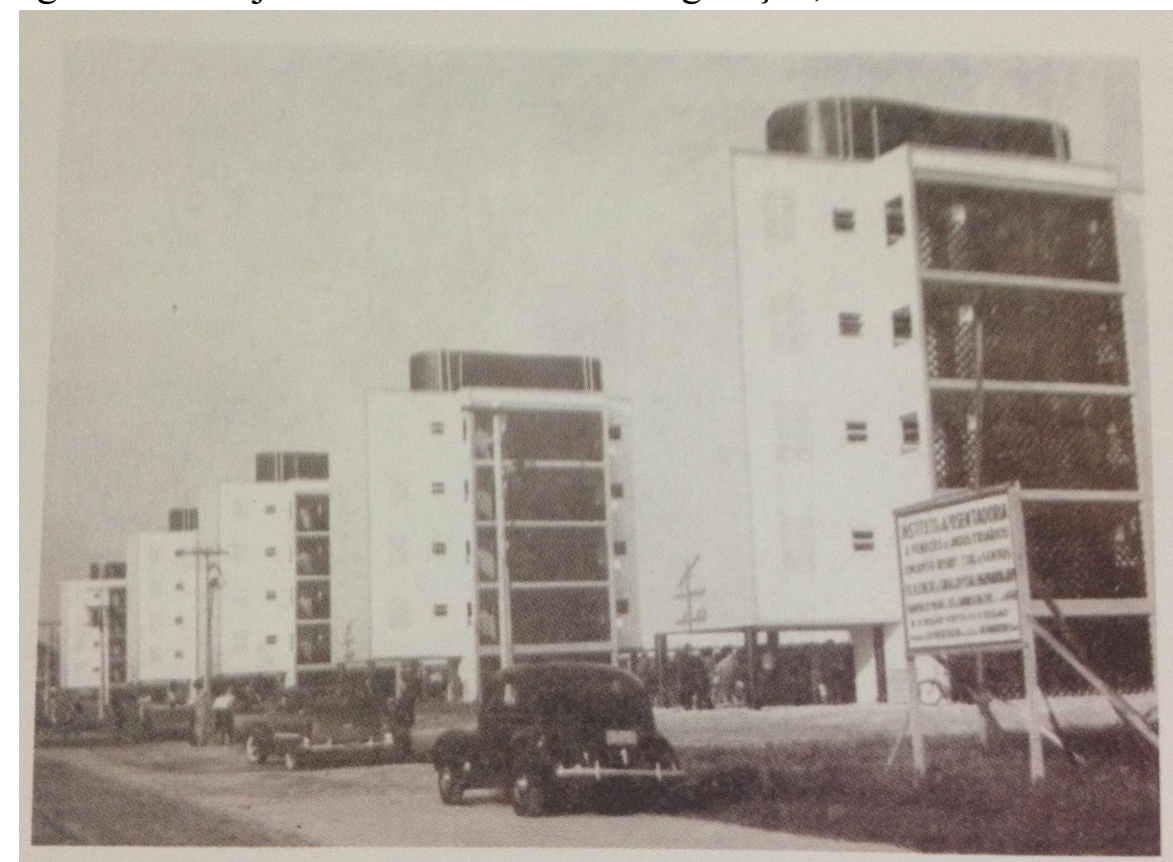

Fonte: Rev. dos Industriários, nº 60, dez. 1957, apud BONDUKI, N.; KOURY, A. P., 2012, v.2, p. 78. Figura 30: Vista dos conjuntos do IAPI e do BNH, Santos-SP, década de 1990.

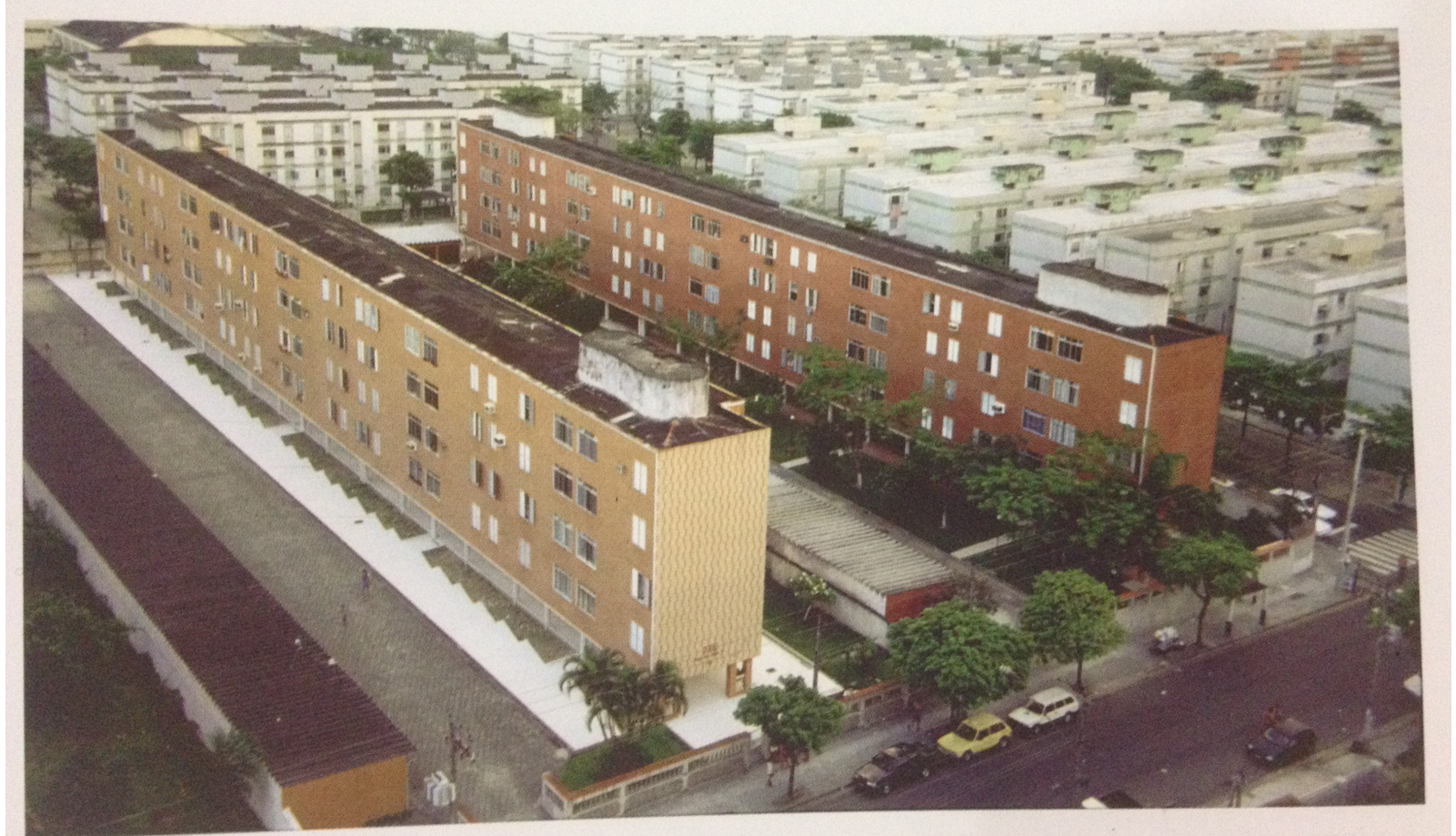

Fonte: BONDUKI, N.; KOURY, A. P., 2012, v.2, p. 79.

A produção habitacional do banco foi muito vasta, mas grande parte dos conjuntos apresentava certos problemas: como a porcentagem máxima do orçamento para a compra do terreno era reduzida, frequentemente os conjuntos eram construídos nas franjas urbanas, sem equipamentos públicos próximos e com acesso difícil ao centro da cidade. Não havia 
uma articulação com uma concepção urbanística ou soluções habitacionais que levassem em consideração as características climáticas e culturais do local, pelo contrário, os conjuntos eram extremamente padronizados, uma pobreza arquitetônica devida principalmente aos limites orçamentários.

Em Santos, o conjunto construído na década de 1960, na área que anteriormente seria para a construção dos demais blocos do conjunto do IAPI, na Aparecida, possuí 97 blocos de quatro pavimentos, totalizando 3.288 apartamentos (foto 29). O conjunto teve inúmeros problemas relativos às caixas d'água e ao sistema de esgoto nos primeiros anos após sua inauguração. Os conjuntos habitacionais do BNH eram de maneira geral muito inferiores em qualidade aos conjuntos dos IAPs; no caso de Santos, por exemplo, se compararmos o conjunto do IAPI com o do BNH na fotografia aérea, podemos perceber que os prédios do BNH estão muito mais próximos uns dos outros, com uma densidade construtiva alta, acarretando menores espaços livres e menos circulação do ar e insolação dos apartamentos. A alta densidade construtiva também significa que o BNH tem menores gastos com aquisição de terreno por unidade habitacional.

As Companhias de Habitação foram responsáveis por mais de 1 milhão de unidades residenciais no país, entre 1964 e 1980, sobretudo a partir de 1975. A Cohab da Baixada Santista, entre 1966, quando inaugurou o Conjunto Jardim Castelo, e 2012, foi responsável pela construção de 7.711 unidades residenciais em Santos, além de 8 mil unidades nos demais municípios da Baixada Santista.

Os conjuntos residenciais da Cohab em Santos diferem daqueles dos IAPs ou do BNH, pois estão localizados em bairros mais afastados do centro da cidade, principalmente na zona noroeste, região em que predominam as moradias precárias (e também os altos índices de vulnerabilidade, como se pode observar na figura 10, no capítulo 1).

A Companhia de Desenvolvimento Habitacional e Urbano (CDHU) - empresa do Governo Estadual de São Paulo, vinculada à Secretaria de Habitação - foi responsável por 10 empreendimentos habitacionais já finalizados no município de Santos. O último empreendimento da CDHU em Santos foi inaugurado em janeiro de 2018 e possui 133 UHs. Entre 1998 e 2016 foram entregues 2.177 unidades habitacionais em nove empreendimentos, dois dos quais estavam inseridos no Programa de Atuação em Cortiços (PAC). Os Conjuntos Santos F (figura 31) e Santos H, respectivamente nas Ruas João Pessoa e Amador Bueno, ambas no bairro Paquetá, totalizam 113 apartamentos, situados na Zeis 3 (que define o 
perímetro de concentração de cortiços). Outros dois empreendimentos estavam previstos pelo PAC, mas não saíram do papel - um deles, o Santos $\mathrm{I}^{50}$, já tem o terreno adquirido pela CDHU e está em fase de cadastro das famílias (figura 32). Este programa foi realizado pela CDHU somente nas cidades de São Paulo e Santos, que concentram a maior quantidade de cortiços do Estado. O programa foi criado para responder a uma demanda de famílias encortiçadas, organizadas na entidade Unificação das Lutas em Cortiços, que existe em São Paulo desde 1991. O PAC começou a ser desenvolvido em 1995 e foi instituído em 1998 pelo Decreto $\mathrm{n}^{\mathrm{o}} 43.132$ de $1^{\mathrm{o}}$ de junho, mas só firmou acordo para o financiamento externo em 2001 (ROYER, 2002), sendo que parte desse financiamento foi obtido do Banco Interamericano de Desenvolvimento (BID). O projeto inicial, de 2002, tinha um orçamento de US\$ 70 milhões, sendo US\$ 34 milhões financiados pelo BID e o restante seria a contrapartida da CDHU. Com a crise de 2008, o financiamento do BID foi reduzido para US\$ 23 milhões. As metas do programa tiveram que ser ajustadas, e com o andamento do projeto também se ajustou a capacidade de endividamento das famílias e foram aumentados os subsídios - dessa forma, a meta inicial de 5 mil famílias atendidas (nos dois municípios) passou para 2.740. Essa meta foi atingida em 2011 e o programa chegou à cifra de 3.080 UHs em 2013, incluindo 870 cartas de crédito para compra de imóveis no mercado.

O diferencial deste programa é o levantamento da demanda por setores (em São Paulo foram definidos oito setores e em Santos um) e o direcionamento das famílias para empreendimentos localizados no mesmo setor, evitando a mudança de bairro. Os imóveis também são diferenciados da tipologia geralmente adotada pela CDHU nas periferias, de grandes conjuntos em grandes terrenos. Como nos bairros mais centrais há maior possibilidade de adquirir terrenos menores e como as famílias moradoras de cortiços costumam ser menos numerosas, os empreendimentos do PAC são mais reduzidos e os apartamentos, de um ou dois dormitórios. A maior parte dos prédios tem menos de 100 UHs. O empreendimento Santos F tem 60 apartamentos (42 de um dormitório com $34 \mathrm{~m}^{2}$ e 18 de dois dormitórios com $42 \mathrm{~m}^{2}$ ) e Santos $\mathrm{H}$ tem 53 apartamentos (35 de um dormitório com $30 \mathrm{~m}^{2}$ e 18 de dois dormitórios com $39 \mathrm{~m}^{2}$ ) (CDHU, 2012). A tabela 2 apresenta os empreendimentos realizados pela CDHU em cada município da Baixada Santista.

50 O projeto do edifício Santos I inclui o restauro das fachadas originais dos quatro lotes com frente para a Rua São Francisco, apesar de os terrenos não estarem incluídos nos níveis de proteção do Alegra Centro e do alto nível de deterioração das próprias fachadas, que mantém poucos dos elementos originais e que deverão ser praticamente reconstruídas para apresentar os aspectos originais. O interior dos lotes está completamente destruído, restando algumas ruínas das construções originais. O projeto prevê 54 apartamentos de um dormitório e 27 apartamentos de dois dormitórios com respectivamente $34 \mathrm{~m}^{2}$ e $50 \mathrm{~m}^{2}$. 
Figura 31: Conjunto Santos F da CDHU, Santos-SP.

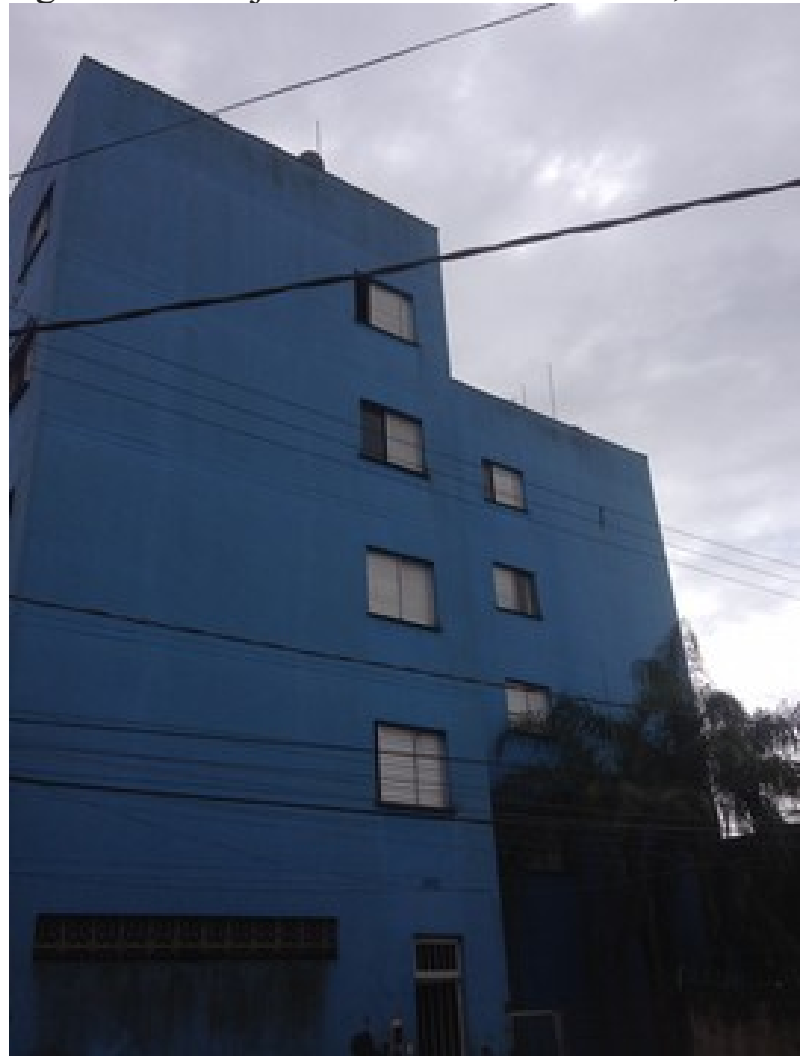

Fonte: Bruna G. Eskinazi - março de 2018.

Figura 32: Fachada do terreno do Santos I, Santos-SP.

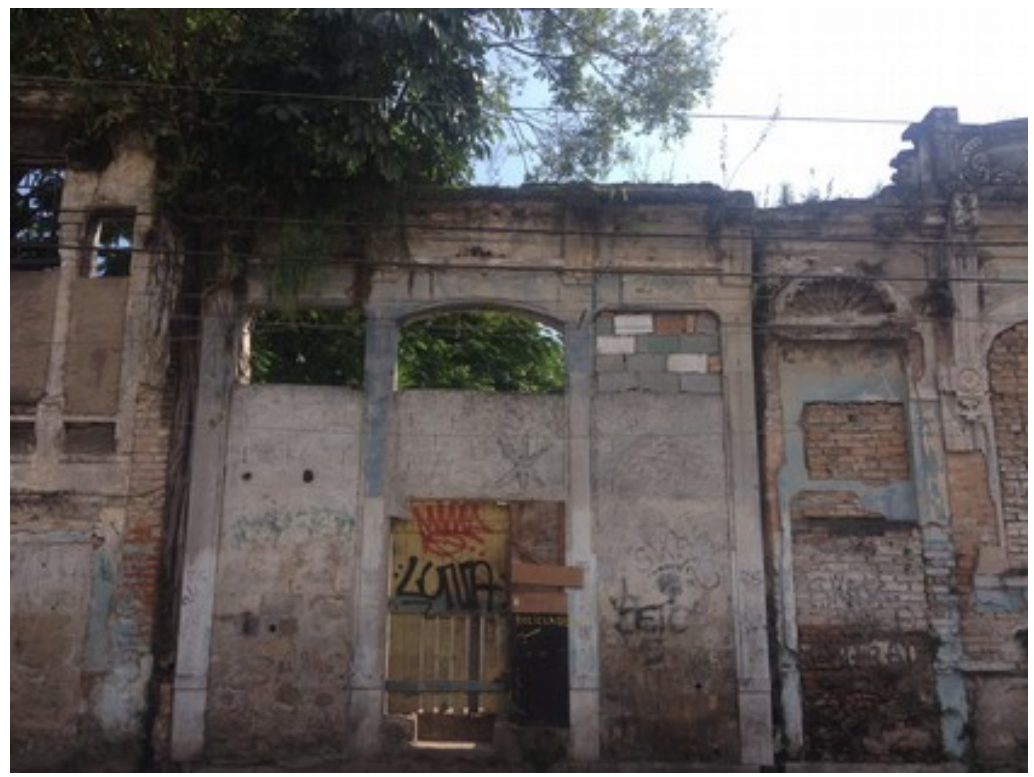

Fonte: Bruna G. Eskinazi - março de 2018.

As entrevistas com os membros da ACC revelam que um grande problema no cadastro da demanda para ocupar os condomínios da CDHU é a mudança dos moradores dos cortiços, que vão de um cortiço para outro, às vezes saindo da área de cadastramento. A ACC faz um esforço junto aos técnicos para que incluam as pessoas que recentemente se mudaram 
(principalmente nos casos das vagas para deficientes).

Além disso, foram concedidas pela CDHU 55 cartas de crédito para aquisição de imóveis em Santos. Os dados do bairro onde se localizam estes imóveis não foram disponibilizados.

Tabela 2: Unidades Habitacionais produzidas pela CDHU na Baixada Santista

\begin{tabular}{l|r|r|r|r|r|r|}
\hline \multicolumn{5}{|c|}{ Unidades Habitacionais financiadas pela CDHU nos municípios da RMBS } \\
\hline & Bertioga & Cubatão & Guarujá & Itanhaém & Mongaguá \\
\hline População* & 47.645 & 118.720 & 290.752 & 87.057 & 46.293 \\
\hline UHS $^{\star \star}$ & 1.728 & 4.555 & 3.977 & 2.101 & 674 \\
\hline & Peruíbe & Praia Grande & Santos & São Vicente & Total \\
\hline População* & 59.773 & 262.051 & 419.400 & 332.445 & $\mathbf{1 . 6 6 4 . 1 3 6}$ \\
\hline UHS $^{\star \star}$ & 822 & 742 & 2.365 & 3.166 & $\mathbf{2 0 . 1 3 0}$ \\
\hline
\end{tabular}

*Censo de 2010 do IBGE; **UHs construídas, lotes urbanizados e cartas de crédito, não inclui aluguel social.

Fonte: CDHU, organização nossa.

No âmbito do governo federal, foi criado o Programa Crédito Solidário ${ }^{51}$ (PCS), desenvolvido no primeiro governo Lula, em 2004, no contexto da criação do Ministério das Cidades. Um dos diferenciais desse programa é a possibilidade de realizar empreendimentos habitacionais por meio da autogestão. Isso colocou novos desafios aos movimentos sociais, que não estavam habituados à gestão de recursos financeiros e à administração de construções. Criou também uma cisão nos movimentos sociais: de um lado, aqueles que têm a capacidade de organização para gerir um empreendimento e, de outro, os que ainda têm uma organização muito incipiente, não podendo aglutinar suas bases e realizar este esforço.

O programa passou por alterações após a sua criação, por demanda dos movimentos sociais, para melhor se enquadrar nas possibilidades das famílias a que era dirigido. Os técnicos da Caixa Econômica Federal relatam que os empreendimentos mais bem-sucedidos, com menos atrasos e imprevistos, são aqueles em que os movimentos sociais estão bem ativos na gestão da obra e têm uma boa relação com a assessoria técnica. O PCS também previa o financiamento da assistência técnica, condicionado à aprovação da Caixa.

Uma das maiores dificuldades para os empreendimentos é a compra dos terrenos, competir pelos terrenos com as construtoras, que têm maior disponibilidade de recursos. Assim, frequentemente conseguiam somente os terrenos mais afastados dos centros. Entre 2005 e 2011, o PCS contratou 20.170 unidades habitacionais em todo o país.

Em 2009, o governo federal criou o programa Minha Casa Minha Vida (MCMV), que abrange diferentes faixas de renda e tinha a bandeira da construção de 1 milhão de unidades

51 Tendo como base a linha de financiamento da Carta de Crédito Associativa existente no governo de Fernando Henrique Cardoso. 
habitacionais - é o primeiro programa desde o BNH a tecer uma política nacional estruturada para a habitação social. Tal objetivo de 1 milhão de UHs foi atingido no final de 2010. Durante 2009, diversos movimentos de moradia reivindicaram que parcela dessas moradias fosse construída a partir de princípios da autogestão. Após negociações com o governo federal, essa demanda foi aceita, com a instituição do Minha Casa Minha Vida - Entidades. Foram destinados R $\$ 500$ milhões $^{52}$ do Fundo de Desenvolvimento Social (FDS) para os projetos do MCMV - Entidades, que foi elaborado baseado nas regras do PCS e do MCMV.

O Minha Casa Minha Vida funciona de forma diferente do PCS, que concedia financiamentos do valor total do imóvel, sem juros, a serem pagos em até 20 anos. O MCMV subsidia grande parte do valor do imóvel, entre $70 \%$ e $90 \%$, e o financiamento corresponde a $10 \%$ da renda familiar por 10 anos.

Uma das grandes críticas a este programa é a ausência de uma política fundiária que o acompanhe; para Volochko isso significa uma privatização da política urbana brasileira. $\mathrm{Na}$ sua formulação, o Estado não tem nenhum papel na seleção dos terrenos nos quais os empreendimentos serão realizados, assim, como o valor da unidade habitacional é relativamente baixo (até $\mathrm{R} \$ 65 \mathrm{mil}^{53}$ ), os terrenos escolhidos pelas construtoras estão frequentemente nas periferias, mantendo o padrão de segregação socioespacial das cidades brasileiras. Como aponta Volochko:

Através do Programa MCMV, o Estado viabiliza a reprodução imobiliária e financeira, facilitando a valorização e produção de fragmentos espaciais de áreas metropolitanas periféricas e assegurando a continuidade das estratégias privadas. A condição de pobreza e em parte de deficit habitacional é então amarrada pelo Estado à acumulação capitalista, que fica assim cada vez mais encarregada da produção da urbanização. Com o Programa MCMV, o Estado canaliza os recursos públicos para aquela produção/acumulação capitalista ocupada com a satisfação de parte das necessidades da reprodução da força de trabalho: a moradia, mas sobretudo para reproduzir os capitais presentes na sua realização como mercadoria (VOLOCHKO, 2015, p. 113).

$\mathrm{O}$ autor elenca o MCMV como um dos cinco fatores que possibilitaram a grande expansão do setor imobiliário entre 2005 e 2012. Os demais são: abertura do capital em bolsa de valores das principais incorporadoras; inflação estável, taxa de juros reduzida e queda do desemprego; flexibilização e ampliação da concessão de crédito imobiliário e alteração na legislação desse financiamento, com a alienação fiduciária do imóvel.

52 US\$ 213.949.500,00. Valor convertido segundo taxa de câmbio de 01 jan. 2009. (R\$ 828.492.750,00 em março de 2018).

53 US\$ 27.813,44. Valor convertido segundo taxa de câmbio de 01 jan. 2009. (R\$ 107.704,06 em março de 2018). 
Em 2009 foram feitas algumas alterações no MCMV - Entidades para melhorar as possibilidades de compra de terrenos. Com isso, a contratação passa a ser feita em duas etapas: na primeira são liberados os recursos para aquisição do terreno, projeto e topografia; após a entrega da documentação e de todos os estudos de viabilidade do empreendimento, na segunda etapa liberam-se os recursos para a construção das UHs.

Uma importante diferença entre o financiamento individual do MCMV e o do MCMV Entidades é a alienação fiduciária. No financiamento individual, o título de propriedade do apartamento ou da casa somente é entregue após a quitação das parcelas; enquanto isso ele permanece no nome da construtora. Quando o empreendimento é feito via uma associação ou movimento social, no MCMV - Entidades, o título de propriedade tanto do terreno quanto dos imóveis permanece no nome da associação ou do movimento até a quitação da dívida, quando passa a ser propriedade das famílias. Esse dispositivo protege as famílias que por algum motivo tenham dificuldade de pagar as parcelas por algum período.

Rizek (2017) aponta que quase todos os empreendimentos do MCMV - Entidades estão localizados em bairros periféricos; como o valor do terreno está embutido no valor de cada unidade habitacional, as entidades buscam sempre os terrenos mais baratos, consequentemente os mais distantes, em um mercado já aquecido pelo próprio programa habitacional. Até mesmo movimentos de moradia do centro de São Paulo, que ocupavam prédios abandonados, estão realizando empreendimentos do MCMV - Entidades no extremo leste da cidade. A modalidade tinha como meta totalizar 3\% de todos os empreendimentos do MCMV. No entanto, em 2015 representava 0,25\% dos recursos, $0,83 \%$ das UHs contratadas, mas apenas 0,36\% das UHs concluídas e 0,18\% das entregues (RIZEK, 2017).

Existem alguns empreendimentos do MCMV - Entidades no centro de São Paulo, mas estes não foram viabilizados com a compra de terrenos, e sim com a doação de imóveis públicos. Dessa forma, o chamado "retrofit" desses imóveis, ou seja, a sua readaptação para uso residencial, conta com um orçamento relativamente maior, pois os custos de aquisição do terreno e construção da estrutura do imóvel são economizados. Um imóvel visitado na Avenida Ipiranga, já finalizado, prestes a ser entregue às famílias, possuía um acabamento muito superior ao da maioria dos imóveis do MCMV, seja na modalidade construtoras, seja na de entidades.

Segundo a pesquisa realizada por Naime (2012), os empreendimentos com maior sucesso e menos atrasos e imprevistos são aqueles em que o movimento social acompanha a obra de 
perto, não delegando tudo para a assessoria técnica. Ainda que seja extremamente complexo e trabalhoso o papel de organizar e cadastrar beneficiários, buscar o terreno, realizar estudos de viabilidade, licenciamento e orçamentos, etapas que exigem conhecimentos e experiências que a maioria dos movimentos não têm.

A fase de elaboração de projetos, tanto no PCS quanto no MCMV - Entidades, é bastante difícil para as associações que não têm terrenos. Segundo a assessoria técnica Peabiru, ${ }^{54}$ essa fase inclui a procura de terrenos, o acordo de compra e venda, a elaboração de projeto e a aprovação pelos órgãos municipais e pela Caixa; às vezes o acordo de compra e venda acaba sendo desfeito e a associação e a assessoria perdem todo esse esforço feito. Existiam casos em que as assessorias recebiam o valor alguns anos depois da elaboração do primeiro projeto, pois todas as etapas de regularização do empreendimento são demoradas. Há também uma perda financeira para as associações que têm que fazer laudos ambientais ou de ruído para aprovação de seu empreendimento, pois um laudo ambiental custa por volta de R\$70 mil e, se o projeto não for aprovado ou o proprietário romper o acordo de compra e venda, esse valor é perdido.

As assessorias recebem, com relação ao projeto arquitetônico, 3\% do valor da obra em empreendimentos de até $100 \mathrm{UHs}, 2 \%$ em empreendimentos de 100 a 200 UHs e $1,5 \%$ em empreendimentos com mais de 200 UHs. Em projetos pequenos, de $50 \mathrm{UHs}$, o valor pago pela Caixa para a elaboração do projeto não é suficiente e as famílias precisam complementálo.

As assessorias técnicas também recebem uma quantia pelo trabalho social (R\$ 150,00 por família no PCS e R\$250,00 por família no MCMV-E I, valor que depois, nos MCMV-E II e III, passou a ser de $2 \%$ do valor da obra, um aumento significativo).

Trabalho social é esse trabalho com as famílias, de organização, organização das assembleias, das comissões que vão fazer acompanhamento de obra e outras coisas. Porque a assessoria técnica [...] tem esse trabalho que é interdisciplinar, tem os arquitetos, os engenheiros, fazem o projeto e tal. E a gente também desenvolve o trabalho social todo ou parte dele, depende um pouco da associação, como é a relação da associação com as famílias; provavelmente no caso da ACC, por exemplo, seria um trabalho compartilhado, provavelmente a gente entraria com alguma parte e eles fazendo outra parte de mobilização, que é do movimento, que é outra coisa

54 A Assessoria Técnica Peabiru foi criada em 1993 por um grupo de profissionais (advogados, engenheiros, arquitetos, sociólogo e psicólogo) que tinha atuado com movimentos populares no final da década de 1980, e trabalha com projetos de habitação de interesse social em São Paulo. A Peabiru realizou projetos ligados à gestão de Luiza Erundina (PT) na Prefeitura de São Paulo (com mutirão e autogestão), ao Programa de Arrendamento Residencial e, posteriormente, ao PCS e ao MCMV - Entidades. 
(depoimento ${ }^{55}$ de Maria Rita Horigoshi, arquiteta da Peabiru - maio de 2016).

É um trabalho que vai desde o levantamento da demanda até o acompanhamento da pósocupação do imóvel. Segundo o site da União Nacional por Moradia Popular consiste nas seguintes ações: “1) informações sobre o programa e o projeto em desenvolvimento; 2) apoio à organização e mobilização comunitária; 3) educação ambiental, sanitária, patrimonial para a cidadania e 4) geração de trabalho e renda e/ou capacitação profissional." (UNIÃO NACIONAL POR MORADIA POPULAR, 2009).

Em Santos, foram construídas pelo MCMV 817 unidades habitacionais (até dezembro de 2014), sendo $80 \%$ destinadas à faixa de renda 3: famílias com renda mensal entre R $\$ 3.275,00$ e R \$ 5.000,00. O restante foi para a faixa de renda 2: famílias com renda mensal entre R\$ 1.600,00 e R\$3.275,00. O único projeto do MCMV para a faixa de renda 1 (famílias com renda mensal até $\mathrm{R} \$ 1.600,00)$ em Santos é o condomínio da $\mathrm{ACC}$, que ainda não está finalizado. Na Baixada Santista, o programa foi responsável pela construção de 8.039 unidades habitacionais, com $68 \%$ para a faixa de renda 1 (um grande conjunto em Bertioga, dividido em 4 empreendimentos do MCMV-E, ainda não foi finalizado). Os empreendimentos para a faixa 1 do MCMV na Baixada Santista estão organizados na tabela 3, sendo que as cidades de Cubatão e Guarujá não têm nenhum empreendimento do programa e Mongaguá conta com um empreendimento para a faixa 2:

Tabela 3: Empreendimentos para a faixa de renda 1 do MCMV na Baixada Santista

\begin{tabular}{|l|r|r|r|r|}
\hline \multicolumn{5}{|c|}{ Empreendimentos do Minha Casa Minha Vida na Baixada Santista } \\
\hline Município & Empreendimentos & UHs & \multicolumn{1}{|c|}{ Valor em R\$ } & Modalidade \\
\hline Bertioga & 4 & 1.200 & $9.681 .857,60$ entidades \\
\hline Itanhaém & 33 & 2.604 & $167.213 .779,27$ & construtora \\
\hline Peruíbe & 6 & 528 & $30.754 .998,61$ construtora \\
\hline Praia Grande & 2 & 207 & $10.920 .834,80$ construtora \\
\hline Santos & 1 & 68 & $4.143 .376,65$ entidades \\
\hline São Vicente & 2 & 883 & $49.943 .295,89$ construtora \\
\hline Total & $\mathbf{4 8}$ & $\mathbf{5 . 4 9 0}$ & $\mathbf{2 7 2 . 6 5 8 . 1 4 2 , 8 2}$ \\
\hline
\end{tabular}

Fonte: Caixa Econômica Federal, organização nossa.

Quanto aos programas municipais de moradia, além dos conjuntos residenciais da Cohab-ST, há um programa de locação social voltado para a população idosa que vive com até um salário-mínimo, no qual a Prefeitura subsidia integral ou parcialmente o aluguel dessas pessoas. A chamada "República de Idosos" começou em 1996, com uma casa de 7 quartos e 14 moradores, selecionados por meio de um cadastro da Cohab-ST que elegeu idosos de 55 Todos os depoimentos foram reproduzidos conforme as gravações, mantendo as marcas da oralidade. 
menor renda que moravam em cortiços e não tinham uma família (SIQUEIRA, 1996; BRAGA, 2004). Atualmente, existem três casas com 29 moradores. Neste programa de locação social, os moradores pagam aluguel, contas de água e luz totalizando $\mathrm{R} \$ 160,00 .{ }^{56} \mathrm{O}$ projeto foi utilizado como modelo para políticas públicas no bairro do Pari, em São Paulo, e em quatro cidades da Paraíba (MENDES, HERMSDORF; OLIVEIRA, 2017).

Figura 33: República de Idosos, bairro Encruzilhada, Santos-SP.

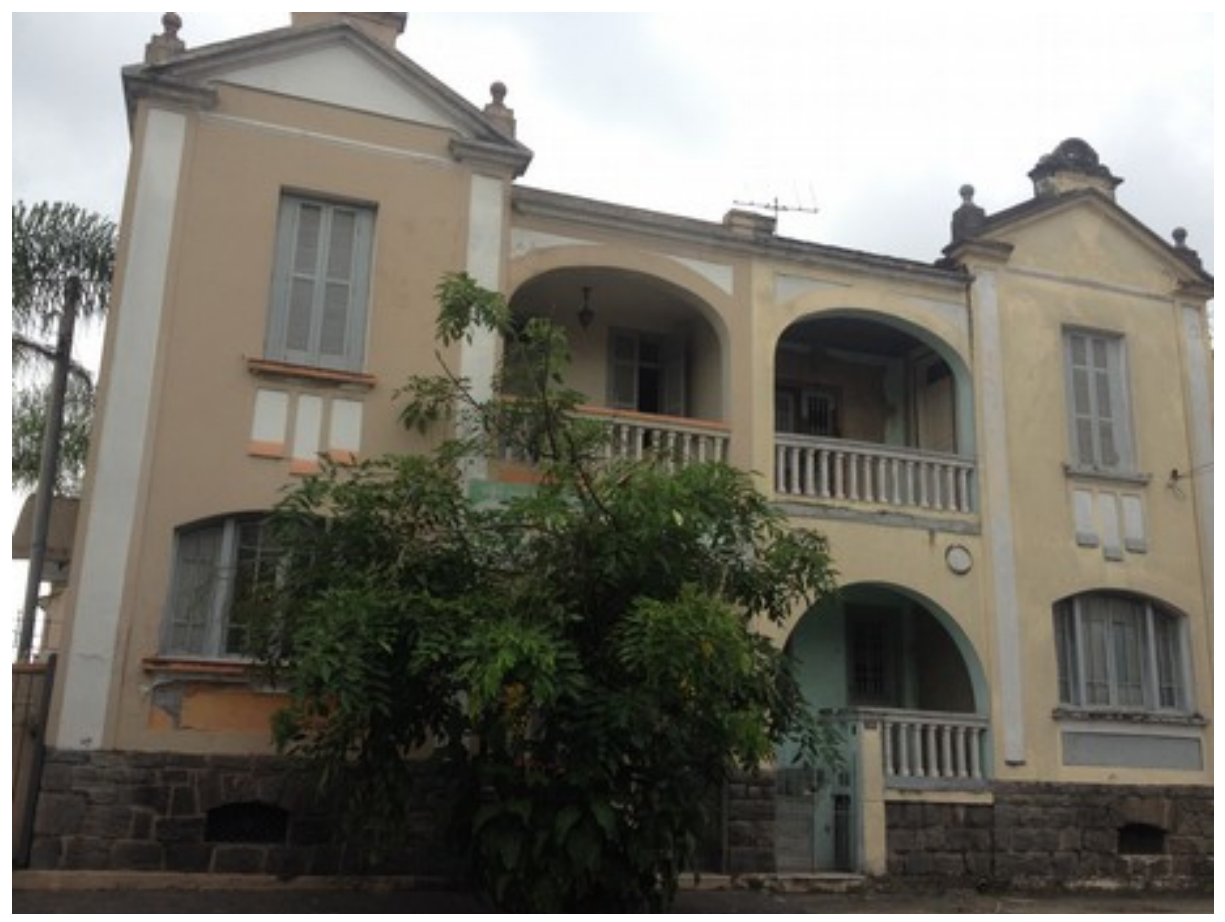

Fonte: Bruna G. Eskinazi - fevereiro de 2018.

Os demais programas de aluguel social da Prefeitura de Santos são de caráter emergencial, quando há remoção de casas em área de risco, incêndios em favelas ou outros acidentes. Não há uma política de aluguel social de longo prazo além da "República de Idosos".

O Programa Alegra Centro Habitação já foi apresentado no capítulo anterior, mas teceremos aqui algumas considerações, levando em conta o panorama de políticas públicas de habitação em Santos. O programa somente foi desenvolvido pela Prefeitura por pressão dos movimentos por moradia, tendo em vista seu descontentamento com o Alegra Centro, que não problematizava a questão do patrimônio histórico habitado em condições precárias. Assim, sete anos depois do início do Alegra Centro, a Prefeitura sancionou a Lei Complementar $\mathrm{n}^{\circ}$ 688, que regulamenta as normas de salubridade e dispõe a criação do escritório técnico para supervisionar e fiscalizar as obras. No entanto, a iniciativa não foi bem-sucedida, pois muitos proprietários, vendo-se ameaçados com multas em caso de não cumprimento das regras

56 Valores relativos ao mês de julho de 2017. 
estabelecidas, preferiram esvaziar seus imóveis. Como o programa foi interrompido e a legislação se encontra atualmente em revisão na Câmara Municipal, não é possível tecer previsões de como será realizada essa política pública no futuro.

Cabe somente pensar em possibilidades, como a desapropriação de alguns imóveis e sua reversão para locação social após sua reabilitação. A sobreposição entre a área de proteção cultural 2 e a Zeis 3 poderia facilitar esse processo, especialmente considerando que a legislação de Zeis afirma ser um dos seus objetivos evitar processos de expulsão dos moradores, além de reformar e renovar o conjunto arquitetônico existente nesse perímetro.

Existe também um mecanismo legal para pressionar os proprietários de cortiços a reformarem seus imóveis, que não foi previsto na lei do Alegra Centro Habitação. A Lei Federal n ${ }^{\circ}$ 8.245, de 18 de outubro de 1991, que prevê sobre locação de imóveis urbanos, dispõe:

Art. 24. Nos imóveis utilizados como habitação coletiva multifamiliar, os locatários ou sublocatários poderão depositar judicialmente o aluguel e encargos se a construção for considerada em condições precárias pelo Poder Público.

$1^{\circ} \mathrm{O}$ levantamento dos depósitos somente será deferido com a comunicação, pela autoridade pública, da regularização do imóvel. $2^{\circ}$ Os locatários ou sublocatários que deixarem o imóvel estarão desobrigados do aluguel durante a execução das obras necessárias à regularização.

$3^{\circ}$ Os depósitos efetuados em juízo pelos locatários e sublocatários poderão ser levantados, mediante ordem judicial, para realização das obras ou serviços necessários à regularização do imóvel.

Dessa forma, o poder público municipal poderia intervir diretamente nos imóveis e utilizar até mesmo os recursos provenientes dos aluguéis para realizar as reformas.

O Brasil é signatário de vários tratados internacionais que determinam como função do Estado garantir o direito à moradia: Declaração sobre o Direito ao Desenvolvimento da ONU (1986), Convenção sobre o Direito das Crianças da ONU (1989), Declaração de Istambul sobre Assentamentos Humanos (1996). Este direito também está previsto na Constituição Federal e no Estatuto da Cidade (Lei 10.257, de 10 de julho de 2001): “A Constituição Federal de 1988, além de incluir o direito à moradia como um direito social, dispõe sobre a obrigação dos entes federativos na aplicação das políticas públicas para efetivação do direito à moradia" (PAGANI, 2009, p. 157). E apesar de a Constituição Federal determinar que o direito à propriedade fundiária está condicionado à sua função social, e de o Estatuto da Cidade determinar que o poder público municipal, a partir de sua política urbana, é o responsável por aplicar IPTU progressivo no tempo, e até mesmo a expropriação do imóvel para garantir o cumprimento da sua função social, raras são as vezes em que esses mecanismos são utilizados 
para garantir às populações mais vulneráveis o direito à moradia. Existe uma quantidade enorme de imóveis não utilizados ou subutilizados nas cidades brasileiras. ${ }^{57}$ No entanto, são poucas as aplicações de IPTU progressivo no tempo, ou a adoção de outras medidas para garantir a função social do estoque imobiliário já existente. Pelo contrário, são vistas na mídia inúmeras desapropriações de imóveis ocupados por movimentos de moradia, sendo que muitos dos proprietários não pagam regularmente seus impostos. Concordamos com Pagani:

o deficit habitacional, tanto no aspecto quantitativo como qualitativo, não é resultado da falta física de imóveis no meio urbano, mas sim da tímida aplicação de políticas públicas urbanas pelo Estado objetivando fiscalizar e implementar as recentes leis existentes que contemplam a regularização fundiária e, com efeito, o direito à moradia (PAGANI, 2009, p. 199).

$\mathrm{Na}$ prática, o direito à propriedade é superior ao direito à moradia no Brasil, e não existem ações expressivas do poder público para garantir a função social da propriedade e, consequentemente, o direito dos não-proprietários em ter acesso a uma moradia digna. Não existe também uma regulação direta dos preços de aluguéis, e nos períodos de crise econômica, como o atual, muitas famílias afetadas pelo desemprego ou com poucos rendimentos provenientes de trabalhos informais são incapazes de continuar pagando seus aluguéis. Continua a contradição que evidencia a primazia do direito à propriedade: tanta casa sem gente, tanta gente sem casa.

57 Ação da Prefeitura de São Paulo em 2014 identificou 613 imóveis edificados nas áreas centrais que não eram utilizados (COSTA, 2017). 


\section{Capítulo 3: Direito à Memória e Políticas de Preservação do Patrimônio em Santos-SP}

Glória a todas as lutas inglórias

Que através da nossa história não esquecemos jamais

Salve o navegante negro

Que tem por monumento as pedras pisadas do cais

João Bosco e Aldir Blanc

Para entender os recentes projetos de preservação do patrimônio em Santos, como os Corredores de Proteção Cultural e o Alegra Centro, é importante fazer uma retrospectiva das políticas de preservação do patrimônio na cidade - questão que nem sempre foi uma preocupação da administração pública e da população santista. Antes, no entanto, algumas questões teóricas devem ser abordadas, na tentativa de responder: O que preservar? Por que preservar? Para que preservar? Para quem preservar?

Riegl, no final do século XIX, investigou a caracterização dos monumentos e definiu monumento histórico como "toda obra de arte agregada a seu respectivo valor histórico. Era pois, diferente do simples monumento (chamado intencionado), cujas funções de transmissão e rememoração já eram dadas em sua gênese, não necessitando de um posterior reconhecimento de valor" (ARAÚJO, 2008, p. 32).

$\mathrm{O}$ autor dividiu os monumentos em três tipos. $\mathrm{O}$ primeiro engloba aqueles que têm um valor histórico, rememoram um determinado momento histórico e têm valor documental, sendo utilizados para a manutenção da memória do contexto histórico em que foram criados. São construções que passaram a ter um valor rememorativo posterior à sua construção, não foram planejados com esse fim. Já os "monumentos de intencionalidade" foram construídos com o objetivo de recordar determinado fato ou período; são exemplos desse tipo as placas que marcam que em determinado lugar se passou um fato histórico, ou as estátuas que celebram episódios relevantes da historiografia oficial. Um terceiro tipo é o "monumento de antiguidade", frequentemente em ruínas, cujo valor é, em síntese, o de seu tempo vivido e de sua capacidade de permanência.

Todorov, em "Los abusos de la memoria", aponta os perigos da perda da memória e do trunfo estratégico que é, principalmente para os regimes totalitários, o controle e a manipulação da memória. Também destaca a importância das lições que a história pode nos fornecer.

Abro essa lembrança à analogia e à generalização, construo um exemplo e 
extraio uma lição. O passado se converte, portanto, em princípio de ação para o presente. [...] O uso exemplar [...] permite utilizar o passado com vistas ao presente, aproveitar as lições das injustiças sofridas para lutar contra as que se produzem hoje em dia e se separar do eu para ir em direção ao outro (TODOROV, 2000, p. 31-32, tradução nossa). ${ }^{58}$

Ainda que o autor não fale diretamente da preservação do patrimônio arquitetônico, é difícil pensar na preservação da memória sem a preservação de seus suportes espaciais, sejam estes monumentos intencionados ou monumentos históricos, casas, praças, igrejas, estátuas ou placas. Ainda que seja de fundamental importância a conservação de arquivos e documentos, ${ }^{59}$ a preservação das edificações alcança um público mais amplo; uma cidade com um centro histórico preservado, por exemplo, permeia o cotidiano de seus cidadãos de referências ao passado. "Destruindo os suportes materiais da memória, a sociedade capitalista bloqueou os caminhos da lembrança, arrancou seus marcos e apagou seus rastros" (CHAUÍ, 1979, p. XIX). Claro que a preservação por si só da edificação não significa a manutenção da memória, mas a utilização do edifício preservado tem a capacidade potencial de manter a memória viva.

Para Arantes, a preservação, que advém da intenção de manter laços com o passado, é uma interpretação desse passado e deve ser pensada "como trabalho transformador e seletivo de reconstrução e destruição do passado, que é realizado no presente e nos termos do presente" (ARANTES, 1984, p. 9). Estas interpretações do passado são objeto de disputa entre diferentes grupos sociais que buscam se apropriar simbolicamente desses espaços.

A interpretação de Bolle sobre a preservação caminha no mesmo sentido de Arantes, ao afirmar que "preservar pressupõe um projeto de construção do presente" (BOLLE, 1984, p. 13). Ele destaca a disputa de construção de sentidos para a preservação do patrimônio, pois construir uma determinada narrativa do passado implica determinados poderes presentes.

Um exemplo utilizado por Bolle, e também por Todorov, é o Holocausto: conhecer e manter viva a memória deste período histórico é uma forma de resistência à xenofobia, ao racismo, etc. Por outro lado, a negação ${ }^{60}$ ou o esquecimento de tais crimes enfraquece a luta das vítimas

58 Abro ese recuerdo a la analogía y a la generalización, construyo un exemplum y extraigo una lección. El pasado se convierte por tanto em principio de acción para el presente. (...) El uso ejemplar, por el contrario permite utilizar el pasado com vistas al presente, aprovechar las lecciones de las injusticias sufridas para luchar contra las que se producen hoy día, y separarse del yo para ir hacia el outro. (TODOROV, 2000, p. 31-32).

59 A historiadora Betralda Lopes (1975) aponta na introdução de seu trabalho a dificuldade que teve em sua pesquisa por causa da precariedade de muitos arquivos. O conteúdo de um deles, por exemplo, estava prestes a ser vendido como papel velho pela falta de recursos para sua manutenção.

60 A negação do Holocausto por David Irving tornou-se um caso judicial na Inglaterra, na década de 1990, e também outros grupos antissemitas que mantêm esse discurso. 
e de seus descendentes, ao mesmo tempo em que pode fortalecer grupos neonazistas. Assim, podemos entender a disputa pelo patrimônio como uma disputa pela narrativa histórica e, portanto, parte de uma disputa por poder.

Éclea Bosi, em seu estudo sobre a memória social de velhos, apresenta distintos aspectos da memória: 1) a memória-hábito, que é a memória dos mecanismos motores; 2) sua dimensão individual, a transformação da lembrança com o passar do tempo, com a mudança de perspectiva daquele que recorda; 3) a socialização das crianças a partir das memórias dos adultos, e principalmente dos velhos; 4) sua dimensão coletiva, na medida em que os grupos e instituições (em primeira instância a linguagem) contribuem com a produção da memória e com suas interpretações.

Um dos aspectos mais instigantes do tema é o da construção social da memória. Quando um grupo trabalha intensamente em conjunto, há uma tendência de criar esquemas coerentes de narração e de interpretação dos fatos, verdadeiros "universos de discurso", "universos de significado", que dão ao material de base uma forma histórica própria, uma versão consagrada dos acontecimentos. O ponto de vista do grupo constrói e procura fixar a sua imagem para a História. Este é, como se pode supor, o momento áureo da ideologia com todos os seus estereótipos e mitos. No outro extremo, haveria uma ausência de elaboração grupal em torno de certos acontecimentos ou situações. A rigor, o efeito, nesse caso, seria o de esquecer tudo quanto não fosse "atualmente" significativo para o grupo de convívio da pessoa. É o que sucede às vezes: os fatos que não foram testemunhados "perdem-se", "omitem-se" porque não costumam ser objeto de conversa e de narração, a não ser excepcionalmente (BOSI, 1979, p. 27, grifo da autora).

Em Santos, assim como no Brasil de maneira geral, a preocupação com a preservação de marcos arquitetônicos é relativamente recente, das primeiras décadas do século XX. A preservação estava ligada à criação de uma identidade nacional para uma república bastante jovem, e grande parte dos imóveis protegidos santistas são do período colonial (do século XVI até 1822) ou do período do auge da economia cafeeira (entre 1870 e 1920). Podemos fazer uma leitura da questão patrimonial no Brasil, e em particular em Santos, a partir do conceito de "tradição inventada" de Hobsbawm, que nos permite compreender que a celebração de determinados capítulos da história da cidade reintroduz "o status no mundo do contrato social, o superior e o inferior num mundo de iguais perante a lei" (HOBSBAWM, 1997, p. 18). Portanto, não é qualquer história que é celebrada e não é qualquer patrimônio arquitetônico (com qualquer narrativa) que é estimulado a ser restaurado e preservado: “A história que se tornou parte do cabedal de conhecimento ou ideologia da nação, Estado ou movimento não corresponde ao que foi realmente conservado na memória popular, mas àquilo 
que foi selecionado, escrito, descrito, popularizado e institucionalizado por quem estava encarregado de fazê-lo" (HOBSBAWM, 1997, p. 21).

Chaú dialoga com Bosi e explicita a questão da memória política contida nos relatos presentes em seu trabalho:

Todavia, a memória não é oprimida apenas porque lhe foram roubados suportes materiais, nem só porque o velho foi reduzido à monotonia da repetição, mas também porque uma outra ação, mais daninha e sinistra, sufoca a lembrança: a história oficial celebrativa, cujo triunfalismo é a vitória do vencedor a pisotear a tradição dos vencidos. Um dos aspectos mais dolorosos de seu livro, Ecléa, aparece quando você nos mostra o que ocorre com a memória política. Após terem sido capazes de reconstruir e interpretar os acontecimentos de que foram participantes ou testemunhas, os recordadores (com exceção de D. Brites e de D. Lavínia) restauram os estereótipos oficiais, necessários à sobrevivência da ideologia da classe dominante. Dessa maneira, as lembranças pessoais e grupais são invadidas por outra "história", por uma outra memória que rouba das primeiras o sentido, a transparência e a verdade (CHAUÍ, 1979, p. XIX).

A história oficial celebrativa é transmitida nas escolas, mas também por meio dos monumentos históricos e pelos monumentos intencionados. Pode-se analisar as narrativas que são criadas com a valorização desse patrimônio, em particular com auxílio de uma reflexão de Benjamin, quando este indaga com quem o investigador historicista estabelece uma relação de empatia: "A resposta é inequívoca: com o vencedor. Ora, os que num momento dado dominam são os herdeiros de todos os que venceram antes. A empatia com o vencedor beneficia sempre, portanto, esses dominadores" (1996, p. 225). As narrativas da historiografia oficial e do patrimônio histórico (sobretudo o patrimônio arquitetônico) são narrativas dos vencedores. A célebre afirmação de Benjamin nos demonstra isso: "Nunca houve um monumento da cultura que não fosse também um monumento da barbárie. E, assim, como a cultura não é isenta de barbárie, não o é, tampouco, o processo de transmissão da cultura" (1996, p. 225).

Se a escolha do patrimônio a ser protegido faz parte de uma determinada narrativa histórica, como será a narrativa transmitida pela educação patrimonial? É possível subverter as escolhas políticas da proteção deste patrimônio? É possível realizar uma abordagem tratando esses monumentos de cultura como monumentos de barbárie? ${ }^{61}$

61 Algumas ações sobre monumentos intencionados tentam chamar a atenção para o seu aspecto de monumento de barbárie, como pichar de vermelho o Monumento às Bandeiras e a estátua de Borba Gato em São Paulo (ainda que os dois tenham concepções distintas, tratam do tema dos bandeirantes). 


\subsection{As políticas de preservação em Santos-SP}

Uma das primeiras pessoas a levantar a questão da conservação do patrimônio santista e discuti-la publicamente foi o pintor Benedito Calixto, que entendia que uma cidade moderna era o resultado de um processo de desenvolvimento, as formas antigas sendo um testemunho do percurso histórico daquele lugar. $\mathrm{O}$ pintor representava o pensamento corrente dos Institutos Históricos e Geográficos (IHG) do país, em particular os de São Paulo e de Santos, nos quais

sobressaía certa intenção comum que os identificava: criar uma história brasileira, ou melhor, dar um passado ao país, e generalizar histórias de certos grupos regionais influentes. Com efeito, os institutos cumpriram à risca o ditado que diz "para bem lembrar é preciso muito esquecer", melhor que tal atitude deliberada implicasse uma eleição rigorosa dos pares, para melhor delimitar o espaço dos excluídos. (SCHWARZ, 1993, p. 136)

Ou seja, lembrar de grandes fatos, dos grandes homens, e esquecer certas máculas da história, como a escravidão, ${ }^{62}$ as epidemias, a miséria, etc. Os IHGs contribuíram para a invenção das tradições brasileiras e para a seleção do que era digno de entrar na historiografia oficial, na história dos vencedores.

A segunda particularidade da figura de Calixto é a sua obra. O pintor recebeu diversas encomendas para retratar cenas de fatos marcantes da história do Brasil, em um momento em que a história oficial do país estava sendo formada. Meneses aponta que suas telas têm antes uma função de evocação e de celebração do que de conhecimento histórico. ${ }^{63}$

Muitas das telas de Calixto são de paisagens, cenas do porto, panorâmicas da cidade e do centro e de edifícios históricos que não existem mais, como a Capela da Graça (figura 34). Sua carreira de mais de 50 anos registra importantes mudanças pelas quais Santos passou na virada do século, com inúmeras demolições para modificar o traçado das ruas estreitas do centro.

A demolição da Casa do Conselho ocorreu em 1866; o prédio do século XVII foi sede do poder imperial em Santos em um período em que a exportação cafeeira se expandia, assim como crescia a importância do porto, e algumas modificações começavam a ser feitas na

62 É importante lembrar da queima dos arquivos da escravidão pelo então ministro da Fazenda, Rui Barbosa, durante o governo provisório de Marechal Deodoro. Ainda que haja argumentos favoráveis à atitude do ministro, pois seu objetivo era minar as demandas de indenizações dos ex-donos de escravos, tal ato provocou enorme perda de documentação histórica.

63 "O universo documentado por Calixto não é o do século XVI, mas sim o do seu tempo, a virada do século XIX. É nesta direção, pois, que sua obra conviria ser explorada e é no campo do imaginário tardooitocentista que seu valor documental é relevante" (MENESES, 1990, p. 45). 
cidade, que ainda mantinha seus traços de vilarejo colonial. O Outeiro de Santa Catarina, marco fundador da cidade, foi demolido em 1880 para transformar o Beco de Santa Catarina em rua, facilitando os deslocamentos. Na primeira década do século XX ocorreram mais demolições, paralelamente ao projeto urbanístico de Saturnino. A Igreja Jesus, Maria e José, do final do século XVIII, foi demolida em 1902, com a justificativa de que estava em péssimo estado de conservação. Derrubada em 1903, a Capela da Graça, de 1562, contrastava a sua simplicidade colonial com construções mais novas, como a Casa da Frontaria Azulejada, situada na mesma rua. Provavelmente a maior perda arquitetônica dentre as 14 igrejas e capelas demolidas a partir da metade do século XIX foi a da Igreja da Matriz (figura 35) inaugurada em 1746, era um exemplo de arte barroca e recebeu vários membros da família real. No início do século XX, talvez por descaso das últimas administrações, a igreja estava em péssimo estado de conservação e foi demolida em 1908, com a alegação de que estava sob risco de desabamento.

Figura 34: A Capela da Graça, tela de Benedito Calixto.

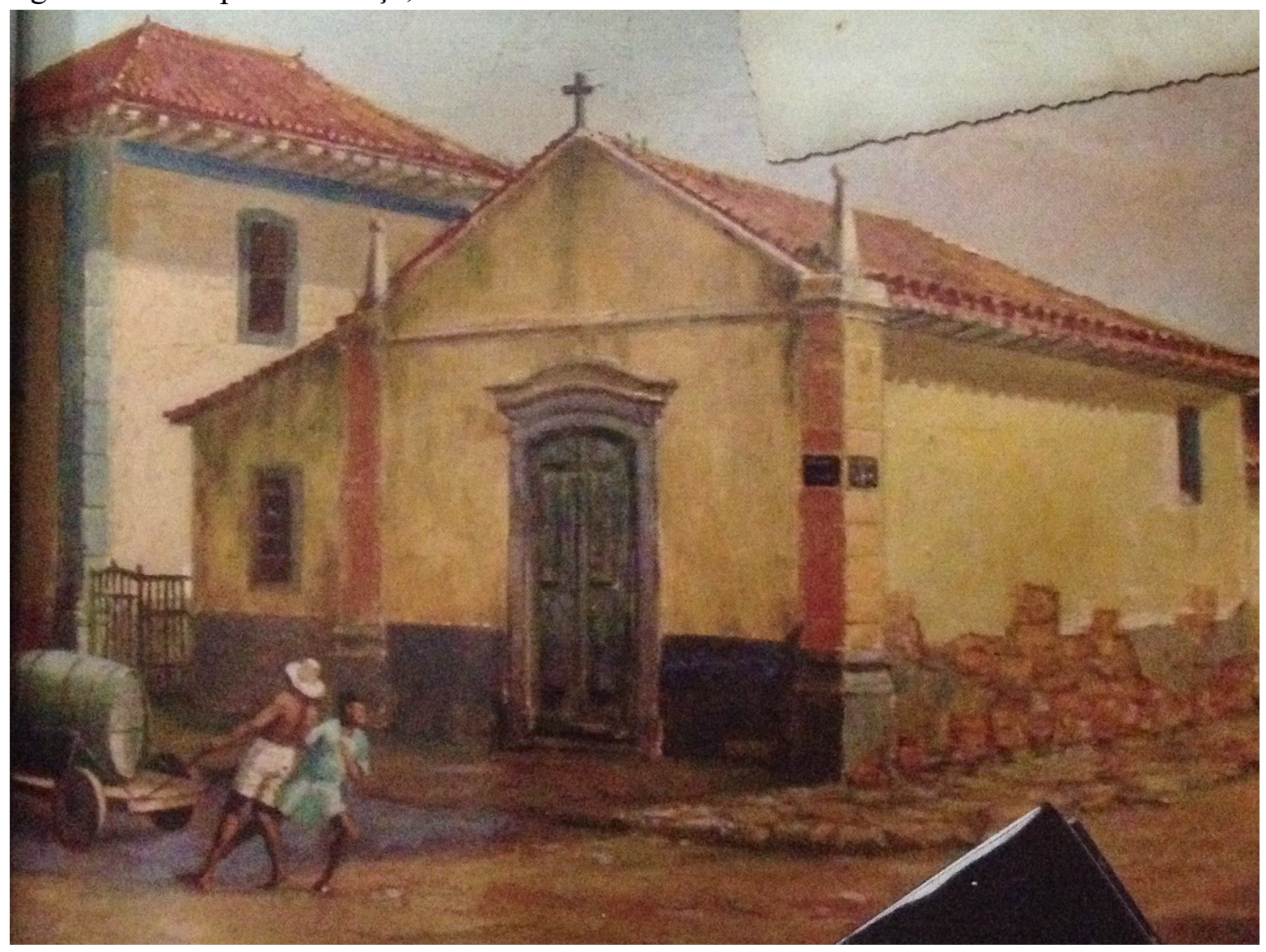

Fonte: Almanaque de Santos, 2011. 
Figura 35: Igreja da Matriz de Santos, tela de Benedito Calixto.

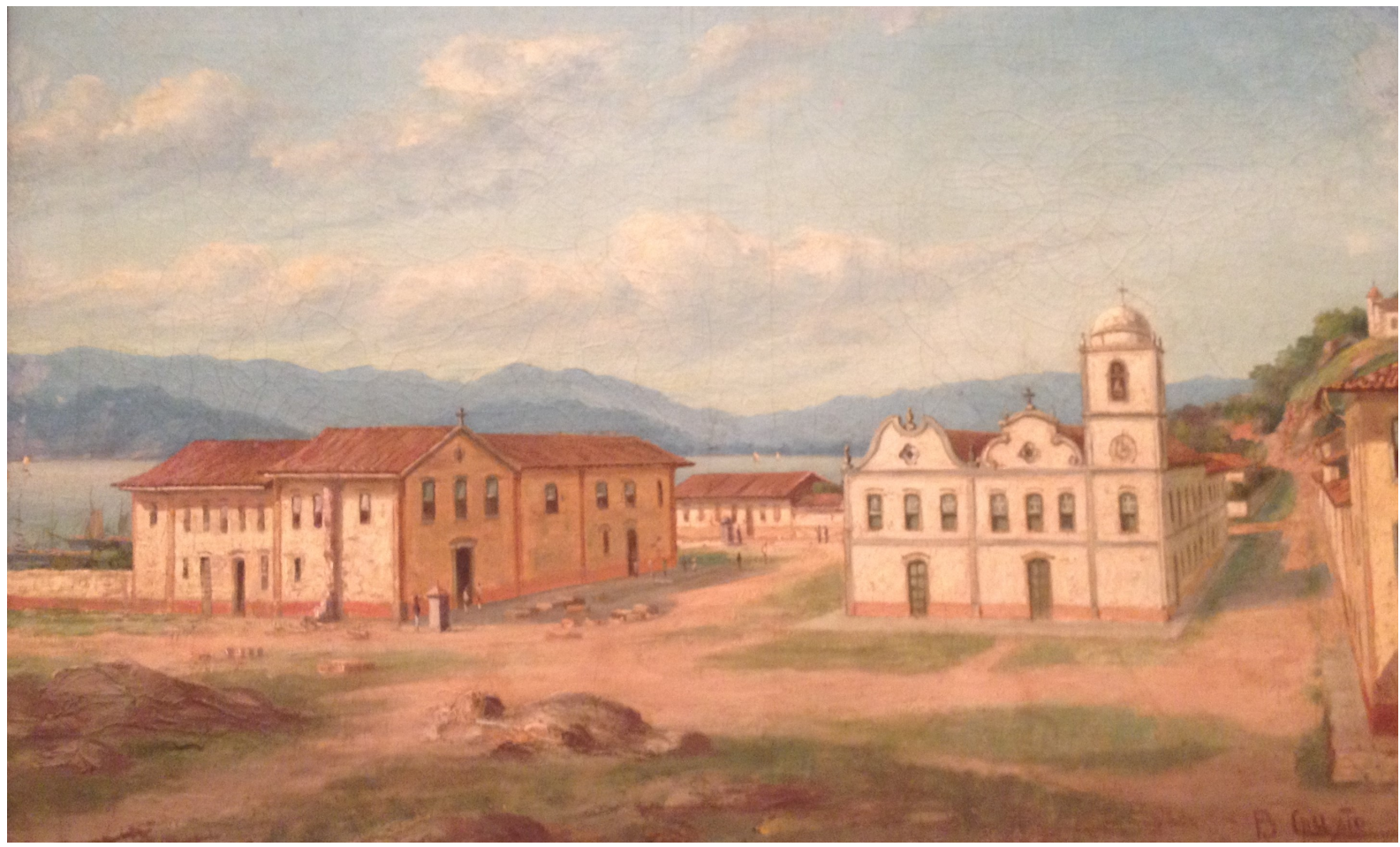

Fonte: Acervo da Pinacoteca Benedito Calixto.

A Igreja São Francisco de Paula, também do século XVIII, foi interditada após um desabamento no Monte Serrat em 1928, que soterrou parte da Santa Casa da Misericórdia. O poder público, temendo novos desabamentos, interditou as edificações ao sopé do morro, incluindo a igreja, que ficaram abandonadas. A igreja foi demolida mais de 20 anos depois.

A demolição dessas igrejas e capelas não pode ser vista isoladamente, ela faz parte de um conjunto de modificações na cidade de Santos, sendo a principal a reforma urbanística de Saturnino de Brito. As avenidas largas para circulação de automóveis e as novas construções de estilo eclético da elite local não dialogavam com construções coloniais e ruelas de paralelepípedos para pedestres. Em um período em que se clamava pelo moderno, eram poucos os que consideravam importante a preservação de imóveis com valor histórico.

A discussão do patrimônio só foi ampliada no Brasil com a criação do Serviço do Patrimônio Histórico e Artístico Nacional (Sphan, e posteriormente denominado Iphan) em nível federal, em 1937. Nas primeiras décadas do século XX, o IHG de Santos valorizava monumentos intencionados, como as estátuas de Brás Cubas, Bartolomeu de Gusmão e José Joaquim Xavier da Fonseca, o monumento a Gaffré e Guinle e o Panteão dos Andradas. Não se considerava a capacidade dos edifícios na transmissão da memória. Em 1922, no centenário da Independência, foi construído o monumento aos Andradas na Praça da Independência - um 
dos inúmeros ${ }^{64}$ exemplos de monumentos intencionados de Santos, adequados ao discurso de patriotismo e civismo dos IHGs. Somente em uma publicação de 1969 o IHG de Santos mencionou a importância dos edifícios históricos para a preservação da memória.

Segundo Lia Motta, com a criação do Sphan se iniciou o primeiro período no tratamento dos sítios históricos no Brasil, que se estendeu até 1970 e foi marcado pela seleção de edificações e sítios urbanos coloniais como a única referência identitária da nação. Não foram consideradas, por exemplo, edificações de arquitetura eclética, características da segunda metade do século XIX, entre outros estilos. Assim, os critérios para tombamento eram puramente estéticos, e não de qualquer estética, mas apenas a barroca. Com isso, os Estados que tiveram mais tombamentos foram Minas Gerais e Bahia, tão ricos na produção de uma arquitetura que 'representava a primeira expressão 'autenticamente' brasileira, o ‘abrasileiramento' das construções portuguesas” (MOTTA, 2000, p. 264).

Em Santos houve o tombamento de seis edificações entre a criação do Sphan e 1973:

- Casa do Trem Bélico, em 1940.

- Igreja da Ordem Terceira de Nossa Senhora do Carmo, em 1940.

- Mosteiro e Igreja de São Bento, em 1948.

- Casa de Câmara e Cadeia, em 1959.

- Engenho São Jorge dos Erasmos, em 1963.

- Casa da Frontaria Azulejada, em 1973.

Todas são construções coloniais no centro, ${ }^{65}$ com exceção do Engenho (que é também sítio arqueológico), que fica na zona noroeste e é provavelmente o engenho de açúcar mais antigo do Brasil, de 1534.

Os tombamentos, porém, não fomentaram uma discussão pública a respeito da preservação do patrimônio até meados dos anos 1960. Em 1961, para implantação de uma obra viária o prefeito de Santos solicitou o destombamento da Casa de Câmara e Cadeia, pedido este indeferido pelo Iphan. Araújo verificou, por meio de pesquisa em jornais da época, que a partir de 1970 começou uma discussão sobre o estado de conservação dos bens tombados, principalmente do Mosteiro de São Bento, pois ao ser tombado fora decidido que abrigaria o Museu de Arte Sacra, e até aquele momento nada tinha sido feito. Os artigos na imprensa

64 Existem vários monumentos intencionados nas praças do centro de Santos, mas a maioria destes se encontra nos Jardins da Orla, que tem monumentos a instituições, a personalidades importantes da cidade, aos imigrantes, etc.

65 Foi tombada em 1940, junto com a Casa do Trem Bélico, a Fortaleza de São Tiago, situada no antigo distrito de Bertioga, emancipado na década de 1990. 
apontavam que o tombamento por si só não era capaz de preservar o monumento, era necessária sua restauração.

Alguns anos depois um fato mudou completamente as discussões e opiniões sobre o patrimônio na cidade. Em 16 de julho de 1973 iniciou-se a demolição do Hotel Parque Balneário, na Avenida Ana Costa, no bairro Gonzaga. O hotel era um símbolo do luxo e das elites, e durante o verão santistas e turistas frequentavam seu restaurante e o cassino. A demolição ${ }^{66}$ foi uma surpresa para os santistas, que tinham notícias de que seria derrubado, mas não acreditavam nelas.

A partir daí começou uma preocupação com a conservação dos demais patrimônios de Santos. No ano seguinte, o primeiro pedido de tombamento originado na própria cidade foi enviado ao Conselho de Defesa do Patrimônio Histórico, Arqueológico, Artístico e Turístico (Condephaat), órgão estadual que fora criado em 1969 e até então só tombara bens na cidade em caráter ex-officio, ou seja, bens já tombados pelo Iphan. Foram solicitados os tombamentos do prédio da Bolsa do Café e do Casarão do Valongo, ${ }^{67}$ que, entre outras funções, abrigara a Prefeitura. Este primeiro pedido foi apoiado por políticos, dentre eles o então secretário estadual de Turismo, que anexou uma carta ao processo. O segundo pedido teve como interessada a professora de história Wilma Terezinha de Andrade, que foi importante figura na mobilização pela preservação do patrimônio da cidade, participando de palestras e recolhendo assinaturas em abaixo-assinados para anexar aos pedidos de tombamento. Na solicitação de tombamento do Casarão do Valongo foram anexadas cerca de 100 assinaturas, assim como a reclamação de que, apesar de o imóvel estar em processo de tombamento desde 1968 pelo Iphan, ele vinha sofrendo algumas descaracterizações, como mudança nos batentes e nas venezianas, retirada de azulejos originais, etc (ARAÚJO, 2008). A preocupação maior, de acordo com os registros da imprensa, dizia respeito à função que o imóvel teria após o tombamento. Havia um grande interesse em que nesses edifícios fossem instalados museus - que não existiam na cidade - para uso dos cidadãos e também para os turistas. Era do interesse de vários setores que houvesse alternativas às praias, para incentivar o turismo mesmo fora dos meses de verão ou quando os níveis de poluição das praias não permitissem o banho. Nesse sentido, foi assinado em 1971 por representantes de vários Estados e municípios, inclusive Santos, o Compromisso de Salvador, documento que

66 Araújo argumenta que o termo mais apropriado é desmonte do hotel, pois suas partes foram retiradas e vendidas.

67 Na década seguinte, 12 pedidos de tombamento foram feitos ao Condephaat. 
incentivava usos turísticos do patrimônio natural e cultural. Foram criadas outras opções de lazer na cidade, como roteiros histórico-culturais e festivais de inverno.

Essa maior preocupação da população santista com o patrimônio não foi um caso isolado no período. Segundo Motta, entre 1970 e 1990 87\% dos processos de tombamento do Iphan foram abertos por pedidos externos ao instituto, demonstrando a preocupação de várias comunidades organizadas em conservar seu patrimônio histórico. Com isso mudou também o entendimento do que era patrimônio, e construções de outros estilos, além do barroco, despertaram interesse de preservação nos cidadãos. Mas o principal motivo para os pedidos de tombamento era o valor estético e arquitetônico, ainda não eram incluídos exemplares da arquitetura vernacular.

A partir da década de 1980, os motivos do Iphan para definir tombamentos vão além das questões estéticas, mais precisamente com o tombamento de Laguna, em 1985. A cidade portuária em Santa Catarina inaugurou uma série de tombamentos que colocavam em primeiro plano a história processual, valorizando mais o conjunto das edificações do que monumentos isolados, pois somente enquanto conjunto se pode fazer uma leitura mais ampla do patrimônio enquanto documento. Os estudos de tombamento opõem-se à corrente historiográfica dos IHGs, pois não abordam a história dos grandes feitos e grandes homens, mas priorizam os processos históricos; desta forma, não é possível preservar uma ou duas casas para ter documentos da ocupação do território no sul do país no século XVII, e a diversidade de estilos arquitetônicos é um testemunho da expansão urbana ao longo de mais de quatro séculos (NASCIMENTO, 2016).

Assim, foi incluída nas políticas de preservação a valorização de sítios urbanos pelo seu caráter documental, ampliando as possibilidades de apropriação do patrimônio, como as referências identitárias, ou revelando que, além de uma obra de arte, é um lugar socialmente produzido, carregando elementos de períodos históricos passados. O Iphan nesse período produziu uma metodologia de inventariar centros históricos: conhecer o lugar seria o ponto de partida para a preservação, utilizando a noção de "cidade-documento", conceito usado também em órgãos estaduais e municipais de preservação (MOTTA, 2000). Ainda na década de 1980, outras quatro cidades tiveram seus centros históricos tombados com base nessa metodologia e no conceito de "cidade-documento".

Neste período, as discussões a respeito da preservação do patrimônio na imprensa eram consensuais: não adiantava tombar se o bem não fosse restaurado e utilizado, pois um prédio 
tombado que é mantido fechado e se deteriorando não valoriza a memória da cidade. Para Carlos (2015), é a partir da apropriação dos espaços que se cria a identidade, e somente edificações históricas que tenham usos podem ter significado para os habitantes da cidade e fazer parte de uma identidade coletiva.

O Serviço Social do Comércio (Sesc) foi importante agente, na década de 1970, nas discussões acerca da preservação. Em 1977, o Sesc criou o Programa de Animação Urbana da Baixada Santista (Prourb), e sua primeira edição foi realizada na Casa de Câmara e Cadeia, com o objetivo de trazer atividade culturais e de lazer aliadas à valorização do centro histórico. Uma pesquisa feita durante o evento revelou que $70 \%$ dos participantes foram motivados a comparecer pela curiosidade de conhecer a chamada Cadeia Velha, que esteve fechada por décadas. Demonstrando que a ideia do então diretor do Sesc de "revelar a cidade à sua própria comunidade" (A Tribuna, 1978 apud Araújo, 2008) era compartilhada pela população santista, que tinha interesse em conhecer os edifícios históricos. No ano seguinte, o Prourb foi promovido na Casa do Trem Bélico, e depois das atividades o Sesc entrou com pedido no Iphan e no Condephaat para utilizar o imóvel por 30 anos em regime de comodato. O pedido foi negado, com o argumento de que o Condephaat - que recém-terminara uma restauração da Casa do Trem - estava preparando um plano para o lugar. Mas esse plano não se concretizou e a Casa só foi aberta para abrigar um museu em 2009: lá estão expostos materiais sobre a história de Santos e coleções de armas antigas.

A questão do patrimônio era cada vez mais objeto de discussão da imprensa e de parte da população santista. Araújo apresenta um exemplo bem interessante que aponta a mudança, entre as décadas de 1950 e 1980, do que a população santista considerava como atrativos turísticos. Em um concurso fotográfico organizado em 1955 pelo jornal A Tribuna, cujo objetivo era apresentar o potencial turístico da cidade, as fotografias finalistas, na maioria, eram da praia e dos Jardins da Orla, e só algumas poucas mostravam o porto ou praças. Em um concurso de 1982, com o mesmo objetivo, a praia continuava a ser a principal referência turística das fotografias publicadas, mas também havia imagens de três monumentos intencionados, além da Casa do Trem Bélico, do Mosteiro de São Bento, da Estação Ferroviária, das ruínas do Engenho dos Erasmos e de edifícios históricos de outros municípios da baixada. É possível perceber que os discursos preservacionistas do Iphan e Condephaat estavam sendo incorporados por parcela da população, que passava a valorizar mais determinados marcos da história local. 
Os casos dos tombamentos dos Teatros Coliseu e Guarany são bastante interessantes pela discussão na imprensa e pelo apoio que tiveram da população. O Teatro Guarany sofreu um incêndio em 1981 e a população reivindicou seu tombamento, que foi realizado muito rapidamente pelo Condephaat - mas esse processo jamais foi homologado, e sua proteção não é, portanto, oficial. Somente em 1992 o teatro foi tombado pelo órgão municipal.

Em 1982, foi solicitado ao Condephaat o tombamento do prédio do Teatro Coliseu, que na ocasião tinha passado por algumas descaracterizações e não abrigava um teatro, mas um cinema pornográfico. Com a ameaça de demolição (o proprietário já tinha o alvará da Prefeitura), várias instituições, como o IHG, faculdades, sindicatos e até clubes, endossaram o pedido, com um abaixo-assinado que reuniu 180 nomes. É um caso um pouco diferente dos anteriores (Bolsa do Café e Casarão do Valongo), porque o que motivava o pedido era mais o desejo de ver o retorno do edifício às suas funções originais do que o seu valor arquitetônico. $\mathrm{O}$ significado e a afetividade em relação ao teatro estavam muito presentes naqueles que o haviam frequentado, que nele assistiram a peças, óperas e concertos, e podiam ser reconhecidos na leitura do pedido de tombamento. Mas também os mais jovens tinham interesse em retomar o uso cultural daquele espaço, que tinha capacidade para 2.300 espectadores. Nesse sentido, é interessante destacar uma frase do advogado do dono do imóvel: "Em nome da sociedade não se deve confundir patrimônio histórico com patrimônio sentimental" (CONDEPHAAT P 22.273/82 apud ARAÚJO, 2008, p. 147).

Sobre essa questão, sem dúvidas o sentimento individual em relação a determinado lugar não é suficiente para cogitar seu tombamento, mas o sentimento coletivo é um argumento tão legítimo para a preservação quanto o do valor histórico. E esse valor sentimental coletivo ficou evidente quando num segundo abaixo-assinado foram recolhidas 700 assinaturas em apenas um dia. Apesar de o processo de tombamento estar em curso, modificações foram feitas às escondidas, como a retirada do palco original e dos camarins. Entraram então com um pedido, junto ao governo estadual, de desapropriação do teatro, paralelamente à solicitação semelhante feita em relação ao Teatro Oficina em São Paulo. No entanto, somente o teatro da capital foi desapropriado. Em 1988, o Condephaat tombou o Teatro Coliseu, mas suas portas só foram reabertas ao público 18 anos depois. 
Tabela 4: Bens tombados pelo Condephaat em Santos-SP

\begin{tabular}{|l|r|r|r|}
\hline \multicolumn{1}{|c|}{ Bem tombado } & $\begin{array}{c}\text { Data do } \\
\text { processo }\end{array}$ & $\begin{array}{c}\text { Data do } \\
\text { tombamento }\end{array}$ & \multicolumn{1}{|c|}{ Ex-officio } \\
\hline Casa de Câmara e Cadeia & 1973 & $13-12-1974$ & Sim -1959 \\
\hline Ruínas do Engenho São Jorge dos Erasmos & 1973 & $13-12-1974$ & Sim -1963 \\
\hline Igreja e Mosteiro de São Bento & 1973 & $15-08-1979$ & Sim -1948 \\
\hline Casa do Trem Bélico & 1973 & $03-12-1980$ & Sim - 1940 \\
\hline Igreja da Ordem Terceira de Nossa Senhora do Carmo & 1973 & $11-09-1981$ & Sim - 1940 \\
\hline Bolsa Oficial do Café & 1974 & $24-09-1981$ & Não \\
\hline Casa da Frontaria Azulejada & 1982 & $14-05-1982$ & Sim - 1973 \\
\hline Casarão do Valongo & 1974 & $05-02-1983$ & Não \\
\hline Serras do Mar e de Paranapiacaba & 1979 & $08-06-1985$ & Não \\
\hline Outeiro de Santa Catarina & 1985 & $11-04-1986$ & Não \\
\hline Ruínas do Engenho do Rio Quilombo & 1985 & $11-04-1986$ & Não \\
\hline Vale do Quilombo & 1987 & $24-10-1988$ & Não \\
\hline Teatro Coliseu & 1982 & $21-12-1989$ & Não \\
\hline Ilhas, ilhotas e lajes & 1989 & $26-03-1994$ & Não \\
\hline Conjunto de Santo Antônio do Valongo & 1982 & $30-09-1995$ & Não \\
\hline Museu da Pesca & 1987 & $04-04-1998$ & Não \\
\hline Canais e estações elevatórias & 2000 & $18-06-2006$ & Não \\
\hline Escola Barnabé & 1986 & $23-07-2010$ & Não \\
\hline Escola Dr. Cesário Bastos & 1986 & $23-07-2010$ & Não \\
\hline Escola Visconde São Leopoldo & 1986 & $23-07-2010$ & Não \\
\hline Jardins da Orla & 2001 & $26-08-2011$ & Não \\
\hline Escola Escolástica Rosa & 2011 & $23-08-2013$ & Não \\
\hline *lista atualizada em dez de 2015 & & & \\
\hline
\end{tabular}

Fonte: Condephaat, atualizada em dezembro de 2015.

O tombamento do Casarão Branco, atual Pinacoteca Benedito Calixto, foi bastante interessante, pelo envolvimento da população e pelas ações de seus proprietários. O sobrado do século XIX pertenceu a várias famílias no início do século XX e desde 1937 pertencia à família Canero. Em 1979, o prefeito de Santos anunciou que o imóvel seria desapropriado para sediar a Câmara Municipal. Mas dois dos sete herdeiros da casa não aceitavam os valores propostos e um deles, aguardando as decisões judiciais, transformou o casarão em um cortiço, abrigando cerca de 20 famílias. Artigo do jornal A Tribuna relatava que a casa se encontrava em condições precárias: vidraças quebradas, parte do teto havia ruído, rachaduras, etc. No início da década de 1980, a imprensa fazia apelos ao poder público para tombar o imóvel, que era um dos últimos casarões da orla da praia. Em 1986, a Prefeitura conseguiu a desapropriação e decidiu transformar o casarão em sede da Pinacoteca Municipal, cujo projeto, de 1962, ainda não saíra do papel. Somente em abril de 1992 a Pinacoteca Benedito Calixto foi inaugurada.

A Casa de Câmara e Cadeia, também conhecida como Cadeia Velha, foi construída entre 
1838 e 1869 e funcionou como presídio até 1958, quando foi desativada e, no ano seguinte, tombada em nível federal. Da década de 1960 até 1984 o Iphan desejava que o edifício se tornasse o Museu dos Andradas, mas em 1984 o governo estadual assumiu a gestão da casa e a transformou em delegacia regional de Cultura. Dez anos depois o espaço passou a sediar as Oficinas Culturais Pagu, onde eram realizados cursos de artes plásticas, teatro, cinema, música e dança, entre outros. Em dezembro de 2011, a Cadeia Velha foi fechada para reforma e os cursos foram interrompidos, e a oficina só retomou essas atividades dois anos depois, mas em outro imóvel, em outro bairro. A centralidade da Oficinas Pagu na Cadeia Velha era um grande atrativo: sua localização ao lado da rodoviária e de um terminal de ônibus municipais facilitava a participação de pessoas de todos os bairros e até de outros municípios da Baixada Santista. No ano de 2016 foram abertas mais de mil vagas para os cursos oferecidos.

A partir da reforma da Cadeia Velha, iniciada somente em 2014 (cujo custo foi de R\$ 11 milhões $\left.{ }^{68}\right)$, outras destinações foram discutidas para o prédio, como abrigar o Museu da Baixada Santista e tornar-se a sede da Agência Metropolitana da Baixada Santista (Agem). Depois de muitos protestos dos artistas e dos participantes das oficinas, o governo estadual chegou a um acordo em maio de 2017 para reinstalar a Oficinas Pagu no imóvel, que será administrado pela Agem.

No período entre a transferência das oficinas para outro bairro e a definição da Secretaria de Cultura de que elas retornariam à Casa de Câmara e Cadeia, muitos frequentadores se posicionaram contra a instalação de um museu no edifício. A pesquisadora Tathianni Cristini Silva nos forneceu cópias de debates em redes sociais sobre o assunto:

O local está sendo reformado e a Prefeitura quer fazer "mais um museu". A cidade já tem vários museus e, recentemente, foram gastos milhões no Museu Pelé, que não vem dando certo. Já tem o Museu do Café, o da Pesca, etc. Os artistas de Santos querem que o local volte ao ser um centro de fomentação e criação cultural para os artistas de santos (sic), pois os museus já existem. Não é ser contra museus, de forma alguma, mas de incentivar outras manifestações. - N. M.

Precisamos ampliar os espaços de diálogo sobre o que é museu e sobre a capacidade de interagir destes espaços com as comunidades do entorno. Acho que falta a noção de que museu é um lugar público e de construção de conhecimento. Ele pode ser local de encontros culturais, e incentivar as manifestações artísticas locais. - P. L.

Os dois depoimentos, escritos em debate sobre a pichação nos tapumes que circundavam a

68 US\$ 4.695.637,10. Valor convertido segundo taxa de câmbio de 01 jan. 2014. (R\$ 13.229.068,60 em março de 2018). 
Cadeia Velha (figura 36), mostram que a cidade que até algumas décadas atrás não possuía museus e cujos registros da imprensa sugeriam que seus habitantes queriam museus, hoje sente que estes estão pouco voltados para os seus cidadãos. Talvez por terem sido construídos com o intuito de aumentar o turismo fora de temporada, ou por não terem atividades participativas, que dialoguem com a população local. A preferência pela continuidade das Oficinas Pagu em vez da instalação de um museu demonstra que ao menos uma parcela da população prefere protagonizar atividades culturais a visitar passivamente mais uma exposição em mais um museu. O conflito é criado pela função e pelas possíveis apropriações do equipamento público, as oficinas voltadas para a população santista ou um museu para compor os roteiros turísticos.

Figura 36: Tapumes no envoltório da Casa de Câmara e Cadeia, Santos-SP - 2015.

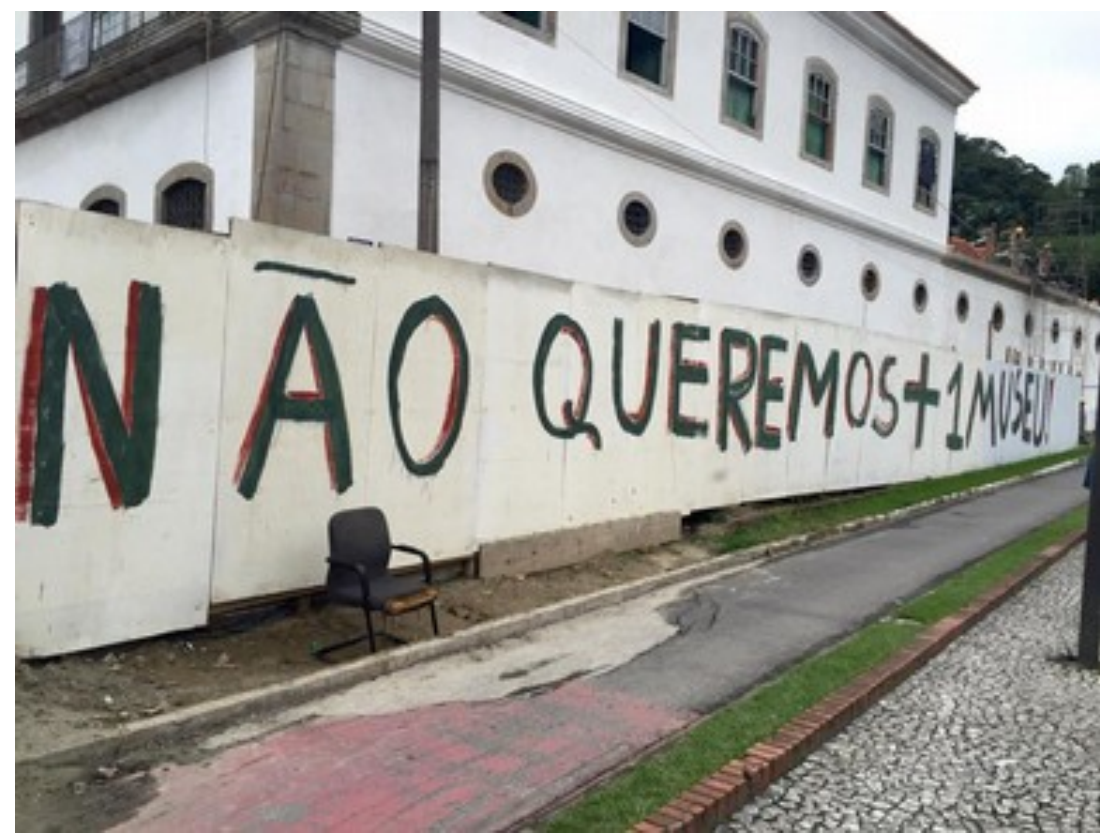

Fonte: Fotografia cedida pela Dra. Tathianni Cristini Silva.

Já as discussões na imprensa sobre os teatros, o Casarão Branco, a Casa da Frontaria Azulejada e também o Museu de Arte Sacra, levaram o poder público a criar comissões especiais de vereadores para tratar da preservação do patrimônio. Foram realizados debates com convidados estudiosos da questão patrimonial e também um passeio histórico pelo centro, para chamar a atenção para o estado de conservação das edificações - a guia foi a professora Wilma Terezinha e quase 300 pessoas se inscreveram para participar da atividade. As faculdades e o Sesc também organizaram debates, e um deles contou com a participação de Lina Bo Bardi e de conselheiros do Condephaat e do Iphan. Com isso, em 1985, deu-se andamento ao processo de desapropriação da Casa da Frontaria Azulejada e criou-se uma 
comissão para discutir a preservação do Casarão Branco.

Em 1989, no $1^{\circ}$ Fórum de Debates sobre o Patrimônio Cultural da Cidade, realizado pela Secretaria de Cultura, foi proposta a criação de um conselho municipal para a proteção do patrimônio. A proposta foi aceita pela Prefeitura, que criou o Conselho de Defesa do Patrimônio Cultural de Santos (Condepasa). No entanto, somente em 1991 o órgão foi regulamentado e pôde iniciar suas atividades.

Apesar das mudanças, desde a década de 1970, na preservação do patrimônio e a participação de camadas da população nos processos de tombamento, a escolha do que é protegido segue tendo um caráter elitista. Santos tem uma larga história abolicionista (oficialmente conhecida como "Terra da liberdade e da caridade"), teve uma grande participação feminina neste movimento e foi declarada a abolição da escravatura no seu território em 27 de fevereiro de 1866, 12 anos antes da Lei Áurea (GITAHY, 1991). Mas não há uma memória dessa história além da toponímia de bairros e ruas, quem sabe que o Jabaquara foi um quilombo com mais de 5 mil pessoas?

A memória operária também não está presente no patrimônio protegido. $\mathrm{O}$ casarão do sindicato dos estivadores, por exemplo, está relativamente bem preservado, mas não é protegido em nenhum nível, nem mesmo pelo Alegra Centro. O porto de Santos tem uma larga história de mobilização de trabalhadores pela conquista de seus direitos que tampouco é destacada nos museus e centros culturais da cidade. A própria APC 2 no Paquetá parece uma tentativa de apagar a memória da habitação dos trabalhadores ao fomentar o restauro das fachadas originais, recuperando a memória do curto período em que foram residencias unifamiliares, antes das classes de rendimentos mais elevados deixarem o bairro.

O Alegra Centro, já apresentado no capítulo 1, é o primeiro projeto de intervenção no patrimônio de forma mais ampla, para além da reforma pontual de imóveis. O projeto foi criado a partir dos perímetros de entorno dos bens tombados, em um momento em que a população santista já tinha mais contato com a temática do patrimônio e em que o turismo fora das praias passou a ser mais procurado. Ele se inspirou em projetos de recuperação do patrimônio de outras cidades brasileiras, que veremos em seguida. 


\subsection{O patrimônio habitado}

Habitações tombadas não são exatamente uma novidade, mas era geralmente a moradia das elites que era considerada digna de preservação, e só nos anos 1980 começaram as discussões no Brasil sobre preservar habitações populares. Naquela década duas vilas operárias foram tombadas em nível federal em Petrópolis - RJ, pelo seu valor histórico como retrato de uma forma de urbanização, não pelo seu valor estético. Também em 1980, a Vila Economizadora em São Paulo foi tombada pelo Condephaat; esse conjunto do início do século XX tinha, originalmente, 134 casas, e é um exemplar das vilas operárias que eram construídas pela iniciativa privada, mas com apoio do Estado, com o ideário de ser uma habitação onde se preservasse a moral e a higiene da família e uma forma de combate aos cortiços (MOTTA, 2000).

A Vila Maria Zélia, na zona leste da capital paulista, foi construída em 1916 para abrigar as famílias dos trabalhadores da fábrica de tecidos de Jorge Street. O conjunto se destacava por ter escolas, igreja, consultório de médico e dentista e comércio, além das mais de 200 casas. Por dívidas dos donos da fábrica, na década de 1930 a vila passou a ser propriedade do IAPI, e a partir dos anos 1960 as casas foram colocadas à venda para os próprios moradores. Hoje alguns imóveis, como os antigos armazém e escola, pertencem ao INSS, e o Ministério Público chegou a entrar com ação para que o instituto reforme esses edifícios, que estão em péssimo estado de conservação. Já as casas estão, em geral, bem preservadas, porque não deixaram de ser habitadas nestes mais de 100 anos de existência. O conjunto foi tombado pelo Condephaat e pelo Conselho Municipal de Preservação do Patrimônio Histórico, Cultural e Ambiental da Cidade de São Paulo (Conpresp) em 1992.

A preservação desse tipo de edificações é uma ação de valorização da memória da classe operária, é um esforço de manter o suporte espacial da memória e seus conteúdos.

A construção do lugar se revela, fundamentalmente, enquanto construção de uma identidade, logo, a memória liga o tempo da ação ao lugar da ação, ao uso e a um ritmo. Assim, espaço e tempo, uso e ritmo se revelam em sua indissociabilidade através da memória. E a história particular de cada um se realiza numa história coletiva, onde se insere, e em relação à qual ganha significado (CARLOS, 2015, p. 55).

Outro caso interessante de preservação da moradia das classes trabalhadoras é o do tombamento de conjuntos habitacionais, sobretudo dos IAPs, considerados uma herança arquitetônica do período de industrialização brasileira. Muitos, de forma similar à Vila Maria 
Zélia, não eram somente habitações, mas possuíam um ideal de cidade e um ideal de morar. Um dos conjuntos mais destacados por sua arquitetura inovadora é o Pedregulho, no Rio de Janeiro, que foi inaugurado na década de 1960, com 328 apartamentos, e tombado em 1986 em nível municipal e em 2011 em nível estadual. O Pedregulho passou por um processo de restauro em 2015 que revelou os inúmeros problemas na recuperação de construções modernas, como a dificuldade de encontrar fornecedores e materiais similares aos originais (NASCIMENTO, 2007).

Esses são casos de habitações consideradas como patrimônio que já na sua concepção eram "moradias-modelo", eram entendidas como formas exemplares de morar com conforto, saúde e dignidade. O tratamento dado pelos órgãos de proteção não pode ser o mesmo quando as construções, sem dúvida históricas e testemunhos de uma época, são habitações insalubres, apinhadas e em péssimo estado de conservação. Muitas construções históricas no centro das cidades brasileiras tornaram-se cortiços, algumas têm essa função há décadas e mesmo na maior parte de sua existência. Veremos alguns casos do tratamento dado a esses edifícios pelos órgãos de patrimônio e outras instituições públicas nas cidades de Recife e Salvador, para tentar construir um panorama dos desafios e possibilidades existentes, antes de abordar a realidade dos cortiços de Santos.

Uriarte (2010) realizou uma pesquisa sobre as intervenções no Bairro do Recife e no Pelourinho (Salvador), que, apesar de suas diferenças, chegaram a um resultado parecido: a manutenção de uma pequena parcela dos moradores antigos e de baixa renda e uma modificação quase completa do uso desses espaços, direcionando-os para o lazer e o turismo. $\mathrm{Na}$ antiga capital da colônia, os grandes latifundiários e os funcionários de alto escalão do governo-geral habitavam casarões no Pelourinho. Somente no século XIX essas elites se mudaram para outros bairros, em especial na zona sul da cidade. Como em outros centros históricos, com a saída dessas famílias do centro, as habitações foram alugadas, subdivididas e transformadas em cortiços. Já na década de 1930 o Pelourinho era conhecido como área de concentração de cortiços. Na década de 1950, a construção do Centro Administrativo da Bahia e de um novo terminal rodoviário longe do centro histórico levaram a uma perda relativa de sua importância como lugar de concentração de comércio e serviços. Na década de 1990, o centro estava bastante esvaziado das suas funções tradicionais, e muitos casarões passaram de mal conservados para ruínas - o número de ruínas subiu de 13 em 1969 para 86 em 1993. 
O que distingue o Centro Histórico de Salvador (CHS) de outros centros históricos é que grande parte de seus casarões é propriedade do poder público: o Instituto do Patrimônio Artístico e Cultural da Bahia (IPAC) possuía em 1995 42,9\% dos imóveis da área. O que facilitaria medidas para democratizar esse espaço e manter a população trabalhadora de baixos rendimentos nesse bairro, paralelamente ao incentivo ao turismo. No entanto, a partir da década de 1990, as sete etapas do Projeto de Recuperação do CHS causaram a expulsão de mais de 3 mil moradores para outras partes da cidade. A maior parte da população moradora do CHS aluga sua moradia e tem baixa escolaridade (36\% dos chefes de família tem até quatro anos de estudo). ${ }^{69}$

Por outro lado, o valor que os comerciantes pagavam ao IPAC pelo uso de imóveis na área era muito inferior ao valor de mercado - segundo Uriarte, em 1993, 43\% desses comerciantes declararam pagar aluguel inferior a $\mathrm{R} \$ 50,00$ por mês. Houve uma decisão política de subsidiar o aluguel dos comerciantes, mas não o aluguel de moradia da população trabalhadora que já habitava a região há décadas. A ideia de que a população que morava naquele espaço não poderia continuar lá para que fosse realizada a preservação do patrimônio era defendida e divulgada pelo IPAC. Para a diretora do instituto, Adriana Castro:

A equação era transformar um bairro decadente habitado por desempregados, prostitutas e traficantes numa região que conjugava preservação histórica e valor imobiliário. Daí a saída da população. "Marginal tem que ser tratado pela polícia ou órgãos assistenciais, não pelo patrimônio histórico", defende Adriana "Não pode haver romantismo: marginal não pinta a casa e joga fezes na rua." (sic) (CARVALHO, 1994).

As afirmações preconceituosas da então diretora do IPAC demonstram que não havia nenhum compromisso com os moradores do Pelourinho; do seu ponto de vista a solução para tornar aquele espaço atrativo para visitantes e turistas era a expulsão da população pobre dos casarões. Adriana, no entanto, não poderia estar mais equivocada no que tange à preservação do casario colonial: se não fossem os trabalhadores que habitavam e mantinham os casarões, ainda que em situações precárias de habitabilidade, mas com limpeza, cuidados cotidianos e pequenos reparos, o número de edificações em ruínas seria muito maior. A posição do instituto também era equivocada quanto a pensar que bens históricos estão acima da função social da propriedade. É contrário ao direito à moradia previsto na Constituição Federal, e até mesmo cruel, expulsar as pessoas de suas casas para transformá-las em um museu a céu aberto no qual turistas estrangeiros podem admirar a arquitetura barroca. Concordamos com a

69 Dados do Censo de 2000. 
afirmação de Azevedo: "Mitificou-se o patrimônio cultural como algo intangível, fora da realidade social e econômica dos mortais, o que serve de pretexto à omissão das autoridades ligadas ao desenvolvimento urbano e à habitação" (AZEVEDO, 1988, p. 36).

Uma pesquisa da Companhia de Desenvolvimento da Região Metropolitana de Salvador em 1999 averiguou que o uso exclusivamente turístico do Pelourinho não foi bem-sucedido, e muitos comércios fecharam depois de alguns anos. Foi feita então a proposta de um uso misto: turismo e política habitacional. Assim, foi desenhada a sétima etapa do projeto de recuperação, com a desapropriação e reforma de imóveis, que teriam unidades habitacionais de, em média, $37 \mathrm{~m}^{2}$ para financiamento da Caixa, com prestações acessíveis à população que já morava no bairro. Segundo Uriarte (2012), apenas 10 apartamentos foram concluídos e entregues em 2007, em 2 dos 76 casarões incluídos no projeto - dez anos depois, $23 \%$ das famílias ainda não tinham recebido seus imóveis. Além disso, um programa habitacional voltado para funcionários públicos no mesmo bairro destinou-lhes 31 casarões, que se tornaram 102 apartamentos.

Já no caso de Pernambuco, o Bairro do Recife não era tão residencial como o Pelourinho, embora as classes trabalhadoras tenham se instalado lá também no final do século XIX, utilizando até mesmo armazéns e escritórios ligados ao porto e na época já desativados. Em um dos projetos pensados para a recuperação do patrimônio histórico a população que lá habitava teria seus imóveis reformados e se manteria no local. Foi um plano inspirado no modelo de Bolonha, caso famoso de recuperação de patrimônio histórico combinado com habitação social. Naquele momento o bairro tinha somente 566 moradores, o que, comparado aos 4.500 habitantes do Pelourinho, significaria um desafio bem menor para mantê-los nas suas moradias originais. Este projeto, entretanto, não foi posto em prática.

Em 1993, iniciou-se um projeto inspirado no Vieux Carré de New Orleans, voltado para o lazer e a cultura, cujo foco seria a criação de bares e restaurantes na Rua do Bom Jesus. Com mais limpeza, iluminação e segurança, fachadas restauradas e sem trânsito de veículos, a rua se tornou uma atração das classes alta e média da cidade - e contrasta com o restante do bairro. Em dias de grandes eventos cerca de 15 mil pessoas frequentam o espaço (URIARTE, 2010).

Na primeira década do século XXI, diminuíram os investimentos da Prefeitura do Recife e aumentaram os investimentos federais e estaduais, a partir de um projeto do governo do Estado de Pernambuco chamado Porto Digital, que tinha o intuito de atrair empresas de 
tecnologia para o bairro, e do programa Monumenta, que construiu, com recursos do BID, um shopping center e um complexo de cinemas, cafés e restaurantes e estacionamentos. Assim, houve uma expansão da área que foi reformada e um grande aumento dos preços de aluguel e venda de imóveis.

A preservação não é mais importante do que as pessoas que necessitam do patrimônio para viver (CANCLINI, 1994) e, no entanto, os projetos de preservação de Salvador e do Recife não vão nesse sentido, pois privilegiam o uso turístico e de lazer em detrimento das populações que ali moravam. Quando, sem dúvida, muito menos restaria desse patrimônio se uma parcela dos trabalhadores de baixos rendimentos não tivesse ali se instalado e mantido o casario, ainda que sem pintar as paredes, como afirmou a diretora do IPAC, mas impedindo que se transformasse em ruínas.

Nos dois projetos prevaleceu o espaço como mercadoria, passível de ser consumida pelos turistas, do que como uso, como habitat, no momento em que as atividades turísticas se tornavam atrativas como possibilidade de acumulação do capital, aproveitando as características particulares dos lugares, mas desconectando a paisagem, o casario, da vida do lugar. O cartão-postal e os roteiros turísticos escondem as desigualdades, os conflitos e a história recente, privilegiando a narrativa dos habitantes daquele lugar no século XVIII, não a dos que permanecem lá ou foram recentemente expulsos. A apropriação desses espaços é cada vez mais subordinada ao mercado, na construção de uma cidade como negócio (CARLOS, 2015).

O Alegra Centro em Santos foi inspirado nos projetos de recuperação do patrimônio da Rua do Bom Jesus e do Pelourinho. A ideia era que na Rua XV de Novembro, que termina no prédio da Bolsa do Café, os imóveis recuperados fossem transformados em cafés, restaurantes e bares, e a Prefeitura investisse em eventos culturais para atrair o público. Desde sua inspiração estava claro que o projeto não levaria em consideração a população moradora dos casarões históricos.

A recuperação do patrimônio histórico pode ser aliada a políticas de habitação social. A experiência do Partido Comunista Italiano na Prefeitura de Bolonha no final da década de 1960 tornou-se um modelo e é bastante citado na literatura sobre o tema. O planejamento das ações municipais para os restauros foi feito com a criação de um orçamento participativo.

O sucesso da experiência de Bolonha decorre do fato de ter-se, pela primeira vez, tentado restaurar um centro histórico não em função do turismo, senão da melhoria de vida de seus habitantes. Partindo do princípio de que o centro 
histórico é um patrimônio da comunidade, a Municipalidade de Bolonha iniciou seu programa desapropriando e recuperando setores deteriorados que eram em seguida devolvidos a seus ocupantes (AZEVEDO, 1988, p. 41).

Em seguida, em decorrência de crise econômica, também se admitiram capitais privados no projeto, mas adotando leis que impedissem a especulação imobiliária. Assistência técnica, financiamento e incentivos foram oferecidos aos proprietários dos imóveis e os inquilinos que tiveram seus aluguéis reajustados por causa das melhorias realizadas e não tinham condições de pagá-los podiam pedir complementação à Prefeitura e permanecer no imóvel.

Bolonha tem seu centro caracterizado por pórticos nos térreos dos edifícios, onde funcionam variadas atividades comerciais, enquanto os andares superiores são destinados ao uso habitacional.

A Carta de Veneza - International Council of Monuments and Sites (ICOMOS), de 1964, foi um importante ponto para novas experiências, pois alterou ideais de salvaguarda do patrimônio, partindo da ideia de preservação para a de conservação, em que se entende a inevitabilidade de certas mudanças (SAMPAIO, 2017). Por exemplo, as questões de obsolescência funcional, em que as estruturas de cozinha e/ou banheiro originais não são compatíveis com as necessidades contemporâneas.

A cidade do Porto, em Portugal, teve uma experiência que também aliou habitação social e preservação do patrimônio no bairro Barredo, de 1974 a 2003. No contexto da redemocratização portuguesa, o projeto, de caráter participativo, foi desenvolvido em resposta às reclamações da população local sobre a insalubridade no bairro "Opera-se nas diversas dimensões da cidadania e são tomadas medidas de reabilitação urbanística, provendo, além da habitação social, equipamentos urbanos então inexistentes, essenciais para a fixação da população local” (SAMPAIO, 2017, p. 57). Assim como em Bolonha, o financiamento e o apoio técnico da Prefeitura viabilizavam aos proprietários as reformas e asseguravam aluguel subsidiado a uma parcela dos moradores.

Em ambas experiências, evidencia-se o papel-chave da moradia para a salvaguarda da significação cultural do patrimônio urbanístico como um instrumento qualificador da vida na cidade contemporânea. O patrimônio habitado qualifica a moradia e valoriza a memória urbana (SAMPAIO, 2017, p. 59).

No centro histórico de Quito também se implantou uma política interessante de recuperação do patrimônio após um terremoto, em 1987. Foi criado o Fundo de Salvamento do Patrimônio Cultural (FONSAL) para recuperar a área que é declarada Patrimônio Cultural da Humanidade pela UNESCO e outras áreas atingidas da cidade. Seus principais objetivos são: 
a conservação e recuperação do centro histórico e outras áreas patrimoniais; sua atuação se centra predominantemente na restauração de monumentos e edifícios de interesse, como também na reabilitação e melhora de setores, conjuntos e edificações de habitação, do equipamento urbano, os espaços públicos e a infraestrutura das áreas patrimoniais da cidade e do Distrito Metropolitano de Quito (CIFUENTES, 2008, p. 107, tradução nossa). ${ }^{70}$

Neste caso, como a maior parte dos imóveis são habitados por seus proprietários, que têm pequenos comércios no térreo e vivem no andar superior, a manutenção da população é facilitada. O FONSAL conseguiu aliar a conservação de patrimônios de interesse turístico, a melhoria viária (com a construção de estacionamentos no entorno, o fechamento de ruas ao trânsito de veículos, tornando-as exclusivas para pedestres, e, atualmente, a construção do metrô) e a manutenção no local dos habitantes e de pontos de comércio bastante tradicionais.

O Projeto Piloto Olinda, do Programa de Recuperação e Revitalização de Núcleos Históricos (PRNH), teve início em 1981, e tinha três objetivos principais: 1) financiar e restaurar imóveis de uso habitacional com valor histórico em áreas com infraestrutura urbana; 2) restaurar e preservar conjuntos de imóveis de valor cultural, histórico e artístico, de usos e funções diversas; e 3) manter a população residente e restaurar imóveis desocupados ou subutilizados para aumentar o estoque habitacional (GUSMÃO, 2011). Para isso, foi criada uma linha de crédito do $\mathrm{BNH}$, que arcou com $80 \%$ do orçamento (a Prefeitura assumiu o restante); o banco não possuía até então nenhum projeto de recuperação de estoque imobiliário já existente. Depois de realizado um extenso levantamento, o projeto passou a incluir também financiamento para reformas, ampliações e saneamento para habitações subnormais contíguas ao centro histórico. O projeto previa um subsídio para compensar os moradores pelas restrições legais para alterações nos seus imóveis. O subsídio variava de 5\% a 50\%, dependendo do tipo de reforma solicitada e da faixa de renda do proprietário. Um sinal da organização das associações de moradores e da participação popular que teve o projeto foram as decisões de que os imóveis não seriam dados como garantia do financiamento ao BNH e de extensão do número de parcelas. Muitas casas do núcleo histórico apresentavam fachadas bem conservadas, mas vários problemas em suas áreas internas: ausência de instalações hidráulicas e sanitárias, esgoto a céu aberto, cupim nas estruturas de madeira e infiltrações de água. Em 1985, o Projeto Piloto Olinda estimulou a alteração de alguns pontos da legislação federal de

70 “[...] la conservación y recuperación del centro histórico y otras áreas patrimoniales; su actuación se centra predominantemente en la restauración de monumentos y edificios de interés, como también en la rehabilitación y mejora de sectores, conjuntos y edificaciones de vivienda, del equipamiento urbano, los espacios públicos y la infraestructura de las áreas patrimoniales de la ciudad y del Distrito Metropolitano de Quito" (CIFUENTES, 2008, p. 107). 
preservação $^{71}$ para possibilitar que os moradores fizessem ampliações nas casas para instalação de cozinhas e banheiros, que frequentemente se encontravam nos porões, localização bastante insalubre (GUSMÃO, 2011).

Após a extinção do BNH, em 1986, a Caixa Econômica Federal não deu seguimento ao financiamento do projeto e a Prefeitura de Olinda foi a única responsável pelo seu orçamento até 1989, quando foi encerrado. Atendeu 175 contratos, em 104 imóveis, apesar de ter 437 inscritos. O projeto foi exemplar em resolver a questão da obsolescência funcional e física das habitações, e gastando menos recursos do que seriam necessários para a construção de novas moradias.

Para Azevedo, não se pode justificar o estado de deterioração do patrimônio simplesmente pelos poucos recursos disponíveis, pois não é possível preservar conjuntos históricos sem uma política integrada de desenvolvimento urbano.

Um dos pontos fundamentais para romper este impasse é conscientizar as comunidades para o valor social e econômico deste patrimônio, que precisa ser reciclado para cumprir plenamente sua função social e cultural. Esta recuperação é um direito da comunidade. Sem integração na vida contemporânea, o patrimônio cultural é uma farsa (AZEVEDO, 1988, p. 36).

A seguir, veremos a história da Associação dos Cortiços do Centro de Santos, suas atividades e a construção do condomínio Vanguarda, assim como suas relações políticas, incluindo seu enfrentamento com a Prefeitura em relação ao programa Alegra Centro.

71 Rerratificação da Notificação 1.155/79. 


\title{
Capítulo 4: Mudar sem se mudar: a resistência da Associação dos Moradores dos Cortiços do Centro de Santos-SP
}

\author{
Eu acredito é na rapaziada \\ Que segue em frente e segura o rojão \\ Eu ponho fé é na fé da moçada \\ Que não foge da fera e enfrenta o leão \\ Eu vou à luta com essa juventude \\ Que não corre da raia a troco de nada \\ Eu vou no bloco dessa mocidade \\ Que não tá na saudade e constrói \\ A manhã desejada \\ Gonzaguinha
}

A Associação dos Cortiços do Centro de Santos iniciou suas atividades em 1996 e tinha como presidente um morador do Paquetá, Jorge Mascareli, ligado ao Partido da Social-Democracia Brasileira (PSDB), partido que passou a governar o Estado de São Paulo em 1995, com a posse de Mário Covas. ${ }^{72}$ Nesse período já havia a promessa dos apartamentos da CDHU no centro de Santos, que seriam por volta de 600 UHs, mas se concretizaram nos 113 apartamentos do PAC entregues em 2008. Essa primeira gestão da ACC pressionava os associados a se filiarem ao PSDB, alegando que assim seria mais fácil conseguir um apartamento da CDHU.

$\mathrm{Na}$ época, minha mãe [Samara Faustino] era uma associada, tava em busca da casa própria, do apartamento que era promessa por vários políticos na época, a associação na época era partidária, então sempre teve o apoio de certos políticos, prometiam para as pessoas que não entendiam nada "vote em mim que eu vou te dar uma casa, vote em mim" (depoimento de Nay Faustino $^{73}$ - março de 2018).

Em 2002, na eleição de uma nova diretoria para a ACC, faltava alguém como candidato para o cargo de secretário. Muitos associados propuseram o nome de Samara Faustino para o posto, pois ela vivia há muitos anos no bairro, tinha um salão de cabeleireiro e era conhecida por todos; de fato, na assembleia ela foi eleita para assumir esse cargo. Nas reuniões, Samara entrou em conflito com o resto dos diretores, por ver que estavam descadastrando certas pessoas da lista para os imóveis da CDHU e incluindo outras pessoas que eram de bairros distantes. Depois de Samara expôr esses problemas em assembleia, os demais membros da diretoria saíram da associação. "Aí sabe o que eles fizeram, aquela gestão? Me largou, deixou

72 Governos do PSDB no Estado de São Paulo: Mário Covas (1995 a 2001), Geraldo Alckmin (2001 a 2006), José Serra (2007 a 2010) e Geraldo Alckmin (2011 a 2018).

73 Atual presidente da ACC e trabalhadora da padaria "Um Só Coração". 
a associação na minha mão, sumiram todo mundo, presidente, todo mundo, deixaram na mão da secretária. Eu não sabia o que era CNPJ, o que tinha que organizar" (depoimento de Samara Faustino - março de 2018).

A partir daí começou um processo de construção coletiva da associação: o que antes fícava somente sob controle de poucas pessoas da diretoria passou a ser dividido em comissões, muitos associados iam às reuniões com o poder público, houve um desligamento do PSDB. "Desfiliou mais de mil pessoas de uma vez só do partido" (depoimento de Nay Faustino março de 2018). Hoje a ACC frisa, em todas as reuniões e entrevistas com a mídia, que não apoia nenhum partido ou candidato. "Aqui pro pessoal da baixada ela [a ACC] tinha um dono, um vereador que mandava, ela era de alguém. Então nós colocamos que não era de ninguém" (depoimento de Samara Faustino - março de 2018).

Eu não conhecia a associação, não conhecia, e aí alguém que eu não lembro me convidou pra ir, olha tem o cadastro pra casa, pra moradia, só que as reuniões variam de locais. Quando eu comecei a assistir era ali perto do primeiro distrito, aquele colégio ali, Barnabé, era uma desorganização terrível, eu não entendia nada, eu ia por esse impulso dos outros. Depois foi o tempo que a Samara pegou o pleito de presidente, pra ela começar a liderar, mas aí passou muito tempo pra ela poder pegar. Não sei como foi a burocracia deles lá com o escritório, só sei que ela começou, aí eu até trabalhei com eles lá na mesa pra fazer os cadastros, junto com a sobrinha dela, eu tô esse tempo todo, mais de 20 anos, é não Maria de Lourdes? Mais de 20 anos que a gente tá nessa? [...] Então, resumindo, aí eu gostei, tinha os parceiros, o Instituto Elos, que deram luz pra gente, pra Samara, pra poder caminhar; do jeito que eles tavam fazendo, o outro presidente tava fazendo, ela não concordava, quando ela foi tomar a direção, ela teve que caminhar totalmente diferente, porque não era aquilo, que ela tava vendo muito erro (depoimento de Joaquina do Socorro ${ }^{74}$ - março de 2018).

A associação precisava naquele momento de um apoio, uma orientação para transformar seus ideais e demandas em objetivos mais concretos, conhecer os caminhos e possibilidades de conquistar a habitação digna e outros direitos. Seus integrantes procuraram parceiros que pudessem ajudar a lidar com o poder público e a organizar melhor a associação. Fizeram uma parceria com o Instituto Elos, ${ }^{75}$ uma ONG de arquitetos de Santos, fundada em 2000, que tem experiência com pequenos projetos comunitários, como reformas de centros comunitários,

74 Vice-presidente da ACC e trabalhadora da padaria "Um Só Coração".

75 ONG formada por arquitetos a partir de uma experiência de um grupo de estudantes na reforma do Museu da Pesca de Santos. A atuação da ONG parte das demandas e potencialidades das comunidades, em cada caso há o levantamento das necessidades e dos objetivos e as pessoas são instigadas a pensar coletivamente em como atingi-los. Um dos princípios é caminhar para que cada comunidade tenha autonomia para realizar projetos futuros - o Instituto Elos procura dar ferramentas e compartilhar conhecimentos para propiciar o surgimento de novas lideranças e novos projetos em cada coletividade em que atua. Mais informações em: http://institutoelos.org/. 
formação de hortas comunitárias, etc. Em 2003, no contexto da $1^{\text {a }}$ Conferência Metropolitana da Cidadania, ${ }^{76}$ foi proposta pelo Instituto Elos - tendo em vista que os moradores do Paquetá se queixavam de não ter espaços de lazer - uma reforma da Praça Nagasaki, que fica atrás do Mercado Municipal e de onde saem as catraias, pequenas embarcações, para o bairro suburbano de Vicente de Carvalho, no Guarujá, do outro lado do Canal de Santos.

Foi reforma da praça, era muito trabalho ali, era tudo quebrado aquela praça ali. Ali era mutirão. Na época as crianças era tudo pequena (depoimento de Maria de Lourdes ${ }^{77}$ - março de 2018).

É uma praça que já estava abandonada há mais de dez anos pelo poder público, aí o Elos formou um trabalho com os jovens, com as senhoras [...] e aí eles ensinaram nosso grupo de jovens a lidar com o poder público, lidar com a Prefeitura e negociar a revitalização, porque a gente queria revitalizar, o grupo de jovens nosso, só que tinha que ter autorização da Prefeitura. [...] No sábado a gente levou 4 ônibus pro Sesc daqui de Santos, com a comunidade, cheio, dividimos em 4 grupos, cada grupo fez uma maquete junto com os arquitetos, que ajudaram, aí voltamos e escolhemos a que ia ser feito no domingo. Aí no domingo foi dia de pôr a mão na massa, as senhoras ficaram na cozinha, as crianças foi que chegou primeiro, depois os pais (depoimento de Nay Faustino - março de 2018).

A ideia central da reforma estava baseada na metodologia da ONG, de promover ações integrando toda a comunidade, em que cada um pudesse contribuir com um aspecto do projeto: doação de materiais (uma lata de tinta, madeira, etc), empréstimo de ferramentas, habilidades, busca de donativos. Com seu trabalho coletivo e a orientação do Instituto Elos, os moradores construíram bancos a partir de pedras de uma demolição, plantaram mudas de árvores (cedidas pela Secretaria do Meio Ambiente da Prefeitura), pintaram um mural. Antes a praça era um ponto onde pessoas despejavam entulho e lixo, onde coletores de material reciclado e ferro-velho queimavam fios para vender o metal. Transformou-se em um lugar de encontro, de brincadeira das crianças, mas sobretudo um exemplo de que a comunidade podia ser protagonista da transformação do seu espaço.

Processos de recuperação de espaços públicos se tornam mais comuns à medida em que restam poucos espaços na cidade que não se tornaram mercadoria na forma de propriedade privada. Uma das principais contradições na reprodução do espaço capitalista é que a produção do espaço (e também das riquezas materiais) é coletiva, enquanto a sua apropriação

76 A Conferência Metropolitana da Cidadania foi um evento organizado em parceria pelo Sesc de Santos, a Universidade Católica de Santos, a Agem, a Prefeitura e sindicatos, entre outros, com debates sobre justiça social, direitos humanos e reformas políticas, além de atividades artísticas. O Instituto Elos foi convidado para dar uma palestra no evento, mas preferiu realizar uma ação coletiva: a organização do mutirão de reforma da Praça Nagasaki.

77 Associada e trabalhadora da padaria "Um Só Coração". 
é privada; dessa forma "as lutas de classe, que se realizam em torno da distribuição da riqueza social gerada pelo produto social do trabalho, desdobram-se em lutas pelo espaço" (CARLOS, 2015 , p. 51). Essas lutas revelam a resistência do valor de uso em um momento em que o mundo da mercadoria tende a se estender a todos os aspectos da vida.

Aí depois que a associação criou uma visibilidade intensa pra cá, a sociedade inteira passou a olhar os cortiços com outra cara, conhecer ela [a associação], que ela participava de tudo quanto é, nossa, Câmara Municipal, os vereadores, quando via a Samara já vinha um monte de gente atrás, ela começou a mostrar pros moradores a importância da participação. (depoimento de Nay Faustino - março de 2018).

Figura 37: Praça Nagasaki, Santos-SP.

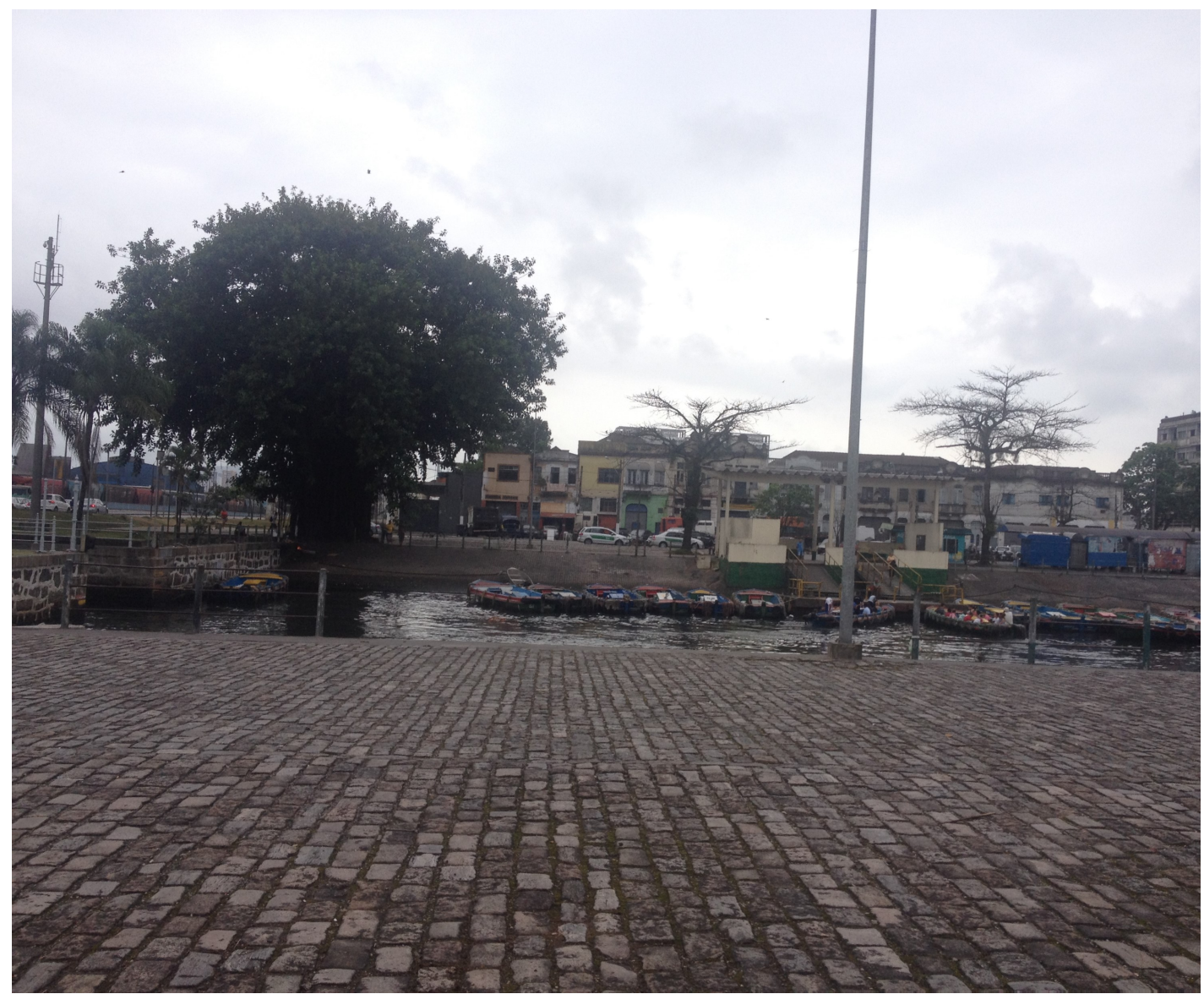

Fonte: Bruna G. Eskinazi - novembro de 2016.

Com o resultado positivo dessa ação realizada em parceria com o Instituto Elos, outros projetos foram pensados, com o objetivo de atender às demandas dos associados, como a falta de vagas em creches (ou a necessidade de creche em horário noturno, para as mães que trabalham à noite) e a falta de empregos. Um grupo de mães iniciou uma busca por um imóvel que pudesse sediar a creche 24 horas e também uma padaria comunitária, para gerar trabalho 
para as associadas, e o Instituto Elos entrou em contato com a ONG Associação Comunidades de Mãos Dadas (ACMD) para auxiliar na arrecadação dos recursos necessários para a compra do imóvel. A ACMD foi formada em 1996 por um grupo de empresários da Baixada Santista, no contexto de criação do Estatuto da Criança e do Adolescente, ${ }^{78}$ para fomentar iniciativas em prol da defesa dos direitos da criança e do adolescente. A ACMD tem atuado especialmente na assessoria a outras entidades, para auxiliar na arrecadação e na melhor gestão de recursos, e para firmar parcerias com o poder público. Entendendo que são as associações e movimentos locais que melhor conhecem a demanda de suas comunidades, a ACMD dá assessoria para ajudá-los a atingirem seus objetivos.

Em julho de 2005, a ACMD realizou na empresa de logística Libra Terminais um café da manhã com empresários, que visitaram alguns cortiços e fizeram uma dinâmica com membros da ACC. Foram arrecadados $\mathrm{R} \$ 65.171,25$, dos quais $\mathrm{R} \$ 30.000,00$ foram destinados à compra do imóvel, $\mathrm{R} \$ 9.478,48$ à reforma (realizada pelo Instituto Elos) e à compra de equipamentos e o restante foi gasto em despesas de cartório, IPTUs atrasados e do ano corrente e despesas bancárias. Os recursos vieram de doações de diversas subsidiarias da Libra Terminais e dos membros da ACMD. O imóvel, na Rua Dr. Cochrane, foi entregue no dia 24 de julho de 2007.

A ideia inicial era montar a padaria no andar térreo do sobrado e construir no fundo um espaço que funcionaria como creche e núcleo da Pastoral da Criança (o projeto arquitetônico está no anexo II). A padaria, inaugurada em janeiro de 2010, funciona de segunda a sábado e serve almoços. Já o espaço para a creche ainda não saiu do papel. ${ }^{79}$

Como as mulheres que lá trabalhariam eram muito próximas, elas decidiram nomear a padaria de "Um Só Coração", uma escolha que mostra as relações de sociabilidade entre as moradoras dos cortiços. Como nessas moradias predominam mulheres chefes de família, elas se ajudam bastante para conseguir trabalhar e cuidar dos filhos - às vezes, por exemplo, uma cuida das crianças para outra poder sair e vice-versa. Assim se estabelecem relações de confiança e solidariedade. As famílias eventualmente mudam de um cortiço para outro, mas quase todas as pessoas entrevistadas moram no bairro há décadas, formando relações de vizinhança bastante fortes.

78 Marco legal e regulatório dos direitos da criança e do adolescente na legislação federal brasileira, publicado em 13 de julho de 1995.

79 Como a entrega desse imóvel e a doação do terreno para a construção do condomínio Vanguarda aconteceram no mesmo período, infere-se que a creche não foi instalada pela impossibilidade dos membros de conciliar a elaboração e a aprovação do projeto habitacional e o cumprimento de todas as exigências da Caixa com a captação de recursos para a construção do espaço da creche. 
Na parte de cima do sobrado são realizadas as reuniões da ACC. No local funciona uma pequena biblioteca, formada com uma arrecadação de livros. A padaria fica em frente do Cemitério do Paquetá e está no perímetro do Alegra Centro, em área classificada com nível de proteção 2 (preservação da fachada, volumetria e telhado). Também está dentro do perímetro da Zeis 3.

Figura 38: Padaria “Um Só Coração” e sede da ACC em sua inauguração, em janeiro de 2010.

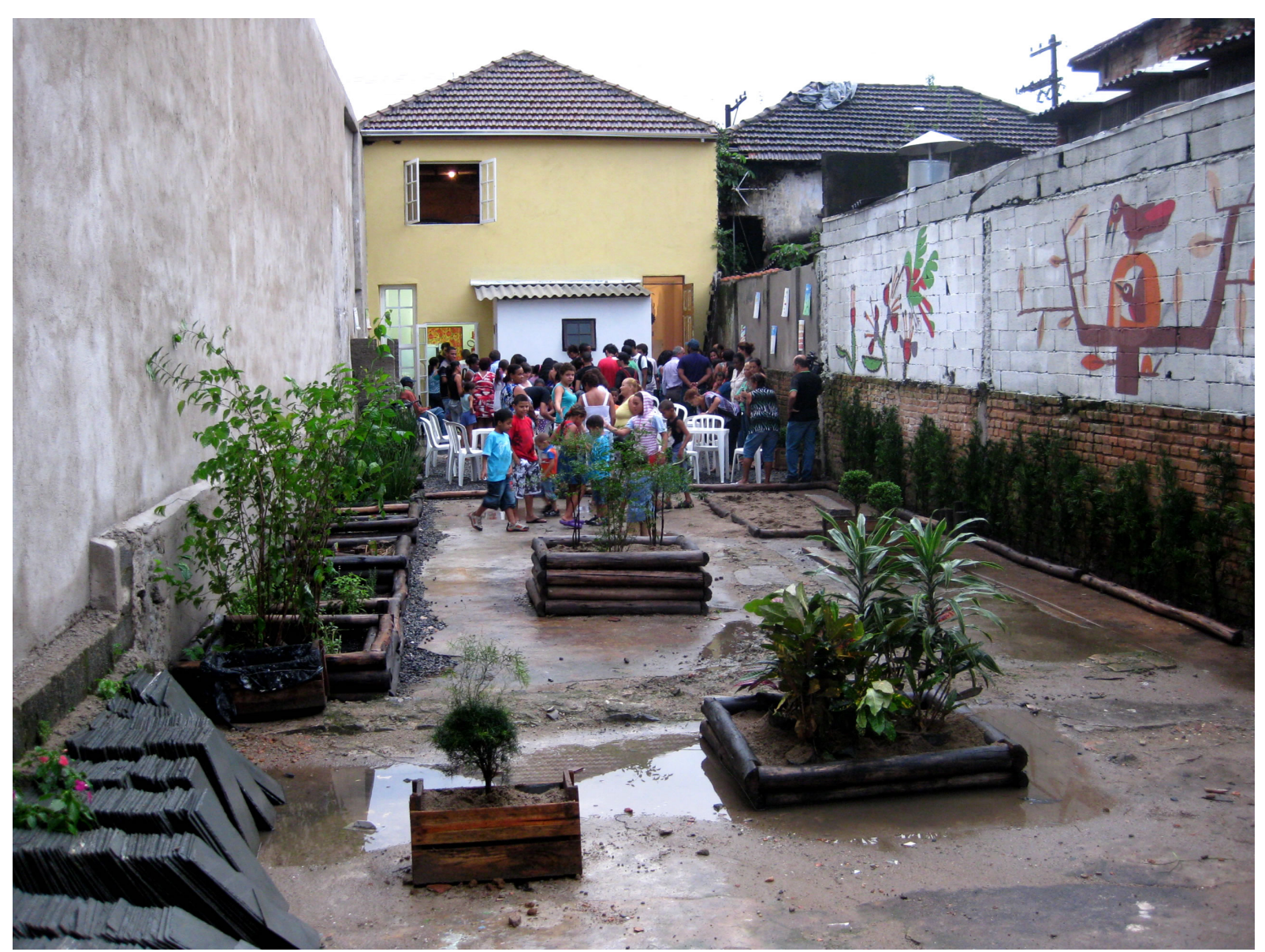

Fonte: Instituto Elos.

Em 2006, outro projeto com o objetivo de gerar rendimentos para as moradoras de cortiços foi criado pela ACC em parceria com o Instituto Elos, o ateliê de bijuterias "Raízes Corticeiras". A ideia era produzir um artesanato diferente, com características ligadas à identidade da comunidade e a partir de técnicas de costura conhecidas pelas integrantes. Elas decidiram fazer colares, pulseiras, chaveiros e marcadores de livros com tecido de chita, por ser um material presente no seu cotidiano. Por ser um tecido barato, é muito utilizado como cortina, para dividir os cômodos dos cortiços, ou para cobrir as portas. A ONG colaborou com a assessoria de design, com o envio de peças para leilões no exterior e a divulgação para 
instituições internacionais parceiras, conseguindo a comercialização dos produtos em uma loja em Boston. A ACC conseguiu apoio por meio de um edital da Petrobras - segundo informações do Instituto Elos, a inscrição nesse edital foi realizada sem auxílio da ONG, demonstrando que o grupo já tinha conquistado autonomia e aprendizado para pleitear recursos. A produção das bijuterias aumentou os rendimentos das 10 mulheres participantes do projeto, e é muito importante para as mães, que podem trabalhar em casa enquanto cuidam dos filhos pequenos.

A questão principal nas atividades da economia solidária é a valorização do trabalhador, das suas experiências e potencialidades, e da sua capacidade de participar coletivamente da gestão da atividade, tendo conhecimento de todas as etapas da produção.

$\mathrm{Na}$ essência, são relações de produção que trazem a inovação de estarem centradas na valorização do trabalho e do trabalhador e não do capital. Essa é uma inovação, uma ruptura na organização socioeconômica que domina a economia mundial: valorizar o trabalho e não o capital (KAPRON, 2002, p. 49).

São atividades econômicas diferenciadas na sua forma de organização e no protagonismo do conjunto dos trabalhadores, mas surgidas de dificuldades concretas de grande parte dos trabalhadores de se inserirem no mercado de trabalho formal, seja por um problema de desemprego gerado por uma crise econômica, seja por um problema mais antigo e estrutural. Um mercado explorador e excludente levou os trabalhadores a criar coletivamente oportunidades de trabalho mais justas e inclusivas (NUNES, 2002).

Além da padaria e do ateliê, a associação tem uma parceria com o Sesc em atividades de turismo social. O maior objetivo dessas atividades é "propiciar ambientes turísticos em que as experiências culturais e humanas sejam compartilhadas, sem que as comunidades anfitriãs sejam descaracterizadas ou se tornem dependentes dos seus visitantes” (SESC, 2012). É um turismo que não tem seu foco somente no lazer, mas na cultura e na troca de experiências entre visitantes e anfitriões. A ACC recebe várias vezes por ano grupos de turistas que conhecem o Paquetá, visitam um cortiço para ver a realidade dos moradores do bairro, vão até o canteiro de obras do condomínio da ACC e fazem o trajeto de catraia até o Guarujá, tudo isso guiados por um historiador e por membros da associação, que vão apresentando a história do bairro e os desafios para transformá-lo. Além do almoço e do café da tarde na padaria "Um Só Coração", a visita se encerra com uma roda de conversa e uma apresentação de artistas do Movimento Hip-hop do Mercado. 
Figura 39: Turistas, membros da ACC e do Movimento Hip-hop do Mercado.

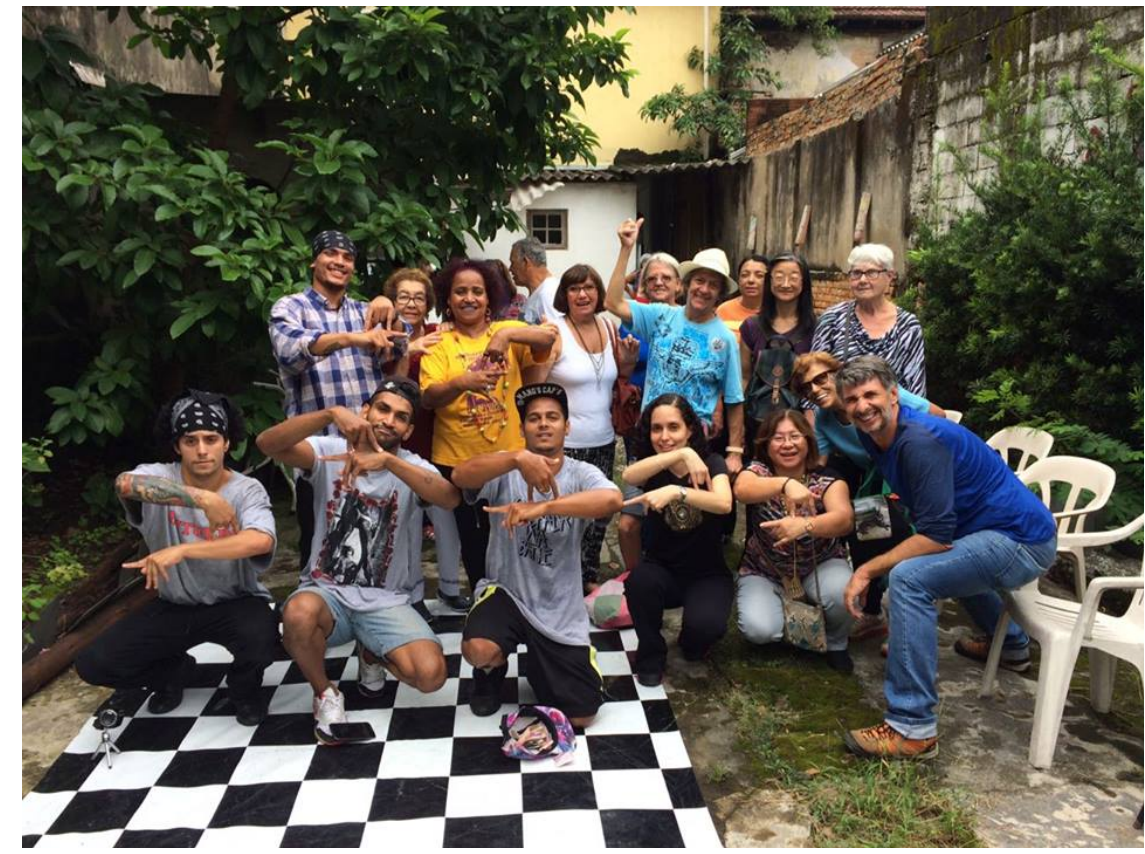

Fonte: Acervo da ACC.

As atividades de turismo social são uma forma de aumentar a receita da padaria, pois os grupos fazem lá suas refeições, e da própria ACC, pela remuneração pelo passeio e por eventuais compras de artesanato pelos visitantes. Mas também é um momento de compartilhar com outras pessoas a realidade dos moradores dos cortiços e a importância dos movimentos de moradia. A mídia hegemônica normalmente aborda movimentos de moradia como invasores, como um problema que deve ser resolvido pela força policial, e essa atividade do Sesc proporciona um contato direto com membros do movimento e permite a percepção de sua relação com o bairro, com os vizinhos.

Muitos dos visitantes não sabem antes do passeio que os moradores dos cortiços pagam aluguel e as casas não são invadidas, por exemplo. Desconhecem a realidade dessas pessoas, por que moram ali e como é a sua vida. Para a ACC, esses passeios são uma oportunidade de partilhar sua realidade, sua história e também as suas lutas e sonhos, divulgar os objetivos do movimento e a urgência da concretização do direito à moradia, que se opõe ao direito à propriedade privada, tal qual ele é na prática, inquestionável.

Para os membros do Movimento Hip-hop do Mercado ${ }^{80}$ - que são muito ligados à ACC e promovem atividades com crianças e adolescentes do bairro -, é uma oportunidade de divulgar sua arte e de arrecadar dinheiro de doações espontâneas dos visitantes.

Eu vou fazer quatro anos já aqui [na padaria], vim praqui começar a fazer

80 Um dos membros dá aulas na Fundação Casa de Praia Grande, outro em uma ONG em Santos. 
comida outra vez, vinha gente fazer marmita, comer aqui [...], agora mesmo, quando vem o Cadu [guia do Sesc], teve uma vez que veio 60 pessoas aqui, nossa, fiquei doida. Até falei, não vou servir, cada um vai pôr seu tanto que sabe que come, pra não deixar, então cada um se serve, aí fazia a fila, tem as mesas, nós coloca tudo lá fora, as panelas. Domingo vai ter outra vez, ou 28 ou 30. Aí de hoje eu já fico pensando o que que eu vou fazer, que tipo de salada eu vou fazer, quero fazer uma batata no forno, aí falei pra Nay assim, sabe o que eu vou fazer? Vou temperar o frango todinho, depois eu vou fritar ele, só no limão e no sal, depois eu vou fritar o alho e jogar tudo em cima, faz aquele frango a passarinho (depoimento de Maria de Lourdes - março de 2018).

Cada vez que vem as pessoas aqui do Cadu, encoraja mais a gente, pra responder "por que você não desistiu também?", é uma missão, né? Um compromisso. Isso que vocês tão fazendo aqui, vocês terem vindo encorajar mais a gente a não desistir, porque vocês tão dando mais credibilidade pra gente, tá dando gás pra gente, e a gente busca parceiros [...] isso mostra que é o poder do coração que tá em jogo, sei que tem o poder do dinheiro, mas eu ainda acredito no poder do coração, eu acredito no poder da fé, do coração, da união, e ação, e nós estamos fazendo ações [...] muito obrigada por trazer as pessoas pra conhecer a nossa história e dá gás (discurso de Samara Faustino no encerramento de atividade de turismo social do Sesc 18 de março de 2018).

A questão da moradia é o maior problema do bairro, a precariedade das condições de habitabilidade não mudou muito desde o século XIX: os cômodos no geral são pouco ventilados, têm paredes com umidade, portas e forros frequentemente com cupim. Outro problema muito comum é a vegetação que cresce nas paredes e no telhado das casas e pode comprometer suas estruturas (figura 38).

Figura 40: Exterior e interior de cortiços, Santos-SP.

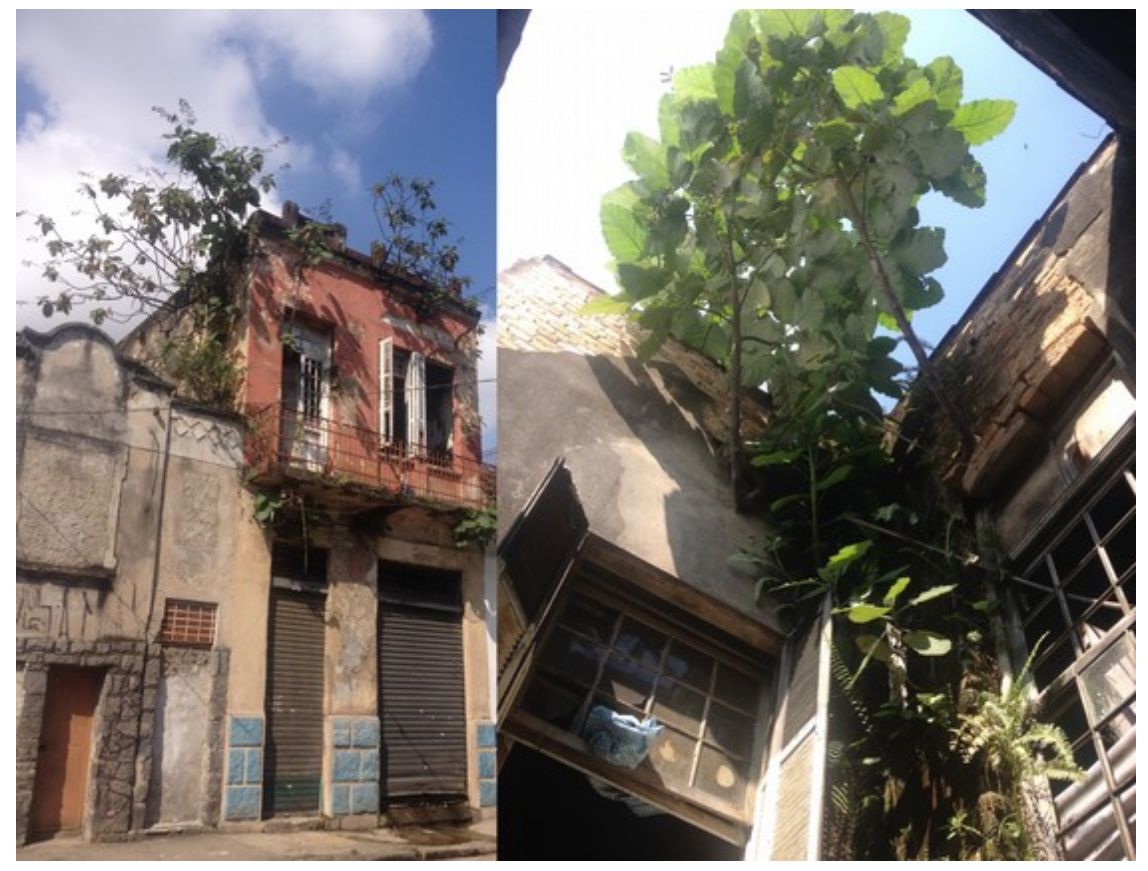

Fonte: Bruna G. Eskinazi - março de 2018. 
Os quartos de dentro da casa, nos andares de cima (quase sempre os porões também são habitados), costumam ser maiores e com janelas, mas os quartos que são construídos nos quintais, que não fazem parte da planta original, são menores, menos ventilados e onde acidentes decorrentes da instalação elétrica precária ocorrem com mais frequência. Além disso, em alguns quintais há lixo e entulho, que podem acumular água da chuva e servir como criadouros de mosquitos transmissores de doenças (figura 39). Em um cortiço situado na Rua São Francisco houve três incêndios no período de dois anos. Neste casarão, em um dos quartos construídos no quintal (figura 40), que são a possibilidade de moradia mais barata, vivia uma senhora de mais de 90 anos, cuja família não assumia a responsabilidade por seus cuidados: eram os vizinhos que faziam as suas compras e, frequentemente, a sua comida, que marcavam consultas médicas no posto de saúde e até mesmo se encarregavam de questões burocráticas, para que ela recebesse regularmente sua aposentadoria. Neste mesmo cortiço moram dois deficientes visuais, que eventualmente também precisam contar com o apoio dos vizinhos. Esses casos demonstram como existem pessoas em situação de extrema vulnerabilidade social vivendo nessas habitações, e também como as dificuldades criam relações de solidariedade muito fortes entre os vizinhos.

Tem essa coisa boa, que independente de qualquer condição as pessoas são solidárias, um ajuda o outro, sem ser sangue, sem ser nada, tem o respeito, cuida como se fosse parente. Aqui, independente das emoções, ninguém pode fazer nada de errado, tem a lei da comunidade, ninguém pode mexer nas coisas dos outros, pegar nada da casa de ninguém, ninguém chama a polícia, quem vai cobrar é o próprio sistema (depoimento de Samara Faustino março de 2018).

Figura 41: Quintal e quartos ao fundo de um cortiço, em Paquetá, Santos-SP.

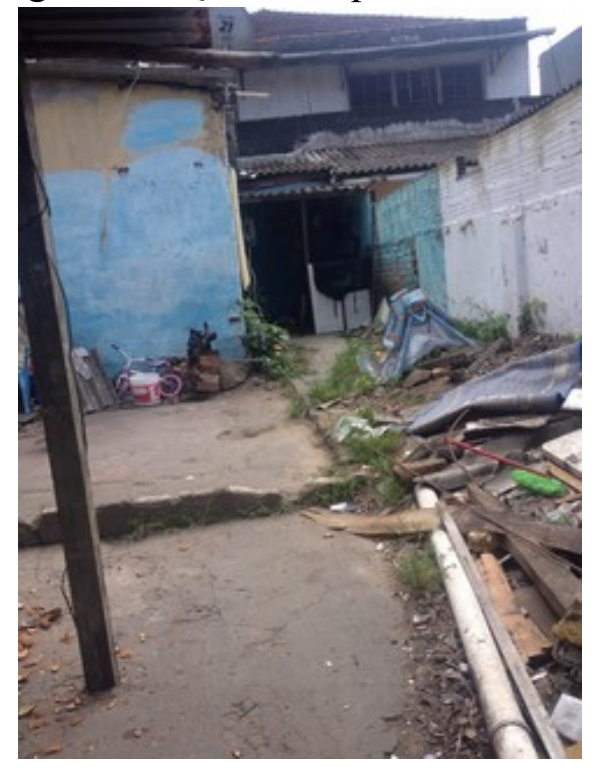

Fonte: Bruna G. Eskinazi - março de 2018. 
Neste cortiço, somente no pátio e no porão existem 8 quartos, os moradores destes e dos 5 quartos no interior da casa dividem apenas dois banheiros e um tanque de lavar roupa. Segundo o censo dos moradores de cortiços de 2003, 91\% dos banheiros e $96 \%$ dos tanques em cortiços são de uso coletivo. Além disso $57 \%$ dos fogões são de uso privado, ou seja, estão no mesmo cômodo que é usado como dormitório, aumentando risco de incêndio e de contaminação por eventuais vazamentos.

Convivendo com essa grave situação de precariedade, a ACC se articula para conquistar o seu principal objetivo: a moradia de qualidade no centro da cidade. Um processo de resistência para permanecer no centro, mas em outras condições.

Resistir é, em princípio e simplesmente, não ceder, mesmo se a situação está comprometida, mesmo se a posição é má, mesmo se estamos encurralados em um lugar de fraqueza ou impotência talvez passageira. Resistir implica reconhecer as fraquezas, admitir o equilíbrio de forças desfavorável, mas sem com este consentir, sem consentir com as fraquezas, sem as aceitar, sem aderir a elas e sem a elas se resignar (BENSAID, 2001, p. 39, tradução nossa). ${ }^{81}$

Figura 42: Interior de um quarto nos fundos de um cortiço em Paquetá, Santos-SP.

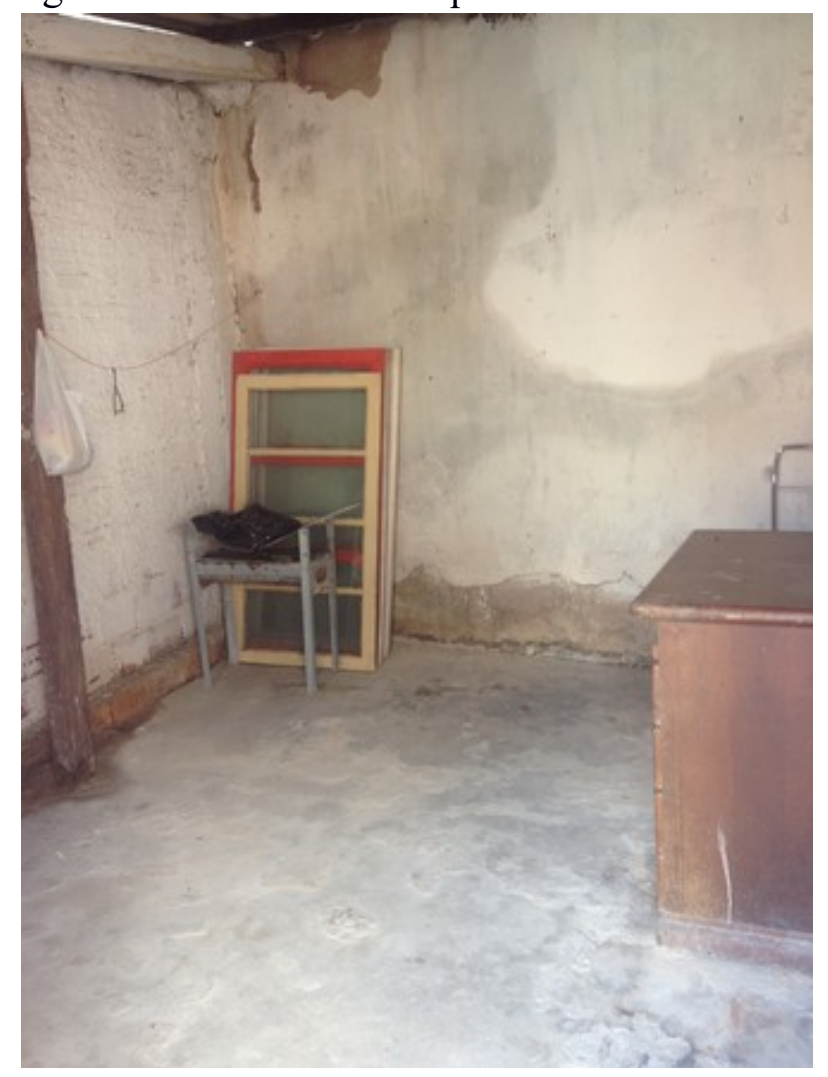

Fonte: Bruna G. Eskinazi - março de 2018.

81 Résister, c'est d'abord, et tout simplesment, ne pas céder, même si la situation est compromise, même si la posture est mauvaise, même si l'on est acculé à une position de faiblesse ou d'impuissance peut-être passagère. Résister implique de reconnaître as faiblesse, d'admettre le rapport de forces défavorable, mais sans jamais y consentir, sans consentir à as faiblesse, sans l'accepter, sans y souscrire et sans s'y résigner. 
Para perseguir seu objetivo, a ACC buscou apoio de outros movimentos de moradia, integrantes da União Nacional de Movimentos de Moradia (UNMM), do Movimento Nacional de Luta por Moradia (MNLM) e da Central de Movimentos Populares (CMP). ${ }^{82}$ Movimentos de abrangência nacional que lutam pelo direito à moradia e participam do debate sobre a reforma urbana desde suas formações em, respectivamente, 1989, 1990 e 1993.

A luta já começou há anos, pedindo habitação da CDHU e pedindo também, aí formaram comissões, fomos pra São Paulo, abriu o leque para conhecer os outros movimentos que já tinham construído em São Paulo, fazer intercâmbio, fomos em mutirões, na Juta, vários, pra gente poder se animar, pra ver que é possível. Até na Praia Grande, no sítio do campo, pra ver que o que a gente tava sonhando não era uma mentira, poderia tá fazendo algo. [...] nós levávamos ônibus, pras pessoas verem, pra se animarem também, pra não acharem que eu tava louca sozinha. Iam tudo junto, então isso foi nos dando mais ânimo e aprendendo também (depoimento de Samara Faustino - março de 2018).

A interação com outros movimentos foi fundamental no processo de aprendizagem coletiva dos membros da ACC. Participando de manifestações e reuniões com esses movimentos, a ACC conheceu o Programa Crédito Solidário do governo federal. Este programa tinha como diferencial o fato de que a entidade organizadora era a proponente da demanda para o empreendimento habitacional, ou seja, era a associação ou o movimento que definia, por meio de sua base, os futuros moradores, e também era responsável por fazer o levantamento dos documentos de cada família necessários para encaminhar à Gerência de Desenvolvimento Urbano (Gidur) da Caixa Econômica Federal, para pleitear recursos do Fundo de Desenvolvimento Social. Esses recursos poderiam ser usados de quatro maneiras diferentes: aquisição de material de construção, aquisição de terreno e construção, construção em terreno próprio e conclusão, ampliação ou reforma de unidade habitacional. A associação que não tivesse terreno próprio, além da proposta do empreendimento, deveria incluir na documentação o compromisso de compra e venda com o proprietário. Para todas as etapas do programa, até a fase de ocupação, as associações podiam ter apoio de assessorias técnicas (MOREIRA, 2009).

O programa foi aprovado em abril de 2004 e em 2005 financiava até $\mathrm{R} \$ 25$ mil $^{83}$ por unidade habitacional do empreendimento, sendo que dois anos depois o valor foi reajustado para até $\mathrm{R} \$ 30$ mil. ${ }^{84} \mathrm{O}$ diferencial para a ACC é que não houve necessidade de aquisição de terreno, o

82 Dentre os três movimentos, a CMP tem pautas mais amplas do que o direito à moradia, e engloba movimentos sociais feministas, negros, LGBT e por saúde e direitos humanos.

83 US\$ 10.464,63 (R\$ 28.476,26 em março de 2018).

84 US\$ 15.762,10 (R\$ 56.389,68 em março de 2018). 
que encareceria muito a obra em uma cidade como Santos.

A realidade nossa é aqui, a luta é aqui, pessoal já vem de família, tem escola, trabalha tudo aqui, e lá sai mais caro porque tem que ter dinheiro pra condução. Aqui é uma cidade boa, gostosa, pequena, a pessoa bota uma rodinha no pé, anda tudo aqui de graça, pra tudo quanto é lugar. O pessoal ajudou a construir isso aqui também, crescemos, se mobilizamos, as pessoas participaram também (depoimento de Samara Faustino - março de 2018).

A associação encontrou um terreno de $6,5 \mathrm{mil} \mathrm{m}^{2}$ pertencente à União que estava abandonado há muitos anos e fez o contato com o escritório da Secretaria do Patrimônio da União em Santos, que por sua vez encaminhou o pedido de doação do terreno para a Superintendência do Patrimônio da União em São Paulo. Este órgão requisitou à ACC que se fizesse uma mudança no perímetro da Zeis 3 na legislação municipal de Santos, para que houvesse uma justificativa da doação do terreno para HIS; nesse momento o perímetro da Zeis 3 estava a apenas 200 metros do terreno, situado na esquina das Ruas General Câmara e dos Estivadores.

Depois nós aprendemos que tinha que ser Zeis, né? Aí tivemos novamente que ir na Prefeitura, na Câmara, encher o plenário, colocar bandeira, levar o povo todo, porque eles não queria que fosse Zeis, os vereadores. Aí, quando eles viram a multidão do cortiço, que eles nunca viram, encher o plenário, com bandeira [...] ficaram tudo assim em choque. Já tínhamos pedido pra um vereador votar, como é que nós pedimos pra um vereador? Numa assembleia teve vários vereadores, tem os mal e os menos mal... na época era o Fabião [Fabio Alexandre de Araújo Nunes], foi ele que votou pra que fosse utilidade pública, ele que colocou a pauta lá pra gente (depoimento de Samara Faustino - março de 2018) ${ }^{85}$

A partir dessa doação, que segundo a ACC foi a primeira doação de terreno da União para construção de moradias de interesse social, foi criada a Lei n ${ }^{0} 11.481$, de 31 de maio de 2007, que facilitava a doação de imóveis da União para fins de habitação social. ${ }^{86}$ Somente com a doação do terreno ${ }^{87}$ seria possível a construção dos condomínios Vanguarda I e II da ACC no centro de Santos, pois com o valor do financiamento não seria possível adquirir um terreno em uma área tão valorizada da cidade.

Depois de formalizada a doação do terreno, a ACC enfrentou um empecilho para conseguir

85 A alteração do perímetro da Zeis 3 foi aprovada pela Câmara Municipal em 12 de dezembro de 2008 e sancionada no dia 30 do mesmo mês pela Lei Complementar $n^{\circ} 646$.

86 “Art. 31. Mediante ato do Poder Executivo e a seu critério, poderá ser autorizada a doação de bens imóveis de domínio da União, observado o disposto no art. 23 desta Lei, a: V - beneficiários, pessoas físicas ou jurídicas, de programas de provisão habitacional ou de regularização fundiária de interesse social desenvolvidos por órgãos ou entidades da administração pública, para cuja execução seja efetivada a doação."

87 A ACC chegou a receber propostas do proprietário do terreno vizinho à área em que seria construído o condomínio, de permuta por um terreno maior no bairro Valongo. Seu interesse era expandir a área de armazenamento de contêineres. 
realizar o contrato do PCS, já que havia uma dívida prévia do imóvel, de R\$150 mil, com a Prefeitura de Santos, pela taxa do lixo.

Não tinha lixo nenhum, mas essa coisa gerada pela Prefeitura. E a gente não poderia tá fazendo nada se não viesse a certidão negativa, aí houve uma reunião com a associação, a assessoria, a comunidade, a Caixa, a SPU e a Prefeitura e nessa reunião o secretário falou na pessoa do prefeito, que era o Márcio Lara [secretário de Desenvolvimento e Assuntos Estratégicos de Santos na gestão 2009-2012], ele falou o seguinte, que iria dar essa certidão na semana tal, e que eles falaram que era a mais próxima que tinha, que não tinha nada contra, eles apoiavam essa luta da comunidade... mas quando nós fomos buscar, ele deu uma carta de apoio (depoimento de Samara Faustino março de 2018).

Com a demora do poder municipal em liberar a certidão negativa do imóvel houve uma pressão do Ministério das Cidades para que a Prefeitura isentasse a associação dessa taxa e o contrato pudesse ser firmado. Em 2008 foi expedida a certidão negativa do imóvel e em novembro do mesmo ano o contrato com a Caixa foi firmado.

As entidades em todo o país tiveram muita dificuldade em ter os projetos de seus empreendimentos aprovados, havia vários empecilhos, desde o levantamento da documentação de toda a demanda e do terreno até o projeto em si, que deveria ser aprovado pelas gerências da Caixa. Somente as entidades muito bem organizadas e com boas assessorias conseguiram a aprovação de seus projetos e apenas 158 contratos foram firmados entre 2005 e 2007.

Em novembro de 2007, na $3^{\text {a }}$ Conferência das Cidades, ${ }^{88}$ por pressão dos movimentos de moradia, novas normas foram definidas e foi lançado no início do ano seguinte o Programa Crédito Solidário 2. Entre 2005 e 2011, o PCS contratou mais de 20 mil unidades habitacionais - das quais quase $40 \%$ foram contratadas no ano de 2008 , com as novas regras que facilitaram a aprovação dos projetos (MINEIRO; RODRIGUES, 2012).

Os membros da ACC se reuniram em assembleias para definir como seria o projeto do Vanguarda I e como seriam as regras para uma pessoa ser incluída na demanda, e optaram pelo mutirão para reduzir o valor da obra. Decidiram que o prédio de 113 apartamentos teria 4 tipologias distintas: sala living, 1, 2 e 3 dormitórios, sendo que os apartamentos do térreo seriam acessíveis para cadeirantes. O preço é o mesmo para as quatro tipologias, o que difere

88 Em 2003, a $1^{\text {a }}$ Conferência Nacional das Cidades (precedida por conferências em mais de 3 mil municípios e em todos os Estados da Federação) implementou o Conselho das Cidades, órgão colegiado integrante do Ministério das Cidades, e criou diretrizes para políticas de habitação social (criação do Fundo Nacional de Habitação de Interesse Social), mobilidade urbana, saneamento básico, etc. $\mathrm{Na} 3^{\text {a }}$ edição da conferência, houve avanço na disponibilização de recursos para a habitação por meio de entidades autogestionárias e também no comprometimento da União de ceder seus imóveis ociosos para construção de HIS. 
são as horas de mutirão, que são proporcionais ao tamanho do apartamento, variando de 8 a 16 horas semanais. Para se manter na demanda do empreendimento, as famílias deviam cumprir as horas de mutirão e ter presença nas assembleias.

\begin{abstract}
Aí, depois que foi feita a fundação do prédio, aí fizemos, o arquiteto fez lá um lugar pra nós fazer comida, aí comecei a fazer comida pro pessoal da obra, e começou a vender também pra fora. Aí lá eu trabalhava com, só de fora era 400 pessoas, fora os da obra, porque os da obra comia lá também. [...] Os de fora era trabalhador de firma, as crianças da rua, tudo ia comer lá, aí depois comecei a fazer o café, eu e uma colega minha, essa mora lá no morro. Nós começamos com esse trabalho 4 horas da manhã, pra quando o pessoal da obra chegasse estava pronto, e eles chegavam às 6 horas pra ir pro trabalho às 6 e meia, aí eles já tinham que tomar aquele café lá. Aí, quando eles tomava aquele café, eu já tinha que ir lá fazer aquela comida lá. Quando dava 11 horas já começava a loucura da comida. Nós ficava até 6 horas, 7 horas da noite, servindo comida ainda.[...]

Menina, quando nós fomos pra esse terreno não tinha banheiro, não tinha nada, nem água tinha, eu pegava água lá do bar da esquina. Depois que fez a fundação, nós fomos na Sabesp e pedimos água, e ligaram a luz também. Aí foi feito o banheiro, foi feito a minha cozinha lá. Tinha os quartos de guardar os capacetes. Até hoje eu tenho meus capacetes guardado, só entrava lá de capacete. Eu acho que ninguém tem, eu tenho (depoimento de Maria de Lourdes - março de 2018).
\end{abstract}

A ONG Ambienta - Assessoria e Desenvolvimento Local ${ }^{89}$ desenvolveu o projeto a partir das preferências dos beneficiários e dos limites para projetos de habitação social. "Janelas, primeira prioridade das famílias quando tavam escrevendo o projeto. Eles perguntaram 'qual é a prioridade de vocês?' - Janela, porque no cortiço não tem janela, é um quartinho fechado mesmo." (depoimento de Nay Faustino - março de 2018). Segundo pesquisa realizada em 2001 pela Fundação Seade, encomendada pela CDHU, em 33\% dos domicílios em cortiços não havia janela para o exterior e quase $90 \%$ dividiam banheiro com os vizinhos. Os apartamentos do Vanguarda I têm janelas amplas e também banheiros com a pia do lado de fora do cômodo, assim uma pessoa pode usá-la mesmo se o banheiro estiver ocupado, situação muito diferente das grandes filas do banheiro nos cortiços. Um dos elementos inovadores do projeto foi o apartamento de três dormitórios, pois o padrão para habitação social (desde o $\mathrm{BNH}$ ) costuma ser dois dormitórios, o que frequentemente exclui famílias muito numerosas e também as de duas pessoas, ou pessoas que vivem sozinhas. Essa particularidade do projeto tornou-se motivo de desacordo com a Prefeitura de Santos, que exigia, para que fosse dada a contrapartida municipal (já aprovada pela Câmara de

89 ONG de assessoria arquitetônica a movimentos de moradia, responsável pelo projeto de um empreendimento MCMV-E em Praia Grande-SP. A ONG não respondeu aos contatos para disponibilizar mais informações. 
Vereadores) de $\mathrm{R} \$ 1,2$ milhão, ${ }^{90}$ que não houvesse a tipologia de três dormitórios. A Prefeitura não tinha interesse em criar um precedente e lidar com demandas futuras de apartamentos com três dormitórios nos empreendimentos habitacionais municipais.

Aí foi legal a participação, vocês tão vendo o baldrame, a parte de baixo, nós não quisemos que nem de CDHU, que eles são bem baixos, esse é o térreo, eles são bem baixos, quem mora não tem privacidade pra fritar um ovo, pra dormir, pra ficar à vontade, não tem privacidade. Então, com a participação da comunidade, os arquitetos fizeram como a comunidade queria, com área de lazer, com separação do lixo limpo e orgânico, com box comunitário, porque houve a participação e eles botaram tudo do jeito como a gente queria $[\ldots]$.

E outra coisa que o pessoal gostou muito é que sai no nome das mulheres, elas que decidem se quer que fique no nome do homem ou não. A prioridade é no nome das mulheres. De $100 \%, 90 \%$ são mulheres, tem marido, tem namorado, mas daqui a pouco eles vão viajar e some, deixa a família, elas que segura a onda, chefe de família mesmo (depoimento de Samara Faustino - março de 2018).

Em 2009, a ACC recebeu o prêmio "Melhores práticas em gestão local” da Caixa pelo projeto do Vanguarda I, concorrendo com mais de 300 inscritos em todo o Brasil, e ganhou R\$25 mil na premiação. Segundo a ACC, a intenção era usar os recursos para construir o parquinho das crianças, assim que o condomínio estivesse finalizado. No entanto, a Caixa não permitiu que os recursos fossem guardados. O parquinho foi construído, mas terá que passar por uma reforma porque se deteriorou um pouco com o tempo.

A ACC também concorreu a um prêmio internacional, o World Habitat Awards, ${ }^{91}$ que anualmente premia duas iniciativas na área de habitação social com o valor de $£ 10.000$. A associação ficou entre os dez finalistas na edição de 2013.

As obras do PCS são feitas em medições: a Caixa libera duas parcelas da verba e, ao verificar que a primeira medição foi cumprida, libera a terceira parcela, e assim sucessivamente. Segundo a ACC, em 2010, cerca de 60\% das obras do Vanguarda I estavam concluídas quando a construtora R3S Engenharia e Construções, alegando que a verba era insuficiente para concluir aquela medição, abandonou as obras. A construtora, que fora indicada pela Caixa para a ACC, recebeu o valor da medição, mas não executou o trabalho, desfalcando a associação em cerca de R $\$ 180$ mil.

90 US\$ 748.083,00 (R\$ 1.988.382,60 em março de 2018).

$91<$ https://www.world-habitat.org/world-habitat-awards/winners-and-finalists/the-struggle-for-housing-incentral-areas/> 
Figura 43: Projeto dos condomínios Vanguarda I e II em Santos-SP.

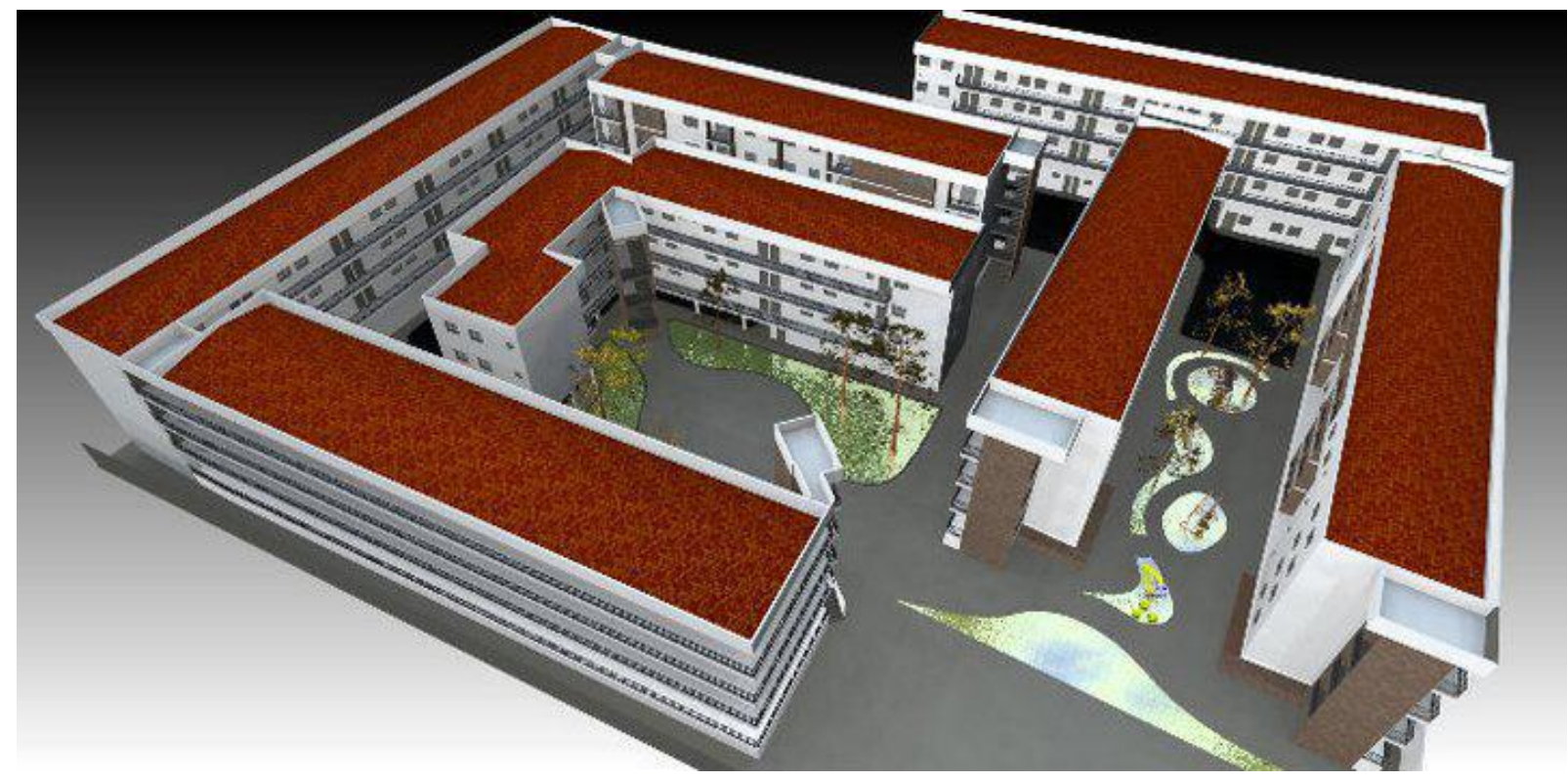

Fonte: Acervo da ACC.

Figura 44: Obras do condomínio Vanguarda I em Santos-SP.

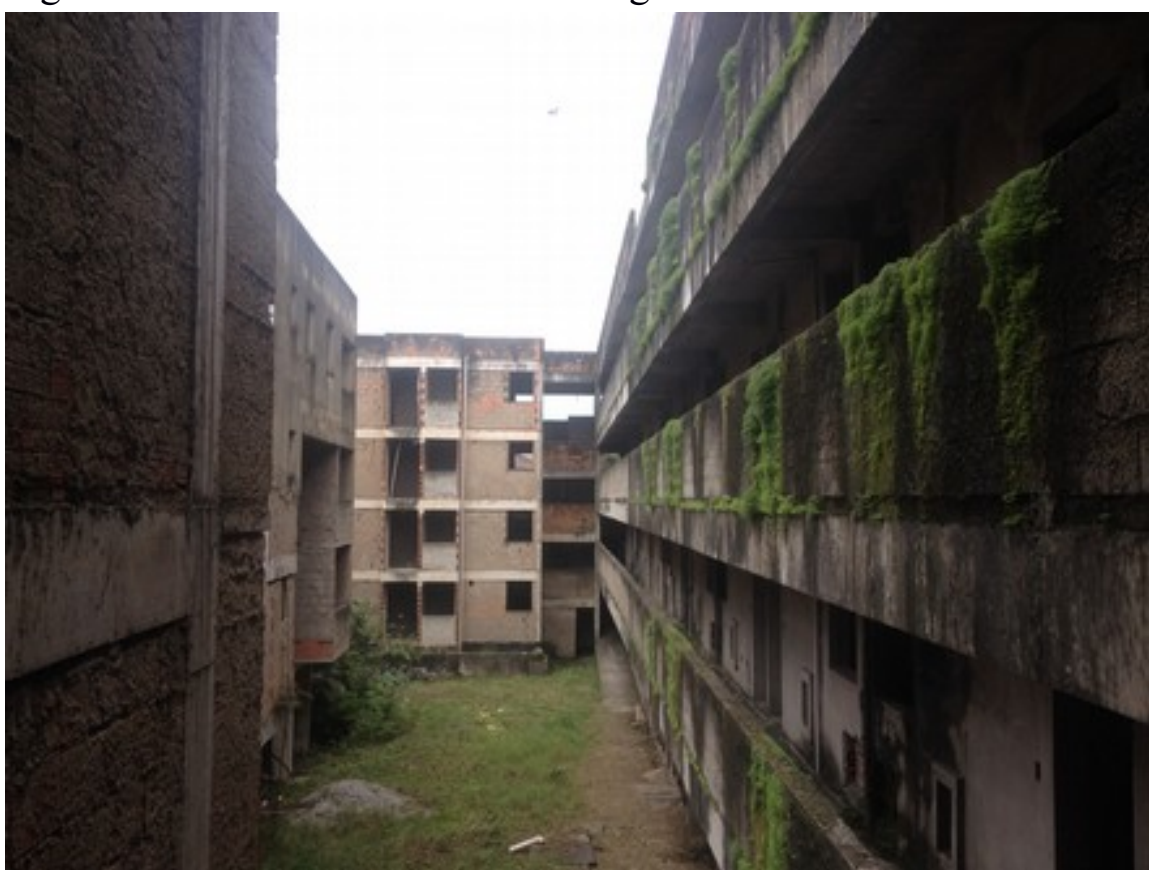

Fonte: Bruna G. Eskinazi - março de 2018.

A ACC contratou um advogado para resolver as pendências com a Caixa, que naquele momento não abriu uma investigação. A Caixa e a ACC chegaram a um acordo para que as próximas parcelas da verba fossem liberadas subtraindo o dinheiro que a construtora recebera sem ter entregue a obra correspondente. Dessa forma, para cumprir cada meta da construção o orçamento já estaria um pouco defasado, mesmo sem considerar perdas decorrentes da 
inflação. "[A construtora] que sumiu com uma medição nossa, cerca de R $\$ 180$ mil, e depois nós pegamos em autogestão mesmo, sem a construtora, com a assessoria, que a assessoria depois também tive um problema com eles, muitas emoções" (depoimento de Samara Faustino - março de 2018). Em julho de 2012, a Caixa suspendeu os pagamentos até que fosse esclarecido o problema com a verba paga à R3S. A ACC está ainda com um processo na Justiça contra a R3S. Algum tempo depois a Ambienta se desligou do projeto.

O Condomínio Vanguarda não é uma exceção entre os empreendimentos do PCS, outros 56 estão com obras paradas em todo o país (cerca de 6 mil UHs), e um dos motivos é a demora entre a elaboração dos projetos e o início das obras por causa de todos os requisitos da Caixa. Assim, com a inflação as obras já começam com orçamentos defasados. Em fevereiro de 2016, o Ministério das Cidades publicou uma declaração de que distribuiria verbas (R\$ 81,4 milhões $^{92}$ ) do Fundo de Desenvolvimento Social para concluir os empreendimentos do PCS. No entanto, antes que fosse publicada uma normativa com as regras para pleitear esses recursos, ocorreu o afastamento do mandato da presidente Dilma Rousseff, que em seguida sofreu um golpe e foi deposta. O governo interino não deu sequência ao processo e a normativa não saiu naquele momento.

Porque assim mudou a gestão, projeto da Dilma e do Lula eles querem podar tudo, é uma briga política e nós estamos no meio dessa briga, porque nossos projetos, tanto os outros de São Paulo como de outros locais, vêm deles dois, então estamos sofrendo as consequências. Mesmo tendo dinheiro, recurso na Caixa, eles não falam que não. Falam: "Então vocês trazem o projeto atualizado, as propostas, o orçamento." Mas o nosso orçamento tá defasado, ele é de 2007, começou em 2009. Já era dois anos atrasado, de lá pra cá mais ainda. E não tem dinheiro para trabalhos que já foram feitos. E o cimento naquela época era $\mathrm{R} \$ 9,00$, a mão de obra aumentou, tudo aumentou (depoimento de Samara Faustino - março de 2018).

A descontinuidade de políticas públicas é bastante comum em mudanças de gestões no Brasil, mas foi mais acentuada no golpe de 2016, com significativos cortes orçamentários em áreas sociais. No caso da prolongada paralisação de obras os cofres públicos frequentemente são duplamente onerados, porque é necessário refazer trabalhos que foram deteriorados com o tempo.

Paralelamente a esse primeiro prédio de 113 apartamentos, a ACC conseguiu o financiamento do segundo prédio (no mesmo terreno), com 68 apartamentos, em 2011, pelo Programa Minha Casa Minha Vida - Entidades. Por causa do problema com a construtora R3S, no entanto, a Caixa também interrompeu os pagamentos desse segundo empreendimento, que só tem a

92 US\$ 20.525.976,00 (R\$ 85.034.872,00 em março de 2018). 
fundação terminada.

O Programa Minha Casa Minha Vida foi criado em março de 2009 e abarcava financiamentos para três diferentes faixas de renda (de 0 a 3 salários-mínimos, de 3 a 6 salários-mínimos e de 6 a 10 salários-mínimos), com subsídios de 70\% a 90\% para a construção dos imóveis da menor faixa de renda. O programa tinha a ambiciosa meta de construção de 1 milhão de casas, que foi superada em 2010.

A proposta inicial do Minha Casa Minha Vida contemplava somente contratos diretos com as famílias, sem a intermediação de associações ou movimentos. Com a reivindicação dos movimentos sociais de moradia de que parte da produção habitacional fosse realizada por meio de autogestão, em 10 de junho de 2009 foi criado o Minha Casa Minha Vida - Entidades (Resolução do Conselho Curador do FDS no 141). Este programa, assim como o PCS, utiliza recursos do FDS, que são transferidos do Orçamento-Geral da União. O MCMV-E tem subsídios para o financiamento e o pagamento das parcelas é de $10 \%$ da renda mensal familiar, por 10 anos. Diferentemente do PCS, em que a família paga o valor integral do imóvel em parcelas mensais, em até 20 anos. A maior dificuldade das associações e movimentos é, assim como no PCS, a compra do terreno. Com o mercado de terras bastante aquecido desde o lançamento do MCMV, as entidades disputam terras diretamente com as grandes construtoras, que procuram adquirir terrenos para um banco de terras, mesmo antes de terem empreendimentos aprovados. Dessa forma, nas regiões metropolitanas os terrenos possíveis de serem adquiridos pelas entidades se localizam nas franjas urbanas, reproduzindo a lógica da segregação socioespacial.

A competição no mercado de terras em condições desiguais provoca o fechamento das áreas urbanizadas ao acesso dos movimentos sociais. Esse fenômeno é explicado, em boa parte, pelo fato de a liberação dos vultosos recursos públicos para a provisão da moradia não vir acompanhada de uma política municipal de reserva de terras urbanizadas para habitação popular, condição para o efetivo planejamento e controle, pelo poder público, da expansão urbana e das práticas especulativas sobre o solo urbano. $\mathrm{Na}$ ausência desse controle, áreas com algum grau de urbanização passam a ser disputadas por empresas construtoras com capacidade de acumular grande estoque de terras (LAGO, 2012, p. 188-9).

Tanto na criação do PCS quanto na das duas modalidades do MCMV, o governo federal renunciou ao planejamento de onde seriam construídas as moradias; a ausência total de uma política fundiária favoreceu quem já fazia especulação imobiliária com terrenos vazios, política necessária para reduzir desigualdades sociais tão acentuadas como no Brasil. No caso da maioria dos empreendimentos do MCMV realizados por construtoras, elas decidiam 
construir não onde houvesse maior demanda, mas onde os terrenos fossem mais baratos e a lucratividade, portanto, maior. Assim, as regiões metropolitanas, com maior demanda e terrenos mais caros, tiveram, proporcionalmente, menos construções do que cidades não pertencentes a regiões metropolitanas, com terrenos mais baratos.

Nas regiões metropolitanas, houve um aumento do deficit habitacional absoluto entre os anos de 2007 e 2012 e também um aumento de famílias com ônus excessivo no aluguel. No entanto, no país como um todo o deficit diminuiu no período, de 6,107 milhões de unidades habitacionais para 5,792 milhões (RIZEK, 2017).

Os movimentos de moradia que conseguem realizar seus empreendimentos habitacionais nas franjas urbanas têm que lutar, após a conquista da habitação, pelas infraestruturas urbanas, como creches, postos de saúde, linhas de ônibus, etc. Esse ideal de bairro popular está mais consolidado nos movimentos de moradia mais antigos; na Grande São Paulo, em que existem movimentos com mais de 30 anos, essas demandas já estão associadas à moradia (LAGO, 2012).

Segundo Lago (2012), houve grande pressão das construtoras para aumentar o valor por UH, e existem alguns empreendimentos do MCMV em que as famílias fazem duplo financiamento, um com a Caixa e outro com a construtora - em um caso no Rio de Janeiro, cada UH chega ao valor de R $\$ 78$ mil. Assim, as construtoras conseguem um sobrelucro e, ao mesmo tempo, ao culpabilizar o alto valor da terra pelos custos, pressionam a Caixa para aumentar os valores financiados, escondendo que são as próprias construtoras que geram a valorização imobiliária com suas práticas especulativas.

Nos financiamentos do Programa Minha Casa Minha Vida - Entidades, assim como no PCS, associações, cooperativas e movimentos levantam uma demanda de famílias que tenham rendimentos de até R\$ $1.600,00$, são responsáveis pela documentação dessas famílias, por buscar o terreno, pela contratação de assessoria técnica para a elaboração do projeto e pelo acompanhamento de toda a obra. Mas, como vantagem em relação ao PCS, o MCMV Entidades também tem as obras parcialmente subsidiadas pelo governo federal. Na primeira fase do MCMV, a meta era de que as obras contratadas na modalidade Entidades correspondessem a 3\% do total do programa, mas elas só chegaram a menos de $1 \%$ e há uma quantidade bem expressiva de projetos não concluídos.

Os integrantes da ACC compareceram a um curso ministrado pelos técnicos da Gidur para esclarecer às entidades os procedimentos e regras necessários para pleitear os recursos do 
MCMV - Entidades. A ACC conseguiu a contratação do projeto, o primeiro da modalidade no Brasil, em janeiro de 2010 - o Vanguarda II, com apartamentos de 1, 2 e 3 dormitórios. No entanto, as obras não avançaram muito, somente a fundação foi finalizada, pois no ano seguinte, por causa do problema com a construtora R3S, a verba foi congelada pela Caixa.

A maior dificuldade dos membros da associação para finalizar a obra é a ausência de ligação de água e esgoto do prédio. No início de 2016, a assessoria técnica Peabiru fez um levantamento ${ }^{93}$ de tudo o que faltava ser feito na obra, incluindo o que precisava ser refeito porque se deteriorou com o tempo, e elaborou um orçamento com valores atualizados. Eram necessários para o término das obras do Vanguarda I R 4,5 milhões, e ainda existia $\mathrm{R} \$ 1,5$ milhão na Caixa, referente aos recursos iniciais, que não foram liberados pelo problema com a construtora. Mas, com a falta da normativa para liberação da verba, as obras continuavam paradas. Somente em 14 de março de 2018 foram publicadas no Diário Oficial da União (seção I, p. 57-60) $)^{94}$ as diretrizes para a conclusão dos empreendimentos paralisados do PCS em todo o Brasil. A resolução determina os reajustes de valores por UHs (respeitando a proporcionalidade do que já foi realizado da obra), segundo a tabela de reajuste por localidade; na Baixada Santista os empreendimentos têm o valor reajustado de R $\$ 30$ mil por UH para até R\$ 83 mil por UH. A previsão da ACC e da assessoria técnica é de que as obras possam ser retomadas no segundo semestre de 2018, em empreitada global, sem mutirão.

A partir daí, o cadastro das famílias está sob revisão, para retirar da demanda do Vanguarda I aqueles que não têm mais interesse no financiamento, os que faleceram e não deixaram herdeiros e as pessoas que não frequentaram o mutirão nem as reuniões, e substituí-los pelas famílias da lista de espera.

93 Este foi o segundo levantamento feito pela Peabiru para a ACC, pois já fizera um primeiro em 2013.

94 Art. $1^{\circ} \mathrm{O}$ Fundo de Desenvolvimento Social (FDS), observados os princípios da legalidade, finalidade, razoabilidade, moralidade administrativa, interesse público e eficiência, fica autorizado a assumir despesas com a retomada, legalização e conclusão de obras, contratadas no âmbito do Programa Crédito Solidário (PCS), cuja execução encontre-se paralisada, a partir de identificação em laudo de vistoria e em parecer técnico de engenharia, ambos emitidos pelo Agente Financeiro.

Art. $2^{\circ}$ Fica autorizada a destinação de recursos do FDS, no montante de R \$ 81.485.935,60 (oitenta e um milhões, quatrocentos e oitenta e cinco mil, novecentos e trinta e cinco reais e sessenta centavos), para custeio das despesas com retomada, legalização e conclusão das obras paralisadas, contratadas no âmbito do PCS.

$\S 1^{\circ}$ Os recursos de que trata o caput são os provenientes da Conta Subsídios, criada pela Resolução CCFDS n ${ }^{\circ}$ 209, de 16 de dezembro de 2015, e deverão ser segregados em conta Custeio de Retomada de Obras a ser criada, especificamente, para cobertura das despesas com retomada, legalização e conclusão de obras paralisadas no âmbito do PCS. [...]

Art. $3^{\circ}$ Os recursos aportados pelo FDS para pagamento de despesas com a retomada, legalização e conclusão das obras do PCS, que excederem o valor original contratado, não comporão o valor de financiamento habitacional contratado e serão destinados, exclusivamente, à retomada, legalização e conclusão das 56 (cinquenta e seis) operações relacionadas no anexo I. 
Tem muita gente cadastrada, até teve uma assembleia mês passado, tinha advogado, aí o pessoal falou tudo o nome de quem morreu, aí falou "tá parecendo um velório aqui”. Já 30 ou 40 pessoas já saiu. Aí nós não sabe se tem algum herdeiro, ninguém sabe. [...] Tem gente que tá velhinha já. [...] e ela tem esperança de ter o apartamento dela, eu falei "vai na tua fé". Que a gente tem que ir na fé, não é? Agora, não sei como vai ficar isso aí, porque tem que fazer novos cadastros outra vez. Como tá há muito tempo, tem que fazer outro cadastro (depoimento de Maria de Lourdes - março de 2018).

Esse caso demonstra como há um descompasso entre o tempo da vida das pessoas que necessitam de moradia e a realização das políticas públicas. Existem pessoas que mudaram de cidade, ou que assinaram contratos para apartamentos pequenos porque na época eram solteiras e agora, com famílias maiores querem mudar o contrato para adquirir um apartamento de dois ou três dormitórios.

Em todo o período que a obra ficou paralisada houve desmotivação das famílias e muitas deixaram de frequentar as reuniões. A ACC tentou buscar recursos junto à CDHU e à Prefeitura de Santos, mas em todas as vezes, segundo a assessoria técnica Peabiru, um órgão passava a responsabilidade para o outro, dizendo que liberaria recursos se a Caixa liberasse o montante que estava congelado primeiro. Já a Caixa dizia que só liberaria os recursos quando a ACC comprovasse que tinha o restante do valor para terminar a obra.

A ACC participou de várias reuniões com técnicos da Gidur para tentar retomar as obras do condomínio, mas desde 2016, com o golpe, houve uma mudança do corpo de funcionários da gerência da Baixada Santista e o diálogo se tornou mais difícil. Os membros da associação também participaram, com integrantes de outros movimentos sociais, de manifestações e acampamentos que reivindicavam moradia, como o acampamento em frente ao Palácio dos Bandeirantes (sede do governo do Estado de São Paulo) em novembro de 2015, que exigia que o governador cumprisse a promessa de construção de 10 mil unidades habitacionais por meio de autogestão. O acampamento, que durou 19 dias, também demandava a destinação de terra pelo governo estadual para empreendimentos do MCMV - Entidades, o fim de remoções decorrentes das obras do Rodoanel e do Monotrilho e a posse do Conselho Estadual das Cidades. Entre as várias manifestações, estiveram na de 8 de novembro de 2017, na frente da sede da Presidência da República em São Paulo, quando o governo federal anunciou que o MCMV teria seu orçamento zerado para o ano de 2018. Em 18 de janeiro de 2018, na inauguração do condomínio Dandara do MCMV - Entidades, no centro de São Paulo, membros da ACC foram pressionar o ministro das Cidades, Alexandre Baldy (sem partido), a liberar os recursos das obras do PCS paradas em todo o Brasil. 
A luta pela moradia digna ganha outros significados quando consideramos que "o sentido do termo habitar está na base da construção do sentido da vida, nos modos de apropriação dos lugares a partir da casa, no emaranhado dos lugares comuns, habitados, usados por sujeitos comuns, na vida cotidiana" (CARLOS, 2015, p. 56, itálico do autor). Dessa forma, a luta pela moradia (lugar primeiro de reprodução da vida e da criação das identidades) ganha a dimensão da luta por uma vida digna, na qual os direitos sociais básicos estão garantidos.

Paralelamente à relação da ACC com movimentos nacionais de luta por moradia, seus integrantes também estabeleciam parcerias com movimentos locais, menos organizados, na cidade de Santos. Como a Associação Habitacional Vila Sapo (AHVS), criada em 2009, por moradores da Vila Sapo, favela localizada na Ponta da Praia (ver figura 1), região bastante valorizada de Santos, próxima à orla e vizinha ao porto. A favela está circunscrita em Zeis $1 \mathrm{e}$ rodeada de edifícios de alto padrão; A Zeis abarca a área da favela e um terreno sem construções, sendo que ambos pertenciam à União.

A partir da troca de experiências entre os moradores da Vila Sapo e os membros da ACC, a AHVS conseguiu a doação do terreno vazio da União para a construção de unidades habitacionais em 2011. A associação, que conta com a assessoria técnica da Peabiru, ainda não teve seu empreendimento aprovado, mas já realizou o cadastro de todas as famílias e os estudos de viabilidade ambiental. A luta da associação da Vila Sapo é similar à da ACC, seus integrantes reivindicam uma moradia de qualidade no mesmo lugar em que vivem atualmente, pois estão em um bairro com uma escola estadual e duas escolas municipais, centro esportivo, posto de saúde e de fácil acesso ao centro e aos bairros da orla.

Essa parceria demonstra que os membros da ACC têm uma preocupação que vai além da conquista da casa própria, têm um ideal de cidade e de sociedade em que a cooperação e a solidariedade são valores fundamentais; eles entendem que não se transforma a sociedade sozinhos, aprender a construir uma alternativa se torna tão importante quanto ensinar e compartilhar a experiência. "Quando tu passa a ensinar, vai ensinar outros e fala 'olha tá acontecendo isso e isso', eles não gostam que a gente sai falando a verdade, que a informação e a determinação faz as coisas mudarem" (depoimento de Samara - março de 2018).

As resistências e as insubmissões são sempre movidas por uma questão de dignidade. Elas nascem da indignação, sempre renascente e sempre renovada, jamais cansada e jamais indiferente, que impõe "fazer frente às afrontas"; da indignação da qual se alimentam as virtudes racionais da firmeza, da confiança e da perseverança. Da coragem também. A coragem, rara e banal, às vezes, de ir contra; a coragem faz levantar aqueles que 
sentem que foram ofendidos em sua dignidade, que sofreram não somente uma derrota, mas um desprezo (BENSAID, 2001, p. 40, tradução nossa) ${ }^{95}$

A resistência para Bensaid é sobretudo um ato de conservação, quase instintivo, que pode estar ligado a um sonho utópico, mas está sempre ancorado no presente. É da opressão presente e das injustiças concretas que ela nasce, possuindo uma temporalidade própria; ela nem sempre parece direta, pode ter desvios para chegar ao seu objetivo, como se tateasse seus passos a cada momento, a cada situação.

Assim são os percursos dos movimentos sociais na luta pelo direito à cidade, com avanços e retrocessos, momentos em que a conjuntura política (nacional e local) é favorável, e outros em que nem tanto, alianças que reverberam ideias, estratégias e conquistas, mas também cisões que os fazem repensar caminhos. Os momentos de conflito e as conquistas, como ter o financiamento do projeto aprovado, ou as moradias entregues, parecem ser os grandes avanços, mas, na verdade, o processo se dá no cotidiano, nas reuniões e assembleias, na busca de porta em porta pelos documentos para o envio do projeto, no aprendizado da burocracia à linguagem arquitetônica, na procura do consenso entre os membros, em buscar ajuda para aprender o processo e em oferecer ajuda na luta do outro, nas ações banais do dia a dia que constroem as relações de solidariedade.

A desigualdade social tem na segregação a sua dimensão espacial, a resistência tem a sua dimensão espacial nos resíduos: "No espaço também se localizam os resíduos capazes de apontar as virtualidades abertas pela prática espacial, que caminham em direção contrária, posto que as lutas que surgem da produção da consciência apontam as coações e as cisões criadas no processo como seu produto" (CARLOS, 2015, p. 50). A apropriação dos espaços, seja no plano individual, a casa, ou no plano coletivo são uma forma de resistência à expansão do mundo da mercadoria para todas as esferas da vida. As relações sociais, e sua concretização no espaço, acontecem nos planos individual (ato de habitar) e coletivo (realização da sociedade) (CARLOS, 2015), a luta pela moradia e pelos espaços públicos (como a praça) é uma resistência dos usos, da apropriação e da possibilidade de construir relações sociais distintas que não estejam completamente subordinadas ao mundo da mercadoria.

95 Les résistances et les insoumissions sont toujours mues par un souci de dignité. Elles naissent de l'indignation, toujours renaissante et toujours renouvelée, jamais lasse et jamais blasée, qui impose de "faire front aux affronts"; de l'indignation à laquelle se nourrissent les vertus rationnelles de fermeté, de confiance et de persévérance. De courage aussi. Le courage, rare et banal à la fois,d'aller contre; le courage qui fait se dresser ceux qui ont le sentiment d'avoir été offensés sur un point de dignité, d'avoir subi non seulement l'échec mais le mépris. (BENSAID, 2001, p. 40) 
Ao produzirmos coletivamente nossas cidades, produzimos coletivamente a nós mesmos. Projetos referentes ao que desejamos que sejam nossas cidades são em consequência projetos referentes a possibilidades humanas, a quem queremos ou, o que talvez seja mais pertinente, a quem não queremos vir a ser (HARVEY, 2000, p. 210).

Dessa forma, o projeto de construção de outra cidade é o projeto de construção de outra vida.

Reimaginar e reconstruir a cidade necessariamente passa por reacender o farol utópico. 


\section{Considerações Finais}

O deficit habitacional no Brasil é uma das expressões da grande desigualdade social e a alta concentração da propriedade fundiária é um componente central desta desigualdade. No meio rural e no urbano se organizam movimentos para lutar por uma distribuição mais justa da propriedade: as lutas pela reforma agrária e pela moradia. $\mathrm{Na}$ atualidade, a questão habitacional está longe de ser a falta de moradias, pois existe um grande estoque imobiliário ocioso - o problema é um sistema econômico em que é vantajoso manter a especulação imobiliária, com um grande estoque de terras urbanas inutilizado e sem cumprir sua função social.

A função social da propriedade foi estabelecida no ordenamento jurídico brasileiro pela Constituição Federal de 1988, e no entanto em poucos casos ela é acionada para democratizar o acesso à moradia. Até mesmo em casos em que os proprietários têm significativas dívidas com a municipalidade, pelo não pagamento de IPTU, a Justiça lhes dá ganho de causa em disputas. ${ }^{96}$ Demonstrando que, na prática, o direito à propriedade prevalece, ainda que não seja cumprida sua função social.

Em teoria, o direito a propriedade não é absoluto, a Constituição Federal e o Estatuto da Cidade estabelecem a função social da propriedade e o dever das municipalidades de legislar sobre esta e aplicar edificação ou parcelamento compulsórios, IPTU progressivo no tempo e desapropriação dos imóveis para garanti-la. No entanto, essas medidas raramente são aplicadas. Até mesmo com os imóveis públicos a função social da propriedade não era garantida; somente em 2007, após grande pressão popular, foi criada a lei que facilita a doação de imóveis da União abandonados ou subutilizados para habitação de interesse social. Na prática, o direito à propriedade prevalece ao direito à moradia, e são poucas as ações do poder público para garantir a função social da propriedade e facilitar o acesso dos nãoproprietários a moradias de melhor qualidade. Em períodos de crise econômica e aumento do desemprego, como vivemos atualmente, aumenta o número de famílias incapazes de pagar o aluguel, muitas delas ocupam prédios vazios ou constroem moradias irregulares nas periferias. Sem que exista uma política de controle dos preços dos aluguéis e a aplicação dos

96 Um caso que teve repercussão internacional, foi a reintegração de posse de um assentamento irregular conhecido como Pinheirinho, em São José dos Campos-SP. Mais de 6 mil pessoas foram expulsas mediante extrema força policial de um terreno que estava há oito anos desocupado e cujo proprietário tem dívidas milionárias com a Prefeitura. O caso foi denunciado na Organização dos Estados Americanos por ferir os direitos humanos. 
mecanismos que impedem que imóveis permaneçam por anos e até décadas ociosos, temos contraditoriamente um grande deficit habitacional e uma grande quantidade de unidades habitacionais vagas.

Os últimos programas de HIS tampouco tocam na questão da propriedade fundiária e da concentração de terras. Ao não definir áreas prioritárias nem formar um banco de terras em parceria com os municípios, deixam para a iniciativa privada decidir onde e quantas moradias serão construídas. O próprio programa MCMV provocou um aumento significativo nos preços das terras e, em consequência, elevou as despesas públicas com a aquisição de terras. O programa, com a ambiciosa meta inicial de construção de 1 milhão de moradias não planejou nenhum mecanismo para mitigar a especulação imobiliária que pressionou significativamente os preços de terras na última década. Além disso, falta fisscalização adequada das moradias construídas - e com grandes subsídios públicos - e sua qualidade é bastante questionável, pois muitos empreendimentos em poucos anos já apresentam problemas estruturais. ${ }^{97} \mathrm{O}$ MCMV foi desenhado sem a participação do Conselho das Cidades e, ainda que tenha sido importante para combater o deficit habitacional, não atingiu os locais mais críticos, pois justamente nas regiões metropolitanas o deficit é maior, mas também é mais alto o custo da terra e as empreiteiras preferem construir em cidades menos populosas, onde a lucratividade é maior. Dessa forma, um investimento significativo do governo federal foi deixado nas mãos das empresas para decidir onde iriam empregá-lo, ou seja, tornou-se uma privatização da política urbana. Daí surge o questionamento: o programa tinha como prioridade produzir habitação de qualidade para famílias de baixa renda ou impulsionar o setor da construção civil como estratégia contra a crise econômica?

Do outro lado temos um estoque imobiliário ocioso praticamente intocado pelos mecanismos legais destinados a garantir que cumpra sua função social. Parte desse estoque imobiliário é considerado patrimônio histórico e não se considera seu potencial habitacional. Há uma mentalidade elitista no Brasil, de que casas com valor arquitetônico reconhecido não podem ser moradia de trabalhadores pobres, há um ideal de que esses imóveis devem ser museus e centros culturais, ou abrigar comércio e serviços voltados para atividades turísticas. Ainda que, durante décadas, tenham sido utilizados como moradia precária por trabalhadores que não tinham condições financeiras de manter suas fachadas preservadas.

97 Auditoria de 2017 da Controladoria-Geral da União concluiu que mais da metade dos conjuntos do MCMV analisados tinham algum tipo de problema, sendo que alguns casos eram bastante graves, como o de um conjunto na periferia de Manaus em que, segundo os bombeiros, vários apartamentos tinham rachaduras e infiltrações, oferecendo risco crítico aos moradores. 
Os poucos projetos no Brasil que utilizam o patrimônio histórico com fins de habitação social não passam de projetos-piloto. O caso de Olinda foi a implantação bem-sucedida de uma política de preservação e melhoria de habitações, com um orçamento muito inferior ao que seria gasto na construção de novas moradias. No entanto, com o fim do BNH, o programa ficou restrito àquele município e não teve uma ampliação de escala. Já no caso de Salvador, as poucas famílias que permaneceram no centro histórico lutaram muito para isso. Tiveram que resistir a uma política que dizia claramente que o Pelourinho não era lugar para pobre morar. Infelizmente, muitas habitações populares quando tem seu valor arquitetônico ou histórico reconhecido, passam a ter políticas públicas contrárias a função como moradia. Com o reconhecimento do valor arquitetônico os proprietários veem uma oportunidade para aumentar os seus rendimentos mudando a função dos imóveis, vários interesses tentam transformar o local em um ponto turístico, incentivar atividades de lazer e o resultado é a expulsão de muitas famílias, e o patrimônio é usado para justificar essa expulsão.

O Alegra Centro Habitação foi um projeto que tentou pressionar os proprietários para adequarem os cortiços a parâmetros de habitabilidade sem grandes inversões do município. No entanto, o projeto fracassou pelo desinteresse dos proprietários em investir e famílias foram despejadas. Não foram pensados mecanismos para evitar a expulsão das famílias ou o aumento do preço do aluguel após as reformas. Não foi realizado um levantamento pela Prefeitura sobre quais imóveis tinham IPTU em atraso, e, com isso, talvez utilizar as dívidas para negociar as reformas com os proprietários, ou até mesmo desapropriar as casas. O art. 24 da Lei 8.245/1991, que preve o pagamento dos aluguéis em juízo quando a habitação não têm os parâmetros mínimos de habitabilidade ou oferece risco aos moradores, para que sejam feitas as reformas necessárias, também não foi considerado uma opção para pressionar os proprietários a manter condições mínimas das moradias.

Se cada casarão pudesse ser reformado e transformado em quatro ou cinco apartamentos com quarto, sala, cozinha e banheiro, os custos seriam mais baixos do que os R $\$ 30$ mil por apartamento do Programa Crédito Solidário (ou os dos imóveis do MCMV, que têm valores previstos a partir de $\mathrm{R} \$ 80 \mathrm{mil}$ ), especialmente se os imóveis tivessem dívidas com a Prefeitura e se pudesse reduzir o valor a ser pago como indenização pela desapropriação. Poderia ser criado um programa similar ao projeto-piloto realizado em Olinda, em que foram desenhadas linhas de crédito específicas para a reforma do casario colonial. Claro que um projeto deste tipo reduziria a densidade habitacional de cada imóvel e seriam necessários 
outros projetos para absorver a população restante, como o PAC da CDHU.

Uma possibilidade, para que esses apartamentos não fossem vendidos pelas famílias como frequentemente acontece com imóveis da CDHU ou das Cohabs, seria o direcionamento destes para locação social, em que cada família pagaria um valor proporcional à sua renda, de maneira similar ao programa de aluguel social República de Idosos. Com isso, a Prefeitura seria responsável pelas condições dos apartamentos e as famílias não teriam gastos muito altos com aluguel ou financiamento.

Existem várias possibilidades e modelos que podem ser inspiradores, tanto no exterior como no Brasil, mas não se pode olhar o potencial habitacional do casario histórico da mesma forma como se planeja a construção de novos empreendimentos. Linhas distintas de crédito tem que ser oferecidas aos proprietários que queiram investir, adequadas para as reformas necessárias e para o perfil das famílias que lá vivem.

Apesar das críticas que foram feitas neste trabalho em relação ao Alegra Centro, sua ideia inicial, na Área de Proteção Cultural 1, é interessante. Ao proteger edificações históricas do entorno de bens tombados, o enfoque da preservação é o conjunto arquitetônico e não construções isoladas. Ainda que não esteja explicitado no programa, se aproxima da ideia do patrimônio como documento e possibilita leituras da cidade através do tempo, porque o centro reúne construções de diversas épocas, sejam estas de grande destaque, como a Casa da Frontaria Azulejada e a Bolsa do Café, ou construções vernaculares, mas importantes no conjunto paisagístico.

As isenções fiscais concedidas aos proprietários que recuperem as fachadas são uma forma interessante de combinar investimentos públicos e privados para a preservação, e ainda foram responsáveis pela abertura de um número significativo de empresas no centro, aumentando a dinâmica do bairro e o público que o frequenta. Sem dúvida essas novas empresas e, consequentemente, os novos empregos gerados são positivos, mas o poder público nunca teve a preocupação de incluir a população dos bairros centrais nesses programas. Não foram adotados programas de formação para trabalhadores ou ações que estimulassem os empresários a contratar os moradores desses bairros. A maioria das empresas que foram abertas é de comércio e serviços, áreas que não exigem mão de obra altamente qualificada, e poderia ter um impacto muito positivo para os moradores do Paquetá, por exemplo, conseguir um emprego estável e sair da informalidade.

No entanto, a Prefeitura construiu o programa sem um diálogo com os moradores, o que é 
ainda pior no caso da APC 2, que abarca as suas casas e determina a proteção das suas fachadas sem pontuar a precariedade dos interiores. A delimitação dessa área tem outras incongruências: existem somente dois bens tombados, o Mercado Público (tombado mais pela sua função do que por seu valor arquitetônico) e o Cemitério do Paquetá, pois não existem na área edifícios de excepcional valor arquitetônico; o próprio conjunto arquitetônico é pouco uniforme, existem casarões construídos entre 1890 e 1930 intercalados com grandes armazéns e áreas de depósito de contêineres. Talvez no intuito de preservar os casarões existentes, a Prefeitura tenha pensado no perímetro de proteção, mas ignorou até mesmo a Zeis 3 sobreposta à área. Se a prioridade, segundo a legislação, dessa zona é a habitação social e a construção de equipamentos públicos voltados para a população moradora (como de fato existem: creche, posto de saúde, restaurante bom prato, lavanderia comunitária), como desenhar um programa de proteção do patrimônio sem levar em consideração os cortiços?

A questão da gentrificação do centro de Santos divide opiniões: embora o programa Alegra Centro tenha um caráter elitista e voltado para aumentar atividades turísticas e de lazer, ele é um programa que fomenta a gentrificação? É importante lembrar que, diferentemente de outros projetos claramente gentrificadores, o Alegra Centro não pautava a questão habitacional até 2008, quando o Alegra Centro Habitação foi criado, e este previa a manutenção dos moradores nos locais, não a vinda de novos moradores. Como já foi apresentado, mais recentemente a Prefeitura passou a mostrar interesse em atrair habitações de mercado popular para os bairros centrais, mas ainda não foram desenvolvidas políticas públicas que estimulem diretamente essas construções. A mudança de pessoas de classes de rendimentos mais elevados para o centro parece pouco provável, pois é um público que tradicionalmente prefere viver próximo à orla marítima. $\mathrm{O}$ centro talvez possa atrair famílias jovens, que prefiram poder ir a pé para o trabalho e ter bastante comércio perto de suas moradias. Por outro lado, o Paquetá ainda é alvo de bastante receio por parte da população santista, é visto como um bairro perigoso, sujo. Segundo relatos de uma dona de banca de frutas do Mercado Municipal, nas últimas duas décadas muitos clientes deixaram de frequentar o mercado porque se sentem inseguros e porque consideram o bairro desagradável. Hoje é mais provável que moradores de cortiços sejam expulsos de suas casas para que estas sejam transformadas em armazéns do que em casas de elite. No entanto, em alguns anos ou décadas o impacto do restauro dos casarões e a possível construção de moradias de mercado popular nos bairros centrais, associados às torres de escritórios já existentes nos entornos das 
APCs, podem pressionar os preços dos aluguéis dos cortiços. Talvez alguns proprietários tomem a iniciativa de investir em seus imóveis, transformá-los em pequenos apartamentos voltados para casais jovens sem filhos e aumentar significativamente os aluguéis. Com a atual crise econômica e um mercado imobiliário pouco dinâmico é difícil tecer prognósticos das mudanças nos bairros centrais, mas o interesse da municipalidade em aumentar o uso habitacional dos bairros centrais, a relativa falta de novos espaços a serem construídos (Santos é uma das cidades mais verticalizadas do país e sua porção continental é em grande parte área de proteção ambiental) e, paralelamente, a mudança de paisagem do centro (APC 1), com novos comércios, serviços, bares e restaurantes, têm potencial para desencadear um processo de gentrificação.

Há também a questão de como os moradores dos bairros centrais vão reagir no caso de se estruturarem políticas públicas para atrair classes de rendimentos médios para o centro. Qual seria o desfecho dessas disputas? A Prefeitura faria concessões e construiria em conjunto um projeto habitacional para os moradores de cortiços? Ou o processo de expulsão transformaria os bairros centrais e reforçaria os processos de segregação socioespacial? Não cabe fazer previsões, mas pensar em estratégias para combater a valorização imobiliária e a expulsão dos moradores e lutar pela adoção de processos mais participativos nas políticas de habitação, com uma aproximação entre o poder público municipal e a população.

As relações entre a ACC e a Prefeitura são bastante conflituosas. Além das críticas ao Alegra Centro por disponibilizar recursos para o restauro das fachadas sem oferecer uma alternativa habitacional aos moradores de cortiços, a associação fez inúmeras reivindicações para que a questão da moradia fosse pauta de programas municipais e a comunidade fosse chamada para discutir soluções. Outros conflitos com o poder público municipal se relacionavam ao condomínio Vanguarda: primeiro a Prefeitura dificultou muito a expedição da certidão negativa do terreno, porque não queria isentar a ACC da dívida de taxa de lixo do imóvel quando este ainda pertencia à União; depois, com o projeto já aprovado pela Caixa, a Prefeitura não quis aportar recursos ao empreendimento (o que poderia melhorar o padrão de acabamento dos apartamentos, por exemplo, que é bem simples no PCS) porque não queria criar o precedente de HIS com três dormitórios, para evitar que no futuro movimentos de moradia reivindicassem apartamentos desta tipologia.

Essa tipologia, aliás, foi um importante avanço, possibilitado pela intensa participação dos membros da associação no desenvolvimento do projeto. Ao contrário de projetos que são 
elaborados por técnicos, sem contato com os futuros moradores, como acontece na CDHU e nas Cohabs, em que certas preferências e necessidades dos moradores não são levadas em consideração. Existem famílias com configurações muito diversas nos cortiços, por isso é importante a variedade de tipologias, apartamentos de um, dois e três quartos, para atender das menos às mais numerosas famílias. Atendendo à demanda dos associados, os apartamentos do térreo são mais elevados, de maneira a garantir sua privacidade; os banheiros têm a pia do lado de fora; a cozinha de alguns apartamentos é do tipo americana; existe espaço no prédio para a separação do lixo reciclável. Todos esses elementos só foram possíveis com a participação dos membros da ACC na elaboração do projeto, uma grande vantagem da autogestão.

A autogestão propicia também uma maior integração entre as famílias que morarão no condomínio, pela convivência nas assembleias, no mutirão - ainda que seja um processo bastante cansativo para as pessoas que já trabalham durante a semana trabalhar também nos fins de semana para diminuir o custo da habitação. No caso da ACC, muitas das famílias já se conheciam, porque viviam há muitos anos no mesmo bairro. Essa participação, tanto no projeto quanto na obra em si, reduz as chances de os moradores venderem seus apartamentos em um futuro próximo, como frequentemente acontece em conjuntos das Cohabs ou da CDHU, e normalmente a preços bem abaixo do mercado.

No entanto, a produção habitacional realizada através de autogestão tem vários desafios: 1) o próprio desenho do programa MCMV, por exemplo, acarreta um forte aquecimento do mercado imobiliário e as entidades têm dificuldades em encontrar terrenos a um preço acessível, o que as obriga a adquirir terrenos nas franjas urbanas para poder viabilizar seus empreendimentos; 2) a etapa de aprovação do projeto, de conseguir as licenças e documentações exigidas pelas Prefeituras e pela Caixa, é bastante difícil, e as lideranças das entidades têm que aprender a realizar todas essas burocracias - quando contam com uma boa assessoria técnica e fazem parte de movimentos nacionais de luta por moradia, o processo é um pouco facilitado, mas, ainda assim, esses trâmites podem levar alguns anos; 3) o processo de acompanhamento da obra também é bastante difícil, envolvendo verificar o trabalho realizado pela empreiteira e o trabalho de apoio dos mutirantes, manter a contabilidade e conseguir comprar materiais com um orçamento que se desatualiza ao longo da obra; 4) é preciso, ainda, conciliar os interesses dos futuros moradores com as possibilidades do orçamento, assim como cultivar boas relações com a assessoria técnica e o poder público. 
Os mais de 80 empreendimentos do PCS que estão paralisados em todo país e o fato de o MCMV-E ter uma taxa bem menor de entrega do que os empreendimentos das empreiteiras são indicativos, de um lado, das dificuldades das entidades em finalizar as construções e, de outro, das deficiências da Caixa e das Prefeituras em apoiarem as entidades. Fornecer cursos para as lideranças e ter um atendimento mais acessível são medidas que a Caixa poderia tomar para aumentar a chance de ter empreendimentos concluídos e uma melhor gestão dos recursos neles investidos.

O projeto de HIS melhor sucedido dentre os analisados neste trabalho é sem dúvida dos IAPs. Os imóveis construídos não tinham uma homogeneidade arquitetônica, eram pensados de acordo com as características da cidade, do público-alvo e do terreno. E com um padrão de qualidade tão alto que até hoje, passados mais de 60 ou 70 anos de suas construções, são bons imóveis. Uma das razões para a qualidade dos edifícios é que parte desses pertenciam aos institutos e eram alugados aos seus associados, o instituto não queria, portanto, ter grandes despesas com manutenção desses imóveis. Além disso, os projetos e acompanhamento da obra eram realizados pela equipe técnica própria de cada instituto. Práticas opostas ao Minha Casa Minha Vida que deixa às construtoras a decisão de onde, quanto e como construir. Ainda que o contexto histórico dos dois programas seja bastante distinto, e que os IAPs tenham sido restritos a determinadas categorias de trabalhadores e o MCMV tenha a vantagem de ampliar o público-alvo, algumas lições poderiam ser consideradas.

No caso dos programas produção imobiliária autogestionária como o PCS e o MCMV-E, um dos grandes entraves é a falta de conhecimento técnico das associações e movimentos e as dificuldades no pagamento das assessorias técnicas (que muitas vezes recebem pelo projeto anos após ele ser realizado). Uma possibilidade que teria facilitado a melhor qualidade dos projetos e sem dúvida teria diminuído o número de obras paradas, seria a formação de equipes técnicas nas Gidur da Caixa Econômica Federal. Sem dúvida existem assessorias técnicas muito competentes e comprometidas com as questões sociais, como a Peabiru entrevistada na elaboração dessa pesquisa, no entanto, haveriam vantagens da Caixa formar sua própria equipe de técnicos: maior facilidade na aprovação dos projetos, maior facilidade no diálogo entre as diversas esferas do poder público, maior capacidade de acompanhar a obra e o seu orçamento. Em nenhuma maneira isso impediria um acompanhamento e participação dos movimentos na elaboração do projeto, no acompanhamento da obra e na realização de mutirão (caso optassem por essa modalidade). 
$\mathrm{Na}$ trajetória de luta da ACC para permanecer no centro de Santos foram essenciais a conquista do terreno, a orientação de movimentos nacionais de luta por moradia e o suporte de assessorias técnicas comprometidas não somente com o projeto arquitetônico, mas também em dar ferramentas para a associação conquistar autonomia em suas diversas ações. As ações da ACC se desenvolvem de forma distinta de outros movimentos, porque, apesar de a questão central ser a moradia, seus integrantes também se mobilizam por outras demandas: se envolvem em reivindicações por creches e postos de saúde, participam em manifestações sobre a questão da água, se organizam em projetos de economia solidária para tentar melhorar a condição financeira dos participantes, dão apoio a movimentos locais de cultura, como o hip-hop, se esforçam para atrair projetos culturais, especialmente para as crianças, organizam ações do Dia da Consciência Negra, e apoiam e trocam experiências com outros movimentos de moradia da cidade. A amplitude de suas ações vai em direção ao sonho de uma vida melhor em uma cidade melhor. A ACC tem uma pauta ampla de reivindicações e mobilizações por direitos, que em sua totalidade conformam uma luta por justiça social e pelo direito à cidade. 


\section{Referências Bibliográficas}

ALMANAQUE DE SANTOS: Revista do Instituto Histórico e Geográfico de Santos. Ano 1. n. 1, Santos: IHGS, 2011.

ALVAREZ, I. P. A produção e reprodução da cidade como negócio e segregação. In: CARlos, A. F. A.; VOlOCHKO, D.; AlVAREZ, I. P. (Org.) A Cidade como Negócio. São Paulo: Contexto, 2015. p. 65-79.

ARANTES, O. Uma estratégia fatal: a cultura nas novas gestões urbanas. In: ARANTES, O.; VAINER, C.; MARICATO, E. A cidade do pensamento único: desmanchando consensos. Petrópolis: Vozes, 2000. p. 11-74.

ARANTES, A. A. (org.) Produzindo o passado: estratégias de construção do patrimônio cultural. São Paulo: Braziliense, 1984.

ARAÚJO, D. P. A preservação de bens arquitetônicos em Santos: 1974-1989. 2008, 221 p. Dissertação (Mestrado em Arquitetura) - Faculdade de Arquitetura e Urbanismo, Universidade de São Paulo, São Paulo, 2008.

ARAÚJO FILHO, J. R. A expansão urbana de Santos. São Paulo: Edusp, 1965.

ARAÚJO FILHO, J. R. Santos, o porto do café. Rio de Janeiro: Biblioteca Geográfica Brasileira, 1969.

ASSOCIAÇÃO COMUNIDADE DE MÃOS DADAS. Imóvel foi entregue à Associação dos Cortiços do Centro. 27 jul. 2007. Disponível em: <http://www.acmd.org.br/imovel-foientregue-a-associacao-dos-corticos-do-centro/>. Acesso em: 31 out. 2017.

ASSOCIAÇÃO COMUNIDADE DE MÃOS DADAS. Inauguração de padaria comunitária marca utilização de imóvel pela ACC. 15 jan. 2010. Disponível em:

$<$ http://www.acmd.org.br/inauguracao-de-padaria-comunitaria-marca-utilizacao-de-imovelpela-acc/>. Acesso em: 31 out. 2017.

AZEVEDO, P. O. A recuperação do patrimônio habitacional. Revista de Urbanismo e Arquitetura, Salvador, v. 1, n. 2, 1988. p. 35-51.

AZEVEDO, S.; ANDRADE, L. A. G. Habitação e Poder: da Fundação Casa Popular ao Banco Nacional de Habitação. Rio de Janeiro: Centro Edelstein de Pesquisas Sociais, 2011.

BANCO CENTRAL DO BRASIL. Disponível em: <http://www.bcb.gov.br/pt-br\#!/home> . Acesso em: 02 mar. De 2018.

BARBOSA, A. Despejo na Favela. In: ADONIRAN BARBOSA. Coletânea MPB compositores, v. 7. 1997. 1 CD. Faixa 4, 2:44 min.

BARBOSA, M. V.; DIAS, N. S.; CERQUEIRA, R. M. M. Santos na formação do Brasil: 
500 anos de história. Santos: Prefeitura Municipal de Santos/Fundação Arquivo e Memória de Santos, 2000.

BENJAMIN, W. Obras escolhidas. Magia e técnica, arte e política: ensaios sobre literatura e história da cultura. São Paulo: Brasiliense, 1996, v. 1.

BERNARDINI, S. P. Os planos da cidade: As políticas de intervenção urbana em Santos. De Estevan Fuertes a Saturnino de Brito (1892-1910). São Carlos: RiMa, 2006.

BENSAID, D. Résistances: Essai de taupologie générale. Paris: Fayard, 2001.

BIDOU-ZACHARIASEN, C. (coord.) De volta à cidade: Dos processos de gentrificação às políticas de "revitalização" dos centros urbanos. São Paulo: Annablume, 2006.

BLANC, A.; BOSCO, J. O Mestre-Sala dos Mares. Intérprete: Elis Regina. In: ELIS REGINA. Elis. [S.I.]: CBD-Phonogram/Philips. Remasterizado em digital. 1993. 1 CD. Faixa 5 .

BOLLE, W. Cultura, patrimônio e preservação: Texto I. In: ARANTES, A. A. (org.) Produzindo o passado: estratégias de construção do patrimônio cultural. São Paulo: Braziliense, 1984.

BONDUKI, N. G. Origens da habitação social no Brasil. Análise Social, Revista do Instituto de Ciências Sociais da Universidade de Lisboa, Lisboa, v. XXIX, n. 127, p. 711732, 1994. Disponível em: <http://analisesocial.ics.ul.pt/?page_id=14>. Acesso em: 15 abr. 2016.

BONDUKI, N. G. Os pioneiros da habitação social: Cem anos de política pública no Brasil. São Paulo: Editora Unesp; Edições Sesc, 2012, v. 1.

BONDUKI, N. G.; KOURY, A. P. Os pioneiros da habitação social: Inventário da produção pública no Brasil entre 1930 e 1964. São Paulo: Editora Unesp; Edições Sesc, 2012, v. 2. BOSI, E. Memória e sociedade: lembranças de velhos. São Paulo: T. A. Queiroz, 1979.

BOSI, E. Memória e sociedade: lembranças de velhos. São Paulo: T. A. Queiroz, 1979.

BRAGA, R. A. M. A política municipal de habitação na cidade de Santos na década de 1990. 2004. 181 p. Dissertação (Mestrado em Engenharia Urbana) - Centro de Ciências Exatas e de Tecnologia, Universidade Federal de São Carlos, São Carlos, 2004.

BRASIL. Constituição da República Federativa do Brasil de 1988. Brasília, 05 out. de 1988. BRASIL. Lei no 8.245 de 18 de outubro de 1991. Dispõe sobre as locações dos imóveis urbanos e os procedimentos a elas pertinentes. Diário Oficial da União, Brasília, 21 out. de 1991.

BRASIL. Lei 10.257 de 10 de julho de 2001. Regulamenta os arts. 182 e 183 da Constituição Federal, estabelece diretrizes gerais da política urbana e dá outras providências. Diário Oficial da União, Brasília, 11 jul. de 2001. 
BRASIL. Lei ${ }^{\circ} 11.481$ de 31 de maio de 2007. Dá nova redação a dispositivos das Leis $n^{0}$ 9.636, de 15 de maio de 1998, 8.666, de 21 de junho de 1993, 11.124, de 16 de junho de 2005, 10.406, de 10 de janeiro de 2002 - Código Civil, 9.514, de 20 de novembro de 1997, e 6.015, de 31 de dezembro de 1973, e dos Decretos-Leis $n^{\circ} 9.760$, de 5 de setembro de 1946, 271, de 28 de fevereiro de 1967, 1.876, de 15 de julho de 1981, e 2.398, de 21 de dezembro de 1987; prevê medidas voltadas à regularização fundiária de interesse social em imóveis da União. Diário Oficial da União, Brasília, 31 mai. 2007.

CADEIA Velha de Santos volta a ser Oficina Cultural Pagu. Portal do Governo. São Paulo, 28 jul. 2016. Disponível em: <http://www.oficinasculturais.org.br/noticias/ver.php?id=545>. Acesso em: 13 set. 2017.

CAIXA ECONÔMICA FEDERAL. Minha Casa Minha Vida. Disponível em: $<$ http://www.caixa.gov.br/voce/habitacao/minha-casa-minha-vida/Paginas/default.aspx $>$. Acesso em: 02 mar. de 2018.

CAIXA ECONÔMICA FEDERAL. Programa Crédito Solidário. Disponível em: $<$ http://www.caixa.gov.br/voce/habitacao/habitacao-popular/credito-solidariofds/Paginas/default.aspx>. Acesso em: 02 mar. de 2018.

CAMILO, D. Teatros de Santos não tem vistoria do corpo de bombeiros. Diário do Litoral, Santos, 12 mar. 2013. Disponível em: <http://www.diariodolitoral.com.br/cotidiano/teatrosde-santos-nao-tem-vistoria-do-corpo-de-bombeiros/7277/>. Acesso em: 22 mar. 2017.

CANCLINI, N. G. O patrimônio cultural e a construção imaginária do nacional. Revista do Patrimônio Histórico e Artístico Nacional, Brasília, n. 23, p. 95-115, 1994.

CARLOS, A. F. A. "Novas" contradições do espaço. In: O espaço no fim do século: a nova raridade. São Paulo: Editora Contexto, 1999, p. 62-74.

CARLOS, A. F. A. Condição Espacial. São Paulo: Contexto, 2011.

CARVALHO, M. C. Falta de política arrasa patrimônio histórico. Folha de S. Paulo, São Paulo, 3 out. 1994. Ilustrada, p. 5. Disponível em: <https://acervo.folha.com.br/leitor.do? numero $=12565 \&$ anchor $=4857985$ \&origem $=$ busca\& $\& d=616$ b0feaaabad $3 \mathrm{bbc} 2 \mathrm{db} 5707 \mathrm{~b} 7806 \mathrm{de}$ 0>. Acesso em: 7 out. 2017.

CHAUÍ, M. Os trabalhos da memória [Apresentação]. In: BOSI, E. Memória e sociedade: lembranças de velhos. São Paulo: T. A. Queiroz, 1979, p. XVII-XXXIV.

CIFELLI, G. O papel da redução da narrativa no processo de valorização cultural e promoção turística do patrimônio de Ouro Preto (MG) e Salvador (BA). Boletim Campineiro de Geografia, Campinas, v. 6, n. 2, 2016.

CIFUENTES, C. La planificación de las áreas patrimoniales de Quito. Centro-h, Organización Latinoamericana y del Caribe de Centros Históricos, Quito, n. 1, p. 101-114, ago. 2008. Disponível em: $<$ http://www.redalyc.org/articulo.oa?id=115112534009>. Acesso em: 15 jan. 2018. 
CONDEPHAAT. Busca de Bens Tombados. Disponível em: $<$ http://condephaat.sp.gov.br/bens-protegidos-online/>. Acesso em 29 mar. 2016.

CONDEPHAAT. Vila Economizadora. Disponível em: $<$ http://condephaat.sp.gov.br/benstombados/vila-economizadora/>. Acesso em 30 jan. 2018.

CONTROLADORIA GERAL DA UNIÃO. Minha Casa Minha Vida: 56,4\% dos imóveis avaliados apresentam defeitos na construção. 16 ago. de 2017. Disponível em: $<$ http://www.cgu.gov.br/noticias/2017/08/minha-casa-minha-vida-56-4-dos-imoveisavaliados-apresentam-defeitos-na-construcao>. Acesso em: 05 mai. 2018.

COSTA, F. C. Nota sobre o combate a imóveis vazios no centro de São Paulo: constatações, possibilidades e utopias da reforma urbana. In: ENANPUR - Encontro Nacional da Associação Nacional de Pós-Graduação e Pesquisa em Planejamento Urbano e Regional, XVII, 2017, São Paulo. Anais... Disponível em: <http://anpur.org.br/xviienanpur/principal/? page_id=1360>. Acesso em: 7 jun. 2017.

COUTINHO, C. N. Gramsci: um estudo sobre seu pensamento político. Rio de Janeiro: Civilização Brasileira, 1999.

DAMIANI, A. L. A cidade (des)ordenada: concepção e cotidiano do conjunto habitacional Itaquera I. 1993. 358 p. Tese (Doutorado em Geografia Humana) - Faculdade de Filosofia, Letras e Ciências Humanas, Universidade de São Paulo, São Paulo, 1993.

EM SANTOS, idosos aliviam solidão e mantêm vida ativa em repúblicas. TV Tribuna/G1, Santos, 7 nov. 2012. Disponível em: $<$ http://g1.globo.com/sp/santosregiao/noticia/2012/11/em-santos-idosos-aliviam-solidao-e-mantem-vida-ativa-emrepublicas.html>. Acesso em: 15 set. 2017.

ENGELS, F. A situação da classe trabalhadora na Inglaterra. São Paulo: Boitempo, 2008.

FIPEZAP. Disponível em: <http://fipezap.zapimoveis.com.br/>. Acesso em: 20 nov. 2017.

FÓRUM da Cidadania. Associação Comunidade de Mãos Dadas. Santos, 18 jul. 2003. Disponível em: <http://www.acmd.org.br/forum-da-cidadania/>. Acesso em: 30 out. 2017.

FREHSE, F. Potencialidades do método regressivo-progressivo: pensar a cidade, pensar a história. Tempo Social, Revista de Sociologia da USP, São Paulo, v. 13, n. 2, p. 169-184, nov. 2001.

FREIRE, P. Denúncia, anúncio, profecia, utopia e sonho. In: BRASIL; SENADO FEDERAL. O livro da profecia: o Brasil no terceiro milênio. Brasília: Coleção Senado, 1997.

FUNDAÇÃO ARQUIVO E MEMÓRIA DE SANTOS. Disponível em: $<$ http://www.fundasantos.org.br/>. Acesso em 13 jul. 2017.

FUNDAÇÃO JOÃO PINHEIRO. Deficit habitacional no Brasil 2013-2014. Belo Horizonte: Fundação João Pinheiro, 2016. Disponível em: 
$<$ http://www.fjp.mg.gov.br/index.php/docman/cei/informativos-cei-eventuais/634-deficithabitacional-06-09-2016/file>. Acesso em: 25 ago. 2017.

FUNDAÇÃO SISTEMA ESTADUAL DE ANÁLISE DE DADOS (SEADE). Disponível em: $<$ http://www.seade.gov.br/>. Acesso em: 23 nov. 2017.

GOHN, M. da G. A força da periferia: a luta das mulheres por creches em São Paulo. Petrópolis: Vozes, 1985.

GOHN, M. da G. Teoria dos movimentos sociais: paradigmas clássicos e contemporâneos. São Paulo: Edições Loyola, 2007.

GONZAGUINHA. E Vamos à Luta. Intérprete: Gonzaguinha. In: GONZAGUINHA. De volta ao começo. EMI. 1980. Long play. Faixa 5.

GUSMÃO, F. M. B. Empoderamento e preservação do patrimônio cultural: o caso do programa de recuperação e revitalização de núcleos históricos projeto-piloto Olinda/PE, 19811989. 2011. 172 f. Dissertação (Mestrado em Gestão Pública) - Centro de Ciências Aplicadas, Universidade Federal de Pernambuco, Recife, 2011.

HARVEY, D. A produção capitalista do espaço. São Paulo, Annablume, 2005.

HARVEY, D. Espaços de Esperança. São Paulo: Edições Loyola, 2000.

HARVEY, D. Cidades rebeldes: do direito à cidade à revolução urbana. São Paulo: Martins Fontes, 2014.

HIERNAUX-NICOLAS, D. A reapropriação de bairros da Cidade do México pelas classes médias: em direção a uma gentrificação? In: BIDOU-ZACHARIASEN, C. (coord.) De volta à cidade: Dos processos de gentrificação às políticas de "revitalização" dos centros urbanos. São Paulo: Annablume, 2006, p. 229-264.

HOBSBAWM, E.; RANGER, T. (Org). A invenção das tradições. São Paulo: Paz e Terra, 1997.

INSTITUTO BRASILEIRO DE GEOGRAFIA E ESTATÍSTICA. Censo demográfico 2010: Aglomerados subnormais - primeiros resultados. Rio de Janeiro: IBGE, 2011.

INSTITUTO ELOS. Disponível em: <http://institutoelos.org/>. Acesso em: 02 mar. De 2018.

INSTITUTO PÓLIS. Litoral sustentável: desenvolvimento com inclusão social - resumo executivo de Santos. Base de dados até dez. 2012. Instituto de Estudos, Formação e Assessoria em Políticas Sociais, São Paulo. Disponível em: $<$ http://litoralsustentavel.org.br/resumos-executivos/resumo-executivo-de-santos/ $>$. Acesso em: 20 out. 2016.

JESUS, M. C. Quarto de Despejo: diário de uma favelada. São Paulo: Ática, 1995.

KAPRON, S. Economia popular solidária: política pública para o desenvolvimento. In: 
PINTAUDI, S. M. (org.) Economia solidária: um setor em desenvolvimento. São Paulo: Prefeitura de Rio Claro, 2002. p. 47-57.

KOHARA, L. T. Relação entre as condições de moradia e o desempenho escolar: estudo com crianças residentes em cortiços. 2009. 297 p. Tese (Doutorado em Arquitetura e Urbanismo) - Faculdade de Arquitetura e Urbanismo da Universidade de São Paulo, São Paulo, 2009.

LAGO, L. C. O associativismo produtivo na periferia urbana: novos conflitos em pauta. In: (Org.) Autogestão habitacional no Brasil: utopias e contradições. Rio de Janeiro:

Letra Capital - Observatório das Metrópoles, 2012.

LANNA, A. L. D. Uma cidade na transição: Santos 1870/1913. 1995. 224 p. Tese

(Doutorado em História Social) - Faculdade de Filosofia, Letras e Ciências Humanas, Universidade de São Paulo, São Paulo, 1995.

LEFEBVRE, H. Le droit à la ville. Paris: Éditions Anthropos, 1968.

LEFEBVRE, H. Du rural à l'urbain. Paris: Anthropos, 1970.

LIMA, R. Serra inaugura posto do Poupatempo em São Paulo. O Estado de S. Paulo, São Paulo, 9 out. 2008. Disponível em: <http://sao-paulo.estadao.com.br/noticias/geral,serrainaugura-posto-do-poupatempo-em-santos,256935>. Acesso em: 22 mar. 2017.

LIMA, R. Casa do Trem Bélico, em Santos, vai integrar projeto turístico. O Estado de S.

Paulo, Santos, 1 out. 2009. Disponível em: <http://www.estadao.com.br/noticias/geral,casado-trem-belico-em-santos-vai-integrar-projeto-turistico,443802>. Acesso em: 22 mar. 2017.

LOPES, B. Porto de Santos e a febre amarela. 1975. 181 p. Dissertação (Mestrado em História) - Faculdade de Filosofia, Letras e Ciências Humanas, Universidade de São Paulo, São Paulo, 1975.

MALAVSKI, P. D. O processo de revalorização do centro histórico de Santos (SP): As contradições do programa Alegra Centro. In: Encontro de Geógrafos da América Latina, XII, 2009, Montevidéu. São Paulo: Revista Paisagens, n. 9, p. 60-64, ago. 2010. Disponível em: $<$ https://www.revistas.usp.br/revistapaisagens/issue/viewFile/9779/pdf_6\#page $=61>$. Acesso em: 5 abr. 2015.

MARTINEZ, R. Prefeitura irá reformular o Alegra Centro neste ano. Diário do Litoral, Santos, 9 jan. 2017a. Disponível em: <http://www.diariodolitoral.com.br/cotidiano/prefeituraira-reformular-alegra-centro-neste-ano/94139/>. Acesso em: 15 out. 2017.

MARTINEZ, R. Laje cai e atinge trabalhador no centro histórico de Santos. Diário do Litoral, Santos, 6 mar. 2017b. Disponível em:

$<\mathrm{http}$ ://www.diariodolitoral.com.br/santos/laje-de-imovel-cai-e-deixa-um-ferido-acidenteocorreu-no-centro-de/96382/>. Acesso em: 6 fev. 2018.

MARTINS, J. S. Os camponeses e a política no Brasil: As lutas sociais no campo e seu 
processo político. Petrópolis: Editora Vozes, 1981.

MELÉ, P. (Re)investir nos espaços centrais das cidades mexicanas. In: BIDOU-

ZACHARIASEN, C. (coord.) De volta à cidade: Dos processos de gentrificação às políticas de "revitalização" dos centros urbanos. São Paulo: Annablume, 2006, p. 197-227.

MENDES, G.; HERSMDORF, M.; OLIVEIRA, N. Condomínios, repúblicas e vilas diversificam moradia para idosos. O Estado de São Paulo, São Paulo, s/d. Disponível em: $<$ http://infograficos.estadao.com.br/focas/planeje-sua-vida/condominios-republicas-e-vilasdiversificam-moradia-para-idosos $>$. Acesso em: 15 set. 2017.

MENESES, U. T. B. Benedito Calixto como documento: sugestões para uma releitura histórica. In: PINACOTECA DO ESTADO. Benedito Calixto: Memória Paulista. São Paulo: Projeto, 1990.

MINEIRO, E.; RODRIGUES, E. Do crédito solidário ao MCMV Entidades: uma história em construção. In: LAGO, L. C. (Org.) Autogestão habitacional no Brasil: utopias e contradições. Rio de Janeiro: Letra Capital - Observatório das Metrópoles, 2012.

MORAES, A. C. R. Contribuições para a gestão da zona costeira do Brasil: Elementos para uma geografia do litoral brasileiro. São Paulo: Edusp/Hucitec, 1999.

MOREIRA, F. A. O lugar da autogestão no governo Lula. 2009. 195 p. Dissertação (Mestrado em Arquitetura) - Faculdade de Arquitetura e Urbanismo, Universidade de São Paulo, São Paulo, 2009.

MOTTA, L. A apropriação do patrimônio urbano: do estético-estilístico nacional ao consumo visual global. In: ARANTES, A. A. O Espaço da Diferença. Campinas: Papirus, 2000.

MÜLLER, M. Parte da fachada de duas casas cai e destrói carro em Santos. A Tribuna, Santos, 23 dez. 2016. Disponível em: <http://www.atribuna.com.br/noticias/noticiasdetalhe/santos/parte-da-fachada-de-duas-casas-cai-e-destroem-carro-em-santos/? cHash $=570$ da76b270c94859c301080eb78b463>. Acesso em: 23 mai. 2017.

MUSEU Pelé é inaugurado neste domingo. Diário do Litoral, Santos, 13 jun. 2014. Disponível em: $<$ http://www.diariodolitoral.com.br/cotidiano/museu-pele-e-inaugurado-nestedomingo/36172/>. Acesso em: 3 maio 2018.

NAHOUM, B. Los Antecedentes: de la autoconstrucción individual a las cooperativas pioneras. In: (Org.) Las cooperativas de vivienda por ayuda mutua uruguayas: una historia con quince mil protagonistas. Sevilla/Montevideo: Junta de Andalucia/Intendencia Municipal, 1999.

NAIME, J. Política de habitação social no Brasil pós-2003: incentivos e barreiras estatais à produção associativa. In: LAGO, L. C. (Org.) Autogestão habitacional no Brasil: utopias e contradições. Rio de Janeiro: Letra Capital - Observatório das Metrópoles, 2012.

NASCIMENTO, F. B. Habitação como patrimônio: a preservação dos conjuntos residenciais 
modernos. Revista CPC, São Paulo, n. 4, p. 23-29, maio/out. 2007.

NASCIMENTO, F. B. Patrimônio cultural e escrita da história: a hipótese do documento na prática do Iphan nos anos 1980. Anais do Museu Paulista: História e Cultura Material, v. 24, n. 3, set./dez. 2016. Disponível em: <http://www.scielo.br/scielo.php?

script $=$ sci_arttext\&pid=S0101-47142016000300121\&lng=pt\&tlng=pt $>$. Acesso em: 7 mar. 2017.

NASCIMENTO, N. O.; BERTRAND-KRAJEWSKI, J. L.; BRITTO, A. L. Águas urbanas e urbanismo na passagem do século XIX ao XX: o trabalho de Saturnino de Brito. Revista da UFMG, Belo Horizonte, v. 20, n. 1, p. 102-133, jan./jul. 2013.

NUNES, R. E. S. S. Socioeconomia solidária. In: PINTAUDI, S. M. (org.) Economia solidária: um setor em desenvolvimento. São Paulo: Prefeitura de Rio Claro, 2002. p. 59-67.

PAGANI, E. A. O direito de propriedade e o direito à moradia: um diálogo comparativo entre o direito de propriedade urbana imóvel e o direito à moradia. Porto Alegre: EDIPUCRS, 2009.

PEABIRU. Disponível em: <http://www.peabirutca.org.br/>. Acesso em: 14 abr. 2017.

PEDON, N. R. Geografia e Movimentos Sociais: dos primeiros estudos à abordagem socioterritorial. São Paulo: Editora Unesp, 2013.

PREFEITURA entrega Estação Ferroviária do Valongo. Perspectiva, Santos, jan. 2004, Metrópole. Disponível em: <http://www.novomilenio.inf.br/real/ed127r.htm>. Acesso em: 22 mar. 2017.

PREFEITURA DE SANTOS. Censo dos moradores de cortiços: Vila Nova e Paquetá. Santos, 2003.

PREFEITURA DE SANTOS. Alegra Centro Habitação vai recuperar moradias e atrair empreendimentos. 2 ago. 2013. Disponível em: <http://www.santos.sp.gov.br/? $\mathrm{q}=$ noticia/22223/alegra-centro-habita-o-vai-recuperar-moradias-e-atrair-empreendimentos $>$. Acesso em: 3 de jul. de 2015 .

PREFEITURA DE SANTOS. Prefeitura projeta ampla reforma no Alegra Centro. Santos, 16 ago. 2013. Disponível em: <http://www.santos.sp.gov.br/portalpms/?

$\mathrm{q}=$ noticia/80324/prefeitura-projeta-ampla-reforma-no-alegra-centro $>$. Acesso em: 3 maio 2018.

PREFEITURA DE SANTOS. Obras do entorno do Museu Pelé seguem em ritmo acelerado. Santos, 15 abr. 2014. Disponível em: <http://www.santos.sp.gov.br/?q=noticia/698968/obrasdo-entorno-do-museu-pel-seguem-em-ritmo-acelerado>. Acesso em: 3 maio 2018.

PREFEITURA DE SANTOS. Exposição 'Muretas da cidade' será instalada na Pinacoteca. Santos, 2 mar. 2016. Disponível em: $<$ http://www.santos.sp.gov.br/?q=content/exposicaomuretas-na-cidade-sera-instalada-na-pinacoteca>. Acesso em: 20 jul. 2016. 
PREFEITURA DE SANTOS. Fachada externa do Teatro Coliseu passa por inspeção para elaboração de laudo. Santos, 8 nov. 2016. Disponível em: <http://www.santos.sp.gov.br/? $\mathrm{q}=$ content/fachada-externa-do-teatro-coliseu-passa-por-inspecao-para-elaboracao-de-laudo $>$. Acesso em: 3 maio 2018.

REOLOM. M. Ministério Público pede restauração de vila centenária na zona leste. O Estado de S. Paulo. 08 abr. 2015. Disponível em: <https://saopaulo.estadao.com.br/noticias/geral,ministerio-publico-pede-restauracao-de-vila-centenariana-zona-leste,1665581>. Acesso em: 19 fev. 2016.

RIZEK, C. S. Um balanço de pesquisa: 10 anos na zona leste e um social reconfigurado. Revista Cidades, São Paulo, v. 13, n. 22, p. 94-140, 2016. Disponível em: < http://revista.fct.unesp.br/index.php/revistacidades/article/view/5375/3958 >. Acesso em: 15 mai. 2017.

RIZEK, C. S.; CARVALHO, C. S.; CAMARGO, C. M. Política social, gestão e negócio na produção das cidades: o programa Minha Casa Minha Vida "entidades". Caderno CRH, Salvador, v. 27, n. 72, set./dez. 2014. Disponível em: <http://www.scielo.br/scielo.php? script=sci_arttext\&pid=S0103-49792014000300006 $>$. Acesso em: 3 mai. 2017.

RODRIGUES, A. M. Movimentos populares urbanos e as lutas contra a segregação socioespacial. In: MARTINS, C. A. A.; SILVA, S. M. V.; MARTINS, S. F. (Org.) Quintas Urbanas: conversas sobre a cidade e o urbano. $2^{\mathrm{a}}$ ed., Rio Grande-RS: NAU-FURG, 2010, p. 87-107.

ROYER, L. O. Política habitacional no Estado de São Paulo: Estudo sobre a Companhia de Desenvolvimento Urbano do Estado de São Paulo, CDHU. 2002. 209 p. Dissertação (Mestrado em Arquitetura) - Faculdade de Arquitetura e Urbanismo, Universidade de São Paulo, São Paulo, 2002.

SAMPAIO, A. R. Centros históricos de Bolonha e do Porto: lições de reabilitação urbana para o debate contemporâneo. Revista CPC, São Paulo, n. 23, p. 40-64, jan./jul. 2017. Disponível em: <https://www.revistas.usp.br/cpc/article/view/128187>. Acesso em: 15 jan. 2018.

SÃO PAULO (Estado). Secretaria da Habitação. CDHU. Relatório-Geral do Programa de Atuação em Cortiços. Maio 2012. Disponível em: $<$ http://www.cdhu.sp.gov.br/download/manual/RelatorioGeralProgramaCorticos.pdf $>$. Acesso em: 2 nov. 2016.

SANTOS, A. R. O Centro de Santos: intervenções, legislação e projetos. 2008. 144 p.

Dissertação (Mestrado em Arquitetura) - Faculdade de Arquitetura e Urbanismo, Universidade de São Paulo, São Paulo, 2008.

SANTOS (Prefeitura Municipal). Lei $\mathrm{n}^{\mathrm{o}}$ 3.529, de 16 de abril de 1968. Institui o Plano Diretor Físico do Município de Santos, suas normas ordenadoras e disciplinadoras. Diário Oficial de Santos, Santos, 27 abr. 1968.

SANTOS (Prefeitura Municipal). Plano Diretor de Desenvolvimento Integrado de Santos. 98 
p. Santos: Prodesan, 1976.

SANTOS (Prefeitura Municipal). Lei Complementar $n^{0}$ 53, de 15 de maio de 1992. Dispõe sobre a criação de Zonas Especiais de Interesse Social - ZEIS, estabelece normas para a implantação de Empreendimentos Habitacionais de Interesse Social - EHIS. Diário Oficial de Santos, Santos, 18 mai. de 1992.

SANTOS (Prefeitura Municipal). Lei Complementar $n^{0} 311$, de 23 de novembro de 1998. Institui o plano diretor de desenvolvimento e expansão urbana do Município de Santos.

Diário Oficial de Santos, Santos, 24 nov. de 1998

SANTOS (Prefeitura Municipal). Lei Complementar no 312, de 23 de novembro de 1998. Disciplina o ordenamento do uso e da ocupação do solo na área insular do Município de Santos. Diário Oficial de Santos, Santos, 24 nov. de 1998

SANTOS (Prefeitura Municipal). Lei Complementar $n^{\circ} 470$, de 5 de fevereiro de 2003. Cria O Programa de Revitalização e Desenvolvimento da Região Central Histórica de Santos Alegra Centro. Diário Oficial de Santos, Santos, 6 fev. 2003.

SANTOS (Prefeitura Municipal). Lei Complementar $n^{\circ}$ 526, de 17 de março de 2005. Altera o Lei Complementar $n^{\circ} 470$, de 5 de fevereiro de 2003. Diário Oficial de Santos, Santos, 18 mar. 2005.

SANTOS (Prefeitura Municipal). Lei Complementar $n^{\circ}$ 688, de 29 de julho de 2010. Cria O Programa de Reabilitação do uso residencial na Região Central Histórica de Santos - Alegra Centro - Habitação. Diário Oficial de Santos, Santos, 30 jul. de 2010.

SANTOS (Prefeitura Municipal). Lei Complementar $n^{\circ}$ 640, de 18 de novembro de 2008. Altera dispositivos da Lei Complementar $n^{\circ} 470$, de 5 de fevereiro de 2003, da Lei n. ${ }^{\circ}$ 634, de 28 de setembro de 1989, e dá outras providências. Diário Oficial de Santos, Santos, 19 nov. 2008.

SANTOS (Prefeitura Municipal). Lei Complementar $n^{\circ}$ 646, de 30 de dezembro de 2008. Altera o Anexo I da Lei Complementar no 53, de 15 de maio de 1992. Diário Oficial de Santos, Santos, 31 dez. de 2008.

SANTOS (Prefeitura Municipal). Lei Municipal no 2678, de 28 de dezembro de 2009. Autoriza o poder executivo a celebrar convênio com a companhia docas do estado de São Paulo - Codesp, com interveniência da secretaria especial de portos da presidência da república - sep/ pr, visando à implementação conjunta do plano de revitalização de áreas portuárias e integração com áreas urbanas, situadas no Valongo. Diário Oficial de Santos, Santos, 29 dez. de 2009.

SANTOS (Prefeitura Municipal). Lei Complementar $n^{\circ}$ 821, de 27 de dezembro de 2013. Institui o plano diretor de desenvolvimento e expansão urbana do Município de Santos.

Diário Oficial de Santos, Santos, 28 dez. de 2013.

SANTOS (Prefeitura Municipal). Escritório Técnico Alegra Centro. Alegra Centro. 
Disponível em: $<$ http://www.santos.sp.gov.br/?q=projeto/alegra-centro $>$. Acesso em: 3 mai. 2018.

SÃO PAULO (Prefeitura Municipal). Lei ${ }^{\circ} 10.928$, de 8 de janeiro de 1991. Regulamenta o inciso II do artigo 148 combinado com o inciso V do artigo 149 da L.O.M., dispõe sobre as condições de habitação dos cortiços. Diário Oficial de São Paulo, São Paulo, 9 de jan. de 1991.

SCIFONI, S. O Patrimônio como negócio. In: CARLOS, A. F. A.; VOLOCHKO, D; ALVAREZ, I. P. (Org.) A cidade como negócio. São Paulo: Contexto, 2015. p. 209-228.

SEABRA, O. C. L. A muralha que cerca o mar: uma modalidade de uso do solo urbano. 1979. 122 p. Dissertação (Mestrado em Geografia) - Faculdade de Filosofia, Letras e Ciências Humanas, Universidade de São Paulo, São Paulo, 1979.

SESC SÃO PAULO. Encontro de Culturas. São Paulo, 30 nov. 2012. Disponível em: $<$ https://www.sescsp.org.br/online/artigo/6487_ENCONTRO+DE+CULTURAS $>$. Acesso em: 23 nov. 2017.

SIQUEIRA, F. Santos cria $1^{\text {a }}$ república para idosos. Folha de S. Paulo, São Paulo, 29 set. 1996. Disponível em: <http://www1.folha.uol.com.br/fsp/1996/9/29/cotidiano/12.html>. Acesso em: 15 set. 2017.

SMITH, N. The new urban frontier: gentrification and the revanchist city. London: Routledge, 1996.

SMITH, N. Gentrificação, a fronteira e a reestruturação do espaço urbano. GeoUSP - Espaço e Tempo, São Paulo, n. 21, p. 15-31, 2007.

SOARES, W. Sem-teto e professores protestam em frente ao Palácio dos Bandeirantes. G1/São Paulo. São Paulo, 10 nov. 2015. Disponível em: <http://g1.globo.com/saopaulo/noticia/2015/11/sem-teto-protestam-por-moradia-em-frente-ao-palacio-dosbandeirantes.html>. Acesso em: 10 fev. 2018.

SOUZA, C. D. C. Santos e o processo de requalificação de áreas portuárias sobre a perspectiva do planejamento urbano. 2012. 202 p. Tese (Doutorado em Arquitetura e Urbanismo) - Faculdade de Arquitetura e Urbanismo, Universidade de São Paulo, São Paulo, 2012.

SOUZA, M. L. de. Mudar a Cidade: uma introdução crítica ao planejamento e à gestão urbanos. Rio de Janeiro: Bertrand Brasil, 2002.

SOUZA, M. L. de. Planejamento urbano e ativismos sociais. São Paulo: UNESP, 2004.

TEATRO Coliseu é interditado pela Prefeitura de Santos. TV Tribuna/G1, Santos, 5 abr. 2013. Disponível em: < http://g1.globo.com/sp/santos-regiao/noticia/2013/04/teatro-coliseu-einterditado-pela-prefeitura-de-santos.html>. Acesso em: 22 mar. 2017. 
TEATRO Guarany, em Santos, completa 130 anos de inauguração. TV Tribuna/G1, Santos, 7 dez. 2012. Disponível em: <http://g1.globo.com/sp/santos-regiao/noticia/2012/12/teatroguarany-em-santos-completa-130-anos-de-inauguracao.html> Acesso em: 22 mar. 2017.

TODOROV, T. Los abusos de la memoria. Barcelona: Ediciones Paidós Ibérica, 2000.

TOM ZÉ. Senhor Cidadão. In: Tom Zé. São Paulo: Continental, 1972. 1 disco (32,20 min.): 33 1/3 rpm, estéreo. Lado A, faixa 6.

UNIÃO NACIONAL POR MORADIA POPULAR - UNMP. Programa Crédito Solidário. Disponível em: <http://www.unmp.org.br/index.php? option $=$ com_content\&view $=$ article $\&$ id $=189$ :programa-credito-solidario\&Itemid $=98>$. Acesso em 05 mai. 2018.

URIARTE, U. M. Intervenções recentes em Centros Históricos: as políticas de recuperação dos Centros Históricos de Salvador, Lima e Quito. Cadernos do CEAS, Salvador, n. 208, p. 73-92, nov./dez. 2003.

URIARTE, U. M. O lugar da História no consumo do chamado patrimônio histórico. Revista Interseções, Rio de Janeiro, v. 14, n. 1, p. 7-24, jun. 2012.

URIARTE, U. M. Por trás das fachadas coloridas. Etnografias nos "novos" Bairro do Recife (Pernambuco) e Pelourinho (Bahia). Ponto.Urbe (USP), v. 7 ano 4, 2010. Disponível em: $<$ https://journals.openedition.org/pontourbe/1654>. Acesso em: 05 mai. 2018.

VALLÉS, R. Reciclajes. In: NAHOUM, B. (Org.) Las cooperativas de vivienda por ayuda mutua uruguayas: una historia con quince mil protagonistas. Sevilla/Montevideo: Junta de Andalucia/Intendencia Municipal, 1999.

VILLAÇA, F. Espaço Intra-urbano no Brasil. São Paulo: Studio Nobel, 2001.

VOLOCHKO, D. A moradia como negócio e a valorização do espaço urbano metropolitano. In: CARLOS, A. F. A.; VOLOCHKO, D.; ALVAREZ, I. P. (Org.) A cidade como negócio. São Paulo: Contexto, 2015.

WILlianS, S. Surgimento dos teatros em Santos. Portal Memória de Santos. Fundação Arquivo e Memória de Santos, Santos. Disponível em: $<$ http://www.memoriadesantos.com.br/post/surgimento-dos-teatros-em-santos-102/>. Acesso em: 14 mar. 2017. 
ANEXO I: Cortiços nos bairros centrais de Santos - Prefeitura Municipal de Santos - 2010.

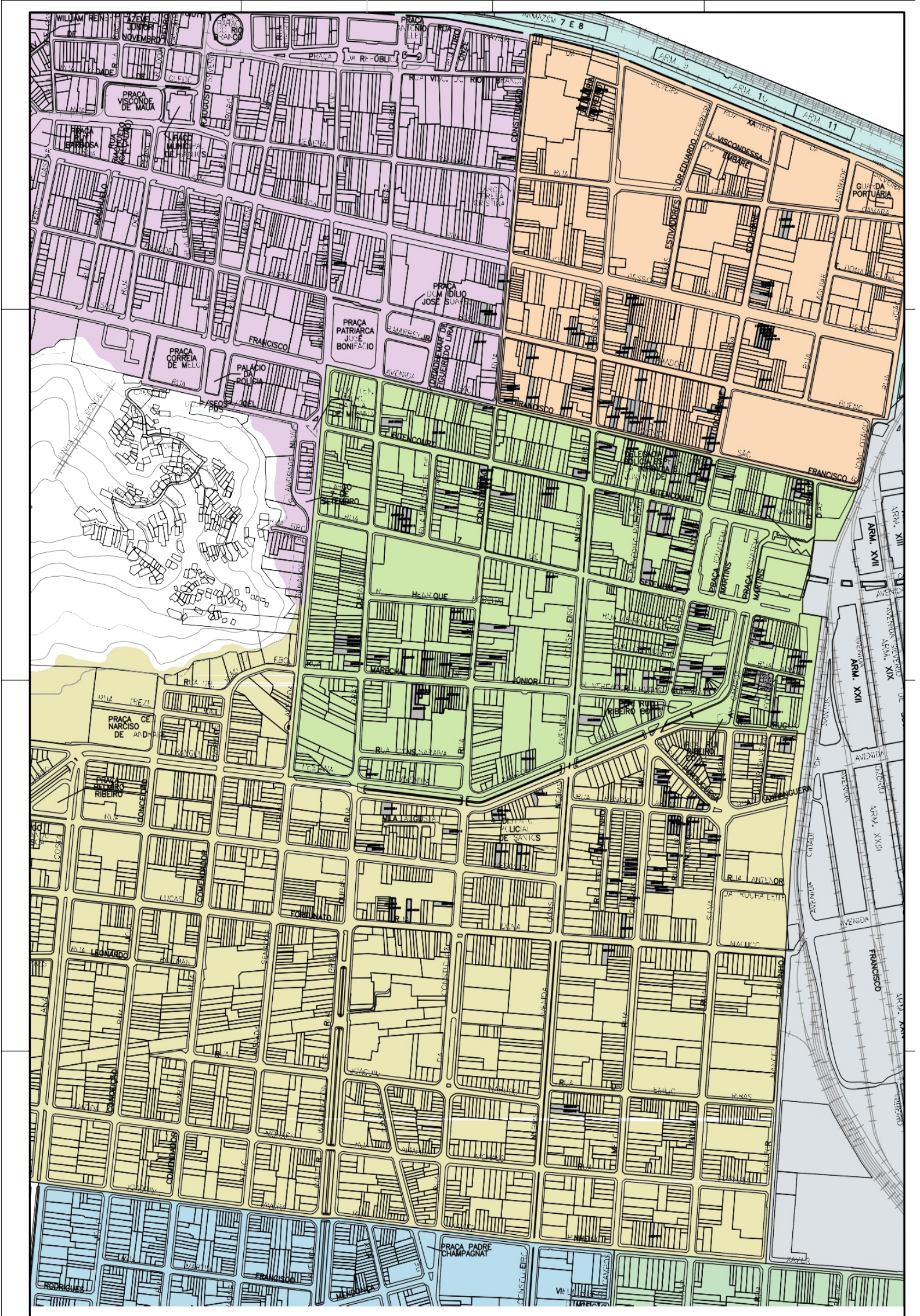


ANEXO II: Projeto da creche da ACC - Instituto Elos.
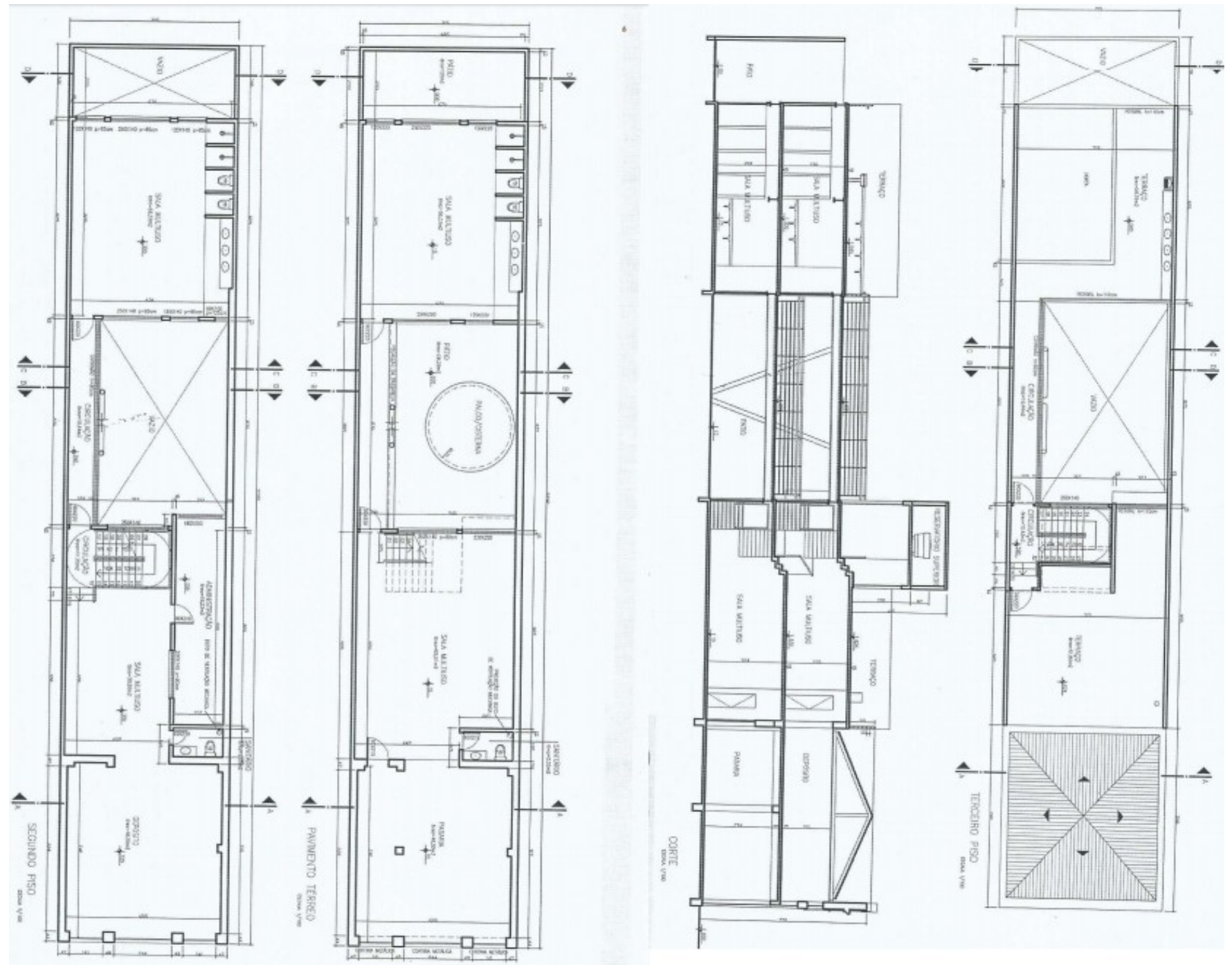